\author{
Universidade de São Paulo \\ Faculdade de Filosofia, Letras e Ciências Humanas \\ Departamento de Filosofia \\ Programa de Pós-Graduação em Filosofia
}

Ronaldo Manzi Filho

\title{
Em torno do corpo próprio e sua imagem
}




\section{Ronaldo Manzi Filho}

\section{Em torno do corpo próprio e sua imagem}

Dissertação apresentada ao Departamento de Filosofia da Faculdade de Filosofia, Letras e Ciências Humanas da Universidade de São Paulo, sob a orientação do Prof. Dr. Vladimir Pinheiro Safatle, como exigência parcial para a obtenção do título de Mestre em Filosofia 
A meus pais. 
Gostaria de agradecer ao Prof. Vladimir Safatle pela preciosa orientação que recebi no desenvolvimento deste trabalho. Seus apontamentos foram fundamentais, igualmente a autonomia que me foi concedida para tecer problemas.

Agredeço aos Profs. Franklin Leopoldo e Silva (que já havia me indicado caminhos na minha qualificação) e Luiz Damon Santos Moutinho, por aceitarem participar da minha banca. Também ao CNPq, por ter fornecido dois anos de bolsa para minha pesquisa.

Agradeço, por fim, ao Tiago Oliveira, pela sua presença constante durante a elaboração deste trabalho, assim como ao Leandro Cardim, pelo diálogo sempre enriquecedor que mantivemos nestes últimos anos. 
Um cão, porque vive, É agudo.

O que vive

Não entorpece.

$\mathrm{O}$ que vive fere.

O homem,

Porque vive,

Choca com o que vive.

Viver

É ir entre o que vive.

O que vive Incomoda de vida

O silêncio, o sono, o corpo

Que sonhou cortar-se

Roupas de nuvem.

$\mathrm{O}$ que vive choca,

Tem dentes, arestas, é espesso.

O que vive é espesso

Como um cão, um homem,

Como esse rio.

Como todo o real

É espesso.

(João Cabral de Melo Neto) 


\section{Resumo:}

MANZI Filho, R. Em torno do corpo próprio e sua imagem. 2007. 189 f. Dissertação (Mestrado) - Faculdade de Filosofia, Letras e Ciências Humanas. Departamento de Filosofia, Universidade de São Paulo, São Paulo, 2007.

Meu objetivo nesta pesquisa é entender a noção de “corpo próprio” pensada por MerleauPonty nas suas primeiras obras. Trata-se de uma noção “cara” ao filósofo, levando-o a questionar e a dialogar tanto com a filosofia quanto com a psicologia, fisiologia e a psicanálise de sua época. De qualquer modo, é a partir da descrição deste conceito que veremos como o filósofo pôde sugerir uma subjetividade sem plena determinação de si, que nos remete a um sujeito corporal em relação com o mundo, com o outro e consigo mesmo. Desta descrição, irei seguir um desdobramento específico deste conceito: a "imagem corporal”. Pretendo mostrar como a interpretação merleau-pontyana, nos cursos de Sorbonne, do “estádio do espelho” (proposto por Lacan), pode “ampliar” o questionamento em torno da problemática da relação com o outro.

Palavras-chave: Corpo próprio, Imagem corporal, Poder corporal 


\section{Abstract:}

MANZI Filho, R. Around the own body and its bodily image. 2007. 189 p. Thesis (Master Degree) - Faculdade de Filosofia, Letras e Ciências Humanas. Departamento de Filosofia, Universidade de São Paulo, São Paulo, 2007.

My purpose on this research is the understanding of the notion of the "own-body" thought by Merleau-Ponty on his first papers. It deals with a costly notion for the philosopher, leading him to question and to dialog both with philosophy and psychology as well as with physiology and psychoanalysis of his time. Neverthless, from the description of this concept, we will understand how the philosopher could sugest a subjectivity without a broad determination of itself, that guides us towards a bodily subject in relation with the world, the other and itself. From this description, I will follow a particular development of this concept: the "bodily image”. I intend to show how Merleau-Ponty's interpretation, in Sorbonne's courses, of the "mirror stage" (suggested by Lacan), could "amplify" the question around the matter of the relationship with the other.

Keywords: own body, bodily image, bodily power 


\section{Lista de abreviações}

AM - Autour du Marxisme in Sens et non-Sens

C-Causeries - 1948

CnNP - Le Cinema et la Nouvelle Psychologie in Sens et non-Sens

CR - Christianisme et Ressentiment in Parcours (1935-1951)

DtCz - Le Doute de Cézanne in Sens et non-Sens

EtAv - Etre et Avoir in Parcours (1935-1951)

EH - L'Existentialisme chez Hegel in Sens et Non-Sens

GL - La Guerre a eu Lieu in Sens et Non-Sens

HA - L'Homme et L'Adversité in Signes

HT - Humanisme et Terreur

HNN - Husserl el la Notion de Nature in Parcours Deux(1951-1961)

IP - L'Institution, la Passivité - Notes de Cours au Collège de France (1954-1955)

MH - Le Métaphysique dans l'Homme in Sens et non-Sens

MPM - Le Mouvement Philosophique Moderne in Parcours (1935-1951)

N - La Nature - Notes de Cours du Collège de France

NM - Note sur Machiavel in Signes

NC - Notes de Cours (1959-1961)

PnP - Partout et nulle part in Éloge

$\mathrm{PhP}$ - Phénoménologie de la Perception

PE - La Philosophie de l'Existence in Parcours Deux (1951-1961)

PO - La Philosophe et son Ombre in Signes

PS - Le Philosophie et la Sociologie in Signes

PP - Le Primat de la Perception - et sés Conséquences Philosophiques

QE - La Querelle de l'Existentialisme in Sens et Non-Sens 
RAE - Les Relations avec Autrui chez l'Enfant in Pacours (1935-1951

RC - Résumés de cours - Collège de France (1952-1960)

ShPh - Les Sciences de l'Homme et la Phénoménologie in Parcours Deux (1951-1961)

Sorb - Merleau-Ponty à la Sorbonne - résumé de cours (1949-1952)

SC - La Structure du Comportement

TT - Titres et Travaux. Projet d'Enseignement in Parcours deux (1951-1961)

UAC - L'Union de l'Âme et du Corps

VI - Le Visible et l'Invisible 


\section{Sumário}

\section{Introdução 11}

\section{Primeiro capítulo - O corpo em perspectiva}

1) O mundo vivido e o pré-objetivo 18

2) $\mathrm{O}$ campo perceptivo 25

3) Questões em torno da perspetiva espacial e temporal do corpo 32

4) O sujeito de percepção 41

\section{Segundo capítulo - Ser no mundo}

1) Um modo de relação com o mundo: uma coisa diante de outra 44

2) Um comércio originário 46

3) Um "poder" de situar-se no possível: a diferença entre o comportamento humano e o comportamento animal 50

4) Conduta possível e conduta concreta: o normal e o patológico 53

5) Mudança qualitativa do comportamento 57

6) Uma atividade orientada 62

7) As motivações 65

8) Estar aberto ao mundo... 69

\section{Terceiro capítulo - A consciência enquanto “eu posso”}

1) Um modo original do corpo se relacionar com o mundo: um novo estatuto do "saber" 73

2) A imitação infantil 75

3) O hábito corporal 78

4) O corpo expressivo 81

5) O corpo libidinal 86

6) A consciência perceptiva operando num modo "indeterminado" 100 
Quarto capítulo - A consciência da unidade corporal e a consciência de si

1) A consciência da unidade corporal 104

2) A quase presença do corpo - o membro fantasma 109

3) Porque não dizer de uma imagem corporal? 118

4) Ilusão e percepção — uma fé no mundo 122

5) A consciência de si 126

6) O corpo com posse do tempo 132

Quinto capítulo - A imagem corporal em operação no esquema corporal

1) Percebendo o comportamento do outro 136

2) Um sincretismo da criança com o outro 141

3) Um certo episódio do desenvolvimento infantil 146

4) $O$ poder formativo da imagem 149

5) Um poder também alienante - um espetáculo especular? 155

6) Esboço de um conflito na relação com o outro 158

7) Um deslocamento sutil 165

8) Breves apontamentos: uma "situação comum" 170

Conclusão — Em torno do corpo próprio e sua imagem... 178

\section{Bibliografia 181}




\section{Introdução}

“Como sair de um idealismo sem cair num ingênuo realismo?” (MPM, p. 66) ${ }^{1}$ Talvez esta seja a melhor questão para entendermos o esforço merleau-pontyano de buscar quase que obsessivamente um modo de repensar a subjetividade. Mas este problema certamente não é um problema isolado e está inserido numa problemática maior do pensamento de MerleauPonty: de pensar a relação da consciência e da natureza (SC, p. 1). Não é por menos que ela trazia consigo a necessidade de repensar em primazia o estatuto ontológico do mundo assim como sua relação com a subjetividade. No fundo, esta tarefa indicava uma necessidade da racionalidade, aos seus olhos, de “descer à terra” (PP, p. 43), ao negar um suposto sujeito absoluto, fora do tempo, que constituiria o mundo de uma vez por todas e ao negar também um sujeito que simplesmente aceitasse uma “coincidência” da consciência com o mundo sem questionar seu sentido (em prol de um mundo em si). De qualquer modo, o problema parece ter uma raiz que Merleau-Ponty não faz questão de esconder: o cogito cartesiano, este "ser cultural” inaugurado tão recentemente, nos termos do filósofo (PhP, p. 423), e que parece ternos adestrado (HUSSERL, 2004, §9).

Este problema, é certo, não é estranho ao pensamento do século XX (basta darmo-nos conta da força do lema vers le concret, de Jean Wahl (1932), na França, contra a filosofia de inspiração kantiana, após a década de 30 (DESCOMBES, 1993, pp. 28-36)). Mas algo me parece peculiar na pretensão de Merleau-Ponty, principalmente na época em que tomava esta questão como um problema: seria, sim, possível sair de um idealismo sem cair num realismo ingênuo ao buscar descrever a consciência num contato de si a si mesma, na medida em que

\footnotetext{
${ }^{1}$ Segundo Merleau-Ponty, este era seu esforço desde 1936, quando estava escrevendo seus projetos de trabalho.
} 
ela é aderente ao mundo e o transcende ao mesmo tempo, mas tomando esta aderência e esta transcendência como um problema e como um drama que jamais cessa de se questionar.

Esta questão trazia assim a necessidade de repensarmos a Racionalidade, depois dos problemas trazidos pela fenomenologia de Husserl, principalmente quando ele colocou em pauta um Eu que não é da ordem do "eu penso que" que é solidário a um mundo vivido. Há assim um caminho para Merleau-Ponty: desde que Husserl afirmou esta Lebenswelt, retomando uma certa "produtividade" de sentidos no mundo, como "berço de todas as significações”, “sentido de todos os sentidos”, “de todos os pensamentos” (PhP, p. 492). Se o mundo é o berço das significações, é porque o próprio mundo tem um sentido latente que um suposto sujeito absoluto tomaria como seu ou que a consciência ingênua acreditaria ser algo tomado ao “acaso”, numa associação fortuita de sentidos na própria consciência.

Para Merleau-Ponty, isto é ao mesmo tempo uma “reabilitação” de um sujeito em contato com este mundo vivido. Seria assim necessário descrever que o Eu não é uma instância, assim como professava quase toda tradição pós-cartesiana: não mais um sujeito transparente a si mesmo, mas um sujeito que não se reconheceria racionalmente em todas as suas ações. Há uma esfera de ação abaixo do domínio do “eu penso que”, descrita em termos de uma relação vivida e não-pensada. Isto leva Barbaras (2005b, p. 209), por exemplo, a afirmar que o objetivo de Merleau-Ponty é clarificar o estatuto do sujeito como de prioridade da tese da Weltthesis: o sujeito é um sujeito de um mundo vivido — “o sujeito do mundo da vida é precisamente a vida”.

Seja como for, isto significa buscar, entre outras coisas, algo estranho ao primado do eu, desta instância que se fundamenta num princípio de identidade. É como se houvesse uma possibilidade de se pensar no irrefletido, aquilo que está fora da reflexão, no sentido mais significativo deste termo (como algo que reflete a si mesmo, como um espelho de si). Este irrefletido, que para Merleau-Ponty fundamenta e é o verdadeiro solo da reflexão, teria uma 
lógica própria e mesmo uma lógica que poderia ser descrita na experiência que temos no mundo. Tal possibilidade é o que Merleau-Ponty tinha em mente ao tentar entender, desde sua primeira obra, La Structure du Comportement, a relação da consciência e a natureza. Seria possível descrever o comportamento humano sob o irrefletido da sua conduta. Trata-se de buscar no fundo uma relação direta com o mundo. Aliás, desde 1935, Scheler já lhe inspirava este problema ao dizer de um “comércio direto com o mundo e com as coisas” (CR, p. 23), e a Phénoménologie de la Perception é a prova maior desta busca de uma relação primordial com o mundo. Não é por menos que o filósofo afirmará um pouco depois que “não há racionalidade possível a não ser naquela que aceita o quadro irracional da vida, da percepção” (Sorb, p. 231).

No limite, o que Merleau-Ponty protesta do pensamento objetivista é o fato de se pensar o homem, seu comportamento, seus vínculos sociais, intersubjetivos, a partir de uma visão de "sobrevôo", se afastando da relação en train de (do gerúndio da ação), em prol de um mundo totalmente determinável. É por isso que a filosofia seria sempre (e deveria sempre ser) uma ruptura com o objetivismo (PS, p. 141).

É como se todas as coisas devessem ser reduzidas ao que é determinável, sendo “o resto” algo necessariamente excluído, “jogado para fora” do pensamento objetivo. Ora, é exatamente este “fora” o primordial a Merleau-Ponty. É este indeterminado o que realmente está em jogo para o filósofo:

(...) o centro da filosofia não é mais uma subjetividade transcendental autônoma, situada em toda parte e parte nenhuma; ele se encontra no começo perpétuo da reflexão, a este ponto onde uma vida individual se põe a refletir sobre ela mesma. A reflexão só é verdadeiramente uma reflexão se ela não se arrebata para fora dela mesma, se se conhece como reflexão de um irrefletido (PhP, pp. 75-76).

Isto significa buscar uma subjetividade que seja solidária a esta experiência irrefletida, à consciência em contato direto com o mundo mas sem ter plena determinação de si. Há um outro sujeito abaixo do "eu penso que” que, aos olhos do filósofo, daria sentido a esta articulação: é o corpo enquanto um sistema de funções anônimas que envolvem toda fixação 
particular num projeto geral (PhP, p. 294). Para Merleau-Ponty, isto é o mesmo que descrever a posição subjetiva como um sujeito corporal. Tal é imprescindível ao filósofo, uma vez que “eu me engajo com meu corpo entre as coisas; elas coexistem comigo como sujeito encarnado; e esta vida nas coisas não tem nada em comum com a construção dos objetos científicos” (PhP, p. 216).

A constatação de Merleau-Ponty é simples: “é-me tão essencial ter um corpo como é essencial ao futuro ser futuro de um certo presente... Mais ainda, não me é essencial apenas ter um corpo, mas ter este corpo” (PhP, p. 493). Mas disto há conseqüências não tão óbvias. Uma delas: “(...) a existência efetiva do meu corpo é indispensável à de minha consciência” (PhP, p. 493). Ou seja, a experiência vivida contrariaria em larga medida a tradição cartesiana, que colocava o corpo como uma exterioridade, uma soma de partes sem interior, e a alma, uma interioridade, distante do mundo mas totalmente presente a si. O que o filósofo pretende aqui é desarticular primeiramente a escolha entre uma existência enquanto coisa e na existência enquanto consciência (um exterior sem interior e um interior sem exterior) (PhP, p. 231).

Este é um problema, crucial a Merleau-Ponty, que nos leva a pensar num fato paradoxal: “a existência do corpo humano” (UCA, p.13, grifo meu). Ora, Descartes apontava também uma opacidade concreta, seja na fome, na dor, nos sentimentos, algo que podemos notar em seu “julgamento”: “(...) eu não posso de nenhum modo duvidar que há nisto alguma verdade” (DESCARTES, 1950, p.153). Nada mais ambíguo: uma outra forma de verdade que parece escapar da verdade do puro entendimento? O mesmo Descartes que "preenche" o mundo com seus dois "habitantes" (a res extensa e a res cogitans) apontava, na Méditation Sixième, um fato determinante ao pensamento filosófico merleau-pontyano: uma certa “mistura”, “confusão”, entre o corpo e o espírito (DESCARTES, 1950, p.153). Aliás, até mesmo determinante à fenomenologia francesa: 
uma boa parte da filosofia fenomenológica ou existencial consiste em se admirar desta inerência do eu ao mundo e do eu ao outro, a nos descrever este paradoxo e esta confusão [confusão que Descartes apontava entre o corpo e a alma], a fazer ver o lugar do sujeito e do mundo, do sujeito e os outros, no lugar de explicar, como faziam os clássicos, recorrendo a algum espírito absoluto (CnNP, p. 74).

Uma confusão que indicava uma "cifra” que caracterizou de vários modos a fenomenologia desta época, segundo Aubert (2005, pp. 28-29), que chega a dizer que esta “mistura” aparece “(...) conjugada sob todos os modos, generalizado à mistura do interior e o exterior, da atividade e da passividade, mistura do aqui e do lá na profundidade, do antes e do depois no movimento, mistura do eu e do outro, do eu e do mundo, até uma mistura entre o ser e o nada”.

Esta figura de “mistura” aparece em Merleau-Ponty em vários momentos sob o signo de “ambigüidade”, de "paradoxo”. Uma em especial me interessa neste trabalho: aquela ambigüidade entre a consciência e o mundo (CnNP, p. 75). Um paradoxo que poderia se resumir nesta passagem: “o corpo é impensável sem a consciência, pois existe uma intencionalidade corporal, e a consciência é impensável sem o corpo, pois a presença é corporal” (UCA, p. 86). Trata-se de superar uma contradição de toda teoria da percepção segundo o filósofo: “de uma parte, a consciência está em função do corpo, ela é então um evento 'interior' dependente de alguns eventos exteriores; de outra parte, estes eventos exteriores eles-mesmos só são conhecidos pela consciência” (SC, p. 232). Mas, como teremos oportunidade de ver, o filósofo buscará superar esta contradição com uma ambigüidade: um entrelaçamento, uma zona conjugada que permite a Merleau-Ponty buscar uma subjetividade corporal que está num contato direto com o mundo.

É certo que isto tem para o filósofo um sentido muito claro: somos seres “encarnados”, estamos aderidos ao mundo, somos um être au monde (onde a existência se realiza ( $\mathrm{PhP}, \mathrm{p}$. 193)): “o corpo próprio está no mundo como o coração no organismo” (PhP, p. 235). Isto é, meu corpo é meu “veículo” no mundo (PhP, p. 66): “ser uma consciência ou antes, ser uma 
experiência, é comunicar interiormente com o mundo, o corpo e os outros, ser com eles, no lugar de ser ao lado deles” (PhP, p. 113).

De qualquer modo, salta aos olhos a noção de corpo próprio: é a partir da descrição deste corpo próprio que o filósofo pôde rearticular o irrefletido com uma subjetividade sem plena determinação de si. É por isto que meu primeiro objetivo neste trabalho é descrever esta noção apresentada nos primeiros trabalhos de Merleau-Ponty. Para tanto, começarei meu trabalho mostrando a necessidade de se pensar numa relação direta do sujeito com o mundo. Isto nos levará a entender por que o corpo próprio é como o sujeito de percepção.

Teremos que compreender também como a noção de corpo próprio nos leva a pensar numa subjetividade sem plena determinação de si, que nos remete a um sujeito corporal em relação com o mundo e consigo mesmo. Para evidenciar isto, irei descrever: o ser no mundo; o modo original do corpo se relacionar com o mundo; como o sujeito toma consciência de si. Farei isto no segundo, terceiro e quarto capítulo, respectivamente.

Aqueles que são familiarizados com a obra de Merleau-Ponty certamente irão estranhar a ausência de vários tópicos na minha dissertação, a brevidade em que trato alguns problemas profundos da fenomenologia, sem contar alguns saltos que dou, entre outras coisas. É bom ressaltar que não tenho aqui a pretensão de analisar ou de acompanhar tête-à-tête os pormenores que a Phénoménologie de la Perception nos traz, e muito menos os desdobramentos possíveis destes problemas. Dentre as diversas abordagens possíveis, tentarei circunscrever um ponto de vista restrito, é verdade, tomando como fio condutor uma análise em torno do corpo próprio, num desdobramento específico deste conceito. É por isso que, por fim, abordarei o problema da relação com outrem. É aí que aparecerá meu segundo objetivo neste trabalho: pensar o problema da imagem corporal. Tentarei mostrar como não é por acaso que este conceito não figurava ali na Phénoménologie de la Perception, mesmo baseando seus estudos sobre o "membro fantasma", em trabalhos como de Lhermitte 
(L'Image de Notre Corps). Mostrarei, entretanto, como a inserção da imagem corporal no esquema corporal nos levará a pensar numa mudança singular com a Phénoménologie de la Perception. Isto ficará mais claro principalmente ao analisarmos como a relação com o outro era apresentada nesta obra e como será apresentada a partir da interpretação merleau-pontyana do estádio do espelho, de Lacan. Como nos diz Martin Jay (1993, pp. 320-323), por exemplo, esta tomada do estádio do espelho por Merleau-Ponty não parece ser uma mera mudança de atitude frente à psicanálise, mas uma tentativa de pensar no problema "visual”, juntamente com o sentido da relação com o outro.

Penso que é pertinente pensarmos em torno do corpo próprio e sua imagem em Merleau-Ponty, principalmente nos seus primeiros trabalhos, porque, como tentarei apontar, isto nos leva a repensar a relação com o outro: trata-se de uma relação “meramente” descrita em termos de uma consciência perceptiva? Ou o imaginário, assim como dizia Lacan, por exemplo, também está em operação nesta relação para o filósofo? Qual seria o preço desta assunção? O que está em jogo aqui? 


\section{Primeiro capítulo - O corpo em perspectiva}

\section{1) O mundo vivido e o pré-objetivo}

Talvez todo leitor da obra merleau-pontyana estranhe, à primeira vista, como, dentre a pretensão do filósofo, tenhamos sempre que retomar questões que, aparentemente, estariam distantes dos problemas filosóficos. Salta aos olhos questões que estão no seio da psicologia e da fisiologia como, por exemplo, a descrição do comportamento ou da percepção.

Num primeiro momento, é certo que isto tem um sentido crítico à filosofia: mostrar que vários problemas que são aparentemente distantes do debate filosófico, como os campos empíricos do saber, forneceriam à filosofia uma capacidade fundamental de autocrítica. Na verdade, o retorno à Gestalttheorie, assim como à psicologia infantil e aos trabalhos de Goldstein, entre outros estudos, me parece uma estratégia do filósofo de buscar aquilo que a filosofia jamais poderia ter deixado de tomar contato: com os fatos (PhP, p. 498). Veremos como é imprescindível a Merleau-Ponty abrir um debate com os saberes empíricos, ou com aquilo que ele irá denominar de modo mais amplo como “não-filosofia” (UAC, p. 46), para analisar aquilo que nos é dado na experiência. A lição de um contemporâneo seu, como Canguilhem, encaixa muito bem aqui: “a filosofia é uma reflexão pela qual toda matéria estrangeira é boa, e diríamos facilmente que toda boa matéria deve ser estrangeira” (CANGUILHEM, 2002, p. 15, tradução modificado). Peillon (2004, p. 13), por exemplo, nos participa desta constatação:

nós estamos longe aqui desta piedosa e falsa imagem segundo a qual a filosofia de inspiração fenomenológica não teria por programa senão um retorno ao vivido imediato da consciência ingênua. É, 
ao contrário, numa configuração histórica bem determinada do saber positivo que elas formulam seu projeto erudito e encontram seu ato de nascimento ${ }^{1}$.

Um exemplo disto é o projeto de doutorado de Merleau-Ponty, no qual ele acusa muitos filósofos contemporâneos franceses ${ }^{2}$ de não levarem em conta os estudos da psicologia na determinação do “estatuto da percepção” (principalmente da Gestalttheorie), assim como a fenomenologia husserliana. Uma lição que, mais tarde, na Phénoménologie de la Perception, ficará evidente: a “nova psicologia” não só convergia com a problemática husserliana como apontava e ampliava uma formulação da nossa experiência em relação ao mundo (PhP, p. 62) ${ }^{3}$.

Mas este estranhamento também se dá por outro motivo. Este, mais importante a meu ver: para o filósofo, é preciso que a racionalidade "desça à terra” (PP, p. 43): toda filosofia que se pretenda transcendental deve se pôr entre parênteses, e realizar sua genealogia a partir da experiência efetiva (PhP, p. 255).

Não podemos deixar de notar como isto nos soa muito próximo do lema vers le concret, colocado em pauta por Jean Wahl (1932, passim) e tão difundido e repetido por Georges Politzer (1947, passim) e Gabriel Marcel (1935, passim), por exemplo. Lembremos que, em linhas largas, este tema é notável por pautar o retorno ao singular, à dramaticidade da

\footnotetext{
${ }^{1}$ Neste sentido, Peillon talvez tenha razão em aproximar Merleau-Ponty de Bachelard: "paradoxalmente, o ponto de partida da filosofia de Merleau-Ponty não seria diferente daquele que motivava, próximo à sua época, a de Gaston Bachelard, a saber, a constatação de um deslocamento crescente entre o estado de avanço das ciências e aquele da filosofia, e a vontade que resulta de pôr esta última na escola das primeiras” (2004, p. 13).

${ }^{2}$ Cita Lachelier, Lagneau e Duret inspirados em Alain (PP, pp. 17-18). É no mínimo curiosa a leitura de Peillon sobre esta questão. Ele defende que não houve realmente uma ruptura com a escola francesa da percepção. Não discutirei esta problemática, mas vale registrar esta passagem: "contrariamente à idéia recebida, o encontro da fenomenologia husserliana não tem lugar a partir de uma ruptura com a filosofia da percepção de Lagneau, Lachelier ou Alain. Na medida onde estes últimos tinham já posto em operação a crítica do dualismo da matéria e da forma, das sensações incoerentes e do julgamento intelectual, elas não devem ser assimiladas, sem outra forma de processo, à teoria neo-kantiana. Ao contrário, é somente a partir da questão da percepção como questão da verdade tal como a tradição elaborou que os resultados da Gestalttheorie são encontrados e a fenomenologia husserliana interpretada" (PEILLON, 2004, p. 32).

3 "Trata-se em suma de resgatar o erro comum da análise psicológica e da reflexão filosófica sobre a percepção para melhor encontrá-la como 'experiência direta', abaixo dos saberes científicos e filosóficos. Veremos então se abrir, nesta mesma experiência perceptiva, um 'campo fenomenal' que somente uma psicologia não analítica como a 'psicologia da forma' [Gestalttheorie] ou um método de descrição intencional (e, num sentido, não reflexivo) como aquele da 'fenomenologia' serão do mesmo modo considerados (...)” (WORMS in NCOG, p. 197). Para uma outra referência desta aproximação entre a fenomenologia e a Gestalttheorie ver Spiegelberg (1972, pp. 67-89).
} 
vida, buscando encontrar o real, o concreto, o mundo, as coisas, os outros, na espessura de nossa existência. É notável, também, por inspirar e ser um ponto de referência a um suposto “novo pensamento francês”: um pensamento com promessas mais engajadas à vida ${ }^{4}$. Aliás, este lema não só soa próximo de Merleau-Ponty como parece lhe ser um fio condutor. Waelhens chega a dizer, comentando esta “necessidade” em Merleau-Ponty, que “(...) é a vocação ao concreto que o tornou filósofo” (1961, p. 397).

Entretanto, há uma particulariedade em como Merleau-Ponty segue essa vocação ao concreto. Trata-se de compreender como se dá nossa relação direta com o mundo (PhP, p. 66). Fato talvez não tão inovador se lembrarmos que, desde 1935, Scheler já lhe inspirava este problema ao dizer de um "comércio direto com o mundo e com as coisas” (CR, p. 23; PhP, p. 262). Mas a herança husserliana parece dar um novo fôlego a esta empreitada. Refiro-me da herança da distinção, na fenomenologia husserliana (HUSSERL, 1950, § 16; 150), dos “modos de intencionalidade” da consciência com o mundo: “(...) há para a consciência muitas maneiras de visar seu objeto e muitos modos de intencioná-lo” (SC, p. 187) ${ }^{5}$. Interessa-me apontar aqui, brevemente, o porquê de Merleau-Ponty privilegiar um modo específico de intencionalidade.

É sabido como Husserl destacava que é somente a consciência perceptiva que tem um contato direto com o mundo. Isto se deve ao fato de que somente na percepção o objeto está

\footnotetext{
${ }^{4}$ É exatamente isto que Merleau-Ponty lê na filosofia contemporânea a si: "quando Bergson fazia da percepção o modo fundamental de nossa relação com o ser; quando Blandel se propunha a desenvolver as implicações de um pensamento que, de fato, se precede sempre, está sempre para além dele mesmo; quando Alain descrevia a liberdade apoiada sobre o curso do mundo como um nadador sobre a água que o retém e que é sua força; quando Croce recolocava a filosofia no contato com a história; quando Husserl tomava como protótipo a evidência da presença carnal da coisa, tudo remetia em causa ao narcisismo da consciência em si, tudo buscava uma passagem entre o possível e o necessário rumo ao real, tudo designava como uma dimensão que busca novamente nossa existência de fato e aquela do mundo" (PnP, pp. 195-196).

5 "Se todos os atos têm relação a um objeto, essa relação é diferente de um tipo de ato a outro e identifica-se à natureza da intenção. É o caráter da intenção que é distinto na percepção, na representação por imagens ou na representação por signos” (MOURA, 1989, p. 79).
} 
em proximidade, presente, “em carne e osso”. Qualquer outro modo nos levaria a um objeto não-presente, como é o caso da imaginação ${ }^{6}$.

Entretanto, diferentemente dos trabalhos husserlianos, para Merleau-Ponty, é um fato que, na percepção, tem um contato com a existência, com a facticidade (PhP, p. 50): a percepção nos dá o acesso mais concreto possível ao mundo, sem omitir seu sentido. Entretano, sabemos que Husserl havia assumido uma “auto-limitação” em suas primeiras análises: a análise transcendental seria uma análise eidética, isto é, a fenomenologia não diria de fatos, mas apenas de essências, e a redução eidética seria exatamente esta passagem à essência (HUSSERL, 1969, § 34). Isto significava simplesmente que a fenomenologia não poderia dar conta da experiência, mas apenas da natureza da experiência possível ${ }^{7}$.

Se o objetivo de Merleau-Ponty é buscar uma experiência direta com o mundo, ele não poderia seguir este projeto husserliano e protestava, apesar de censurar Jean Wahl de destacar a distinção de essência e existência em Husserl (PhP, p. x):

é contraditório afirmar ao mesmo tempo que o mundo é constituído por mim e que, desta operação constitutiva, eu só posso apreender o esboço e a estrutura essencial; é preciso que eu veja aparecer o mundo existente, e não somente o mundo em idéia no término do trabalho constitutivo, ou eu só teria uma constituição abstrata e não uma consciência concreta do mundo. Assim, em qualquer sentido que se toma, o 'pensamento de ver’ só é certo se a visão efetiva é assim (PhP, pp. 430-431).

Para Merleau-Ponty, é contraditório propor uma explicitação da constituição da experiência se “auto-limitando” a uma análise eidétia. Deste modo, não estranhamos que Merleau-Ponty re-definisse a fenomenologia:

a fenomenologia é o estudo das essências (...) mas a fenomenologia é também uma filosofia que repõe as essências na existência, e não se pode compreender o homem e o mundo de outra maneira senão a partir de sua 'facticidade'. É uma filosofia transcendental que coloca em suspenso, para compreendê-

\footnotetext{
${ }^{6}$ Como veremos, “(...) é em termos temporais que se deve compreender o privilégio da percepção em face dos outros atos da consciência, bem como a raiz da diferença que a separa da conssciência de imagem ou signo” (MOURA, 2001, p. 377-378).

${ }^{7}$ A fenomenologia enquanto doutrina da essência deixava em aberto a natureza factícia (o tema da filosofia contemporânea para Merleau-Ponty (PhP, p. 75)), não podendo explicitar aquilo que estivesse fora da essência. Por isso Husserl também nos lembrava que “o próprio fato, com sua irracionalidade, é um conceito estrutural no sistema a priori concreto” (HUSSERL, 1969, § 39). E também por isso o mundo sempre conservaria uma estranheza que ultrapassaria a essência. Afinal, a fenomenologia jamais poderia e nem pretendia esgotar as questões filosóficas, porque um horizonte inteiro de "irracionalidade" ficaria sempre aberto à nossa frente.
} 
las, as afirmações da atitude natural, mas é também uma filosofia para a qual o mundo já está sempre 'ali', antes da reflexão, como uma presença inalienável, e cujo esforço todo consiste em reencontrar este contato ingênuo com o mundo, para lhe dar enfim um estatuto filosófico (PhP, p. i, grifo meu).

Merleau-Ponty estaria assim opondo à “análise das essências”, uma “análise existencial” (PhP, p. 158) com base nas relações vividas (PhP, p. 241), e isto significava retomar o que afirmara na conclusão de La Structure du Comportement: a percepção é um ato que nos faz conhecer existências (SC, pp. 240-241; PhP, p. 50) ${ }^{8}$. Por isso Merleau-Ponty diz de uma “função existencial” na percepção (PhP, p. 350). E é também por esta causa que a percepção não seria um mero problema da filosofia, como diz Geraets (1971, p. 129), mas $o$ problema da filosofia mesma.

Merleau-Ponty sugere então pensarmos a partir da experiência vivida, pois toda experiência, toda percepção, pressupõe um mundo vivido. A herança ainda é husserliana, embora continue aqui a realizar uma leitura original do trabalho de Husserl, ao "reativar a problemática do sentido e das significações na exploração da experiência vivida”, como nos diz Hyppolite (1963, p. 4). Na verdade, Husserl (2004, §9) indicava um certo abismo entre o mundo vivido e o ideal científico que marcaria, desde Galileu, o modo de pensar “objetivo”: um mundo com “(...) uma totalidade infinita de objetividades ideais determináveis de modo metódico e absolutamente unívoco para todo o mundo” (HUSSERL, 2004, § 9f). Deste modo, o mundo objetivo passaria por cima de nossa relação mais direta com o mundo, apesar de sempre a pressupormos (2004, § 38). Geraets nos assegura (1971, p. 175):

este mundo da vida é, ele mesmo, sempre ‘operante’ como ‘fundo’ de toda atividade prática e teórica. O problema deste mundo não é somente aquele do saber como ele 'opera’ e deve 'operar’ para os homens da ciência — trata-se de um problema verdadeiramente universal que engloba todos os outros (...).

\footnotetext{
${ }^{8}$ Por isso o trabalho “infinito” de Cézanne, segundo Merleau-Ponty, de expressar o que existe (DtCz , p. 21), pois o real se dá numa exploração inesgotável (PhP, p. 374). Também de Proust de "traduzir uma experiência” re-fundando a linguagem ou, simplesmente, expressando de modo integral o vivido (RC, pp. 40-42). Não por acaso, a filosofia merleau-pontyana muitas vezes é dita como uma filosofia da existência, pois "as essências de Husserl devem trazer consigo todas as relações vivas da experiência, assim como a rede traz do fundo do mar os peixes e as algas palpitantes" (PhP, p. x), ou, como anota anos depois: "viver, para um homem, não é somente impor perpetuamente as significações, mas continuar um turbilhão de experiências que é formado (...)” (RC, p. 67).
} 
Este parece ser o "grande projeto" de Merleau-Ponty na Phénoménologie de la Perception, chegando a levá-lo a se igualar à retomada deste mundo vivido com o "primeiro ato filosófico” (PhP, p. 69) ${ }^{9}$. Entendamos: este “retorno” é, dentre várias pretensões, também um retorno ao como nos relacionamos com o mundo, ao como experiênciamos en train de... (no gerúndio: vivendo ou percebendo este mundo) ${ }^{10}$. Era exatanente isto que o filósofo já admirava, em 1936, ao ler a obra de Marcel: os atos do homem nas situações vividas (EtAv, p. 39), e era também por isto que seria preciso definir o homem por sua experiência ou como existe de fato (PhP, p. 198): “(...) em toda pesquisa feita sobre os homens, a referência ao vivido é indispensável” (Sorb, p. 298). Isto ficará mais claro nos próximos capítulos.

Por agora, é importante entendermos o porquê de se tratar de "um primeiro ato filosófico”. Para o filósofo, é preciso combater uma “obsessão” quase que espontânea em nosso contato com o mundo (PhP, p. 85): de determiná-lo. Não é por menos que MerleauPonty começa seu trabalho, na Phénoménologie de la Perception, mostrando como esta obsessão é um processo tardio da experiência. Trata-se de prejuízos clássicos analisados pelo filósofo, seja no nível da sensação (como impressão, qualidade ou uma conseqüência imediata de uma excitação) (PhP, pp. 9-19), seja no nível da associação e da projeção de lembranças (PhP, pp. 20-33), ou mesmo no nível da atenção e do julgamento (PhP, pp. 34-63). Na verdade, não nos interessa aqui retomar os pormenores destas críticas, mas compreender em que elas se baseiam. Esta passagem que se segue é bem clara: há um prejuízo mais geral que

\footnotetext{
${ }^{9}$ Mesmo anos depois da Phénoménologie de la Perception este tema está presente, como o filósofo resume nesta passagem: "o retorno ao Lebenswelt como característica da fenomenologia - O Lebenswelt é o problema ‘universal' — Contém 'tudo'. É preciso encontrar a dimensão anterior à objetivação” (NC, p. 77).

${ }^{10}$ Isto é possível a Merleau-Ponty porque o termo vivre (que se traduz do leben husserliano) tem também um sentido transitivo na língua francesa. Vale a transcrição desta passagem precisa de Barbaras (2005b, p. 210): "Husserl não escolheu esta palavra arbitrariamente [Leben]: ele tirou vantagem do duplo sentido que Leben tem em alemão, que é também ambíguo em francês. O significado de 'viver' é originalmente intransitivo: viver significa estar vivo; vida é o que caracteriza os seres vivos. Em alemão, o verbo leben torna-se o verbo erleben, que tem um sentido transitivo (como vivre em francês): significa ter experiência, sentir, perceber, e isto se refere a um objeto tanto imanente (pode-se viver, ou erleben, uma emoção, como ter um caso de amor passional) ou a um objeto transcendente (vivre, erleben uma situação)”.
} 
engloba o atomismo ou o associacionismo: "o prejuízo do ser determinado ou do mundo (..)” (PhP, p. 62).

Por exemplo, a crítica merleau-pontyana no nível da sensação, enquanto impressão, se baseava em determiná-la como um instante pontual (PhP, p. 9). Enquanto qualidade, como "puro sentir” (PhP, p. 11). Enquanto uma conseqüência imediata de uma excitação, uma “conexão pontual entre estímulo e reação” (PhP, p. 14). Em todos os casos, a grosso modo, trata de pontuar, determinar a sensação. No nível da associação e da projeção de lembranças, de um modo geral, acontece o mesmo. No primeiro caso, na associação de "elementos" (PhP, p. 21). No segundo, na projeção de "lembranças pontuais” (PhP, p. 29). Merleau-Ponty insiste neste tema, mesmo que mais discretamente, também na atenção e no julgamento. A atenção era entendida como um "mundo de impressão em si” ou como um "universo de pensamento determinado” (PhP, pp. 36-37). O julgamento, por outro lado, passa a ser um "princípio explicativo”, que se baseia numa percepção pontual (PhP, pp. 42-43). A crítica geral pode se esboçar deste modo em cima do “ser determinado”.

Mas aí podemos questionar: não podemos então determinar o mundo? Certamente que sim. O que o filósofo quer destacar é que a determinação se dá diante de um indeterminado. É um processo "tardio", não a experiência efetiva diante do mundo. Trata-se de resgatar esta experiência, de mostrar que o mundo determinado, o pensamento “objetivo”, como denomina Merleau-Ponty, se dá a partir de algo indeterminado. Não é o caso de simplesmente dizer que o pensamento objetivo está “errado”, mas que ele se nutre de algo “indeterminado”. O pensamento objetivo partiria do “resultado” da percepção.

Como então buscarmos este indeterminado? A estratégia de Merleau-Ponty neste ponto é interessante: seria preciso encontrar um campo de experiência que correspondesse ao nosso contato direto com o mundo (antes mesmo de nós o determinarmos). Seria necessário acompanharmos novamente Husserl (1950, § 67): é preciso voltarmos “à coisa mesma”, à 
coisa dada em pessoa (gegeben selbstgegeben), no modo originariamente dado (originärgegeben) ou corporalmente dado (leibhaft $)^{11}$. Ou seja:

retornar às coisas mesmas é retornar a este mundo anterior ao conhecimento do qual o conhecimento fala sempre, e em relação ao qual toda determinação científica é abstrata, significativa e dependente, como a geografia em relação à paisagem, pois primeiramente nós aprendemos o que é uma floresta, um prado ou um riacho (PhP, p. iii) .

Assim, fica-nos claro o porquê do título da introdução da Phénoménologie de la Perception: Les Préjugés Classiques et le Retour aux Phénomènes.

Ainda uma questão: mas o que significa retornar aos fenômenos? Para o filósofo, isto tem um sentido claro: significa retomar o mundo em sua brutalidade, num campo préobjetivo, fora do “prejuízo do mundo objetivo”. É preciso encontrar um campo fenomenal que nos dê acesso à experiência direta com o mundo (PhP, p. 66). Mas é preciso ressaltar: ver as “coisas mesmas” não significa ver sua totalidade, como destacarei, mas vê-las em sua fisionomia, em seus perfis, pois “o mundo é aquilo que nós percebemos” (PhP, p. xi) e “(...) é impossível separar as coisas e seus modos de aparição” (C, p. 54). Waelhens (1968, p. 216) precisa esta idéia: “o que nós vemos realmente não é uma coisa, mas uma Abschattung da coisa, Abschattung engajada no horizonte do mundo (...)”.

\section{2) $\mathrm{O}$ campo perceptivo}

É certo que a percepção não é um tema recente. Na verdade, não se trata de reinvindicar uma nova problemática, mas de tomá-la de um novo modo. Por isso, desde a

\footnotetext{
${ }^{11}$ Eugen Fink faz uma analogia muito interessante neste ponto. Ele compara a situação permanente do homem com os acorrentados da alegoria da caverna (FINK, 1974, pp. 178-180): estes homens vêem um mundo de prejuízos, determinado, limitado, e jamais as "coisas mesmas". Ao ser libertado, o homem que sai desta caverna veria como são as coisas. Ao retornar à caverna, ele veria como o ser determinado lhe ofuscava a visão e como é inacessível aos homens que permaneceram na caverna de entenderem o que aquele homem viu fora da caverna: "a violência simbolizada nesta alegoria, a tensão e o esforço de realização do filosofar determinam a filosofia fenomenológica de Husserl” (FINK, 1974, p. 180).
} 
primeira página da introdução da Phénoménologie de la Perception, Merleau-Ponty se preocupa em contrapor os “prejuízos” da tradição com as novas pesquisas da psicologia e da fisiologia. Como vimos, de um modo geral, podemos dizer que a tese é que o mundo percebido não comporta a idéia de um ser determinado (PhP, p. 62). Por exemplo: não há como distinguirmos ou determinarmos um elemento na paisagem sem dizer que cada parte anuncia mais que ele contém e, neste sentido, ela é então já carregada de um sentido (PhP, p. 9). Toda percepção se daria assim na “relação” das coisas que percebemos.

Já na segunda página da Phénoménologie de la Perception, a tese de Merleau-Ponty ganha corpo, se baseando na Gestaltheorie, formulando, diga-se de passagem, aquilo que Cézanne já pintava, segundo Merleau-Ponty, ao ser fiel ao mundo percebido (DtCz, p. 19):

quando a Gestaltheorie nos diz que uma figura sob um fundo é o dado sensível mais simples que nós podemos obter, isto não é um caráter contingente da percepção de fato, que nos deixariam livres, numa análise ideal, de introduzir a noção de impressão. É a definição mesma do fenômeno perceptivo, daquilo sem a qual um fenômeno não poderia ser dito como percepção. O 'algo' perceptivo está sempre no meio de outra coisa, ele sempre faz parte de um 'campo' (PhP, p. 10)

Ou seja, “isolar” um elemento ou “determinar” um elemento é destacá-lo de uma relação que é essencial em toda percepção: é preciso dizer de uma “estrutura da percepção” que nos mostraria o que é perceber (PhP, p. 10). Como compreendermos isso?

Sabemos que, no início do século XX, Ehrenfels chamava a atenção da comunidade científica ao dizer que o todo é uma Gestalt qualitativa: algo que está presente no todo, mas não em suas partes. Tomemos um exemplo: há “algo” numa melodia que a distingue de todas as outras, pois ela não é um simples composto de notas, ritmo e harmonia da qual se poderia somar estes elementos, sintetizando sua unidade. Ela é um “complexo unitário”. E por que um complexo? Antes de mais nada, porque há uma certa relação dos elementos intrínseca à sua relação total, que podemos verificar ao cantarmos ou assoviarmos uma melodia: certamente assoviamos num tom diferente da melodia “original”, mas reconheçemos facilmente qual melodia é ao escutarmos. Parece que há algo intrínseco à relação das notas que nos faz 
reconhecê-la. Ora, se todas as notas foram alteradas (estão num outro tom) e ainda continua sendo para nós a mesma melodia, é porque ela é um todo, guardando sua própria identidade (e bastaria cantarmos uma nota diferente para estranharmos ou dizermos que se trata de uma outra melodia. $)^{12}$.

Um outro exemplo: Wertheimer formula no início da segunda década um problema interessante (dentre muitos outros): se com a cinematografia percebemos movimento (se há realmente uma percepção de um movimento na tela) então não é uma ilusão que estejamos experimentando diretamente este movimento como um todo, apesar de haver intervalos entre as imagens (GUILLAUME, 1937, pp. 89-101). Isto parece apontar que a percepção do movimento não depende da seqüência dos estímulos nos pontos da retina, como argumentava as doutrinas introspectivas. Ou seja, a "natureza” da experiência do movimento deve ter um "significado" que não pode ser encontrado em suas partes. A percepção depende da “organização total” do campo que nos estimula e dos processos dinâmicos do cérebro (e não da soma das partes dos estímulos deste campo). Dizendo de outro modo, não seria partindo dos elementos do campo perceptivo que o tomaríamos como um todo, mas percebemos um todo, segundo uma estrutura ordenada e determinada, da qual podemos individualizar suas partes. Nada mais claro:

a ‘fórmula' fundamental da teoria da Gestalt pode ser expressa assim: há totalidades e o comportamento de cada um de seus elementos não pode ser determinado por sua individualidade, mas os processos parciais o são pela natureza intrínseca do todo. É o desejo da teoria da Gestalt determinar a natureza destas totalidades (WERTHEIMER in ELLIS, 1955, p. 2).

Na verdade, Husserl já havia apontado no terceiro livro da Logische Untersuchungen duas modalidades de "todo": um autêntico e outro não-autêntico, sendo que o que lhes distinguiriam seriam as relações de suas partes. No último caso, haveria uma relação onde as

\footnotetext{
12 Esta “constatação” parece ser um dos pontos centrais para o início do pensamento gestaltista: reconhecer que o todo é uma realidade, como a cor e os elementos o são, por exemplo, para nós. Além do que, revela-nos um "fenômeno" de transposição (ou seja, certas propriedades permanecem constantes quando são alterados todos os elementos de alguma maneira), do qual a qualidade do todo pode ser transposta (no caso, de um tom a outro) (GUILLAUME, 1937, pp. 16-21).
} 
partes dependeriam de um elemento exterior ao todo. No outro, as partes estariam numa relação de dependência entre si, e não a algo exterior ao todo: as partes estariam numa “conexão necessária”, numa relação de fundação (Fundierungsverhältnis) (HUSSERL, 1962, p. 46).

Qual a importância disto a Merleau-Ponty? Ora, esta relação em que todas as partes estão numa relação de dependência entre si nos leva a pensar o “campo perceptivo” a partir desta mesma relação. É precisamente esta organização do campo perceptivo que a Gestalttheorie pretende estabelecer (KÖHLER, 1947, pp. 104-105). Os gestaltistas visam encontrar "leis”, ou uma certa “dinâmica de articulação”, que possam descrever este processo organizacional. Isto significa simplesmente que a organização é um processo (em extensão, ou seja, não isolado, em extensão ao todo) que depende também da organização do meio.

Por exemplo: "se as condições são tais que se pode produzir segregações tanto das partes maiores como das menores unidades, a menor se tornará a figura; a maior, o fundo” (KOFFKA, 1955, p. 191). Ou ainda: o “princípio de fechamento” (quando completamos imediatamente pontos que sugerem uma cruz). Isto indica uma "tendência” espontânea que temos diante de um campo perceptivo, revelando outro princípio dinâmico que Wertheimer já destacava como sendo a "lei da boa forma” (ou law of Prägnanz): “o princípio afirma que a organização do campo tende a ser o mais simples e limpo como é compatível com as condições em cada caso” (KÖHLER, 1938, p. 251). Organização em que o significado se destaca segundo uma outra lei específica da Gestalttheorie, relativa à organização deste campo perceptivo, que segue o dado sensível mais simples que podemos obter — a relação figura/fundo. Ele diz: “a figura depende das características do fundo que aparece. O fundo serve como estrutura na qual a figura é suspensa de tal modo que determina a figura” (KOFFKA, 1955, p. 184) — como um som se destaca de um fundo "mudo". 
O que há de realmente "novo” nesta formulação é a afirmação de que a percepção de formas não é uma construção ou uma combinação de processos mentais ou a condição de possibilidade da aparição de uma figura, mas um "processo de organização” que se dá no próprio campo perceptivo (PhP, p. 82; UAC, p. 128). Não é preciso determinar os elementos de uma figura para que ela seja percebida, pois percebemos uma forma, espontaneamente, onde todos os elementos estão relacionados entre si.

Sem nos prolongarmos mais neste problema, interessa-nos destacar que isto permite a Merleau-Ponty dizer que, ao perceber, por exemplo, um rosto, uma fisionomia, não se percebe, necessariamente, a cor dos olhos desta pessoa, os traços da bochecha ou a cor do cabelo. Para Merleau-Ponty, isto significa que percebemos uma certa fisionomia nas coisas ou uma certa expressão que compreendemos. Guillaume (1937, p. 191) é bastante preciso nesta passagem:

o que percebemos primeiramente, num rosto humano, é a expressão global. Nós o percebemos como um todo, como uma unidade natural, embora se trate aqui de um todo de complexidade diferente dessas formas geométricas privilegiadas, que tomamos como exemplos no estudo da percepção. Ora, a unidade desse todo é a de uma expressão. É a expressão que desaparece quando isolamos umas partes das outras, por exemplo, escondendo o conjunto de um retrato, para considerar separadamente as partes. É a expressão que se modifica, muitas vezes de modo profundo, por uma alteração local e minúscula de um traço, que repercute na fisionomia do conjunto. É a expressão que permanece na memória e permite o reconhecimento; é ainda ela quem sugere semelhanças, algumas vezes desconcertantes, muitas vezes clarividentes e penetrantes, entre pessoas. A expressão é uma forma de um tipo muito primitivo.

Não se trata assim da soma de caracteres, mas do conjunto, da "organização" desta forma: "uma coisa é uma coisa porque o que quer ela nos diga ela nos diz por sua organização de seus aspectos sensíveis” ( $\mathrm{PhP}$, p. 373). Na verdade, como indica Guillaume, esta organização se oferece a nós como uma expressão, ou, como Merleau-Ponty nos diz, trata-se da linguagem das coisas (PhP, p. 372). O filósofo parece seguir aqui também os passos de Scheler (1928, pp. 348-349): “(...) a ‘expressão’ é a primeira coisa que o homem percebe naquilo que existe exterior a ele”.

Mas é importante também destacarmos que a fisionomia humana é uma forma privilegiada das significações humanas, principalmente para a criança, como observa Koffka 
(1928, p. 301 et seq.). Merleau-Ponty acompanha: “um rosto é um centro de expressão humana” (SC, p. 181). Aliás, esta expressão é tão privilegiada que Merleau-Ponty chega a afirmar que “a significação humana é dada antes dos pretensos signos sensíveis” (SC, p. $181)^{13}$. Ora, a criança é atenta a esta significação: ela retribui um sorriso. Mas perguntemos novamente: qual o interesse disto ao filósofo?

Isto é muito profundo para Merleau-Ponty, a meu ver, pois, pensando estrategicamente na percepção começante, juntamente com a Gestalttheorie, poderíamos perceber que os próprios gestos maternos parecem apontar um “sentido latente” no sensível. É por isso que era preciso a Merleau-Ponty partir da percepção infantil, como nos diz Geraets (1971, p. 70). Se a criança compreende, num certo momento, a expressão fisionômica, como o sorriso, é porque ela apreende, de algum modo, o sentido do gesto humano (SC, p. 169) (o que também já supõe uma relação com o outro (Sorb, p. 16)). É preciso, assim, admitir uma certa ordem que está latente no “campo perceptivo”. Aliás (e este é um passo importante), é preciso admitir que “(...) toda Gestalt tem ordem e significado, em baixo ou alto grau (...)”, como diz Koffka (1955, p. 22).

Se a Gestalttheorie estiver correta, poderíamos descrever no momento da própria experiência a emergência dos significados indecomponíveis (SC, p. 185). Quer dizer, se a experiência infantil não começa pelo caos, mas por um mundo cuja estrutura é somente lacunar (SC, p. 192), então as coisas já teriam um sentido para a criança antes que ela tenha a "capacidade” ou maturação estrutural suficiente de julgá-las. A criança seria assim capaz de compreender o sentido de uma certa "fisionomia”, mesmo que tenhamos que concordar que esta compreensão seja mais “pobre” que a adulta. Afinal, se a noção de forma nos proíbe

\footnotetext{
${ }^{13}$ Outros objetos privilegiados, talvez menos que o rosto humano, mas ainda assim privilegiados, são os de uso e os objetos de cultura (SC, p. 175). A criança manuseia-os sem saber ainda sua utilidade. Ela os explora, mas são antes uma "fisionomia” do que uma “coisa”, pois ela visa sua significação (SC, pp. 181-182). E o problema é novamente aqui um problema gestaltista, pois “é aqui que a noção de 'forma' nos permitirá seguir a análise. A forma é uma configuração visual, sonora, ou mesmo anterior à distinção de sentido, em que o valor sensorial da cada elemento é determinado por sua função no conjunto e varia com ele” (SC, p. 182).
} 
de pensar em processos isolados que se associem, introduzindo a noção de "processos globais”, então é porque existe uma certa ordem que é imanente à própria fisionomia: a criança reconhece sua mãe, mesmo sem saber a cor dos seus olhos; retribui um sorriso, sem ser preciso julgar este ato ${ }^{14}$.

Mas isto não exclui do mundo uma certa "indeterminação", pois o mundo não pode ser totalmente apreendido. Há um sentido latente que posso compreender, mas há também uma certa “indeterminação positiva” no mundo. Lembremos novamente desta passagem: “cada parte anuncia mais que ele contém e esta percepção elementar é então já carregada de um sentido” (PhP, p. 9). Isto significa afirmar que o sentido do mundo só pode ser apreendido em relação ao próprio “campo perceptivo” que vejo: ele mesmo se presta a uma exploração infinita e seus sentidos remetem à própria organização deste campo que percebo. Isto dá uma margem de "indeterminação", uma vez que seu sentido me reenvia a ele mesmo, sem que eu possa determiná-lo definitivamente. Para Merleau-Ponty, isto atesta uma "riqueza” do mundo percebido, uma “inesgotabilidade”, pois, “longe de introduzir na percepção um coeficiente de subjetividade, isto nos dá, ao contrário, a garantia de comunicar com um mundo mais rico”

\footnotetext{
${ }^{14}$ Esta proposta é estratégica, a meu ver, porque não bastaria aqui dizer que a consciência infantil é menos organizada que a consciência adulta, pois “a percepção infantil será, contudo, organizada, mas a seu modo. Este é um princípio que a Gestalttheorie propõe à psicogênese, que o desenvolvimento não se faz por simples junção ou acréscimo, mas por reorganização (Koffka)” (PP, p. 32). Trata-se assim de dizer que a percepção infantil é estruturada desde o começo, sem com isto afirmarmos um "inatismo" ou igualando sua estrutura perceptiva ao do adulto. "Trata-se de uma estrutura sumária com lacunas, regiões indeterminadas, e não da estruturação precisa que é aquela do adulto. Na medida em que a criança se desenvolve, têm-se transformações, reorganizações. Mas desde o início existem conjuntos que merecem o nome de coisas e constituem um mundo” (Sorb, pp. 192-193; cf. MH, p. 104). Merleau-Ponty age como se prevenisse os leitores das análises piagetianas, que buscam mais o que falta à criança (sua não-completude) do que saber o que ela realmente é (Sorb, p. 200). Ou seja, Piaget parece buscar explicar o adulto recorrendo à criança, e a criança recorrendo ao adulto (PIAGET; INHLEDER, 1986, p. 9), afirmando assim uma espécie de "continuísmo”, ou uma "evolução", como se daqui a ali se desenvolvesse progressivamente. Por este caminho, Piaget parece apontar uma perspectiva do desenvolvimento infantil em função do adulto. Isto significa que ele considera a criança como "germe” em direção à maturidade, ou como algo imperfeito que tende a se aperfeiçoar, como uma tendência a um "acabamento” adulto. Seja assim, a criança passaria sucessivamente por processos que tenderiam a uma coerência cada vez mais complexa aos olhos deste cientista, como se, em cada fase, a percepção do mundo estivesse em vias de se completar cada vez mais nas relações próprias dos esquemas de ação da criança. A censura merleau-pontyana não é um mero acaso, pois, por esta via, a criança agiria como se o "mundo" impusesse a ela uma certa conduta à qual deveria ser coerente, apontando mais um sentido "negativo" da percepção e, menos, o que lhe é própria. Haveria assim sempre uma insuficiência perceptiva, já que seria preciso pensar a estrutura cognitiva infantil como algo imperfeito (PIAGET, 1980, p. 73). Se isto fosse verdade, a descrição da percepção seria a descrição de uma "história” evolutiva de adequação do percebido, e jamais poderíamos acompanhar assim a noção de ordem no campo perceptivo que a Gestalttheorie nos apresenta.
} 
(SC, p. 201). Era exatamente isto, esta indeterminação positiva, que a "nova” psicologia proferia.

Este tema, em Merleau-Ponty, é bastante importante, porque restitui a "opacidade do mundo” ou, mesmo, restitui ao mundo percebido uma certa “ambigüidade” (PhP, p. 18). Por isso Merleau-Ponty se contrapunha à tradição "ultra-racionalista” francesa: é uma falsa aparência dizer que o mundo percebido é o mundo melhor conhecido por nós (C, p. 11). Na verdade, ele nos é amplamente ignorado: há uma certa ambigüidade no mundo que não pode ser plenamente determinado ou uma “indeterminação positiva” no mundo. Esta passagem merece nossa atenção:

é ora a aderência do percebido a seu contexto e como que sua viscosidade, ora a presença nele de um indeterminado positivo que impede os conjuntos espaciais, temporais e numéricos de se articularem em termos manejáveis, distintos e identificáveis (PhP, p. 19, grifo meu).

E aqui entra um paradoxo que deve ser pautado: é certo que a unidade das coisas, antes de ser posta pelo conhecimento, já nos é dada de algum modo (é vivida como já realizada (PhP, p. xii)), mas, se é próprio do percebido ser ambíguo ou do mundo se prestar a uma exploração infinita, como é possível explicar este fato já acontecido ou o fato de haver uma unidade para mim (PhP, p. 381)?

\section{3) Questões em torno da perspetiva espacial e temporal do corpo}

Esta questão é fundamental, a meu ver, porque se refere diretamente a um sujeito de percepção que está situado frente ao mundo e que deve, de algum modo, sintetizá-lo, pois “as coisas e os instantes só podem articular-se uns aos outros para formar um mundo através deste ser ambíguo que chamamos de subjetividade (..)” (PhP, p. 384). O problema é que este sujeito de percepção só pode perceber o mundo sob uma “inadequação”. 
Na verdade, o tema é husserliano novamente: quando dizemos que os objetos que percebemos, percebemo-os de forma inadequada, numa aparência fechada, finita (in abgeschlossener Erscheinnung (HUSSERL, 1950, § 44)), estamos dizendo, assim como em Ideen zu einer reinen Phänomenologie und phänomenologische Philosophie I, que vemos “perfis das coisas” ou que temos “percepção de perfis” (HUSSERL, 1950, § 42). Isto era algo fundamental a Husserl, já que ali todas as coisas (os objetos percebidos) eram entendidas como um X idêntico, vazio, com múltiplos modos de doação (HUSSERL, 1950, § 131). Ou seja, tratava-se de pensar que toda percepção das coisas implicava num “horizonte” inteiro de modos de aparição, em seus múltiplos modos de doação, num horizonte inesgotável.

Como se pode perceber, este “horizonte inesgotável” também implica num infinito de aparições de cada objeto. E aqui está o problema que apontava acima: este horizonte não é uma imperfeição relativa da existência do meu corpo e de seu ponto de vista próprio (SC, p. 201), é a própria “essência da coisa espacial” que, por princípio, é dada por perfis a um sujeito perceptivo situado num campo específico. Lembremos que Husserl em Ideen I dizia que isto significava que cada orientação corresponde uma certa maneira de uma coisa sempre ser vista de modo “inadequado”, em face, em perspectiva: “toda percepção e todo modo de percepção são suscetíveis de serem alargados; o processo é então sem fim” (HUSSERL, 1950, § 149). Moura resume este problema de um modo claro (2001, pp. 197-198):

a fenomenologia sempre descrevera a nossa percepção de um objeto espacial como perpetuamente inadequada. E essa inadequação era uma necessidade de essência a partir do momento em que o fenomenólogo situava nossa percepção no entrecruzamento entre o ‘perfil dado' e um 'horizonte’ de perfis apenas visados, que Husserl descrevera serem infinitos. Assim decodificada, a 'percepção da coisa espacial' estava condenada a um desdobramento que deveria prosseguir indefinidamente, e a 'coisa percebida', correlativamente, só podia ser vista como um objeto inesgotável do qual, por princípio, só posso ter perspectivas parciais e unilaterais. Husserl era levado à tese segundo a qual a ‘doação adequada’ do objeto percebido era uma ‘idéia situada no infinito’.

Esta inadequação é importante a Merleau-Ponty porque estabelece uma relação entre a estrutura da percepção com a organização corporal: há uma perspectiva espacial em todo ato perceptivo. Em outros termos: é preciso situar o sujeito de percepção diante de um mundo — 
este sujeito de percepção é o corpo que está sempre situado no mundo. Ora, toda percepção me

(...) reenvia à posição de um mundo e de um sistema da experiência em que meu corpo e os fenômenos estejam rigorosamente ligados. Mas o sistema da experiência não está desdobrado diante de mim como se eu fosse Deus, ele é vivido por mim de um certo ponto de vista, não sou seu espectador, sou parte dele, e é minha inerência a um ponto de vista que torna possível ao mesmo tempo a finitude de minha percepção e sua abertura ao mundo total enquanto horizonte de toda percepção (PhP, p. 350).

Entre outras coisas, não é por menos que Merleau-Ponty afirma que a "profundidade” é a mais existencial das dimensões (PhP, p. 296), pois se por um lado a profundidade era entendida por Berkeley, por exemplo, como algo invisível para nós que nem poderia ser dada à nossa visão, é porque Berkeley assimilava a profundidade à largura, numa noção geométrica. Para Merleau-Ponty, isto é o mesmo que dizer que o sujeito berkeleyano é um sujeito a-cósmico, sem situação, que não vê o mundo em perfil, porque está "em toda parte e parte nenhuma”. Para ver a profundidade é preciso estar situado, é preciso ser um corpo vendo o mundo daqui, em perfil. A profundidade é exatamente aquilo que torna possível a coexistência das faces do cubo que vejo daqui: eu vejo o cubo neste perfil, mas meu olhar já o habita, já vê seus lados quadrados, mesmo que o geômetra me corrija ao dizer que estou vendo este lado como um losango, por exemplo. É porque a profundidade não pertence propriamente ao cubo, mas à minha situação diante dele. É porque a profundidade pertence à minha perspectiva sobre as coisas (PhP, p. 306). E é por isso que ela é a mais "existencial” das dimensões para Merleau-Ponty: porque afirma a minha existência corporal ou a perspectiva espacial do corpo diante do mundo.

Mas dizer que sempre estou numa perspectiva espacial, vendo o mundo em perfis, não significa afirmar simplesmente que não posso realizar nenhuma síntese perceptiva, nos deixando sempre diante de um "mundo fragmentado”. Ao contrário, a perspectiva espacial do corpo nos remete a um “saber espacial” diferentemente da determinação do mundo. Não se trata, como neste último caso, de um suposto sujeito em “sobrevôo” ao mundo (PhP, pp. 81; 
235-236), sem situação, pois nos apontaria menos uma “posição espacial” e mais uma "atitude de pensamento” (AUBERT, 2005, p. 194) — um ponto de vista de ausência de ponto de vista. Hyppolite (1963, p. 9), por exemplo, adverte:

\begin{abstract}
Merleau-Ponty insiste aqui sobre um tema maior de seu pensamento, aquele perigo de uma inteligência que acredita se libertar de seu enraizamento, que substitui ao sentido ambíguo de sua vida, uma significação ideal e talvez ilusória, uma inteligência que pensando o mundo cessou de habitá-lo, de freqüentá-lo.
\end{abstract}

Esta passagem de Merleau-Ponty é bem clara neste sentido:

é-nos natural crer em presença de um mundo e de um tempo que nosso pensamento sobrevoa e que ela possa considerar à vontade cada parte sem modificar a natureza objetiva. A ciência, em seu começo, toma e sistematiza esta crença. Ela subentende sempre um observador absoluto em que se faz a soma dos pontos de vista e, correlativamente, um geometral de todas as perspectivas (MH, p. 113).

Diferentemente do “geometral de todas as perspectivas” (PhP, p. 50), poderíamos dizer ao mesmo tempo de um sujeito em situação e de uma síntese perceptiva que me permitiria perceber a unidade do objeto, embora isto não signifique “esgotar o objeto”. Sabemos que há sempre um horizonte possível de todo objeto. Na verdade, é o próprio tempo que impediria que as coisas fossem dadas de uma vez por todas. Certamente, seria humanamente impossível alcançar a sua ipseidade: isto nos levaria a pensar numa esgotabilidade do mundo (MOUTINHO in GONÇALVES et al., 2006, p. 93) ou mesmo naquilo que o filósofo se esforça por negar: uma subjetividade absoluta. Acompanhemos Waelhens (1968, p. 178) nesta passagem: “a síntese perceptiva (...) não possui o pleno segredo do objeto: ele se manifesta como uma unidade transcendente ao Abschattungen, às perspectivas que temos sobre ele”.

Fato certamente curioso, uma vez que não podemos alcançar a ipseidade de uma coisa, apesar de "todo o saber se instalar nos horizontes abertos pela percepção" (PhP, p. 240). É certo que a percepção, sendo o ato que constitui nosso comércio com o mundo de forma mais concreta, tem como função essencial fundar ou inaugurar o conhecimento (PhP, p. 24). Por outro lado, este ato não garante “a posse da verdade”, mas também não faz do nosso 
conhecimento um puro “relativismo". É o preço de sermos seres encarnados: só posso conhecer algo a partir da minha experiência perceptiva, entretanto “o próprio sentido da coisa se constrói sob nossos olhos, um sentido que nenhuma análise verbal pode esgotar e que se confunde com a exibição da coisa em sua evidência” (PhP, p. 373). Sendo assim, “a posse da verdade” do mundo é uma posse creditada, presumida, num mundo que percebo e que não sou capaz de agarrar por completo (como veremos mais à frente):

eu digo que percebo corretamente quando meu corpo tem sobre o espetáculo uma tomada precisa, mas isto não quer dizer que minha tomada seja total (...). Numa experiência de uma verdade perceptiva, eu presumo que a concordância experientada até aqui se manteria para uma observação mais detalhada; eu confio no mundo. Perceber é empenhar de um só golpe todo um futuro de experiências num presente que, a rigor, não o garante jamais, é crer num mundo. É esta abertura a um mundo que torna possível a verdade perceptiva (...) (PhP, p. 344).

Mas crer num mundo não significa seguir o modelo objetivo: se, ao primeiro olhar, as coisas parecem absolutamente determinadas, é porque não despertamos em nós nossa vida “intencional” que engrenda as coisas (PhP, pp. 383-384).

Para compreendermos este problema apontado acima, é mister retomarmos, novamente, algumas questões da fenomenologia husserliana. Lembremos primeiramente que a intencionalidade é o tema central da fenomenologia, segundo Husserl (1950, §84). Seja percebendo ou imaginando ou julgando, o pressuposto não muda: toda consciência é consciência de alguma coisa; ou: todo objeto é objeto para uma consciência ${ }^{15}$. Mas é certo que Husserl ampliava a noção de intencionalidade, ao dizer de uma "intencionalidade de ato", que dá sentido às várias faces de um objeto idêntico. O que isto significa? Significa que cada objeto da experiência, na verdade, reenvia a outros objetos no campo da experiência. Em Der Krises der europäischen Wissenschaften und die transzendentale Phänomenologie, por

\footnotetext{
${ }^{15}$ Para Husserl, a consciência deveria ser pensada segundo aquele "todo autêntico" de que dizíamos acima, não deixando nada exterior a ela e com todos seus os "elementos" numa relação entre si. Isto lhe possibilitava indicar uma inversão da relação todo/partes da orientação natural para uma orientação fenomenológica, instaurando uma correlação entre a consciência e seus objetos intencionais: a consciência e os objetos são partes de um mesmo "todo". Não poderíamos dizer que há uma intencionalidade por um lado e um objeto intencionado por outro: toda consciência é consciência de alguma coisa e todo objeto é objeto para uma consciência. Isto tem uma conseqüência importante, como nos lembra Madison (1990, p. 65): “(...) o mundo tem sentido somente em relação ao sujeito e é impossível conceber um mundo que não fosse um mundo para a consciência”.
} 
exemplo, Husserl dizia que cada coisa percebida reenvia à totalidade das coisas ao seu redor

(2004, § 47): uma coisa só é uma coisa num mundo de coisas percebidas. Moura resume este problema nestes termos (2001, p. 179):

a percepção remete a um objeto percebido; nesse objeto, o lado que me é dado remete a um lado que não é dado; e o objeto todo remete a um horizonte de outros objetos que estão implicados no objeto atual de minha consciência; enfim, todos eles remetem ao mundo que é o horizonte geral de minha experiência.

Na Cartesianische Meditationen, Husserl dizia o mesmo (1969, § 19): cada vivido singular só emerge sob um fundo de uma consciência do todo que este indivíduo singular sempre pressupõe. Se o que é dado não reenviasse ao não dado, não teríamos como ter consciência de nenhum objeto, nem do mundo da experiência. Fink comenta (1974, pp. 239240) :

Husserl, por sua parte, começa refletir sobre a árvore no quomodo de seus modos de aparecer. A árvore vista é vista por um lado, mas toda a árvore é implicada neste lado, toda a árvore, quer dizer, os outros lados não vistos ainda e que serão possíveis de serem vistos; dando voltas em torno da árvore eu veria sempre um lado, os outros estariam implicados nele; a árvore me apareceria num sistema que se poderia examinar com precisão, de dados parciais, de modos de aparecer que lhe são inseparáveis.

É isto que Merleau-Ponty tem em vista ao pensar a percepção:

assim, parece que nós fomos conduzidos a uma contradição, a crença na coisa e no mundo não pode significar a presunção de uma síntese acabada — e, entretanto, este inacabamento é tornado possível porque cada uma delas reenvia indefinidamente aos horizontes de outras perspectivas (PhP, p. 131).

Haveria como um sistema de reenvios onde cada objeto exprime outro, o que Merleau-Ponty denominará de "expressão": cada parte exprime o todo. Ou seja, no real, cada momento é "sinônimo” de outros, numa “equivalência absoluta” (PhP, p. 373). Esta passagem do filósofo é clássica:

uma coisa é uma coisa porque, o que quer que ela nos diga, ela nos diz pela própria organização de seus aspectos sensíveis. O real é este meio em que cada momento é não apenas inseparável dos outros, como também de alguma maneira sinônimo dos outros, nos quais os aspectos se significam uns aos outros em uma equivalência absoluta: impossível descrever completamente a cor do tapete sem dizer que é de um tapete, de um tapete de lã, e sem envolver nessa cor um certo valor táctil, um certo peso, uma certa resistência ao som. A coisa é este gênero de ser no qual a definição completa de um atributo exige a do sujeito inteiro e em que, por conseguinte, o sentido não se distingue da aprência total (PhP, p. 373). 
O importante para o filósofo é destacar como cada objeto visado pela consciência estaria em vizinhança a outros objetos (num horizonte de objetos) e cada ato perceptivo se dirige a um objeto com horizonte de reenvios, que a cada instante pode ser atualizado por outras percepções ${ }^{16}$. Isto leva Merleau-Ponty a dizer de um paradoxo entre imanência e transcendência (PP, p. 49), que é a experiência mesma do ato perceptivo, aliás, a própria ambigüidade que exprime nossa existência (PhP, p. 383): imanência, uma vez que o percebido não pode e não poderia ser obscuro àquele que percebe: está aqui, na minha frente. Posso tocá-lo; vê-lo; alisá-lo. Ao mesmo tempo, há uma transcendência, já que a coisa comporta sempre num além do que está imediatamente dado: está no domínio do possível (e no interior de um sistema de relações). Noutras palavras, uma presença irrecusável e uma ausência prepétua no horizonte de percepção (PhP, p. 270).

Mas há algo que fundamenta esta rede de reenvios: as coisas estão aqui na minha frente e quando tomo consciência que estou percebendo, na verdade, já as percebi, já vi estas cores ao meu redor. Mesmo que não me desse conta de estar percebendo, me "flagro" explorando o mundo ao meu redor. A grosso modo, isto significa que existe uma espécie de síntese que é realizada sem um ato expresso do eu, que se dá temporalmente e sem que eu tome qualquer decisão. Isto é fundamental, porque nega a suposta primazia do ato constituinte da consciência.

Trata-se de uma “síntese passiva” (PhP, pp. 479; 488), entendida não como uma passividade da consciência, mas uma síntese que está sempre em transição (PhP, pp. 307; 381; 480; 484; PP, p. 48): os perfis não se sucedem ou se justapõem, cada perspectiva passa na outra. Ou seja, trata-se da própria efetivação da visão (PhP, pp. 431-432).

\footnotetext{
${ }^{16}$ Aliás, esta é uma lógica que Merleau-Ponty amplia a vários níveis: os sentidos se reenviam, sem serem exatamente transponíveis objetivamente (PhP, p. 260), mas num "sistema de equivalências" (PhP, p. 271). Ou ainda: a percepção reenvia à minha posição num campo perceptivo, num sistema rigorosamente ligado entre corpo e mundo (PhP, p. 350). Ou: há uma correlação entre a percepção e o percebido onde ambos estão numa mesma modalidade existencial (PhP, p. 429). E mesmo no entendimento do mito ou do sonho, onde cada elemento reenviaria a outros (PhP, p. 338).
} 
Entretanto, esta questão está no seio da fenomenologia genética apontada por Husserl: algo que persegue a história da objetivação (a história do próprio objeto enquanto objeto de um conhecimento possível) e que nos reconduz ao que possibilita a existência de objetos. Isto nos leva a pensar não só que a síntese perceptiva se valha da nossa "perspectiva espacial” como de uma "perspetiva temporal”, pois, "para perceber uma superfície, por exemplo, não basta visitá-la, é preciso reter os momentos do percurso e ligar um ao outro os pontos da superfície” (PhP, p. 279). Ou seja: há uma co-presença ou uma co-existência dos perfis que se atam através do espaço e tempo (PhP, pp. 380-381), porque cada perfil dado me reenvia indefinidamente a outras persperctivas, operando no tempo (PhP, p. 381). Participemos um pouco deste problema.

Em Ideen...I, Husserl (1950, § 81) dizia de um problema complexo que ali não poderia trabalhar: a consciência do tempo, um absoluto último que possibilitava as sínteses perceptivas. Husserl dizia então que era preciso pensarmos numa intencionalidade originária do tempo (ou intencionalidade operante, como destaca Merleau-Ponty (PhP, p. p. xiii)): se há um "presente vivo" é porque este presente inclui um passado imediato e um futuro próximo. Quando vejo esta luminária na minha frente, por exemplo, sei que ela me remete a algo não presente, assim como me promete se dar de um outro modo. Se o dado me reenvia ao nãodado, do mesmo modo o agora me reenvia ao passado e ao futuro (a um fundo temporal (HUSSERL, 1994, § 25)). Seria como se a consciência atual de um objeto permanecesse operando na sua multiplicidade de aparições: como se cada fase passada estivesse em operação na fase atual por modos de doação diferentes deste passado. Trata-se de investigar assim como uma multiplicidade de fenômenos poderia ser a apresentação de um objeto idêntico no fluxo da experiência (MOURA, 2001, P. 170): como se todos os momentos pudessem se entrelaçar sem jamais serem o mesmo momento. 
Diferentemente da noção clássica, este presente vivo não poderia comportar instantes pontuais e descontínuos, como um “agora”. Husserl nos abriria então a um "presente ampliado”, que envolve uma quase presença do passado imediato e do futuro próximo:

a percepção me dá um 'campo de presença' [Husserl] no sentido amplo que se estende segundo duas dimensões: a dimensão aqui-e-ali e a dimensão passado-presente-futuro. A segunda faz compreender a primeira. Eu 'possuo', 'tenho', o objeto distante sem posição explícita da perspectiva espacial (grandeza e forma aparente) como eu 'ainda tenho em mãos' o passado [Husserl] próximo sem nenhuma deformação, sem 'recordação' interposta. Se ainda se quer dizer de síntese, ela será, como disse Husserl, uma 'síntese de transição', que não religa as perspectivas discretas mas que efetua a 'passagem' de uma a outra (PhP, P. 307).

Lembremos, por exemplo, que Husserl (1969, § 19) afirmava, nas Cartesianische Meditationen, que existia uma “síntese de identificação” que possibilitava uma ligação entre os estados de consciência aos estados vividos que escoam numa unidade de uma síntese de um mesmo objeto. Trata-se daquela "síntese passiva” que dizíamos, onde não se envolve nenhuma atividade expressa do ego, operada no próprio movimento do tempo "interno" da consciência. Cada percepção seria assim algo como um entrelaçar de um presente, com retenções (Retentionen) e protensões (Protentionen) (HUSSERL, 1994, p. 139; PhP, p. 83), e que tornaria possível as sínteses perceptivas (já que o próprio horizonte temporal garante a unidade do objeto). Moura é novamente claro nesta passagem:

se existe um 'mundo da experiência', se sistematicamente o 'dado' remete ao 'visado', se a presença se reporta à ausência, é porque o momento impressional do 'agora' reenvia ao passado e ao futuro por meio destas intencionalidades originais que são a retenção e a protensão (MOURA, 2001, p. 380).

No limite, isto quer dizer que o futuro, o passado e o presente participam de uma mesma unidade em cada ação (num campo de presença). Mas o passado não é o passado “em pessoa”, mas tal como eu o vejo agora, assim como o futuro em intenção. É como se, a cada momento, um mesmo fato acontecido no passado só permanece operando como um perfil do presente. Sendo assim, ele sempre está presente diante de uma modificação: diante de um presente atual. Isto porque é sempre o atual que está em vista ao possível: os atos da 
consciência sempre visando relações entre si a partir de um campo de presença — relações temporais que penetram num certo antes e num certo depois que o circundam.

Isto é fundamental a Merleau-Ponty: é no presente vivo (PhP, p. 485) que é possível qualquer síntese perceptiva. Isto nos levará a compreender, primeiramente, a definição da própria percepção:“(...) a percepção é meu poder concreto sobre o tempo em um presente vivo” (PhP, p. 391). Também reforçará a tese merleau-pontyana da primazia da consciência perceptiva diante dos outros modos de consciência, pois, na percepção, há uma doação originária da coisa: o objeto está em proximidade, presente, “em carne e osso”: “(...) é em termos temporais que se deve compreender o privilégio da percepção em face dos outros atos da consciência, bem como a raiz da diferença que a separa da consciência de imagem ou signo” (MOURA, 2001, PP. 377-378).

\section{4) O sujeito de percepção}

De um modo geral, podemos perceber que a principal caraterística que podemos apontar da consciência perceptiva é, em Merleau-Ponty, sua encarnação: é o corpo o sujeito de percepção (PhP, p. 260), pois, “se o sujeito está em situação, se ele não é nada senão uma possibilidade de situações, é que ele só realiza a sua ipseidade sendo efetivamente corpo e entrando por esse corpo no mundo” (PhP, p. 467). Vale aqui o apontamento de Marcel (1935, p. 12): “eu sou meu corpo”.

É certo que Merleau-Ponty reconhece a "encarnação" como o tema central da “filosofia da existência” (PE, p. 254). No entanto, Merleau-Ponty aprofunda esta idéia ao desenvolver o modo como nos relacionamos diretamente com o mundo como um modo corporal: estamos engajados no mundo de um modo concreto. Isto nos revelará que "nossa 
experiência desta unidade viva de nós mesmos e do mundo se concentra, como em sua origem e sua manifestação mais original, na experiência do corpo próprio”, como afirma Geraets (1971, p. 179). Será por isso que, no próximo capítulo, pensaremos neste engajamento com o mundo. Destacarei, portanto, que: “(...) meu corpo como subjetividade faz um com minha existência como corpo e com a existência do mundo e, finalmente, o sujeito que sou, concretamente tomado, é inseparável deste corpo-aqui e deste mundo-aqui” (PhP, p. 467).

Mas é bom salientarmos que, não só esta síntese depende de nossa situação corporal, como é o corpo que realiza esta síntese corporal: "não é o sujeito epistemológico que efetua a síntese, é o corpo” (PhP, p. 269). Ou ainda: “em cada movimento de fixação, meu corpo ata em conjunto um presente, um passado e um futuro, ele secreta tempo (...). Meu corpo toma posse do tempo, ele faz um passado e um futuro existirem para um presente, ele não é uma coisa, ele faz o tempo em vez de padecê-lo” (PhP, p. 277). Este comentário de Hyppolite (1961, p. 234) é significativo neste sentido: “meu corpo é ele mesmo a intencionalidade operante (...)”.

Isto significa dizer, entre outras coisas, que as sínteses da percepção ${ }^{17}$ são, antes de tudo, sínteses corporais (PhP, p. 269): “Husserl avança a idéia de uma síntese de transição (Übergangssynthesis). Nós efetuamos com nosso corpo a transição; é o ich kann” (HNN, p.221). Isto nos ficará claro se lembrarmos, por exemplo, que a percepção só nos é dada por perfis: a síntese que posso fazer de cada objeto só pode acontecer se meu movimento corporal tiver um papel nesta consciência perceptiva: “os movimentos do corpo próprio são naturalmente investidos de uma certa significação (...)” (PhP, p. 59). Além do que, “a percepção é a síntese de todas as percepções possíveis; essa síntese é realizada pelo poder que possuo de me deslocar” (Sorb, p.542). Na verdade, Merleau-Ponty insiste nesta idéia: “a consciência perceptiva não é uma alquimia mental, ela é global, total. O ich kann é o poder de

\footnotetext{
${ }^{17}$ E por isso também sínteses temporais, porque todas as nossas experiências se dispõem no tempo (PhP, p. 469).
} 
organizar alguns desdobramentos de aparência perceptiva a cada passo” (HNN, pp. 220-221). Waelhens (1968, p. 181) comenta:

enfim, o olhar é presença ou presente, porque seu desenvolvimento supõe e promete a mobilização de todos os poderes do corpo. É o corpo que, de uma só vez, se compreende e se reune no ato de fixar o quarto ou qualquer de seus objetos. Esta mobilização dos poderes sensíveis na síntese corporal (...) é a presença originária, porque ela é, originalmente, a instauração da coexistência.

É neste sentido que devemos pensar o movimento corporal ou a consciência enquanto “eu posso”, porque meu corpo é um “sistema de potência perceptiva” (PhP, p. 367). Faremos isto no terceiro capítulo. Isto nos levará a compreender que o corpo dispõe de uma generalidade em toda relação com o mundo, algo fundamental para compreendermos o modo como nos relacionamos com o mundo, com os outros e conosco mesmo. Com isto em mãos, poderemos descrever, brevemente, uma presença continuamente presente de si para si, que se articula com a generalidade corporal. 


\section{Segundo capítulo - Ser no mundo}

\section{1) Um modo de relação com o mundo: uma coisa diante de outra}

É interessante notarmos como Merleau-Ponty parece partir de um fato para afirmar nossa inerência ao mundo. Basta para isto notarmos que, quando dizemos de uma consciência perceptiva (o modo como nos relacionamos diretamente com o mundo), dizemos de um sujeito situado no mundo - é impossível conceber um sujeito sem mundo (PhP, p. 379). O sujeito está sempre numa situação concreta para o filósofo, de modo que o sentido de qualquer experiência já pressupõe nossa inerência ao mundo.

Neste sentido, não há dúvida ao filósofo: “o corpo próprio está no mundo como o coração no organismo" (PhP, p. 235). Como observa Ferraz (2006, p. 73), não se trata de questionar as condições de possibilidade da experiência, mas tomar como tema $o$ fato da experiência com o mundo. O “diagnóstico” é simples: “(...) o sujeito que eu sou, tomado concretamente, é inseparável deste corpo aqui e deste mundo aqui” (PhP, p. 467). Certamente, isto é algo que ninguém em sã consciência pode negar. $O$ que não é óbvio é o modo desta aderência do corpo ao mundo. É este modo que Merleau-Ponty tenta descrever: este corpo que vivo, que me acompanha, que habita o mundo numa adesão cega (PhP, p. 294), num pacto com ele ( $\mathrm{PhP}, \mathrm{p} .293)$.

Uma primeira abordagem desta relação nós podemos acompanhar pelas teorias de inspiração clássica. O desafio de Merleau-Ponty é mostrar como há uma incoerência em pensarmos um modo relacional partes extra partes. Por exemplo, poderíamos pensar a nossa aderência corporal com o mundo a partir desta relação: como uma coisa diante de outra (PhP, 
pp. 106-109). Certamente esta proposta não tem sentido aos olhos do filósofo: como pensar que meu corpo é uma coisa assim como esta tela na minha frente? É como negar que vemos o mundo “daqui”, com este corpo que "insiste” em permanecer ao meu lado ( $\mathrm{PhP}$, p. 106). Além do que, meu corpo é algo que só posso ver fragmentariamente: nunca fui capaz de inspecioná-lo por inteiro, tal como inspeciono, por exemplo, esta tela na minha frente. Posso rodear esta tela, vê-la em suas infinidades de perspectivas: de longe, de perto, enquanto só vejo "fragmentos" de meu corpo (as minhas mãos, que se deitam sobre este teclado, minhas pernas, que se cruzam nesta cadeira). Jamais serei capaz de rodeá-lo, ou de ver minha face, senão através da imagem de um espelho que tenho em meu banheiro: ali sei que posso ver meu rosto. Posso até fazer um jogo de espelhos para conhecer minhas costas, mas a presença de minha imagem ali apenas me remete à presença corporal aqui neste "pedaço" de mundo que é totalmente diversa da presença desta tela.

Uma análise aparentemente tão banal leva o filósofo a uma conclusão profunda:

a permanência do corpo próprio, se a psicologia clássica a tivesse analisado, poderia a conduzir ao corpo não mais como objeto do mundo, mas como meio de nossa comunicação com ele, ao mundo não mais como soma de objetos determinados, mas como horizonte latente de nossa experiência presente sem cessar, ele também, antes de todo pensamento determinante (PhP, p. 109).

Tomemos outro exemplo: o tocar das minhas mãos, uma na outra (PhP, p. 109). Na verdade, esta análise é de Husserl: ao tocar uma na outra, cada uma se “descobre” como seres tocantes e tocadas. Isto para Husserl (1969, § 44) queria dizer que sou essencialmente um corpo que sente e é sentido, tornado possível pelo fato de que a todo o momento "eu posso" perceber uma mão “por intermédio” da outra.

Este fenômeno, também aparentemente simples, demonstra novamente, para MerleauPonty, como o corpo não pode ter o mesmo estatuto de “objeto” de um corpo físico. No curso do Collège de France, podemos ver isto em toda sua profundidade:

quando toco minha mão esquerda com minha mão direita, minha mão tocante apreende minha mão tocada como uma coisa. Mas, de súbito, dou-me conta de que minha mão esquerda começa a sentir. As 
relações se invertem. Fazemos a experiência de um recobrimento entre a contribuição da mão esquerda e da mão direita, e de uma inversão de suas respectivas funções. Essa variação mostra que se trata sempre da mesma mão. Como coisa física, ela continua sendo sempre o que é e, no entanto, é diferente segundo for tocada ou tocante. Assim eu me toco tocando, realizo uma espécie de reflexão, de cogito, de apreensão de si por si. Em outras palavras, meu corpo torna-se sujeito: ele se sente. Mas trata-se de um sujeito que ocupa espaço, que se comunica consigo mesmo interiormente, como se o espaço se pusesse a conhecer-se interiormente. Deste ponto de vista, é certo que a coisa faz parte do meu corpo. Há entre eles uma relação de co-presença. O meu corpo aparece como 'excitável', como 'capacidade de sentir’, como ‘uma coisa que sente’ (N, pp. 107-108).

Esta experiência nos conduz a uma ambigüidade na idéia de sujeito-objeto, ou a um certo tipo de "reflexão corporal”, pois sinto minha mão ao mesmo tempo em que toco e que sinto ser tocado. Esta ambigüidade não poderia ser explicada pela lógica do pensamento objetivo, uma vez que se diz de uma “sensação dupla” onde não sei mais o que toca e o que é tocado (numa organização ambígua) (PhP, p. 109).

Uma conclusão óbvia é esta: se dissermos que há um sistema espacial entre minhas mãos e estas teclas, não posso dizer, no entanto, que há esta mesma relação entre o meu chapéu e o meu cabide, já que minha própria experiência me denuncia esta incompatibilidade. Se o homem fosse uma coisa entre as coisas, ele seria “(...) como esta cadeira ou como esta mesa, fechado em seus limites, presente num certo lugar do espaço e incapaz de se representar. É preciso lhe reconhecer um modo de ser bem particular, o ser intencional, que consiste em visar todas as coisas e não habitar nenhuma” (QE, p. 89).

Para onde isto aponta?

\section{2) Um comércio originário}

Lembremos primeiramente como Heidegger (2001, § 12) propunha um modo de relação interessante entre o Dasein e seu ao redor: ao relacionar "eu sou/estou” (Ich bin) com “ser com” (Sein bei), o filósofo “abria”, numa análise existencial, uma possibilidade de 
relação não mais de uma coisa com outra, mas de um ser aberto ao mundo, que está ao seu lado (Sein bei der Welt), cuidando dele (Aufgehens) e não diante dele.

A proposta de Heidegger (2001, § 13) é que há um comércio originário do Dasein com o seu a redor: uma relação pré-teorética, que não pode ser posta senão numa relação de abertura com o mundo. É por isso que o filósofo afirma um ser no mundo (In-der-Welt-sein).

Não escapa a Merleau-Ponty esta proposta heideggeriana. É esta a definição de existência: ser-no-mundo (être au monde) (PhP, pp. 414-415). Por quê?

Porque dizer que somos um ser no mundo é o mesmo que dizermos que somos/estamos "situados” num mundo de modo concreto, num comércio originário com este mundo “pré-objetivo" (PhP, pp. 94-94). Isto significa que o sujeito merleau-pontyano é um sujeito aberto ao mundo (PhP, p. 344), numa relação anterior a qualquer determinação que poderíamos fazer dele: “estou aberto ao mundo, comunico-me indubitavelmente com ele, mas não o possuo, ele é inesgotável” (PhP, pp. xi-xii).

Entretanto, se para Heidegger isto lhe levava a pensar principalmente no modo de ser do Dasein enquanto ser no mundo, para Merleau-Ponty, "estar aberto ao mundo" significa, antes de tudo, pensar esta relação enquanto uma relação corporal, pois é o corpo que está engajado no mundo, ao seu lado, antes mesmo de determinarmos este fato. Isto é fundamental para o filósofo: é pelo corpo que o mundo é dado a ser vivido por mim, pois “o corpo é o veículo do ser no mundo; ter um corpo é, para um ser vivo, juntar-se a um meio definido, se confundir com certos projetos e se engajar neles continuamente” (PhP, p. 97).

Mas o que significa exatamente estar aberto ao mundo? Um exemplo: bastaria aqui dizer que o "homem possui um Umwelt”?

É o próprio Heidegger (2001, § 12) quem aponta e protesta esta formulação, pois isso não indica inteiramente o problema do In-der-Welt-sein. Esta formulação biológica, divulgada 
principalmente por Baer e Uexküll, não parece dizer o fundamental: o que significa este "possuir"?

É certo que Uexküll (1988, passim), por exemplo, nos leva a pensar numa relação de cada organismo com seu meio, segundo uma totalidade concreta, cujo conjunto de excitações é tomado ativamente por este organismo num meio que, para si, tem uma significação. É possível assim dizer que cada ser vivo tem um “mundo próprio”, mesmo vivendo num ambiente em comum, revelando uma ordenação da estrutura de cada organismo em relação ao meio que lhe circunscreve. Mas ainda assim, Uexküll não aponta o que significa esta relação: ele não explicita a significação do problema do "comércio originário" com o mundo. Antes, o pressupõe.

Tentemos então um outro exemplo: segundo Merleau-Ponty, o behaviorismo indicanos um caminho, pois além desta teoria ser contra a introspecção ou contra a consciência concebida como uma série de estados fechados em si mesmos, sua intenção era recolocar o sujeito em contato com o mundo (Sorb, p. 429). Seja descartando as referências do comportamento com a consciência e pensando a psicologia como uma ciência dos dados verificáveis experimentalmente, acaba por perceber que entre os estímulos e as reações há uma integração molar, isto é, uma relação do organismo com a totalidade do meio que deve ser levada em conta.

Lembremos que Koffka havia apontado dois modos de se tomar o problema comportamental:

1. como "molecular", isto é, tomando-o fragmentariamente, segundo as leis dos “elementos”;

2. como "molar" ou como um todo, em que só podemos distinguir um fragmento do comportamento com consciência de que este fragmento tem um outro sentido, outra “qualidade”” diferente do todo (KOFFKA, 1955, pp. 25-31). 
Se Watson buscava pensar o comportamento animal como molar, ao firmar, por exemplo, que “não interessa o que o animal está fazendo, ele o faz como um todo" (WATSON apud WOLMAN, 1960, p. 83), então ele empenhava-se em definir o comportamento num debate entre o indivíduo e o meio.

Há um grande mérito nisto, segundo Merleau-Ponty:

sob o ângulo molar, o comportamento não é explicável por fenômenos nervosos associados; define-se através do meio econômico, histórico; implica percepção de valores em relação com uma configuração cultural: assim é definida a situação da conduta. O comportamento assume um significado; já não se reduz ao conjunto não significativo de seus resultados (Sorb, p. 430). Ou ainda: o que me parece importante no pensamento americano é a idéia de comportamento (behavior). Os americanos entendem por isto o conjunto de nossas relações concretas com o mundo, que estão bem longe de se reduzirem, como acreditava a psicologia clássica, a relações de conhecimento. Para eles, o homem tem 'uma corrente de atividade’ em relação com seu meio: ele está enraizado na natureza e na história (MPM, p. $67)$.

Entretanto, este debate existencial acaba se furtando numa “causalidade”, voltando-se aos fenômenos nervosos, numa "reflexiologia” ou numa "rede” de reflexos condicionados, segundo leis da teoria do learning, já encontradas em Pavlov (Sorb, p. 429). Agindo deste modo, o behaviorismo opõe-se ao conteúdo de sua doutrina (que esperava se afastar da fisiologia, em prol das significações da integração do organismo no meio, segundo as atividades que lhes corresponderiam). Como era de se esperar, o problema fundamental deveria se passar na relação interno/externo, mas terminar por se desenvolver numa "reflexologia” ou numa cadeia de reflexos condicionados, uma vez que sua metodologia poderia apenas se apoiar em dados observáveis no comportamento ${ }^{1}$. Nestes termos, impôs-se a si mesma a tarefa de interpretação físico-química dos problemas comportamentais às aquisições da conduta animal (que só pode se traduzir em termos de fenômenos do sistema nervoso, muito próximo das interpretações pavlovianas da fisiologia).

\footnotetext{
${ }^{1}$ Lembremos que este problema era, aliás, algo fundamental na crítica merleau-pontyana ao behaviorismo. Ora, o ideal de objetividade watsoniano, consistindo em pensar a psicologia apenas a partir dos fatos reais, levava-o a acusar a observação dita "direta” do comportamento como uma observação subjetiva, ou uma interpretação “antropomórfica” dos dados. Mas para Merleau-Ponty este ideal é uma “quimera” (Sorb, p. 433), já que todo dado só pode ser apreendido a partir de uma situação humana. Não seria "matematizando" os dados que iríamos "escapar” do ponto de vista em situação: "não é o antropomorfismo que se exclui, mas a ciência — não é a objetividade que se defende, é o realismo e o nominalismo" (SC, p. 112). Aliás, de um modo geral, esta também foi a crítica de Köhler ao behaviorismo (KÖHLER, 1947, pp. 7-23).
} 
Se não basta pensarmos num Umwelt, nem numa integração molar, como pensarmos o sentido desta abertura ao mundo?

\section{3) Um “poder" de situar-se no possível: a diferença entre o comportamento humano e o comportamento animal}

Um outro caminho é indicado pela Gestalttheorie. Parece-me que Merleau-Ponty encontra já em La Structure du Comportement um outro modo de pensar aquela abertura: de buscar o sentido de "um certo modo de tratar o mundo, de 'ser no mundo' ou de 'existir'” (SC, p. 136), sem reduzir isto a um Umwelt. Para entendermos isto, é preciso compreender como se dá a busca do sentido da distinção de formas de comportamentos entre as ordens física, vital e humana. Isto é muito importante, uma vez que, se era possível a Merleau-Ponty destacar que há diferentes níveis comportamentais, como, por exemplo, a diferença entre o comportamento humano e o comportamento animal, mesmo que possamos especificar o Umwelt de cada um, então é o próprio sentido, o próprio comércio com o mundo que está em jogo.

Antes de mais nada, é importante a Merleau-Ponty destacar como esta diferenciação entre ordens não poderia ser pensada como uma diferenciação substancial. Ou seja, diferentemente da Gestalttheorie, não poderíamos dizer de uma "realidade física”” para além da nossa percepção (SC, p. 151), fora de nosso contato com o mundo (PhP, p. 24). Certamente Merleau-Ponty protesta contra isto: a forma é uma “significação”, e não “uma realidade física, mas um objeto de percepção, sem a qual, inclusive, a ciência física não teria sentido, porque

\footnotetext{
${ }^{2}$ Por exemplo: "pode-se dizer que esse caráter de solidez a que acabei de me referir ocorre apenas como um atributo de coisas isoladas. Pertence, evidentemente, à classe geral das qualidades de Ehrenfels. Alguns psicólogos poderão inclinar-se a atribuir esse caráter a experiências tácteis que adquirimos ao manejar os objetos físicos, mas não há nenhum motivo particular que nos impeça de considerá-lo um atributo das coisas visuais em si mesmas” (KÖHLER, 1947, p. 120).
} 
ela é construída em vistas dela e para coordená-la” (SC, p. 155) ${ }^{3}$. Isto é importante ao filósofo, senão restauraríamos na Gestalt o mesmo problema que se buscava superar: fazer da Gestalt uma coisa, enquanto ela é apenas um fenômeno de organização, um tipo de estrutura (Sorb, p. 263).

Outro problema a se evitar é certamente o do “isomorfismo" proposto pelos gestaltistas (KOFFKA, 1955, pp. 53-67), pois, ao pensar um “isomorfismo” entre o campo comportamental e o campo fisiológico (KATZ, 1967, p. 60), os gestaltistas acabaram reduzindo as estruturas biológicas e psíquicas ao campo físico comportamental. O resultado é que as nossas experiências e os nossos processos nervosos teriam as mesmas estruturas.

O que Merleau-Ponty propõe é pensar a ordem correlativa a cada domínio, sem que, com isso, se fizesse uma divisão substancial. "Em outros termos, matéria, vida e espírito devem participar desigualmente à natureza da forma, representar diferentes degraus de integração e constituir, enfim, uma hierarquia onde a individualidade se realiza sempre primeiramente” (SC, p. 143). Sendo assim, a cada ordem corresponderia um certo tipo de forma: sincrética, amovível e simbólica (SC, p. 113), respectivamente, sem que haja nelas uma ruptura entre níveis categoriais e, sim, uma distinção “organizacional”.

É certo que nem todos os animais poderiam agir nestes níveis, pois o problema é da organização estrutural possível do organismo em relação ao meio. Tratar-se assim, no primeiro caso, das atividades adaptadas do organismo em seu meio ambiente: do comportamento adaptado diante das situações concretas. A segunda forma tornaria apto o organismo a entender certas relações e analogias, reconhecer símbolos, e a se adaptar a situações inéditas, sem ainda conseguir abstrair-se de sua própria situação “material”. Isto significa que seria possível um certo tipo de abstração, mas sem se colocar numa situação fictícia.

\footnotetext{
${ }^{3}$ Ou, como nos diz Buytendijk (1965, p. 23): “nós devemos antes de tudo nos dar conta de que tudo o que saber dos fenômenos na natureza animada e inanimada repousa sobre a percepção”.
} 
Os gestaltistas, por exemplo, nos mostram como os chipanzés são capazes de um certo tipo de imitação (KÖHLER,1959, pp. 165-200), que certas aves reagem a algumas configurações” (KÖHLER, 1947, pp. 85-89), ou que elas estão sujeitas às figuras de Jastrow (KOFFKA, 1955, p. 90). É possível afirmar, então, um certo “poder” do animal em se adaptar a "estruturas significativas”, reagindo com uma certa ordem aos signos sugeridos na relação com o meio (Sign-Gestalt) (SC, p. 116).

Mas as observações de Köhler (1959, pp. 241-293) nos deixam também claro que os chipanzés agem de um ponto de vista diferente do nosso, pois, mesmo que o objeto tenha um valor "funcional” na ação, segundo a efetividade do seu campo de ação, não há, como na criança, um "poder" de situar-se no possível, ou num outro ponto de vista, ou ver um objeto sob aspectos diferentes. Por exempo: um banco pode ser ora algo para se sentar, ora algo para se conseguir alcançar outra coisa, ora um lugar para se apoiar, dependendo do ponto de vista que o animal se coloca e de suas várias funções possíveis. Isto se explica porque os chipanzés não criam "pontos de vista”, mas seguem um, numa determinada situação: “ele não pode variar os pontos de vista, como ele não poderia reconhecer uma mesma coisa em diferentes perspectivas” (SC, p. 128).

É, portanto, no homem que poderíamos afirmar uma forma simbólica. É aí que seria possível ao organismo transcender à situação atual, projetar-se ao "não acontecido”, a uma outra realidade possivel, possibilitando-o transcender temporalmente (apesar de estar de certo modo presente). É nessa forma de comportamento que a intenção é fundamental e as possibilidades são abertas, uma vez que a ficção é plenamente possível (SC, p. 133). Era exatamente isto que Goldstein (1939, p. 392) protestava dos gestaltistas ao isomorfismo: como seria assim possivel o atributo especificamente humano: the attitude towards the Possible? 
É esta "possibilidade", este "poder de virtualidade”, o fundamental. É por isto que Merleau-Ponty faz questão de nos mostrar que o comportamento humano é solidário ao reino do possível. É este o sentido da “abertura ao mundo" ou o modo próprio humano de freqüentar o mundo: o homem não só tem um mundo, como diz Uexküll, não só está numa relação molar, como sugerem os gestaltistas e o behaviorismo, mas está aberto a um mundo pelo poder que tem de agir sob ele de modo possível: o que importa é o modo que se faz o uso do corpo, pois o “equipamento psicofisiológico” deixa abertas várias possibilidades (PhP, p. 220). Vejamos agora como esta idéia é fundamental em Merleau-Ponty, mesmo que ele tenha apontado isto muito brevemente em La Structure du Comportement.

\section{4) Conduta possível e conduta concreta: o normal e o patológico}

Esta mesma questão aparece na Phénoménologie de la Perception de um modo interessante. Trata-se de diferenciar dois tipos possíveis de comportamento: um voltado ao concreto e outro voltado ao possível. Merleau-Ponty parte de um exemplo de Goldstein. Trata-se do “famoso” caso de Schneider.

O objetivo de Goldstein era diferenciar gestos que aparentemente poderiam ser sobrepostos, mas que no fundo demonstrariam uma diferença do sentido da conduta do doente em relação à conduta normal (Sorb, p. 437). O experimento é simples: tocamos no doente e perguntamos a ele onde foi tocado. Goldstein diz que Schneider não consegue apontar este lugar (PhP, p. 132), mas consegue, entretanto, reagir a uma picada de um mosquito (como bater a mão no lugar picado). A lição que podemos tirar disto é que há uma diferença clara entre uma conduta representacional (apontar o lugar picado) e uma conduta simplesmente corporal (reagir à picada). 
O que é interessante para Merleau-Ponty é a conclusão de Goldstein (1971, p. 49): Schneider não consegue transcender a situação dada, sendo incapaz de viver qualquer situação “possível”. Ora, se Schneider não consegue representar o espaço, é porque ele perdeu seu poder de representar, vivendo num espaço concreto, respondendo apenas à situação dada (PhP, pp. 128-129).

Haveria, então, dois tipos de movimento: um abstrato e outro concreto; um dado e outro construído (PhP, p. 128). "No movimento concreto, o doente não tem nem consciência tética do estímulo, nem consciência tética da reação: simplesmente ele é seu corpo e seu corpo é a potência de um certo mundo” (PhP, p. 124).

Para Merleau-Ponty, não se trata apenas de um diagnóstico clínico. Isto lhe permite dizer que o comportamento normal é um comportamento “voltado ao possível”, assim como buscava o sentido do modo relacional no reino do possível em La Structure $d u$ Comportement. O problema é o mesmo aqui: “o movimento abstrato cava, no interior do mundo pleno no qual se desenrolava o movimento concreto, uma zona de reflexão e de subjetividade, ele sobrepõe ao espaço físico um espaço virtual ou humano” (PhP, p. 130). No caso do doente, ele contaria apenas com um campo presente (PhP, p. 127), onde o “fundo" do movimento concreto é o mundo dado, enquanto que para o movimento abstrato, supõe-se um mundo “construído” (PhP, p. 128), “projetado” (PhP, p. 129), com função de “projeção” e “evocação” (PhP, p. 130).

Um modo de compreendermos isto melhor é evocando um livro contemporâneo à Phénoménologie de la Perception. Trata-se de Le Normal et le Pathologique, de Canguilhem. Para Canguilhem, o doente é doente, porque se estrutura de num modo unívoco, conseguindo seguir apenas uma norma específica de ação. Conseqüentemente, o doente não consegue transcender as oscilações do meio. Ele se apega a uma norma (CANGUILHEM, 2002, p. 148) e não é capaz de instaurar normas (CANGUILHEM, 2002, p. 163). A diferença entre o 
normal e o patológico estaria, assim, em relação à normatividade da vida. No primeiro caso, o sujeito poderia instaurar normas, transcendendo as configurações estáticas do meio: poderia agir segundo seus valores. No segundo, o sujeito estaria à mercê do meio, pois qualquer variação seria para ele catastrófica, pois o doente se orientaria segundo uma norma unívoca e não seria capaz de se pôr uma nova normatividade (CANGUILHEM, 2002, pp. 187-189). Uma conseqüência disto é que não há algo que seja normal e patológico em si mesmo: é na relação entre o organismo e o meio que poderíamos distinguir uma conduta normal e uma conduta patológica.

Percebamos quão próximos estamos de Goldstein: o doente depende do mundo exterior, "isto acontece de modo anormal, de modo compulsivo, ele é perturbado muito facilmente por mudanças em eventos externos” (GOLDSTEIN, 1971, P. 62).

Isto é também bem próximo do que dizíamos de Merleau-Ponty: o sujeito normal é aquele que é capaz de se pôr em diferentes situações, orientações, seguindo uma “virtualidade”. Já o sujeito doente é um sujeito que se fixa num comportamento concreto e que perde seu poder de virtualidade: nada é presente a ele senão aquilo que lhe é imediatamente dado (PhP, pp. 154-155) ${ }^{4}$. É assim que Schneider não consegue compreender o desenvolvimento de uma história que lhe contam, por exemplo: ele perdeu o poder de viver ou de se pôr nesta história (PhP, p. 154), do mesmo modo que perdeu o poder de vivenciar o sentido da fala do outro (PhP, p. 155).

Merleau-Ponty parece realmente ampliar esta idéia a vários casos. Por exemplo: na hemianopsia, seria a função de projeção que falta ao doente, “(...) a capacidade de orientar-se sobre o possível” (Sorb, p. 455). Trata-se do mesmo caso na relação com a linguagem: haveria uma linguagem concreta e uma linguagem categorial (GOLDSTEIN, 1971, p.73): por um lado, respondendo às situações efetivas; por outro, considerando a palavra como que uma

\footnotetext{
${ }^{4}$ Segundo Waelhens (1968, p. 125), esta problemátca está inserida no vocabulário heideggeriano: o sujeito doente é prisioneiro da Zuhanenheit, enquanto o normal está aberto à Vorhandenheit.
} 
entidade abstrata e que responderia assim antes às situações fictícias que às situações de demanda (Sorb, p. 60). Goldstein (1971, p. 60) pontua: “o indivíduo tem que considerar a situação de vários aspectos, tomar o aspecto que lhe é essencial e agir de modo apropriado a toda situação”. O mesmo acontece em Merleau-Ponty: o normal “(...) está aberto às situações verbais e fictícias que ele pode escolher ou que um experimentador pode lhe propor” (PhP, p. 126).

A própria psicanálise entra em seu jargão. Como no caso do "recalque” (PhP, p. 98): há como que uma certa via que incessantemente remete a um engajamento de fixação ou a um certo tipo de comportamento que não modifica sua estrutura. Poderíamos dizer de numa forma “típica” (PhP, p. 99) de comportamento que se “estrutura” segundo este "privilégio”, num mundo unívoco, ou numa "certa angústia” ( $\mathrm{PhP}$, p. 99) que não cessa de repetir a si mesma.

Para Merleau-Ponty, isto significa que o doente bloquearia o seu poder de se colocar em diferentes situações. Agiria como se não houvesse um outro modo de agir, vivendo num “mundo fixo” que jamais cessaria de repetir a si mesmo. Já “o normal conta com o possível que assim adquire, sem abandonar seu lugar de possível, um tipo de atualidade; no doente, ao contrário, o campo do atual se limita ao que é encontrado no contato efetivo ou religado ao dado por uma dedução explícita” (PhP, p. 127).

O mesmo se pode afirmar da sexualidade em Schneider. Ele está arraigado ao mundo concreto e "perdeu” seu poder de “projeção”, de se colocar numa "situação erótica” (PhP, p. 182): o mundo é “mudo” para ele porque não lhe situa numa relação de sexualidade, assim como para ele existe uma outra "familiaridade" com as coisas que parece ser diferente da “familiaridade normal”.

Na verdade, a meu ver, é possível a Merleau-Ponty ampliar este problema a vários casos, porque, para o filósofo, a essência mesma da consciência é se dar novos mundos, 
tomando outros pensamentos diante de si como possiveis (PhP, pp. 151-152): “a vida humana ‘compreende’ não somente tal meio definido, mas uma infinidade de meios possíveis (...)” (PhP, p. 377). Ou, como observa com precisão Geraets (1971, p. 163): “eu não estou somente 'em situação', eu me defino como 'possibilidade de situações' e, nesta medida, eu posso dizer de mim: 'Eu sou um campo, eu sou uma experiência' (...)”. Há assim como que uma "produtividade" do corpo que acompanha a idéia de um "poder" corporal, muito próximo do ich kann de Husserl, como veremos.

Entretanto, poderíamos questionar Merleau-Ponty de um modo bastante simples, que negaria toda esta teoria. Poderíamos perguntar: Schneider não sofre simplesmente de um déficit cerebral, como nos diria talvez um médico ou um fisiologista?

\section{5) Mudança qualitativa do comportamento}

Sabemos que, para Goldstein, dizer de um déficit cerebral significa "ver” o doente “negativamente”. Quer dizer, segundo o que “falta” para o sujeito agir normalmente. Qual o problema de pensarmos assim?

Dentre vários problemas levantados por Goldstein (que Merleau-Ponty acompanha em larga medida), um em especial deve ser destacado: deste ponto de vista, negar-se-ia que o organismo age como um todo, como uma "estrutura”.

O que Goldstein verifica é que, quando o sujeito adoece, ele não adoece uma parte de seu corpo, pois todo seu corpo se reestrutura a partir desta nova situação: há uma alteração qualitativa $^{5}$ da sua conduta. Não se trata assim de uma desintegração do sistema "préestabelecido", mas numa “reorganização estrutural do comportamento”, visando uma melhor

\footnotetext{
5 “(...) o organismo consiste em diferentes estruturas qualitativas” (GOLDSTEIN, 1939, p. 271).
} 
adaptação ou uma melhor "ordem” do sistema nervoso como um todo: “desde que nós estejamos considerando um sistema pelo qual sempre funciona como um todo, um estímulo deve produzir mudanças em todo o organismo” (GOLDSTEIN, 1939, p. 104).

Merleau-Ponty utiliza esta idéia em vários momentos de sua obra. Seja em La Structure du Comportement, seja na Phénoménologie de la Perception. Mas de um modo geral, seria interessante entendermos melhor o porquê desta "apropriação”.

O que primeiramente podemos apontar é uma questão de método, pois Goldstein, ao procurar reestruturar os feridos da primeira guerra mundial, começa os estudos a partir de casos reais, sem levar em conta nenhum "preconceito a priori”:

Goldstein não admite que nos apoiemos nesses preconceitos mecanicistas nem em preconceitos vitalistas. É só depois de um aprofundado estudo experimental que se chegará a definir a fisiologia e a vida. Não se pode saber o que é o organismo antes de ter tomado contato com ele; definir-se-á em seguida o ser fisiológico, depois de conhecê-lo em matéria de fisiologia. Ele procura definir um ser fisiológico em função do fenômeno tal como nos aparece (Sorb, p. 452) ${ }^{6}$.

Nada mais sugestivo a um fenomenólogo. Tratar-se-ia então de pensar a "lesão" ou a “doença” num sentido “positivo”, pois

a doença, assim como a infância e o estado 'primitivo’ são uma forma de existência completa (...). O verdadeiro método indutivo, não é um 'método de diferenciação', mas consiste na leitura correta dos fenômenos, em apreender seu sentido, quer dizer, em tratá-los como modalidades e variações do ser total do sujeito (PhP, p. 125).

Mas, no fundo, o fundamental é que, se por um lado tanto as análises do comportamento inferior e superior nos levavam a pensar o comportamento seguindo uma relação de exterioridade, a Gestalttheorie e Goldstein propunham uma relação de reciprocidade entre todo/partes. Quer dizer, a partir desta nova relação, seria possível pensar numa nova concepção do comportamento humano: pensá-lo como um todo, onde cada gesto reenviaria a outros ou expressaria os outros. Aliás, seria possível pensar em termos de

\footnotetext{
${ }^{6}$ Basta conferirmos os três métodos para determinação de um sintoma para Goldstein (1939, pp. 17-27): “1) considerar inicialmente todo fenômeno apresentado pelo organismo (neste caso pode ser um paciente), não dando preferência na descrição de nenhuma em especial. (...) 2) o segundo postulado metodológico consiste na correta descrição da observação do fenômeno em si mesmo. (...) 3) (...) nenhum fenômeno pode ser considerado sem referência ao organismo concebido, e ao estímulo em que aparece”.
} 
“estruturas”: todo o “corpo” está envolvido em qualquer de suas ações, agindo como a lógica gestaltista de figura/fundo (GOLDSTEIN, 1939, pp. 217-226):

a alegação de fenômeno 'isolado', da qual se alude ser o termo reflexo, é na verdade a 'figura' numa reação padrão de todo o organismo. O reflexo é a 'figura', enquanto que a atividade do resto do organismo é o fundo. Isto é claramente confirmado pelo fato de que qualquer mudança no restante do organismo modifica de uma vez o reflexo, a figura (GOLDSTEIN, 1939, p. 159; 1971, p. 12).

Isto possibilitava a Merleau-Ponty negar, por exemplo, a teoria reflexa do comportamento ao pensar a organização do sistema nervoso, partindo da Gestalttheorie:

nosso ponto de vista será que, em vez de reagir aos estímulos locais por meio de fenômenos locais e mutuamente independentes, o organismo reage ao padrão de estímulos aos quais será exposto, e que essa reação é um processo unitário, um todo funcional, que oferece, na experiência, uma cena sensorial e não um mosaico de sensações locais (KÖHLER, 1947, p. 62) ${ }^{7}$.

Isto indica que há uma reação unitária do organismo. Mas trata-se, antes de tudo, de pensar numa noção “estrutural do organismo”. Não é por menos que os estudos de Pavlov, por exemplo, deveriam ser “censurados” ali na La Structure du Comportement, pois, apesar deles se situarem no saber do como se deve compreender o organismo em relação ao meio (aliás, mais rico que aquele que age imediatamente sob a forma de estímulo físico e químico sobre as terminações sensoriais), estão mais próximos de uma construção de inspiração atomista de análise real do que de um novo modo de compreensão do comportamento. Um pequeno resumo nos ajudará a entender isto melhor.

Sabemos que Pavlov (1961, P. 389) propõe uma inovação da atividade nervosa superior ao dizer de um reflexo condicionado: uma ligação temporária superior, mais

\footnotetext{
${ }^{7}$ Ou ainda: “agora sabemos o que é o processo fisiológico molar. Ele não é a soma ou a combinação de processos nervosos locais independentes, mas os processos nervosos em extensão dependem para cada processo local de todos os processos locais com distribuição molar” (KOFFKA, 1955, p. 59).
} 
“elaborada” que o equilíbrio constante do organismo com o meio ${ }^{8}$. Mas este estado de equilíbrio ${ }^{9}$ se daria por leis mecânicas ${ }^{10}$ muito próximas da tese do comportamento reflexo.

A crítica vale para ambos: isto significava que há uma correspondência, ponto a ponto, do estímulo ao comportamento, mesmo que se pressuponham dois "níveis" de reflexo, e mesmo pressupondo que o reflexo incondicionado seja mais elaborado que a reação “incondicionada” do organismo: “a essência da atividade nervosa permanece a mesma: é um processo decomponível em partes reais” (SC, p. 55). Aliás, quando Pavlov esbarra com problemas na verificação experimental de sua teoria, parece “criar” leis e processos que tentam “corrigir” o problema sem nunca questionar se não é o próprio fundamento teórico que impossibilita a verificação experimental. Ora, para o fisiólogo, se não verificamos sempre uma mesma reação para um mesmo estímulo, é porque esta modificação do comportamento se explicaria por inibições e estimulações (já que só se pode pensar em processos isolados), e não na mudança “qualitativa” do comportamento.

Contrariamente a isto, Goldstein propõe que pensemos em termos de “estrutura”. Por exemplo: se tomarmos a localização do "setor central" do comportamento como guia, veríamos que, no caso da afasia, há uma reestruturação comportamental, uma mudança qualitativa no comportamento, o que sugere que as localizações cerebrais deveriam ser pensadas segundo o cérebro inteiro ${ }^{11}$. O que se tem em mente é mostrar que as interpretações

\footnotetext{
${ }^{8}$ Para Pavlov, há sempre esta pressuposição de um equilíbrio, constantemente estabelecido por "reflexos incondicionados" (porque quase sempre o meio é inconstante). Dever-se-ia assim ter um equilíbrio mais “completo” e “complexo” com o meio (PAVLOV, 1961, pp. 393-394.), por isso, de um reflexo temporário (até se re-estabelecer um equilíbrio).

9 Na verdade, Pavlov parece partir de uma concepção “ingênua” da natureza, como nos aponta Wolman: "ele acredita que os homens são parte da natureza, natureza esta sendo interpretada como a soma de matéria e energia.” (WOLMAN, 1960, p. 42). Conseqüentemente, ele aplica uma concepção mecanicista para os problemas causais: "ele subscreve a teoria do mecanicismo determinista e professa uma causalidade rígida, inviolável, necessária e inflexível no comportamento animal e humano” (WOLMAN, 1960, p. 43).

${ }^{10}$ O sistema nervoso seria como um sistema energético, com processos definidos e previsíveis de aquisição, descarga, estimulação, inibição, irradiação e concentração de energia, regulado por leis relativamente "simples". O organismo responderia assim às estimulações do mundo exterior tendendo a um constante equilíbrio, segundo os processos necessários para tal. Afinal, o reflexo seria o elemento interativo entre o organismo e o meio, sendo a função principal do sistema nervoso, por isso mesmo correspondente à função de "preservação da vida”.

${ }^{11}$ Aliás, para Merleau-Ponty, "nenhum autor sério renunciou à noção de localizações cerebrais, mas não se trata de uma relação do continente e conteúdo. Goldstein propõe a seguinte idéia: há duas verdades a se levar em
} 
das lesões cerebrais que ocasionam a perda da fala não estão ligadas diretamente a uma suposta perturbação do “órgão da fala”, como se houvesse um "lugar” que pudesse ser um centro de “imagens verbais”. Há, pelo contrário, uma mudança estrutural do organismo, quer dizer, uma mudança comportamental que se pode descrever na mudança de comportamento do “paciente”, mostrando-nos não uma “inibição” do sistema nervoso, mas uma reorganização qualitativa como um todo.

Em linhas largas, perder a habilidade do emprego do significado é uma mudança no nível da ação do sujeito: ele passa a agir segundo uma atitude concreta e não mais categorial (numa linguagem concreta). Mas isto não significa que o doente perdeu o uso da fala, mas apenas um certo tipo de linguagem (Sorb, p. 60; GOLDSTEIN, 1971, pp. 69-84), cujo papel é responder às situações imediatas: “(...) nossos pacientes não perderam realmente as palavras. Ao invés disto, as palavras perderam suas características de serem usadas como abstração, e esta mudança na linguagem é apenas uma expressão de uma mudança básica em nossos pacientes: a perda da capacidade de criar qualquer tipo de abstração" (GOLDSTEIN, 1971, p. 79).

O sujeito normal, por outro lado, considera a palavra como uma entidade abstrata, respondendo às situações no reino do possível (o que nos mostra certamente uma certa produtividade da linguagem (Sorb, p. 63)): “nossa conclusão é que a incapacidade do paciente de nomear objetos é uma conseqüência de sua incapacidade de assumir a atitude abstrata, pois isto é pré-requisito para a nomeação de objetos. (...) O paciente não perde as palavras em si mesmas, mas é incapaz de usá-las em situações que pedem seu uso como categorial” (GOLDSTEIN, 1971, p. 76).

conta: o cérebro inteiro contribui para cada operação parcial, logo não há funcionamento em mosaico.” (Sorb, p. 62). 
O que se está descrevendo nesta mudança comportamental é, no fundo, uma mudança na estrutura do organismo ${ }^{12}$. Merleau-Ponty encontra assim nos trabalhos de Goldstein (e também de Gelb) características estruturais que possam levar a um re-pensar da teoria clássica, pois

fica claro aqui que a doença não é concebida diretamente pelo conteúdo do comportamento, mas por sua estrutura (...). A condução da doença não se deduz pela conduta do normal por simples subtração de partes, ela representa uma alteração qualitativa (...). Aqui aparece então um novo gênero de análise que não consiste mais em isolar os elementos (...) (SC, p. 70)

\section{6) Uma atividade orientada}

Há ainda uma outra característica do sujeito normal para Merleau-Ponty que não poderíamos deixar de acompanhar aqui: "quem diz comportamento diz atividade orientada: na medida em que a conduta perde seu objetivo definido, nós podemos então dizer de um fracasso ou de uma conduta patológica, e afirmar a existência de uma distinção entre o normal e o patológico” (Sorb, p. 56).

Antes de mais nada, é importante frisar que isto indica que o corpo é um sistema de ações possíveis (PhP, p. 289): “um corpo virtual cujo 'lugar’ fenomenal é definido por seu objetivo e pela sua situação” (PhP, p. 289).

Isto significa afirmar, entre outras coisas, que o sujeito não está submetido às ações físicas, como no caso do doente que está à mercê do meio, “cego” ao meio em que vive. O

\footnotetext{
${ }^{12}$ Eis toda a tese de Goldstein sobre este ponto: “a localização da performance não mais significa para nós uma excitação num certo lugar, mas um processo dinâmico com ocorrência em todo o sistema nervoso, mesmo em todo o organismo, e na qual tem uma configuração definida para cada performance ["chamamos de performance num organismo qualquer tipo de atividade comportamental, ou operação do todo nas partes, pela qual expressase abertamente e que se refere ao meio comportamental” (GOLDSTEIN, 1939, p. 28)]. Esta configuração da excitação tem, numa certa localidade, uma especial formação ('elevação'), correspondendo ao processo de figura. Esta elevação encontra sua expressão na figura da performance. Uma específica localização é caracterizada pela influência com a estrutura particular da área que exerce no processo total, i.e., pela contribuição da qual a excitação da área, por causa da sua estrutura, faz ao processo total” (GOLDSTEIN, 1939, pp. 260-261).
} 
sujeito tem uma certa capacidade de instaurar normas, como diz Canguilhem, ou de ir em direção ao possível, como diz Merleau-Ponty: ele é capaz de “definir” suas condições ou de afirmar um certo tipo de orientação nos movimentos, um certo tipo de escolha (sem depender tanto, como no caso do doente, das variações do meio): “perceber é se orientar em direção a uma coisa, visá-la. Agir é pôr, num movimento, uma intenção dotada de sentido. Isto exige que o conhecimento seja um 'modo de comportar em vistas de...' e que a ação seja integrada ao eu perceptivo” (UAC, p. 58).

Há assim uma certa atividade orientada (SC, p. 41). Ou seja, agimos em direção a uma mobilidade privilegiada. Isto certamente nega que o comportamento seja um processo linear do organismo ao meio: há sempre uma escolha (no caso do sujeito normal).

No fundo, isto nos diz de uma estruturação global na ação do corpo, que por sua vez é aberto a um sistema de ação possível (PhP, p. 287), assim como escolhe um modo privilegiado de ação. Buytendijk (1965, p. 56) é decisivo neste caso: “o homem não tem um mundo ambiente, ele tem um mundo. Em face deste mundo ele escolhe um ponto de vista”.

O interessante é que esta idéia vai de encontro com os gestaltistas: não se trata de agir seguindo o menor esforço possível (KOFFKA, 1955, pp. 107-108). O comportamento privilegiado não é a lei do "menor esforço”, como se poderia pensar. Merleau-Ponty é bem astuto nesta crítica: "não é porque o comportamento é mais simples que ele é privilegiado, é, ao contrário, porque ele é privilegiado que ele é mais simples” (SC, p. 159).

Sendo assim, as ações do organismo seguem aquilo que lhe é mais simples, segundo o que para ele é privilegiado, modificando a tão difundida idéia de good Gestalt como as preferências definidas na atividade do organismo ${ }^{13}$. Isto porque o equilíbrio vital não depende

\footnotetext{
${ }^{13} \mathrm{O}$ que, de algum modo, mostra como Merleau-Ponty busca, na verdade, re-examinar a noção de Gestalt e não negá-la: "as leis de Wertheimer levam à formação de estruturas às condições objetivas nas quais se apresentam os estímulos — lei da proximidade, lei da semelhança qualitativa —, ou à estabilidade da 'boa forma' considerada como uma propriedade que lhe é inerente. Se ocorre que, com efeito, a nossa percepção obedeça a estas leis, não é porque ela seja assimilável a uma estrutura física. É que o funcionamento do sistema nervoso, em despeito das interações perpétuas das quais ele é a sede, é organizado de tal modo que as leis de Wertheimer
} 
da situação local, como prega os gestaltistas (da situação do próprio campo perceptivo), mas de uma relação mais "estreita” entre a situação e a atividade total do organismo. Goldstein (1939, p. 360) é quem nos aponta esta idéia: “o comportamento privilegiado, realizado num campo, depende das condições de todo o organismo numa dada situação”.

Isto nos deixa claro que o problema do modo de relação do sujeito com seu ao redor está não só orientado versus às ações possíveis, como segue uma certa orientação privilegiada dependente da situação de todo o organismo: nós escolhemos modos privilegiados de ação diante de uma situação dada.

Uma conseqüência disto é a constatação de que o espaço ao nosso redor não é simplesmente um espaço físico, mas um espaço investido por nosso corpo: mesmo uma criança que não tenha ainda consciência de seu corpo se move em direção às coisas (Sorb, p. 32). Há assim um espaço vivido, investido por mim: não posso dizer que estou no espaço como digo que esta tela está na minha frente. Eu habito o espaço (PhP, p. 162) e nele me oriento segundo minhas ações possíveis e privilegiadas.

Isto nos indica um certo poder do corpo em suas ações possíveis diante do mundo: “meu corpo tem poder sobre o mundo quando minha percepção me oferece um espetáculo tão variado e tão claramente articulado quanto possível, e quando minhas intensões motoras, desdobrando-se, recebem do mundo as respostas que esperam” (PhP, pp. 289-290). Veremos isto melhor no próximo capítulo.

Seja como for, isto nos leva claramente a um outro problema: se estou diante de uma situação da qual posso escolher minha ação, então Sartre estaria correto em dizer que sou totalmente livre, já que seria eu quem instauraria o sentido de minha ação diante de uma facticidade?

possam valer — é, em outros termos, porque ele teve a sorte de reencontrar nelas constantes admitidas pela atividade total do organismo. São os próprios princípios da Gestalttheorie que nós invocamos contra ela” (SC, p. 163). 


\section{7) As motivações}

Sabemos que em Sartre (2006, p. 299) o conceito de situação deve se relacionar necessariamente a dois outros conceitos: à facticidade e à liberdade. Ou seja, estar em situação significa estar num contexto histórico, num contexto de exercício da liberdade. Este exercício seria a capacidade do indivíduo de se por adiante de si, numa projeção de si mesmo. Já a facticidade seria o elemento que constituiria a situação: aquilo que me precede e que já está constituído. Como vemos, trata-se de relacionar uma certa projeção de si, numa dada situação constituída, a partir de um contexto em que posso exercer minha liberdade (SARTRE, 2006, pp. 477-601). Neste caso, o indivíduo teria sempre a capacidade de atribuir significação à situação factual para exercer sua existência (sua liberdade). Não é difícil vermos que o sujeito sartreano é um sujeito que atribui sentidos ao mundo, às situações factuais, se projetando ao mundo dependendo destas atribuições. É exatamente esta relação fundamental de atribuição o exercício de liberdade para Sartre — esta capacidade de projeção que nos leva a transcender a facticidade.

Aos olhos de Merleau-Ponty, Sartre torna a liberdade impossível: se toda ação é uma ação livre, então a própria noção de escolha parece se suprimir, já que a escolha deveria se fazer diante de um campo de possíveis (PhP, p. 512). Ora, se eu sou totalmente livre para dar sentido à situação, com efeito, não há nenhuma situação de fato — só posso ter uma ação livre se posso dicernir uma ação possível diante de um “fundo/horizonte” possível de ação. Nestes termos, só poderíamos escolher se supormos diante de nós “escolhas” numa situação já constituída e que podemos (a partir de) constituir algo novo (uma situação possível). Não sou totalmente livre (não posso transformar totalmente meu ser no mundo) porque pressuponho minha situação no momento, tanto corporal quanto histórica, e seria a partir deste fato que se poderia esboçar algo possível (não uma liberdade absoluta). 
Isto significa que, diante de uma situação conhecida, segundo Merleau-Ponty, é provável que agirei de um modo habitual (PhP, p. 505). Whiteside (1988, p. 70) é suscinto aqui: "hábitos, tedências, características persistentes de personalidade e modos preferenciais de conduta são a base de uma concepção fenomenológica de probabilidade”. Haveria assim um jogo fundamental entre constituinte/constituído e certamente um privilégio da ação habitual ou preferencial, como veremos no próximo capítulo com detalhe, pois o corpo tende a agir de modo privilegiado numa mesma situação. Já para Sartre, não pode haver este provável: ajo deste modo porque sou livre para agir assim, porque atribuo a esta facticidade uma significação e me projeto diante dela ${ }^{14}$. Por aí, perde-se de vista uma condição concreta a Merleau-Ponty no exercício da liberdade: um provável em toda escolha.

Neste sentido, a grande diferença com as análises de Merleau-Ponty está em relação à atribuição de sentido. Para o filósofo, posso agir de um modo diferente do habitual, certamente, mas isto se deve a algum tipo de motivação: a situação me incitaria a agir diferentemente do meu modo habitual, o que equivale a dizer que o mundo suscita um sentido. Há uma passagem lapidar de Buytendijk (1965, p. 93) que nos explicita este problema: “ver alguma coisa não é, em primeiro lugar, perceber objetivamente um objeto, é, antes de tudo, ver o que suscita em nós uma sensação de ação possível.”. Nada mais claro.

Para Merleau-Ponty, há um conceito mais certeiro para designar este “suscitar”. Tratase uma vez mais de retomar a fenomenologia husserliana: o mundo me motiva a agir. Eis “(...)

\footnotetext{
14 Podemos nos apoiar nesta passagem de Safatle: “como a posição do cogito pré-reflexivo pela psicanálise existencial de Sartre apaga o locus do inconsciente freudiano, o desejo poderá ser assumido pelo sujeito no final do processo analítico sob a forma de um projeto determinado por uma escolha original do para-si. Pois trata-se de 'trazer à luz, sob uma forma rigorosamente objetiva, a escolha subjetiva através da qual cada pessoa se faz pessoa, ou seja, se anuncia a si mesma o que ela é'. Em Sartre, a falta de ser do desejo indica uma liberdade absoluta, já que o desejo como falta de ser aponta para uma ausência de determinismo nas relações de objeto que permite o advento da livre escolha. Este projeto original de ser é desejo de ser através do qual o ser se exprime. Princípio de expressividade tributário de um horizonte de transparência absoluta da consciência e de um certo horizonte regulador de transparência absoluta do social enquanto campo no qual a conduta se engaja. Daí a crítica lacaniana à ‘ilusão de autonomia' e à ‘auto-suficiência da consciência’ na filosofia sartreana” (SAFATLE in GONÇALVES et al., 2006, p. 143).
} 
um destes conceitos ‘fluentes’ que é preciso criar se se quer retornar aos fenômenos”, segundo Merleau-Ponty (PhP, p. 61).

Motivation é um conceito particularmente interessante porque indica uma relação não causal no comportamento, quer dizer, algo que pode suscitar meu comportamento sem que com isso haja somente uma relação física, mas também uma significação. Por exemplo: pego este martelo na minha frente devido à sua utilidade ou beleza, ou segundo qualquer outro sentido que ele me suscite (HUSSERL, 1952, pp. 372-377) ${ }^{15}$.

O curioso é que este conceito tem também suas raízes na Gestalttheorie:

não há uma razão, mas um motivo. É justamente a Gestalttheorie que nos faz tomar consciência das tensões que atravessam como linhas de força o campo visual e o sistema corpo próprio-mundo e que os animam de uma vida surda e mágica, impondo, aqui e ali, torções, contradições e dilatações (PhP, p. 60; KOFFKA, 1928, p. 320).

Seja como for, a motivação é um conceito fundamental no arcabouço conceitual da fenomenologia de Merleau-Ponty. É através dela que é possível explicar como não somos totalmente determinados pelo mundo e como não somos totalmente livres. É a motivação que me traz uma certa conduta possível. É ela que torna possível uma ação possível: como na causa, “o motivo tem um antecedente”, mas, diferentemente de um determinismo, eu “ajo somente por seu sentido” (PhP, p. 299).

O exemplo mais claro disto é de Goethe. Sua tese é a de que o sujeito tem um efeito sensível-moral da cor (GOETHE, 1996, pp. 128-157). Merleau-Ponty acompanha esta idéia: “(...) cada cor desempenha um modo de atmosfera moral” (C, p. 29). Por exemplo: o roxo pode exagerar minha reação sem que eu perceba (PhP, p. 243). O azul é o que solicita de mim um certo modo de olhar (PhP, p. 243). É porque a cor é assumida com uma significação motora, como um certo modo de agir (PhP, pp. 2243-245). O próprio Goldstein (1938, p. 266)

\footnotetext{
${ }^{15}$ Neste apêndice, Husserl insiste que nós devemos distinguir três figuras do eu: o eu empírico (psicológico), o eu espiritual (pessoal) e o eu puro. É na descrição do eu espiritual que encontramos a idéia de motivação (HUSSERL, 1952, p. 375).
} 
parece se admirar ao confirmar clinicamente esta tese de Goethe: “como está próxima a relação das cores a certas atitudes comportamentais totais (...)!”

Do mesmo modo, é isto que faz com que o mel, esta coisa viscosa e açucarada, me leve a “(...) uma certa conduta que ele nos sugere ou nos impõe, uma certa maneira que ele tem de nos seduzir, de atrair, de fascinar o sujeito livre que se encontra confrontado com ele. O mel é um certo comportamento do mundo para com meu corpo e eu” (C, p. 27).

Lembremos também como Merleau-Ponty se apoiava na gestalttheorie (KOFFKA, 1928, pp. 301-320) ao buscar na fisionomia humana uma forma privilegiada das significações humanas para a criança. É porque a fisionomia expressa um sentido, motiva uma conduta possível. A criança percebe o sorriso. Ela retribui um sorriso. Ela é motivada a isto. Do mesmo modo, quando percebo o rosto colérico de um amigo: sou motivado a agir diferentemente de como ajo normalmente. Ele expressa algo que posso compreender e que me leva a agir de um modo que pressuponha esta cólera.

O caso de Schneider ainda é útil aqui para esclarecermos este problema. O diagnóstico em Schneider é que ele não percebe como um sujeito normal: ele precisa utilizar da linguagem para “penetrar” nas coisas. Isto é, Schneider perde uma familiaridade com o mundo, já que os objetos não lhe "falam” (não lhe motivam a algo) como "falam” ao sujeito normal:

é esta familiaridade, esta comunicação com o objeto que está aqui interrompida. No normal, o objeto é 'falante' e significativo, os arranjos de cores imediatamente ‘querem dizer' algo, tanto que no doente a significação deve ser trazida de alhures por um verdadeiro ato de interpretação (PhP, p. 153).

Em poucas palavras, o mundo parece não lhe sugerir uma significação, ou parece não ter uma “fisionomia” (PhP, p. 153). Schneider estaria então preso a um mundo concreto, a um mundo afetivamente neutro (PhP, p. 183). É por isso que a sexualidade em Schneider também teria uma outra significação, pois “é a estrutura mesma da percepção ou da experiência erótica que é alterada em Schn. [Schneider]” (PhP, p. 182). Quer dizer, o mundo é neutro para 
Schneider porque as coisas não lhe despertam, não lhe motivam, uma "fisionomia sexual" diferentemente do mundo do homem normal que é

(...) habitado por uma percepção mais secreta: o corpo visível é subtendido por um esquema sexual, estritamente individual, que acentua as zonas erógenas, desenha uma fisionomia sexual e apela ao gesto do corpo masculino, ele mesmo integrado a esta totalidade afetiva (PhP, p. 182).

O argumento de Merleau-Ponty é então este: as coisas não estão diante de nós como objetos neutros. Elas nos simbolizam uma certa atitude, nos leva a uma certa reação. Não se trata de uma relação distante, pois cada uma das coisas no mundo fala ao nosso corpo e à nossa vida:

as coisas não estão diante de nós como simples objetos neutros que nós contemplamos; cada uma delas simboliza para nós uma certa conduta, nós as chamamos, provocam em nós reações favoráveis e desfavoráveis, e é por isto que o gosto do homem, seu carácter, a atitude que ele toma em vista ao mundo e do ser exterior, se lêem nos objetos que ele escolhe se rodear, na cor que ele prefere, nos lugares de passeio que ele escolhe (C, p. 28).

Seja assim, o que Merleau-Ponty nos aponta é um modo relacional do sujeito com o mundo que supõe, claramente, dois problemas complementares: as ações possíveis diante de uma situação, mas que só são possíveis devido às motivações que o mundo me suscita.

\section{8) Estar aberto ao mundo...}

Neste capítulo, pudemos entender primeiramente como era fundamental ao filósofo criticar um modo relacional partes extra partes. A crítica não era gratuita: se pudéssemos pensar nossa relação com o mundo como se pode pensar a relação de uma coisa com outra coisa, poderíamos dar aos físicos um “capítulo a mais” a seus estudos. O problema é que este modo relacional é incompatível com o modo relacional que vivenciamos. Isto, para MerleauPonty, diz tudo. É um fato: nós não presenciamos isto. 
Vimos também como o filósofo pode encontrar nas linhas de Heidegger um caminho por se seguir: um modo relacional aberto ao mundo. Mas esta abertura ao mundo, em Merleau-Ponty, tem um estatuto muito específico: uma abertura ao reino do possível. Isto lhe possibilitava pensar uma relação ambígua: é preciso levarmos em conta tanto uma orientação corporal ao mundo quanto as motivações que o mundo nos suscita. Mas há ainda mais uma questão a se acrescentar e que será delineada no próximo capítulo: é preciso considerar também a "história sedimentada” do sujeito.

Mas por agora, reparemos como, segundo Merleau-Ponty, todo movimento do corpo próprio está ligado, de certo modo, a uma orientação corporal. Quer dizer, há uma certa orientação “motora” (Bewegungsentwurf, como diria Goldstein) (PhP, p. 128). Na verdade, o projeto do filósofo tem um objetivo claro: “projeto motor e movimento não são dois fenômenos ligados, mas como um só fenômeno com duas faces, e meus movimentos são para mim bem menos um deslocamento objetivo ao qual eu assistiria apenas suas modalidades diversas da relação global ao mundo onde meu corpo é o veículo” (TT, p. 19). O que Merleau-Ponty quer dizer com isto?

Se mesmo uma criança que ainda não tem consciência de seu corpo, que está "quase” numa ignorância de suas ações, se move em direção às coisas (Sorb, p. 32), é porque haveria uma solidariedade entre a motricidade e a sensação:

segundo as experiências de Goldstein e Rosenthal, cada cor determina uma atitude de nosso corpo, preparando para uma atividade ou inatividade motora. (...) Todo movimento é descrito sobre um fundo perceptivo, e toda sensação implica uma exploração motora ou uma atitude do corpo. (...) A psicologia da forma obriga-nos então a reconsiderar o problema da sensação e do movimento: é preciso falar do ponto de vista perceptivo e do aspecto motor da conduta, isto é, de dois aspectos de uma mesma realidade (Sorb, pp.180-181; 261).

Isto nos leva a pensar como estamos no mundo numa relação, antes de mais nada, intencional. Meu corpo se orienta ao mundo, destacando um arraigar profundo entre a consciência e a natureza. Barbaras (2005a, p. 224) nos participa: “isto testemunha uma ‘intencionalidade’, uma orientação; o mundo com o qual ele [o organismo] se relaciona não é 
uma realidade em si, mas sim uma constelação significante”. Esta tese, aliás, também se desenhava em Buytendijk (1965, p.22):

(...) o comportamento só nos é inteligível se nós compreendermos os movimentos e as posições do corpo não como contrações de músculos, que são ligados a fenômenos do sistema nervoso, mas como atos que são orientados em direção a uma situação; breve, como a expressão de uma significação vivida e de uma atividade intencional.

As relações motivadas estão presentes no nível corporal: o sensível propõe continuamente uma "solicitação". O que podemos compreender disto é bastante importante no projeto merleau-pontyano: se uma criança de colo responde a um sorriso, por exemplo, isto quer dizer que ela “compreende” de algum modo este sorriso. No primeiro capítulo pudemos mostrar como isto nos levava a pensar que o mundo é “prenhe” de sentido. Já neste capítulo, pudemos compreender como isto se deve também às motivações que a fisionomia lhe suscita. Devemos agora compreender que esta resposta pressupõe uma compreensão que não pode ser expressa pela função simbólica ou objetivante (PhP, p. 164), mas por uma intencionalidade original (PhP, pp. 160;444), como uma “fenomenalização” mais profunda que solicita uma intencionalidade motora (PhP, p. 128) ${ }^{16}$ (uma intencionalidade corporal) que está muito próximo destas palavras dos inéditos de Husserl: “a consciência não é originalmente um eu penso, mas um eu posso [ich kann]” (PhP, p. 160). Entendamos.

Merleau-Ponty nos apontava no possível o sentido próprio de debate do sujeito corporal com o mundo. Mostrava também que este sujeito se orienta ao mundo, numa abertura a este possível devido às motivações que o mundo lhe desperta. Mas o modo próprio de abertura deste ser-no-mundo é um comércio originário pré-reflexivo, o que demonstra que não se trata de uma abertura da consciência enquanto “eu penso que”. É o próprio corpo que está aberto ao mundo antes de qualquer pensamento: ele já está se comunicando com ele. Quer dizer, há uma solicitação do mundo vivido que garante a imersão da subjetividade no

\footnotetext{
${ }^{16} \mathrm{Na}$ verdade, isto parece mais próximo de Scheler (1928, p. 366), ao afirmar uma "intencionalidade motriz". De qualquer modo, é no debate com Husserl que esta problemática surge explicitamente em Merleau-Ponty.
} 
sensível: os objetos estão aí como que simbolizando uma conduta. Mas o que Merleau-Ponty destaca agora é que o corpo está orientado ao mundo segundo uma intencionalidade própria: uma intencionalidade de um Eu que está no nível corporal, o que nos levará a entender que “(...) meu corpo é meu poder geral de habitar todos os meios do mundo (...)” (PhP, p. 359).

O que isto significa? Eis nosso próximo passo. 


\section{Terceiro capítulo - A consciência enquanto “eu posso"}

\section{1) Um modo original do corpo se relacionar com o mundo: um novo estatuto do "saber"}

Sentado aqui diante desta tela, pensando em como poderia começar este capítulo, olho ao meu redor em busca de um cinzeiro. Na verdade, nem havia notado que tinha acendido este cigarro. E no propósito de me levantar em busca do cinzeiro, percebo que estou com um bom exemplo em mãos do que gostaria de debater neste capítulo: como não notei que acendi este cigarro? Quer dizer, lembro-me de estender meu braço direito em direção à mesa, de escolhêlo entre muitos e de acendê-lo com um palito que estava debaixo de um livro, mas fiz tudo isso sem pensar em fazê-lo. Não foi preciso que eu pensasse com que braço deveria estender para solicitá-lo ou com qual iria buscar aquele palito. Tudo se passou como de hábito. Como isso é possível?

Certamente não poderíamos explicar este gesto segundo uma consciência que tenha plena determinação de seus atos. A sugestão de Merleau-Ponty é que “o movimento do corpo não pode ter um papel na percepção do mundo se ele mesmo não é uma intencionalidade original, um modo de se relacionar ao objeto distinto do conhecimento” (PhP, p. 444). É este modo original do corpo se relacionar com o mundo, este movimento corporal em direção ao mundo, que poderá explicar aquele gesto, segundo o filósofo. Trata-se de pensar que “a 
consciência não é originalmente um eu penso, mas um eu posso [ich kann]” (PhP, p. 160) ${ }^{1}$. Vejamos isto mais de perto.

Merleau-Ponty quer nos mostrar como o corpo tem um papel na consciência perceptiva, não somente o papel “óbvio” de ser meu "ponto guia”, de onde vejo, mas desempenha realmente uma função na percepção sem a qual deveria a todo o momento ter que me perguntar como agir. Na verdade, o corpo passa a ter na Phénoménologie de la Perception um papel tão fundamental na relação com o mundo quanto o próprio estatuto do saber deve ser revisto. Claude Lefort (1978, P. 117) é quem nos adverte: “é a análise do corpo que, dentro da Phénoménologie de la Perception, requer um novo estatuto do saber. Tem-se que convir que há um saber do corpo e mesmo, espalhado nele, um saber dos órgãos, do olho ou da mão, deve-se renunciar ao modelo da consciência como transparência a si (...)”.

Tudo indica que Merleau-Ponty encontra na orientação corporal um certo tipo de “saber” do corpo, como se meu corpo se movesse em direção às coisas devido a um saber vivido ou um saber corporal que seguiria uma lógica vivida (PhP, p. 61). Esta passagem não deixa dúvidas: meu corpo é “(...) o instrumento geral de minha 'compreensão”” (PhP, p. 272). Um exemplo:

meu olhar 'sabe' o que significa aquilo que significa tal mancha de luz em tal contexto, ele compreende a lógica da iluminação. Mas geralmente existe uma lógica do mundo que meu corpo inteiro esposa e pela qual coisas intersensoriais se tornam possíveis para nós. Meu corpo, enquanto é capaz de sinergia, sabe o que significa para o conjunto de minha experiência tal cor (...), de um só golpe ele apreende sua incidência na apresentação e o sentido do objeto (PhP, p. 377).

\footnotetext{
${ }^{1}$ Vale a transcrição desta passagem de Geraets que elucida este problema do "eu posso" em Husserl (mesmo que não seja exatamente assim que Merleau-Ponty siga esta problemática, como veremos): "quando nós vemos, compreendemos etc., nossos órgãos da percepção operam de comum acordo com a motricidade própria que lhes correspondem. Esta unidade de operação engloba todas as percepções e todos os movimentos do corpo próprio. A sensibilidade, a operação própria de meu corpo e dos órgãos do corpo têm um papel essencial em toda experiência da realidade corporal. Para a consciência, as aparições sensíveis só são verdadeiramente aparições de realidades corporais na sua unidade com a própria corporeidade que opera de modo kinestésico e com o ego que é aqui operante numa atividade e num hábito particular. Todo este 'operar' permanece muitas vezes imperceptível, pelo fato de nós nos voltarmos para os objetos que nós tematizamos. Mas nós somos capazes de refletir sobre nossa atividade, de tematizá-la e de objetivá-la - somente fazendo assim nós estamos ainda agindo, operando, num agir que, por seu lado, permanece não-tematizado. Em suma, o ego operante não é somente corpo, mas enquanto corpo vivo ele é já ego e permanece operante, mesmo na reflexão sobre sua própria operação” (GERAETS, 1971, p. 174).
} 
Isto significa, para o filósofo, que não se pode “(...) esquecer aqui que é através do meu corpo que eu vejo o mundo, a experiência tátil se faz ‘antes’ do eu, e não é centrada num eu. Não sou eu quem toca, é o meu corpo (...)” (PhP, p. 365). Isto é fundamental a meu ver: haveria assim uma "lógica” corporal que agiria segundo uma intencionalidade originária ou mesmo uma lógica “cega” à lógica objetiva (Sorb, p. 80). Esta lógica seria solidária a um certo tipo de poder corporal.

Certamente, talvez este seja o conceito mais enigmático que podemos apontar nas suas primeiras obras. O que dizer de um certo tipo de "poder do corpo”? Como é possível dizer de um “saber corporal”? Tentarei neste capítulo dar alguns traços de como poderíamos pensar estes conceitos. É disso que irei tratar neste capítulo e das conseqüências que isso nos leva a pensar.

\section{2) A imitação infantil}

O objetivo de Merleau-Ponty é então de demonstrar como o movimento corporal assume um papel intencional na relação do corpo com o mundo. Um caminho para acompanharmos isto é a descrição da imitação infantil, já que aí vemos claramente um papel do corpo na imitação.

Segundo o filósofo, diferentemente do que professava a psicologia clássica, imitar não poderia ser compreendido como um ato derivado do "eu penso que”, ou seja, não poderia ser pensado como um ato "representado" ou "projetado”, como se tal fosse um caso particular do “pensamento objetivado”. O fato da criança não imitar “gesto por gesto” o comportamento do outro nos demonstra isto: ela busca imitar o sentido geral do gesto. É por isso que Merleau- 
Ponty nos propõe pensar de um outro modo: pensemos este ato como uma operação existencial (PhP, p. 165). O que significa isto?

Para o filósofo, o ato de imitar é uma operação corporal: “o mimetismo ou a mímica é o poder de tomar como minhas as condutas ou as expressões da fisionomia, e este poder me é dado com a potência que eu tenho sobre meu corpo próprio” (RAE, p. 215, grifo meu). Como vemos, há por um lado uma certa aquisição da conduta do outro, o que nos leva a questionar como a criança aprende; e há, por outro lado, um certo tipo de poder corporal.

Antes de mais nada, é importante ressaltar que Merleau-Ponty divide a psicologia infantil em “duas grandes tendências”:

de um lado as pesquisas que tentam compreender os melhores resultados obtidos pela criança ligandoos ao desenvolvimento da inteligência; do outro, as pesquisas contemporâneas que encontram uma ligação entre os progressos intelectuais da criança e suas relações com seu corpo e com os outros: os progressos são correlativos (Sorb, p. 525).

No primeiro caso, trata-se das análises de Piaget. Quer dizer, para Piaget, imitar, por exemplo, significa um começo de assimilação generalizadora, antecipadora e propulsora da função representativa (Sorb, pp. 183-185) (o corpo aí seria apenas um objeto entre outros, representativo).

No segundo caso, trata-se das análises de Wallon e Guillaume:

antes de imitar o outro, a criança imita os atos do outro [Guillaume]. Essa primeira imitação supõe que a criança aprenda globalmente o corpo do outro como portador de condutas estruturadas e que experimente seu próprio corpo como um poder permanente e global de realizar gestos dotados de um certo sentido. Isto quer dizer que a imitação supõe a apreensão de um comportamento no outro e, do lado do eu, um sujeito não contemplativo, mas motor; um 'eu posso' (Husserl) (Sorb, pp. 34-35, grifo meu).

Isto significa, primeiramente, que a criança não pretende imitar ponto por ponto o gesto do outro, mas pretende atingir um resultado global do comportamento do outro. Isto é, a criança não busca o detalhe do gesto percebido, mas o gesto como um todo (como uma Gestalt). Segundo, a criança experimenta em seu corpo um "poder” de realizar gestos dotados de sentido. Quer dizer, Merleau-Ponty parece afirmar uma certa produtividade corporal: um 
certo poder do movimento corporal se polarizar numa intenção específica, criando uma “estrutura” de comportamento — um poder oculto de criar diferentes estruturas de nossa experiência (PhP, p. 87).

Para tentarmos entender isto, lembremos que este poder de criação de estruturas comportamentais é o caminho de crítica ao behaviorismo em La Structure du Comportement. Percebamos: como age um animal frente a uma nova situação? Seria apenas mais um "teste" de acerto e erro ou o comportamento seria uma nova atitude diante da situação?

Se a teoria do reflexo condicionado supõe que o aprendizado é uma repetição de um ato satisfatório já apreendido, não poderíamos entender como em cada situação o organismo poderia reagir sem colocar em evidência um caráter “abstrato” da própria reação (SC, p. 107). Ou seja, a uma dada situação, mesmo que o problema seja de certo modo "já conhecido", sempre se supõe uma possibilidade de uma nova forma de ação, ou uma nova atitude.

Note-se que, mesmo Watson impondo uma interpretação a favor do “comportamento”, encerra o indivíduo numa rede de condutas do sistema nervoso sem que haja, por este motivo, um sentido na ação, como supunha inicialmente (Sorb, p. 429). Explica-se assim a ação em termos de aquisição, como num controle do comportamento, já que todo comportamento seria aprendido, condicionalmente, segundo leis, principalmente dos atos freqüentes e recentes. Isto é, segundo a repetição de uma ação, apreenderíamos a reação adequada, através de tentativas e erros, assim como poderíamos repetir uma ação bem-sucedida recente.

Entretanto, à fórmula behaviorista E-R, os gestaltistas retificam: “a fórmula psicológica correta é a seguinte: modelo de estímulo - organização - reação aos produtos da organização” (KÖHLER, 1947, p. 97). Quer dizer, o aprendizado não segue a rigidez de um condicionamento, porque há sempre uma organização perceptiva que torna possíveis reações diversas frente a uma situação: há sempre algo que me motiva a agir de tal modo e não algo que me determina a agir de um modo específico. 
O essencial não é, como vemos, a repetição, mas o sentido da reação (seja qual for o meio necessário para tal). De certo modo, isto pressupõe um certo tipo de intencionalidade: interessa mais o modo de como se age e não a contigüidade entre uma situação e a reação. É nesta variação possível de reação que Merleau-Ponty encontra uma produtividade do corpo de reagir intencionalmente frente a uma situação: “aprender não é jamais ser capaz de repetir um mesmo gesto, mas de fornecer à situação uma resposta adaptada por diferentes meios” (SC, p. 106).

É esta “capacidade” de se por numa situação possível que se está colocando também na imitação infantil. A imitação seria algo aderente à existência corporal enquanto tal: um poder de expressar um comportamento do outro, e não de repetir a conduta do outro. Não se trata de um poder de "síntese intelectual" do comportamento ou um poder de associar os gestos de outro com os seus, mas um poder de realizar uma conduta que reconheço possuir em mim. É neste sentido que Merleau-Ponty podia afirmar uma certa intencionalidade corporal: a criança tem um “poder” corporal de imitar o outro ao apreender o corpo do outro globalmente, reconhecendo-o como portador de condutas estruturadas e reconhecendo a si como portadora deste sentido.

Certamente, este “poder corporal” ainda se desenha confusamente. Tentemos esclarecê-lo de um outro modo.

\section{3) O hábito corporal}

Na Phénoménologie de la Perception, este “poder corporal” aparece em vários momentos. Um exemplo privilegiado deste caso é o hábito corporal. Assim como a imitação infantil, o hábito seria uma aquisição de uma “esfera primordial” de significações na própria 
motricidade do corpo. Na verdade, o hábito indica uma esfera "sedimentada" das nossas condutas sempre presente em nossas ações, sem com isso determiná-la, pois há sempre uma abertura possível nas ações. O hábito teria assim a função de resposta imediata do corpo, sem que seja preciso nos perguntar como agir diante da situação.

Trata-se então de uma “esfera constituída”, “já sabida”, que pode ser retomada em toda situação parecida. Lembremos do exemplo do cigarro, que eu dizia nas primeiras linhas deste capítulo. Meu corpo é capaz de agir sem que eu me pergunte como agir: estendo meu braço direito em direção ao cigarro e o acendo, sem ter que me perguntar com qual braço irei realizar tais ações. Eu me “flagro” fumando. Há assim um duplo movimento: uma sedimentação e uma espontaneidade (PhP, p. 152), que se dão na própria ação, sem que eu precise me perguntar como devo agir.

Mas o hábito nos mostra também algo fundamental a Merleau-Ponty: uma atmosfera de probabilidade. Quer dizer, se disponho de um saber frente a situações conhecidas, ao mesmo tempo, eu posso agir diferentemente frente à mesma situação. Entretanto, é provável que eu aja de um modo habitual, sem com isso excluir que "eu posso" agir de um outro modo. Há sempre um "poder de agir” que transborda qualquer determinismo, mas que não ignora a nossa história, nossos modos privilegiados de agir, pois é sempre a partir desta história sedimentada que posso agir ou pensar (PhP, p. 453).

Isto significa que há uma situação de abertura na ação que não é simplesmente determinada por sua história, mas que a motiva largamente. Noutras palavras, há sempre um modo privilegiado de resolução de um problema que se baseia numa "história sedimentada" que eu não posso simplesmente ignorar (PhP, p. 505). É importante ressaltarmos como esta idéia vai diretamente contra Sartre (como apontávamos acima): não se trata de dizer que somos ou não livres. Para Merleau-Ponty, há o provável: é provável que eu aja assim, pois existe um "eu habitual”. 
No linguajar merleau-pontyano, poderíamos dizer que há um estilo de ser (PhP, p. 506) que motivaria minhas ações e que, ao mesmo tempo, não as impediria de serem tomadas de um novo modo. Por isso mesmo, “a aquisição do hábito como remanejamento e renovamento do esquema corporal oferece grandes dificuldades às filosofias clássicas, sempre levadas a conceber a síntese como uma síntese intelectual” (PhP, p. 166).

Sendo assim, Merleau-Ponty tem exatamente em mente aquele poder corporal de responder ao meio, seja de forma habitual, seja numa nova forma ( $\mathrm{PhP}, \mathrm{p} .166)$. Tem em mente compreender um problema pré-objetivo, pois o corpo compreenderia a situação sem que eu precisasse tomar consciência explícita dela: não precisamos representar um espaço para "sabermos” que por ali passamos, assim como não precisamos representar a largura do carro para podermos passar num beco. Isto significa, aos seus olhos, que eu habito o espaço (PhP, p. 289), como se houvesse um pacto entre meu corpo e o mundo, ou um meio geral no qual meu corpo e o mundo coexistiriam (PhP, p. 290).

É certo que o corpo habita o espaço diferentemente de como uma coisa está num espaço (TT, p. 39). Do mesmo modo, é certo também que há um modo muito original do corpo habitar este mundo. O que atesta isto, por exemplo, é nossa orientação do corpo, que é solidária a um sistema de ação possível (PhP, p. 289).

De qualquer forma, se sou capaz de me abaixar diante de um galho sem ter que medir o quanto devo abaixar para não esbarrar neste obstáculo, é porque há, por exemplo, um saber de potência volumosa (PhP, p. 167) em que

os lugares do espaço não se definem como posições objetivas em relação à posição objetiva de nosso corpo, mas eles se inscrevem em torno de nós o alcance variável de nossos objetivos ou de nossos gestos. Se habituar a um chapéu, a um automóvel ou a uma bengala é se instalar neles, ou inversamente, os fazer participar do volume do corpo próprio. O hábito exprime o poder que nós temos de dilatar nosso ser no mundo ou de mudar de existência anexando a nós novos instrumentos. (PhP, p. 168).

O que isto quer dizer? 
Primeiro, que a imitação e o hábito são condutas expressas do corpo. Ou seja, são condutas que posso realizar sem me perguntar como devo realizar. Segundo, que há uma compreensão corporal: o corpo compreende os gestos do outro, assim como compreende como agir em dadas situações, como é o caso das minhas mãos digitando estas teclas: se alguém me perguntar em qual posição está a letra “d”, eu teria dificuldade em indicá-la, mas posso escrever o substantivo “dado" sem que meus dedos vacilem em teclar as letras correspondentes que compõem esta palavra. É como se houvesse uma fisionomia típica ou familiar (PhP, p. 168) nestas teclas.

Eis então para onde esta análise nos aponta: “(...) o fenômeno do hábito nos convida a remanejar nossa noção de ‘compreensão’ e nossa noção de corpo. Compreender é experimentar o acordo entre o que nós visamos e o que é dado, entre a intenção e a efetuação — e o corpo é nosso ancoradouro no mundo” (PhP, p. 169).

Esta é uma idéia profunda, a meu ver, e atesta aquela advertência de Lefort: $o$ estatuto do saber está aqui modificado. É o corpo que compreende o mundo, a seu modo. É profunda também porque nos permite compreender um modo original do corpo se relacionar com o mundo: o corpo esboça um papel na relação com o mundo diferentemente da relação do conhecimento objetivo. Ele esboça uma intencionalidade própria: um poder de agir que está na origem da consciência enquanto “eu posso”, contando com um saber habitual.

\section{4) $O$ corpo expressivo}

Poderíamos concluir, a grosso modo, o estudo do hábito corporal segundo estas palavras: é através de algo fundado que algo fundante pode aparecer (PhP, p. 451) - é a 
partir de uma esfera sedimentada do corpo que podemos agir de um modo provável ${ }^{2}$. Quer dizer, há sempre uma história sedimentada a partir da qual eu posso agir (PhP, p. 453). O mesmo poderíamos dizer do pensamento: há sempre um “mundo pensado”, uma “sedimentação” de nossas operações mentais, “que nos permite contar com nossos conceitos e com nossos julgamentos adquiridos, assim como com as coisas que estão lá e se dão globalmente, sem que tenhamos necessidade a cada momento de refazer a síntese” (PhP, p. 151). Esta mesma lógica é o que acompanharemos na idéia do ato expressivo: só é possível um novo modo de expressão a partir de uma expressão já fundada.

A fala, igualmente como o hábito, nos apontaria para algo sedimentado em nós: uma fala instituída, já falada, secundária (PhP, p. 14). Entretanto, isto não exclui uma fala originária. Ora, o escritor pode criar um novo estilo, um novo modo de se expressar um sentido, pois "o escritor não se contenta em usar signos da língua segundo seu valor gramatical, mas faz o conjunto da sintaxe um uso tal, que uma significação inédita apareça ao ouvinte” (Sorb, p. 560). Podemos aqui dizer igualmente num estilo de ser que posso reconhecer ao ler uma obra (exatamente pela fala ser a única sedimentação intersubjetiva (PhP, p. 221)). Posso reconhecer igualmente modos distintos de se expressar e, por isso mesmo, a possibilidade de se criar modos de expressar. Esta criação é justamente o que Merleau-Ponty nos diz da fala autêntica, que sempre nos mostraria um novo sentido da fala, assim como sempre ajo de um novo modo diante de uma nova situação possível (PhP, p. 226). Haveria assim uma fala falada e uma fala falante: por um lado, uma fala instituída,

\footnotetext{
${ }^{2}$ Esta problemática já aparecia, de certo modo, em Husserl, como nos descreve Geraets: “a história compreendida como o movimento vivo do acompanhamento e do entrelaçamento da formação originária do sentido e da sedimentação do sentido é o horizonte universal de interrogação [de Husserl]. Esta interrogação toma necessariamente seu ponto de partida no nosso presente, como tempo atualmente vivido" (GERAETS, 1971, p. 139).
} 
sedimentada, adquirida; por outro, uma intenção significativa em estado nascente, um excesso de nossa existência sobre o ser natural (PhP, p. 229) ${ }^{3}$.

Mas na verdade, o ato da expressão para Merleau-Ponty tem como tema o corpo enquanto corpo falante ${ }^{4}$. Quer dizer, tem por tema descrever o poder do corpo de expressar, seja falando, seja por gestos, seja até reconhecendo no outro uma fisionomia de cólera, por exemplo. Por isso, a imitação infantil já era um ato expressivo: um poder do corpo de tomar como seu o sentido do comportamento do outro. O mesmo no hábito corporal: o poder do corpo de agir, de expressar uma conduta constituída numa situação que o corpo compreende. O jogo entre fala falada e fala falante tem a mesma função: diz de um poder corporal de criar novos meios de expressão a partir de um mundo lingüístico já dado: a língua portuguesa, por exemplo. Isto não significa que a multiplicidade de línguas comprova uma multiplicidade de convenções arbitrárias para exprimir um mesmo sentido, mas "várias modos, para o corpo humano, de celebrar o mundo e finalmente de vivê-lo” (PhP, p. 218).

Devemos, então, pensar a fala assim como pensamos um gesto: como “modulação do corpo” (PhP,p. 461), “a fala é um verdadeiro gesto e ela contém seu sentido como o gesto contém o seu” (PhP, p. 214). Ela é uma operação expressiva que desenha ela mesma um sentido. Mas exatamente por ser esta “operação” do corpo, ela é um certo poder motor (PhP, p. 462). Ou ainda: a fala é a presença motora do corpo (PhP, p. 461).

\footnotetext{
${ }^{3}$ Poderíamos certamente questionar Merleau-Ponty ao perguntarmos de onde surge este poder de abertura, este poder indefinido de significação (PhP, p. 226.) ou irracional (PhP, p. 221) de criar sentidos. Ele nos indica uma resposta: há uma natureza enigmática do corpo próprio: o corpo secreta nele um sentido que não vem de lugar nenhum, mas que emana dele para todas as direções (PhP, p. 230). Certamente isto pode parecer estranho: um poder que não vem de lugar algum parece ser um poder que não vem de nada, mas que está excedente, que nos atravessa e está na origem de toda experiência criadora. Isto não parece ter uma solução satisfatória na Phénoménologie... Mas não podemos aqui prolongar esta questão. Sugiro a leitura do texto de Moura (2001, pp. 295-335), onde esta questão é colocada de modo claro. Trata-se de uma articulação desta "produtividade" que parece não provir de nada com o não-ser sartreano, o que levava Merleau-Ponty a um impasse, segundo Moura (2001, p. 314): “como unir uma consciência compreendida como nada a um corpo próprio que é ser?”.

${ }^{4}$ A advertência de Moutinho (2006, p. 147) em seu trabalho sobre a Phénoménologie de la Perception também vale aqui: "se o leitor presumir que o capítulo sobre a fala seja o modelo da fenomenologia merleau-pontyana da linguagem, certamente terá dificuldade em compreeder por que este capítulo figura na primeira parte da Fenomenologia..., que tem por tema 'O corpo'. Contra esse presumível mal-estar, vale observar, já de saída, que o tema aqui é menos a linguagm do que o corpo falante, o corpo capaz de um gesto que se deixa investir de um 'sentido figurado' - não se trata, ainda, da linguagem como acesso à verdade, mas, sim, de desvelar uma nova face do sujeito de percepção, já que ele é, também, um sujeito falante”.
} 
A fala se revela assim como uma operação expressiva: uma "região original” de significação (PhP, p. 203). Assim como as coisas dizem algo para mim, meu corpo parece dizer algo para os outros... Quer dizer, toda fala pressupõe um sentido imanente a ela (PhP, p. 214), do mesmo modo que o mundo tem um sentido imanente que me motiva a agir de um modo possível. Isto nos indica que o corpo é um irradiador de sentidos vivos, mas também um “centro” de ação do qual temos consciência, sem que com isso digamos de uma distinção entre este corpo expressivo e sua expressão: o corpo fala. Mas também compreende (TT, p. 28): “ele [o corpo] é nossa expressão no mundo, a figura visível de nossas intenções” (PhP, p. 39).

De qualquer modo, há algo peculiar na fala: devemos entender que quem fala não está traduzindo um pensamento já feito assim como quem ouve não traduz o pensamento da fala. É famosa a passagem merleau-pontyana: “o orador não pensa antes de falar, nem mesmo durante a fala; sua fala é seu pensamento” (PhP, p. 209). Isto também não quer dizer que represento minha fala antes de pronunciá-la (assim como se diz que não represento o espaço do meu quarto para me orientar nele). Do mesmo modo que os gestos devem ser compreendidos em suas significações existenciais, para o filósofo, o mesmo devemos entender da fala, porque ela é um certo gesto corporal (PhP, p.214) que participa do meu poder expressivo (PhP, p. 213), que me abre a um novo campo de ação, a uma nova dimensão da existência (assim como posso agir diferentemente diante de uma ação nova).

Entretanto, mesmo que possamos dizer que a palavra é um certo uso do meu aparelho de fonação, uma certa modulação do meu corpo, um certo estilo de conduta que meu corpo compreende, ou ainda que meu corpo é um corpo com poder de expressar, de criar comportamento (PhP, p, 461), ainda assim temos que entender que a fala porta um sentido e veicula sua significação, assim como gesto corporal, pois “o corpo é eminentemente um espaço expressivo” (PhP, p. 171). Ora, é neste campo de ação, nesta região que se especifica a 
conduta humana (possível), que se deixa em aberto um poder de expressar e de compreender o sentido dos gestos de outrem. Eu reconheço, na fala, um sentido que me é acessível, pois reconheço, no outro, um certo estilo de fala que posso vivenciar sua significação, assim como a criança reconhece no seu corpo um poder de expressar o gesto do outro.

Haveria uma intenção significativa que poria em movimento a minha fala e a do outro, num reconhecimento “cego” (PhP, p. 216), algo que vivenciamos sem precisarmos pô-la explicitamente em pensamento (PhP, p. 214):

a comunicação ou a compreensão dos gestos se obtém pela reciprocidade de minhas intenções e dos gestos do outro, de meus gestos e das intenções legíveis na conduta do outro. Tudo se passa como se a intenção do outro habitasse meu corpo ou como se minhas intenções habitassem as suas. O gesto pelo qual eu sou a testemunha desenha pontilhado um objeto intencional. Este objeto torna-se atual e ele é plenamente compreendido quando os poderes do meu corpo se ajustam a ele e o recobre. O gesto está diante de mim como uma questão, ele me indica certos pontos sensíveis do mundo, ele me convida a juntar a ele (PhP, pp. 215-216).

Isto é muito importante porque permite ao filósofo afirmar que é pelo corpo que se expressa ao outro, que é pelo corpo que se compreende o outro, assim como é por ele que percebo o mundo (PhP, p. 216).

Seja como for, nosso objetivo era mostrar como o ato expressivo nos aponta a um poder corporal de expressar e de compreender (a partir de uma esfera sedimentada). Tratavase de destacar este ich kann que parece fundamentar toda relação do être au monde. Noutras palavras, a tomada de consciência da fala é algo tardio, pois trata-se aqui também de uma intencionalidade corporal e de um poder de significação que é de ordem corporal (PhP, p. 203) e por isso mesmo um modo próprio do corpo se relacionar com o mundo. 


\section{5) $O$ corpo libidinal}

De um modo geral, é com esta mesma idéia que Merleau-Ponty entende a sexualidade corporal: a sexualidade esboça um certo poder do corpo. Entretanto, a leitura merleaupontyana da psicanálise merece alguns esclarecimentos. Primeiro, porque ele afirma que existe uma “certa energia da pulsão de existência” (PhP, p. 95). Num outro momento, o filósofo interpreta a libido na psicanálise freudiana de um modo curioso: “(...) a libido não é um instinto, quer dizer, uma atividade orientada naturalmente a um fim determinado, ela é o poder geral que tem o sujeito psicofisiológico de aderir a diferentes meios, de se fixar por diferentes experiências, de adquirir estruturas de conduta” (PhP, p. 185, grifo meu).

Nestas duas passagens, já nos fica claro como Merleau-Ponty toma os trabalhos freudianos a partir de uma interpretação “fenomenológica”. Basta nos lembrarmos como Freud sempre destacou uma distinção entre pulsões: por um lado, as pulsões do eu; por outro, as pulsões sexuais. Não se trata de uma "pulsão geral” ou da "existência”, o que tornava possível a Freud (1953b, p. 112) se defender de qualquer "pansexualismo”:

com efeito, a psicanálise não se esquece jamais que existem tendências não sexuais, se baseando, precisamente, na definida separação existente entre pulsão sexual e pulsão do Eu, e tem afirmado, contra as objeções, que as neuroses não são produto exclusivo da sexualidade senão do conflito entre esta e o Eu.

É certo que, tão quanto, Merleau-Ponty está aqui afirmando um pansexualismo. Seu objetivo é outro: é preciso afirmar que a espacialidade corporal, assim como a sua sexualidade e sua temporalidade são problemas concêntricos (PhP, p. 469). Para o filósofo, a percepção implicaria na temporalidade, na espacialidade, na motricidade e na sexualidade, porque é todo o corpo, com toda a história do sujeito que percebe (PhP, p. 326). Ora, a sexualidade, assim como a motricidade, seria uma função integrada do ser humano por inteiro e, portanto, não poderia ser explicada por um pansexualismo (DtCz, p. 31): não se pode explicar a existência 
pela sexualidade ou vice-versa (PhP, p. 185) — a sexualidade seria apenas uma das funções do ser total.

Há assim uma coesão no todo da existência corporal, uma “estrutura concreta” (PhP, p. 469), que repousa sob o que Merleau-Ponty denomina (sob empréstimo de Fischer) de “arco intencional”:

(...) a vida da consciência — vida cognoscitiva, do desejo ou da percepção — é subtendida por um 'arco intencional' que projeta em torno de nosso passado, nosso futuro, nosso meio humano, nossa situação psíquica, nossa situação ideológica, nossa situação moral ou, antes, que faz com que estejamos situados sob todos estes aspectos. É este arco intencional que faz a unidade do sentido, entre o sentido e a inteligência, entre a sensibilidade e a motricidade (PhP, p. 158).

É por isso que, mesmo com o conselho de Bréhier de fazer do capítulo Le Corps comme Etre Sexué mais discreto (MERLEAU-PONTY, Jacques apud WHITESIDE, 1988, p. 13), Merleau-Ponty incorpora a pulsão freudiana na pretensão da descrição da "totalidade da vida”. Na verdade, não se trata exatamente de descrever esta pulsão freudiana, mas de resgatar uma unidade na descrição da relação do corpo próprio com o mundo.

Entretanto, é exatamente neste ponto que Merleau-Ponty parece se distanciar de Freud, segundo Green (1954, p. 1037): enquanto para o filósofo o problema do corpo é também um problema do corpo libidinal, para o psicanalista, o corpo é antes de tudo um corpo libidinal. Mas é verdade também que esta questão é ampliada por algumas teorias feministas. Um exemplo aparece nas análises de Butler, que encontra, nas linhas de Merleau-Ponty, uma abertura para se negar qualquer ponto de vista normativo quanto à sexualidade ${ }^{5}$.

Seja como for, é importante a Merleau-Ponty destacar que, pela própria definição de existência, a sexualidade estaria presente como uma “atmosfera” (PhP, p. 196). Está sempre

\footnotetext{
5 “Apesar de Merleau-Ponty não escrever sua teoria da sexualidade com uma explícita estrutura política, entretanto, ele oferece alguns argumentos significativos contra teorias da sexualidade naturalísticas que são úteis para qualquer esforço de explicitação política de refuta a pontos de vista restritivamente normativos da sexualidade. Argumentando que a sexualidade é co-extensiva à existência, que é como um modo de dramatização e investimento de uma situação histórica concreta, Merleau-Ponty parece oferecer às teorias feministas um ponto de vista da sexualidade livre de ideologia naturalística, restaurando componentes históricos e volitivos à experiência sexual e, conseqüentemente, abrindo caminho para muitas descrições da sexualidade e diversidade sexual” (BUTLER, 1989, p. 86).
} 
na nossa existência, “co-extensiva à vida” (PhP, p. 197), numa “osmose” (PhP, p. 197) com a sexualidade. Quer dizer, sempre somos motivados por inteiro e não saberíamos exatamente se tal ação tem um motivo sexual: "não há nada que não seja sexual; nada é a-sexual” (NC, pp. 150-151):

a existência se difunde na sexualidade, reciprocamente, a sexualidade se difunde na existência, de modo que é impossível assinalar, por uma decisão ou por um ato dado, a parte da motivação sexual e aquela das outras motivações, impossível caracterizar uma decisão ou um ato como 'sexual' ou 'não sexual' (PhP, p. 197).

Mas há ainda, certamente, ao menos mais dois temas que devemos esclarecer na interpretação merleau-pontyana da psicanálise. Primeiro, que a libido nos leva a pensar na história pessoal do indivíduo. Segundo, o fato da psicanálise nos levar a pensar que toda ação humana tem um sentido (PhP, p. 184).

No primeiro caso, devemos reconhecer que a leitura merleau-pontyana se deve muito à interpretação de Politzer ${ }^{6}$. Lembremos, por exemplo, que desde a Critique des Fondements de la Psychologie havia a pretensão de se voltar a uma psicologia concreta. Como nos participa Simanke:

o trabalho de Georges Politzer é notável em vários sentidos. Ele é, de fato, um dos primeiros a colocar a palavra de ordem do concreto na pauta do dia, com um livro que se alinhava tão bem com este novo espírito emergente nas letras francesas que não deixou de ter uma significativa progênie ao longo do tempo, sendo alvo de sucessivas retomadas, nem sempre fiéis à sua inspiração inicial, mas que não podiam evitar tê-lo como ponto de referência (SIMANKE, 2002, p. 164).

\footnotetext{
${ }^{6}$ Como nos diz Furlan, talvez não haja um capítulo em Merleau-Ponty mais politzeriano que este (sobre a sexualidade). Não por acaso, já que Politzer nos mostraria, antes de mais nada, que "a primeira pessoa representa a idéia de não se tratar o fato psicológico como independente da pessoa que o vive (...) ou, em outros termos, a idéia de que todo fato psicológico supõe o ato de um eu que o assume (...) como um movimento que transforma fatos impessoais (...) em fatos pessoais, que revelam o eu em seu centro e se definem pelo sentido que têm para ele (...), e que por isso, só podem ser explicados em primeira pessoa” (FURLAN, 1999, p. 122). Aliás, MerleauPonty ministrou um curso denominado Les Fondements de la Psychologie (em Lyon, 1945-1946) mostrando como o behaviorismo, a Gestalttheorie e a psicanálise caminhavam para uma nova noção da consciência e da significação. As notas deste curso são de Albert, com um resumo de Geraets que vale a transcrição: "Freud nos mostra que todos os fenômenos psíquicos têm um sentido, — que o sujeito aliás saberia raramente. Esta significação não é o resultado de um ato intelectual e consciente. O behaviorismo mostra que consciência não é conhecimento. A psicologia da forma faz ver que todos os atos têm uma estrutura, que não nos são sempre conscientes. Vê-se a idéia comum se desenrolar e nós podemos supor que Merleau-Ponty não tardou a tomar consciência desta convergência. Este curso nos confirma o papel importante que teve, no desenvolvimento do pensamento da psicologia de Merleau-Ponty, um livro de Politzer [Critique des Fondements de la Psychologie] que é também mencionado em La Structure du Comportement” (GERAETS, 1971, p. 8).
} 
Isto porque Politzer soube colocar a nu um certo tipo de "realismo" que atravessava várias teorias da psicologia, mas apontando saídas, vers le concret, que tanto a Gestaltthtorie, o behaviorismo e a psicanálise podiam nos fornecer. Quer dizer, estas três teorias nos levavam a pensar na “primeira pessoa”, a narrativa pessoal (récit) (POLITZER, 1968, p. 81), ou a história individual da vida dramática ${ }^{7}$ de cada homem.

Entretanto, estas novas escolas não conseguem, aos olhos de Politzer, reformular realmente os fundamentos da antiga psicologia, a não ser parcialmente: “as reformas parciais não são mais que reformas parciais” (POLITZER, 1947, p. 32). No caso da psicanálise, ela deveria ser reformulada em seus traços teóricos (ao afirmar conceitos abstratos que serviriam de guia no diagnóstico clínico), uma vez que contradiz sua ruptura com a psicologia clássica em sua prática, analisando diretamente a narração individual dos acontecimentos vividos no drama diário. $\mathrm{O}$ antítodo politzeriano seria uma retomada do drama humano ${ }^{8}$ à perspectiva da primeira pessoa. A psicanálise teria assim o mérito de resgatar a narrativa pessoal como método de análise e de acesso à subjetividade, porque “a psicanálise, por não abandonar jamais o plano do indivíduo particular, obterá conclusões concretas que alcançam os fatos em sua particularidade, e, por conseqüência, os indivíduos em sua vida concreta” (POLITZER, 1968, p. 71).

Neste caso, a "história particular" de cada um é fundamental, e é neste sentido que Merleau-Ponty resgata Politzer, para justificar sua definição de libido: “ela [a libido] é o que faz com que um homem tenha uma história” (PhP, p. 185). Ou seja, não temos como dissociar a história sexual de um homem da história de sua vida, e não temos como explicar uma pela outra, porque uma está tão arraigada à outra que somente poderíamos afirmar que um sujeito

\footnotetext{
${ }^{7}$ Que se entenda por "drama” não algo com "ressonância” romântica, mas que diz diretamente da vida do indivíduo concreto (POLITZER, 1968, p. 11).

80 que equivale à ambiguidade em Merleau-Ponty, segundo Bimbenet (2001, P. 249) : “de uma parte a outra, o movimento desta reforma imanente [a psicologia concreta proposta por Politzer] acaba por colocar em jogo um modo de ser original, irredutível ao caráter abstrato das perspectivas realistas e intelectuais - 'vida dramática' segundo Politzer, ambigüidade segundo Merleau-Ponty”.
} 
teve esta história de vida porque ele teve esta história sexual, porque este é o drama de sua $v i d a^{9}$ (assim como Merleau-Ponty dizia que a vida de Cézanne não poderia explicar sua obra, mas que ela exigia aquela vida, aquela história pessoal, para que suas obras fossem criadas (DtCz, p. 26)):

a sexualidade, diz-se, é dramática porque nela engajamos toda a nossa vida pessoal. Mas justamente por que nós o fazemos? Porque nosso corpo é para nós o espelho de nosso ser, senão porque ele é um $e u$ natural [moi naturel], uma corrente de existência dada, de tal modo que nós não sabemos jamais se as forças que nos dirigem são suas ou nossas - ou ainda, que elas não são jamais nem suas nem nossas inteiramente. Não há ultrapassagem da sexualidade como não há sexualidade fechada sobre si mesma. Ninguém está a salvo e ninguém está perdido inteiramente (PhP, p. 199).

Pensemos agora naquele outro tema importante: o fato da psicanálise nos levar a pensar que toda ação humana tem um sentido. Na verdade, isto possibilitava a Merleau-Ponty aproximar as análises freudianas da fenomenologia, algo que ele deixa explícito, por exemplo, nesta passagem:

mesmo em Freud seria um erro acreditar que a psicanálise exclui a descrição dos motivos psicológicos e se opõe ao método fenomenológico: ao contrário, ela (sem o saber) contribui para desenvolvê-lo afirmando, segundo a expressão de Freud, que todo ato humano 'tem um sentido' e buscando por todas as partes compreender o acontecimento ao invés de reatá-lo a condições mecânicas (PhP, pp. 184$185)^{10}$.

Do mesmo modo, Merleau-Ponty nos diz em relação à significação sexual: há um sentido no sonho, mas esta significação não é uma relação simbólica como o símbolo é pensado para um homem desperto (PhP, p. 437). Para Merleau-Ponty, trata-se de um valor afetivo, onde tudo é simbolizado por tudo em nossa existência (DtCz, p.32) e onde o saber objetivo se perderia em fixar uma simbolização unívoca. Ou como diz noutro lugar (em 19541955):

\footnotetext{
${ }^{9}$ É por isso que Merleau-Ponty afirma que, "no caso da psicanálise, trata-se de restituir a história de um indivíduo, de redescobrir os eventos essenciais de uma vida, os traumatismos e os mecanismos de defesa pelos quais o indivíduo se opõe a essas pertubações. Este é o objeto de uma verdadeira arte: o psicanalista é um prático" (Sorb, p. 328).

10 “(...) Freud considera a emoção como uma ação ou uma realização simbólica. Ele mostra assim (sabemos que é uma destas fórmulas que permite um meio de relacionar sua tentativa daquelas dos fenomenólogos) que 'os fatos psíquicos têm um sentido' e devem ser submetidas a um deciframento. Ele ensaia de as reintegrar [as emoções] na vida total do sujeito (...)” (ShPh, p.p. 78-79).
} 
o essencial do freudismo não é ter mostrado que há sob as aparências uma outra realidade, mas que a análise de uma conduz a encontrar sempre mais camadas de significação, que elas têm todas suas verdades, que a pluralidade de interpretações possíveis é a expressão discursiva de uma vida mista, onde cada escolha tem sempre mais sentido sem que se possa dizer que somente uma delas é verdadeira (RC, p. 71).

O essencial em Freud parece ser o fato de a psicanálise conseguir revelar as significações subterrâneas, verdadeiras, da conduta humana, onde há existência de sentidos, além do sentido manifesto (IP, p. 269). Hesnard (1960, p. 312) destaca isto muito bem: a psicanálise, na obra de Merleau-Ponty, é considerada como uma pesquisa do sentido das estruturas, que são vividas antes de serem pensadas.

Para compreendermos isto, lembremos novamente que Politzer já destacava que a psicanálise ainda trazia alguns resquícios clássicos, principalmente na noção de inconsciente. Para ele, o conteúdo latente (latenten Traumgedanken) do sonho não provaria a existência do inconsciente. Isto porque o inconsciente seria apenas uma exigência realista, já que todos os problemas da psicanálise poderiam se voltar ao concreto (POLITZER, 1968, p. 161). Neste sentido, não há nenhum conteúdo consciente ou inconsciente para Politzer, o que existe é uma significação na ação que não está dissociada do drama pessoal.

Seria assim no comportamento humano que deveríamos nos debruçar, e não em algo anterior ao próprio comportamento (POLITZER, 1968, p. 205): “(...) o conteúdo latente, quer dizer, o conhecimento do sentido do sonho não pode estar antes da análise nem consciente, nem inconsciente: ele não existe, porque a ciência não resulta da obra do sábio”. Isto significa que existe uma significação de ordem existencial (o sentido do comportamento humano), o que é bem diferente de instaurar uma instância inconsciente que supostamente motivasse minha ação.

É exatamente por aí que caminha Merleau-Ponty. Para o filósofo, é possível uma interpretação em sentido amplo da psicanálise:

o que se chama de inconsciente (...) é apenas uma significação despercebida (SC, p. 237); a noção de inconsciente cede lugar à noção de ambivalência (Sorb, p. 95); o inconsciente não é uma segunda 
consciência, mas um vivido não-tematizado (Sorb, p. 300) ${ }^{11}$. Ou ainda: o irrefletido é (...) um saber nãoreconhecido, informulado, que nós não queremos reconhecer. Numa linguagem aproximativa, Freud está aqui no ponto de descobrir o que outros melhor nomearam de percepção ambígua (HA, p. 291; PONTALIS, 1961, p. 295).

Neste sentido, Merleau-Ponty percebe de um modo muito original aquilo que Lacan desenvolve em seus primeiros trabalhos ${ }^{12}$, ao aproximar a noção de inconsciente dos problemas gestaltistas:

todo o conhecimento, diz a psicologia da forma, é a percepção de uma figura sobre um fundo. Ela deve se envolver por um halo de não conhecido ou ao menos conhecido sobre uma margem de desatenção e que não é um suplemento, mas um elemento essencial. Do fato de o objeto ser uma figura, errou-se na análise do conhecimento, por considerá-lo desprovido de um fundo. É necessário envolver o conhecimento de uma mancha de consciência que não põe o objeto enquanto objeto. Eis o vivido não denominado, o que Freud chama incorretamente de inconsciente (UAC, p. 127).

\section{Como sabemos, é certo que tudo se passa como se Merleau-Ponty buscasse alargar o}

domínio da reflexão, buscando apreender aquilo que a filosofia até então deixava de fora.

\footnotetext{
${ }^{11}$ Uma das principais razões de se criticar o inconsciente freudiano nesta época certamente tem suas origens na análise sartreana. Quer dizer, para Sartre, o inconsciente pareceria ser apenas uma hipótese inútil, que poderia ser integrada à noção de consciência. O inconsciente seria herdeiro de uma psicologia das profundezas que se identificaria a algo que estaria atrás da consciência, motivando-a, como um reservatório que determinaria a verdadeira ação do eu. Ora, este algo atrás da consciência que motivaria a ação seria uma hipótese inútil, já que o sentido do ato pode ser apreendido e aquilo que se mostrava anteriormente como algo que não se sabia mostra-se agora como algo já sabido desde sempre, inconsciente apenas temporariamente. Seria absurda uma consciência que se ignorasse ou que não soubesse de si para Sartre (2006, p. 87): “todo saber é consciência de saber”. No limite, Sartre critica a divisão da unidade psíquica, pressupondo um eu consciente e um inconsciente (SARTRE, 2006, pp. 88-89). Tratar-se-ia por outro lado de um ato de má-fé da consciência e que por isto mesmo implica em sua unidade (ver ibid., p. 83): a consciência se afetaria às vezes por este ato. Com isso, entendemos afirmações como esta: "nada ganhamos com a psicanálise, porque ela, para suprimir a má-fé, estabeleceu entre inconsciente e consciência uma consciência autônoma e de má-fé" (SARTRE, 2006, p. 87), coisificando esta operação. Merleau-Ponty não caminha por aí e critica em alguns momentos esta idéia (PhP, p. 433; Sorb, p. 474), mas a importância da crítica sartreana marcava a dificuldade de se afirmar uma "instância" inconsciente.

${ }^{12}$ Boothby nota muito claramente esta aproximação com a Gestalttheorie em Lacan. Por exemplo, ele nos diz que a análise da resistência em Le Seminaire I, nos apontava exatamente a isto: no momento em que o paciente está por falar, está por deixar emergir um pensamento primordial, ele acaba por desviá-lo. Mas como que é possível esta "substituição" de um pensamento por um outro (que não seja diretamente a lembrança de algo penoso ao paciente)? Como é possível explicar este processo de defesa? Boothby, neste ponto, nos lembra dos problemas gestaltistas: em todo campo perceptivo, sempre percebemos uma figura sob um fundo, o que, para Boothby, é tentador comparar com a ação da repressão aos processos pelos quais os conteúdos do "fundo" da consciência são relegados à "margem" (BOOTHBY, 2001, p. 73). Noutras palavras, Boothby apóia-se na idéia de defesa primária de Freud, nesta função do aparelho psíquico de desviar o destino de passagem de energia, substituindo uma imagem por outra, a um objeto menos hostil ao paciente, onde o fundamental permanece sob um fundo e a substituição aparece como figura. Em verdade, o que é substituído só emergiria sob a condição de um fundo, onde as imagens seriam associadas segundo esta função de defesa (BOOTHBY, 2001, pp. 74-75): "a figura do campo fenomenal se perde somente por virtude de ser substituída por detalhes do fundo ao seu redor" (BOOTHBY, 2001, p. 76). Haveria como que uma contigüidade de imagens, que se substituiriam por um movimento lateral, exatamente aquilo que Lacan iria entender como "metonímia". Ou, na terminologia freudiana, a catexia seria equivalente à função dos processos do campo perceptivo: haveria um investimento de energia que foca a atenção e o interesse, deixando sempre algo à margem, assim como a repressão funcionaria como num automatismo de toda estrutura ativa perceptiva (BOOTHBY, 2001, p. 77).
} 
Trata-se assim de buscar apreender o ambíguo, o vivido, exatamente o que constitui o irrefletido, segundo o filósofo (o que vale o título de uma filosofia da ambigüidade consagrado por Waelhens (1968, passim) ${ }^{13}$ ). Mas dizer de um irrefletido ou que ajo de tal modo que o "eu penso" não se reconhece seguindo uma lógica vivida, não significa dizer que exista algo como uma instância inconsciente:

a consciência não é nem posição de si, nem ignorância de si, ela é não-dissimulada a ela mesma, quer dizer que ela não é nada nela que não se anuncia de algum modo, apesar de não precisar conhecer expressamente (...); o vivido é vivido por mim, eu não ignoro os sentimentos que recalco e, neste sentido, não existe inconsciente” (PhP, p. 342-343) ${ }^{14}$.

Como vemos, a interpretação merleau-pontyana nega, inclusive, um conceito-chave do arcabouço freudiano. Mas de qualquer modo, há uma certa herança dos trabalhos freudianos que ainda deve ser destacada, mesmo que ainda aqui sua interpretação desvie da intenção do psicanalista. Interessa-me discutir a aproximação que o próprio Merleau-Ponty realiza entre o poder corporal e a libido freudiana.

Comecemos por uma definição de Freud (1953d, p. 31): “libido é um termo pertencente à teoria da afetividade. Denominamos com ela a energia, considerada como uma grandeza quantitativa - embora ainda não mensurável — das pulsões relacionadas a tudo aquilo que pode ser compreendido sob o nome de amor”.

Desta definição, podemos destacar, primeiramente, que a libido, de um ponto de vista qualitativo, não pode ser reduzida a uma energia não específica, mas somente àquelas que estão relacionadas “à teoria da afetividade”. Trata-se assim de uma energia que, como demonstra as investigações psicanalíticas, segundo Freud (1953d, p. 32), tende a ser compreendida como todo “movimento pulsional sexual”. Isto é bastante importante: para

\footnotetext{
$13 \mathrm{Na}$ verdade, o primeiro a dar este título à filosofia de Merleau-Ponty é Alquié (Une Philosophie de l'Ambiguïté: l'Existentialisme de Maurice Merleau-Ponty).

14 Ou, como resume bem Furlan (1999, pp. 128-129), “o inconsciente não será jamais um conjunto de representações [para Merleau-Ponty]; será uma forma de organizar o sentido vivido (...) que encerra conflitos e ambigüidades no modo de ser (...)”.
} 
Freud (1953c, p. 201), a libido, de um modo geral, designa "a manifestação dinâmica da sexualidade”.

Um outro ponto importante é o ponto de vista quantitativo. Seguindo claramente a psicofísica da época, Freud parece pensar que os fenômenos psíquicos poderiam ser, de certa forma, comparados aos fenômenos físicos. Entretanto, se esta energia, esta libido, estava arraigada à tradição racionalista de reduzir o psíquico ao físico, ao mesmo tempo, ela deveria ser entendida no campo sexual, e isto trazia uma diferença fundamental. Enquanto uma energia, ela só pode se manifestar num fim determinado: ela é sempre um investimento em algo ou faz com que certa quantidade de energia psíquica se encontre ligada necessariamente a alguma representação. Assim, o que importa a Freud não é somente um problema quantitativo de energia, mas também seu destino.

Quando se diz, por exemplo, de um objetivo no investimento sexual, seja qual for sua mobilidade ou sua variação de intensidade, diz-se, ao mesmo tempo, de uma “descarga de energia” ou de uma “satisfação sexual”, numa representação. Por exemplo: na sexualidade infantil, há uma pulsão sexual com um objetivo, que consiste em provocar a satisfação pela excitação de uma zona erógena específica (1952, p. 54). O fundamental aqui é compreendermos que esta satisfação está ligada a alguma representação. Claro que, na clínica, é fundamental a compreensão desta ligação ser nesta ou naquela representação. Mas no arcabouço teórico, o importante é frisar uma certa "plasticidade da libido”, ou a capacidade de mudança de objeto e também dos modos de satisfação: “a expressão da 'plasticidade da libido’ ilustra a idéia, essencial na psicanálise, de que a libido é, antes de tudo, indeterminada quanto a seus objetos e permanece sempre suscetível de mudança” (LAPLANCHE; PONTALI, 2004, 316). Ou como nos diz Birman (1984, p. 381), o investimento libidinal a um “(...) objeto que seria aquilo que existiria de mais variável e diversificado, de forma que a 
satisfação pulsional poderia se realizar através de uma grande multiplicidade de objetos, rompendo, assim, com a estrutura fixa da organização do instinto”.

Já sabemos que, em Merleau-Ponty, esta pulsão não pode ser distinguida de uma pulsão sexual e/ou não sexual. Entretanto, esta passagem da “econômica libidinal” parece ser fundamental na fenomenologia merleau-pontyana. Aquela "plasticidade libidinal" parece cumprir o papel do poder geral do corpo de investir em diferentes meios. Aliás, como a “fixação” em Freud, o neurótico, principalmente, permanece ligado a um certo modo de satisfação, a certos tipos de objetos. Como vimos, em Merleau-Ponty, a perda da capacidade de se colocar no reino do possível, ou seja, a perda da capacidade de orientar-se sobre o possível é exatamente o que para o filósofo corresponde ao patológico: à fixação num certo meio, perdendo seu poder de investir em diferentes meios. É por isso que, para Schneider, o mundo não lhe tem uma fisionomia sexual: “o que desapareceu no doente é o poder de projetar diante dele um mundo sexual, de se colocar numa situação erótica (...)” (PhP, p. 182).

Num primeiro momento, Merleau-Ponty parece seguir a pulsão sexual de Freud: “se nós queremos colocar em evidência a gênese do ser para nós, é preciso considerar, para terminar, o setor da nossa existência que visivelmente só tem sentido e realidade para nós, quer dizer, para nosso meio afetivo” (PhP, p. 180). Ou seja, assim como em Freud, a libido só tem sentido dentro de uma teoria da afetividade. Entretanto, ao pensar a libido como “(...) o poder geral que tem o sujeito psicofisiológico de aderir a diferentes meios, de se fixar por diferentes experiências, de adquirir estruturas de conduta” (PhP, p. 185, grifo meu), MerleauPonty parece assim "ampliar” a noção freudiana a um modo existencial de nos relacionarmos com o mundo de um modo geral (PhP, pp. 183; 437). Comparemos, por exemplo, esta última passagem com esta definição de corpo: “(...) meu corpo é meu poder geral de habitar todos os meios do mundo (...)” (PhP, p. 359). Neste sentido, poder-se-ia acusar Merleau-Ponty de reduzir a pulsão freudiana a um “interesse” pelo mundo. Quer dizer, “interesse” como 
“interesse psíquico em geral” em oposição à libido (à pulsão sexual). Se toda relação humana envolve uma certa sexualidade corporal, é porque o poder corporal é um poder de investir no mundo de um modo geral, estando assim Merleau-Ponty talvez mais próximo de Jung que de Freud (1953c, p. 202).

Poder-se-ia ainda acusar o filósofo de excluir a pulsão do Eu ao dizer que “a percepção erótica não é uma cogitatio que visa um cogitatum; através de um corpo, ela visa um outro corpo, ela se faz no mundo, e não em uma consciência” (PhP, p.183). Mas, na verdade, o que interessa ao filósofo, me parece, é o fato do corpo investir no mundo ou o fato da sexualidade ser co-extensiva à existência. Percebamos, por exemplo, esta passagem:

Freud foi um dos primeiros a levar a sério a criança, mostrando não que ela se explica pelas suas funções corporais mas que suas funções corporais assumem um papel numa dinâmica do psiquismo. (...) Freud quis recolocar a criança na corrente da existência de que o corpo é o veículo (Sorb, pp. 351352).

Por isso talvez não seja totalmente justa esta outra acusação de Green (1964, p. 1019): “o que Merleau-Ponty estuda são as relações do sujeito e do mundo, ligadas em forma de debate. Mas como compreender o desinteresse por esta outra face do trabalho silencioso do corpo, aquele que Freud denominou pulsional?»15. Tal questionamento não leva em conta o objetivo de Merleau-Ponty: reintegrar a sexualidade na existência e, por isto mesmo, descrevê-la enquanto um modo corporal de se relacionar com o mundo.

Ora, se Merleau-Ponty se interessa pelo tema da pulsão é para relacioná-lo ao poder geral do corpo de investir no mundo e para demonstrar como “há uma ‘compreensão’ erótica que não é da ordem do entendimento, porque o entendimento compreende percebendo uma experiência sob uma idéia, enquanto que o desejo compreende cegamente, ligando um corpo a outro corpo" (PhP, p. 183).

\footnotetext{
${ }^{15}$ Mas acompanho largamente outra tese de Green (1964, p. 1019): “tomamos a hipótese que o pensamento psicanalítico teve um papel determinante na última viragem de Merleau-Ponty”. Se pudéssemos desenvolver um trabalho da leitura merleau-pontyana da psicanálise, certamente poderíamos acompanhar como ela é determinante no desenvolvimento intelectuual do filósofo, principalmente em seus últimos trabalhos. Waelhens (1961, p. 389) nos participa: "Merleau-Ponty não cessa jamais de se interessar na teoria psicanalítica, os trabalhos de seu amigo Jacques Lacan constituem um motor essencial deste interesse”.
} 
Trata-se assim de dizer que a sexualidade nos abre a um "novo" setor do ser que só pode ser acessível para nós pela afetividade. Mas tal acesso não é “um pensamento de”, pois minha relação com o mundo e com os outros está numa “intencionalidade” que não é do nível do "eu penso que”: eu já estou engajado no mundo; meu corpo já está numa relação com o mundo. Trata-se de destacar que a sexualidade motiva minha conduta sem ser objeto expresso da minha consciência (PhP, p. 197).

Lembremos que o objetivo é dizer que a consciência é originalmente um “eu posso”, ou seja, que o movimento corporal tem um papel na percepção. Com o estudo da sexualidade, Merleau-Ponty pode assim pensar como um modo corporal de se relacionar com o mundo tem um papel na percepção do mundo: a sexualidade, “sem ser o objeto de um ato de consciência expresso, pode motivar as formas privilegiadas de minha experiência” (PhP, p. 197).

Mas ainda há de se destacar outra passagem de Merleau-Ponty neste capítulo. É no mínimo surpreendente que, ao analisar Le Corps comme Être Sexué, Merleau-Ponty inclua uma nota sobre uma “interpretação existencial do materialismo dialético”. Segundo Whiteside (1988, p. 13), isto tem um objetivo claro: “assim como as motivações sexuais espagem a conduta individual sem determiná-la, Merleau-Ponty argumenta que, também as motivações econômicas favorecem, mas não determinam as escolhas feitas por grupos”. Percebamos esta passagem de Merleau-Ponty: “se a existência é o movimento permanente pelo qual o homem retoma por sua conta e assume uma certa situação de fato, nenhum de seus pensamentos poderá ser completamente destacado do contexto histórico em que ele vive” (PhP, p. 201).

Na verdade, nos cursos de Sorbonne, este tema parece ser um ponto central no desenvolvimento da articualção entre o individual e o coletivo já apontada na Phénoménologie de la Perception, principalmente ao concordar com Freud que a psicologia das massas deveria ser pensada como a psicologia individual (Sorb, p. 280). Lembremos primeiramete de Totem und Tabu, de Freud. Ali, vemos sua tendência em desviar problemas 
claramente da clínica para problemas da teoria social, como se a verdade dos fatos psicológicos estivesse no telos social. Neste sentido, podemos ler Totem und Tabu como uma antropologia social, assim como uma teoria dos processos sociais e dos bloqueios destes mesmos processos. Seríamos desta forma forçados a admitir que a estruturação dos tabus teria a mesma estruturação dos sintomas na clínica. O que isto significa? Não há dúvida a Freud: a psicologia individual já é uma psicologia social (1953e, pp. 9-25).

Lembremos também de Massenpsychologie und Ich-Analyse. O próprio título é sugestivo ao relacionar estas duas questões (a psicologia das massas e a análise do eu) com o conectivo und. Afinal, lá onde se esperava uma autonomia dos conflitos, na psicologia das massas, Freud vê uma indistinção entre os problemas individuais e os problemas sociais: a própria clínica da subjetividade é uma clínica dos fenômenos sociais (pois não haveria fatos psicológicos legíveis sem estes fenômenos). Sendo assim, o que está no interior da clínica é um fenômeno social desde o início, como, por exemplo, no déficit da fala — o que estaria em jogo seria o déficit dos processos de identificação social. Isto porque, a seu ver, cada instância maior na sociedade, como por exemplo o Estado, está em germe ali na família. Merleau-Ponty explica isto nestes termos: “a relação parental é o veículo de todas as relações com o mundo e é no interior dessa relação que se manifestam as relações sociais” (Sorb, p. 379).

Neste primeiro meio social seria onde começaríamos nossas interações (nossas internalizações da lei, nossa identificações, onde será possível, na formação do eu, dizer de um dispositivo de auto-referência, resultado deste processo de socialização ${ }^{16}$ ). Como o próprio Merleau-Ponty lê da análise freudiana:

as relações da criança com seus pais constituem a matriz das relações com os adultos. Os pais são os pivôs, os pontos cardiais da vida infantil. Os demais adultos são eles próprios considerados como personagens parentais. A criança recomeça com o adulto sua experiência da vida familiar. As relações com os pais são mais do que relações com duas personagens, elas são relações com o mundo. Os pais são os medidores das relações com o mundo. Esse ponto merece ser destacado, porque nem sempre surge na obra dos psicólogos (Sorb, p. 331).

\footnotetext{
${ }^{16}$ Lacan parece radicalizar esta idéia, como nos diz Ogilvie: da sociedade à família, da família ao "espelho”. (OGILVIE, 1987, p. 96).
} 
Notemos que Merleau-Ponty participa desta problemática de Freud. É exatamente isto que ele nos diz ao estudar a passagem de Édipo à fase de latência:

não há meio de desenvolvimento senão na presença dos pais em torno da criança, e da cultura que eles vinculam até ela. (...) Não há um único fato da psicologia individual que não seja um fato da psicologia social. (...) O social é interior ao individual, e o individual é interior ao social, pois o passado individual é ele mesmo inter-psicológico desde o nascimento, e que, por outro lado, toda atitude típica, dada pela sociedade, pode sempre ser modificada pelo poder individual, o que explica a evolução cultural da sociedade. (...) Não há fronteiras: tudo é social e tudo é individual (Sorb, p. 282).

Isto é muito importante aqui para entendermos como podemos dizer que o corpo, além de ser este corpo encarnado, situado no mundo, num único ponto de vista no mundo, é também um corpo de um sujeito que tem uma história, que esta história pessoal está inserida na história social donde este sujeito se desenvolveu. Isto permite a Merleau-Ponty afirmar que “existe, portanto, uma relação entre o corpo e o sujeito total. O corpo deve ser considerado um espelho, a expressão do psiquismo de todo o sujeito, a expressão de uma história psicológica. O desenvolvimento anônimo do corpo não é nada enquanto ele não for integrado à sua história psicológica” (Sorb, p. 505). Sendo assim, é preciso doravante considerar os fenômenos psicológicos e os fenômenos sociais sem podermos entretanto reduzir um ao outro (Sorb, p. 290).

“Os conflitos psicológicos não são exteriores aos fatos sociais” (Sorb, p. 383). Esta é uma questão profunda, porque implica que a sexualidade, sozinha, jamais poderia explicar o drama individual ou o desenvolvimento infantil, por exemplo. "O homem vive com tudo que ele é: seu passado infantil, seu temperamento, sua conduta social” (Sorb, p. 380). Ou seja, as funções gerais de nossa vida, assim como nossa história individual e a história na qual estamos inseridos, são solidárias umas às outras e estão numa relação de “osmose” com nossa existência a tal ponto que só podemos definir o homem por sua experiência. Assim, se Schneider perdeu seu poder de reconhecer a "fala" do mundo, do mesmo modo ele perdeu o poder de reconhecer a "fala” dos eventos humanos e dos outros (PhP, p. 154) — os outros são como “fantasmas” a ele, pois nada lhe dizem (PhP, p. 155). 
Para onde isto nos aponta? Certamente numa posição ambígua: nós sempre somos motivados pelo mundo, por nossa história, pelo meio em que vivemos, mas, ao mesmo tempo, temos liberdade, que não destrói nossa situação, mas que engrena as motivações (PhP, p. 505). É porque sempre nossa situação é de abertura, assim como sempre foi nossa situação corporal diante de um campo fenomenal. Ora, a psicanálise nos remete exatamente a isto: a um indivíduo em situação em certo meio familiar. Se por um lado ele é determinado por internalizações de leis, por exemplo, por outro a libido, tal como Merleau-Ponty nos aponta, como um “poder geral”, é exatamente o que torna possível nossa liberdade frente a estas internalizações —é possível investir num outro meio.

\section{6) A consciência perceptiva operando num modo "indeterminado"}

Na discussão do problema da imitação, do hábito corporal, do ato expressivo e do corpo libidinal, pudemos compreender o que significa, para Merleau-Ponty, dizer de um “poder corporal”: trata-se de um certo “investimento”, “engajamento”, do corpo no mundo, porque o corpo é um sistema de ações possíveis e é capaz de habitar todos os meios possíveis. Entendemos melhor também aquele "saber corporal”: o corpo age sem que seja preciso uma consciência explícita desta ação, porque o corpo já está engajado no mundo, já está polarizado a ele enquanto potência perceptiva. Lembremos: “compreender” é experimentar o acordo entre o que nós visamos e o que é dado, entre a intenção e a efetuação (PhP, p. 169). Sendo assim, o corpo já está orientado ao mundo, já visa uma meta espontaneamente pelo poder que tem de habitar os meios visados.

Entretanto, nosso objetivo neste capítulo era entender como "o movimento do corpo não pode ter um papel na percepção do mundo se ele mesmo não é uma intencionalidade 
original, um modo de se relacionar ao objeto distinto do conhecimento” (PhP, p. 444). Isto significa que toda percepção envolve o movimento corporal enquanto intencionalidade do "eu posso". Como clarearmos isto?

Dizíamos no primeiro capítulo que o corpo é o sujeito de percepção. Isto significava que toda síntese perceptiva se realiza numa zona que sempre nos escapa (PhP, p. 382), porque está aberta a uma temporalidade que perpassa o presente vivo do sujeito. Vimos como esta síntese contava com nossa perspectiva espacial e temporal, e como ela operava numa “transição temporal” a partir deste presente vivo. Quer dizer, em toda síntese há uma retensão de um passado e a protensão de um futuro.

Esta mesma idéia foi delineada neste capítulo, não só, segundo uma perspectiva espacial e temporal, mas levando em conta também o papel do movimento corporal na percepção. Trata-se de uma passagem crucial: todo hábito perceptivo é também um hábito motor (PhP, p. 177).

Foi exatamente isto que esboçei neste capítulo: só se pode dizer de um poder corporal a partir de uma “sedimentação”, ou seja, a temporalidade é capaz de ligar nosso campo de visão e nosso campo de ação: "Husserl avança a idéia de uma síntese de transição (Übergangssynthesis). Nós efetuamos com nosso corpo a transição; é o ich kann” (HNN, p.221). Toda percepção supõe assim um certo passado do sujeito que percebe e uma projeção possível diante de um presente (PhP, p. 326). A percepção “goza de um saber habitual do mundo”. Mas reparemos o papel da temporalidade aqui: “a síntese perceptiva é para nós uma síntese temporal, a subjetividade, no nível da percepção, não é outro que a temporalidade e é isto que nos permite de ligar o sujeito da percepção à sua opacidade e sua história” (PhP, p. 276).

Isto significa, antes de tudo, que meu corpo dispõe de um passado que me é presente em toda conduta. O sujeito de percepção, meu corpo, no modo originário da consciência, 
enquanto "eu posso" ${ }^{17}$, dispõe de um passado que pode retomar, sem que seja preciso uma consciência explícita deste passado, e de uma ação possível que pode se engajar a todo o momento.

É por isso que dizíamos de um “saber corporal”: meu corpo compreende a lógica do mundo justamente por ter um “saber sedimentado”. Ou seja, em toda percepção, se retoma um saber adquirido (PhP, p. 275) sem se dar conta disto. Basta que lembremos do exemplo do cigarro no começo do capítulo: eu não preciso me perguntar sobre qual braço devo estender para solicitá-lo. Ou do exemplo do automóvel: eu não represento o espaço por onde passo com meu carro, porque sei seu volume e sei que ele passa por este beco.

Reparemos na importância deste tema. Se, por um lado, há um poder corporal, então é possível esboçar uma “história pessoal”, mas esta história conta com um passado já sedimentado (eu ajo a partir dela):

posso fechar os olhos, tapar os ouvidos, mas não posso deixar de ver, nem que seja o negro de meus olhos, de ouvir, nem que seja este silêncio, e da mesma maneira posso colocar entre parênteses as minhas opiniões ou minhas crenças adquiridas, mas, o que quer que eu pense ou decida, será sempre sobre o fundo daquilo que anteriormente acreditei ou fiz (PhP, p. 453).

Por outro lado, o saber corporal nos leva a pensar a percepção como não-tética, pré-objetiva, pré-consciente (PhP, p. 279). Ou melhor: que a percepção se dá sempre num modo indeterminado (on) ( $\mathrm{PhP}, \mathrm{p} .277)$. Isto porque, se meu corpo compreende a lógica do mundo, já está polarizado numa ação, então não se trata de uma decisão pessoal minha perceber assim ou de outro modo - é o mundo que se dispõe deste modo que percebo (é ele que dispõe um

\footnotetext{
${ }^{17}$ É interessante vermos críticas feministas ao "eu posso" merleau-pontyano, afirmando, por exemplo, como Young, que a mulher não tem esta mesma "abertura" que o homem. Ela diz de uma "intencionalidade inibida" da mulher, o que levaria a mulher a se relacionar com o mundo segundo duas possibilidades: I can; I cannot (YOUNG, 1989, pp. 58-62). A meu ver, Young não compreende que este "eu posso" é uma descrição do papel do movimento corporal na relação com o mundo: não interessa exatamente o que o corpo faz, mas o fato da motricidade ter um papel nesta relação. Não se trata de identificar o papel do masculino e do feminino, mas de mostrar que o corpo está engajado no mundo antes de qualquer decisão minha (antes mesmo de nos identificarmos como homem ou mulher). Mas certamente seria curioso podermos ver até onde poderíamos diferenciar uma sedimentação cultural entre os papéis masculino e feminino em relação ao cuidado de si, do corpo, por exemplo.
} 
sentido latente, que me motiva a agir). Para Merleau-Ponty, isto significa que toda percepção tem lugar numa atmosfera de “generalidade” e se dá a nós como anônima (PhP, p. 249).

Se dizemos assim de um sujeito corporal, deve-se entender, como Barbaras (2005a, pp. 228-229), que

\begin{abstract}
a fórmula ‘eu sou meu corpo’ significa que o ‘eu’ é seu corpo, que o ser da subjetividade é aquele do corpo, não como objeto, mas como transcendência versus um mundo. (...) Dizer que o ‘eu’ é seu corpo é reconhecer que ele não cessa jamais de ser 'indeterminado’ [on], que uma névoa de anonimato continua a envolver os atos mais temáticos e que o conhecimento retém sempre alguma coisa da adesão global ao mundo do qual emerge.
\end{abstract}

Todo ato perceptivo precede assim qualquer ato pessoal: o poder de agir pressupõe que já se compreenda o sentido do mundo. É certo que não sou eu, enquanto sujeito autômato, que dou um sentido a ele, sou eu, enquanto tenho um corpo, enquanto conto com este “instrumento geral de minha compreensão” (PhP, p. 272), que compreendo o sentido que o mundo se apresenta a mim (PhP, p. 277). “Ao enformar significamente a experiência vivida, o corpo determina virtualmente o sentido de toda experiência possível, e o faz de modo independente do sujeito cognitivo” (FERRAZ, 2006, pp. 89-90). “Independente” porque, na percepção, retoma-se, espontaneamente, algo adquirido em minha história ( $\mathrm{PhP}, 275)$, algo que se perdeu (enquanto consciência explícita) na temporalidade do corpo (PhP, p.382). É por isso que eu percebo independentemente de qualquer tomada de posição voluntária (FERRAZ, 2006, p. 90).

Entretanto, enquanto um corpo aberto às ações, é possível retomar aquilo que está sedimentado, e projetar, diante de si, as sitações possíveis em resposta a um mundo que o corpo compreende. É possível escrever uma nova história, e é este o modo original da consciência enquanto “eu posso”. 


\section{Quarto capítulo - A consciência da unidade corporal e a consciência de si}

\section{1) A consciência da unidade corporal}

No último capítulo, vimos como o corpo está aberto ao mundo no modo original da consciência (enquanto “eu posso”). Mas devemos ainda perguntar: é possível estarmos aberto ao mundo sem termos consciência de nós mesmos? Ou: é possível dizer, ao mesmo tempo, de uma consciência de si e do mundo?

Para respondermos isto, penso que seria interessante questionarmos o como nos tomamos enquanto uma unidade corporal em nossas condutas. A partir daí, talvez possamos vislumbrar o modo que tomamos consciência de nós mesmos. Esta passagem, a meu ver, merece um capítulo em especial.

Sabemos que a psicologia cunhou um termo para designar esta unidade do corpo: o esquema corporal. Se o corpo é um todo e age como um sistema integrado onde todas as partes são solidárias às outras, assim como todos os sentidos são solidários uns com os outros, é porque existe um esquema que integra esta unidade. Esta idéia é algo que Merleau-Ponty encontra nas pesquisas contemporâneas a si, como por exemplo em Head, Wallon, ou mesmo em Lhermitte e Schilder. Segundo o filósofo, ao pensar o esquema corporal,

elas [as pesquisas contemporâneas a ele] fazem do corpo o lugar de uma certa práxis, o ponto a partir do qual há alguma coisa a fazer no mundo, o registro onde nós estamos inscritos e continuamos nos inscrevendo, e pelo qual elas renovam nossa idéia de espaço e movimento. O corpo é a cada momento, dizia já Head, a construção global de um trajeto percorrido, ele é também o que nos permite instalar antecipadamente na posição a qual tendemos (...) (RC, p. 16) 
Noutras palavras, o esquema corporal é o que nos possibilita agir devido a um "saber” corporal da minha unidade no espaço e no tempo (PhP, p. 363). Por exemplo, quando dizemos que não é preciso que eu meça o quanto devo abaixar diante de um galho no meu caminho, digo que há um “saber” do corpo da sua potência volumosa. Ora, não basta dizermos que estamos orientados versus um mundo, que estou aberto ao mundo, a ações possíveis, é necessário pressupomos um saber do corpo enquanto uma totalidade, pois "eu me sirvo dos meus dedos e de meu corpo inteiro como um só órgão” (PhP, p. 121). Isto é algo fundamental que Lhermitte (1998, p. 11) já colocava nestes termos em 1939: “como poderíamos agir sobre o mundo exterior se não estivéssemos em posse de um esquema de nossas atitudes e de nossa situação no espaço, se nós não tivéssemos presente no nosso espírito a idéia de nosso corpo?”

Seria como se houvesse uma consciência de uma unidade de existência, diferente de uma “soma de sensações" ou de uma “cinestesia”, que apenas nos traria um saber fragmentário (somatório, de partes extra partes) do corpo. O saber que temos do nosso corpo é um saber de uma totalidade: todo meu corpo se polariza na ação de desviar daquele galho. Para isso, é preciso que eu movimente vários músculos ao mesmo tempo sem me perguntar qual exatamente eu movi: é porque ajo como um todo. Certamente há um entrelaçamento das diferentes partes do corpo que tornaria cada uma de suas partes "cúmplices” das outras: ao me desviar deste galho, movo vários músculos ao mesmo tempo. Numa palavra: há uma conexão viva no corpo ${ }^{1}$ (onde cada membro reenvia a outro e não a uma soma de partes (PhP, p. 237)), algo que Kant (1960b, § 65) parece ter sugerido quando afirmava uma “auto-regulação” dos órgãos dos seres (als Organisiertes und sich selbs organisierendes Wesen) ou numa

\footnotetext{
${ }^{1} \mathrm{O}$ que Merleau-Ponty quer nos mostrar, afinal, é que o corpo é um todo, age como um todo. Por isso, como observa com acuidade Dillon, há uma certa lógica de reintegração da totalidade das funções do corpo que em $L a$ structure du comportement surge com os "processos circulares" do organismo, que era "(...) concebido sob o título de 'relação dialética'; mais tarde, na Phénoménologie de la perception, isto é refinado e generalizado pela assimétrica relação de Fundierung [PhP, p. 148, 451], e, finalmente, em Le visible et l'invisible, torna-se a tese da reversibilidade da carne" (DILLON, 1991, p. xvi). Na verdade, acompanhamos Dillon até certo ponto, pois se entendermos que esta dialética tem por base a Gestalttheorie, ou seja, da compreensão dos "processos circulares" como processos que seguem uma "forma", sabemos que isto já implica na "lógica" husserliana de Fundierung de algum modo.
} 
“solidariedade” dos órgãos entre si no organismo (o que o diferenciava da matéria em geral. No limite, isto reafirma a noção holistic de Goldstein, ou o Fundierung de Husserl, ou a noção de l'existence totale de Merleau-Ponty, porque todas as funções do homem seriam solidárias (PhP, p. 198).

Na verdade, o esquema corporal já estava pressuposto quando dissemos que a orientação corporal envolve uma certa intencionalidade: se me movo sem representar o espaço, é porque na própria motricidade há um certo saber dinâmico do corpo. O corpo assume uma postura em vistas a uma certa tarefa atual ou possível diante de uma situação (PhP, p. 116):

se meu corpo pode ser uma 'forma' e se ele pode ter diante de si figuras privilegiadas sobre fundos indiferentes, é enquanto ele polariza para suas tarefas que ele existe em direção a elas, que se encolhe sobre si mesmo para atingir sua meta, e o 'esquema corporal' é finalmente uma maneira de exprimir que meu corpo está no mundo (PhP, p. 117).

Neste sentido, contamos sempre com um saber ou uma consciência da unidade do corpo que torna possível que eu aja de um modo coerente a todo o momento: “um 'esquema corporal' ou 'postural' nos dá a cada instante uma noção global prática e implícita das relações de nosso corpo e das coisas (...)” (TT, p. 39).

Por exemplo, sei que é preciso esticar meu braço para alcançar este cigarro na minha frente, mas não preciso me perguntar desta distância: conheço a extensão do meu braço e sei que posso me deslocar até este cigarro. Quando digo que este cigarro está “aqui” ou “ali”, está “acima” ou "abaixo”, estou me referindo às coordenadas de minha situação, do meu corpo face a uma tarefa: se tento alcançar este cigarro "aqui” na minha frente, é porque há, ao mesmo tempo, uma orientação espacial do meu corpo e um saber da espacialidade da situação (PhP, p. 117). Por isso Merleau-Ponty pode afirmar um “sistema” entre meu corpo e o mundo: “a noção que tenho do meu corpo é um sistema, um esquema que comporta a relação da posição do meu corpo no meio ambiente” (Sorb, p. 311). Isto também é importante para diferenciar a espacialidade corporal da espacialidade das coisas ao meu ao redor: há uma 
espacialidade de situação (própria ao corpo próprio) e uma espacialidade de posição (própria ao objeto).

Mas o esquema corporal envolve também um entrelaçamento entre todas as minhas sensações. Quando dizíamos, por exemplo, que a percepção da cor nos leva a uma certa atitude, isto já ficava claro: é porque algo que vejo me motiva a agir (como um todo) de um certo modo. “Os diferentes domínios sensoriais interessados na percepção do meu corpo envolvem algumas relações: o esquema corporal me fornece a respeito disto, um sistema de equivalências” (Sorb, p. 311).

No estudo da criança, isso fica mais claro: “com efeito, a criança serve-se de seu corpo como de uma totalidade, sem distinguir entre o que é dado pela vista, o ouvido etc; não há multiplicidade de sensações (...). O fato pelo qual a criança pede para ver um som que ela ouviu implica a existência de relações intersensoriais” (Sorb, pp. 188-189). Isto significa que “graças a esta unidade do corpo, as percepções tácitas obtidas por um órgão são de repente traduzidas na linguagem dos outros órgãos” (PhP, p. 366). Ou seja, meu corpo é como um sistema de equivalências e de transposições intersensoriais:

os sentidos se traduzem um no outro sem ter a necessidade de uma interpretação (...) (PhP, p. 271); (...) o esquema corporal é justamente este sistema de equivalências, este invariante imediatamente dado o qual as diferentes tarefas motoras são instantaneamente transponíveis (PhP, p. 165).

Isto é algo que podemos participar também com Paul Schilder (1950, p. 38), porque, aos seus olhos, isolar uma sensação é algo sempre secundário: “no esquema corporal tátil-cinestésico, os impulsos ópticos só podem ser separados um do outro por métodos artificiais”.

Podemos então resumir o esquema corporal como aquilo que nos dá uma certa consciência de unidade, assim como o que nos dá consciência do nosso corpo no espaço e como a unidade que envolve todos os meus dados sensoriais (Sorb, p. 189).

Mas se é um fato que agimos enquanto uma unidade corporal, como tomamos consciência desta unidade? 
Este ponto, a meu ver, além de Merleau-Ponty não destacá-lo muito, parece-me também ambíguo. Num momento, ele diz que “só apreendemos a unidade do nosso corpo na unidade da coisa, é a partir das coisas que nossas mãos, nossos olhos, todos os nossos órgãos dos sentidos nos aparecem como tantos instrumentos substituíveis” (PhP, p. 372). Ou seja, a partir da experiência intersensorial, podemos apreender a unidade do corpo por um sistema de equivalências intersensoriais. O caso da experiença da criança seria privilegiado assim.

Entretanto, noutro momento, ele diz que “a síntese do objeto se faz através da síntese do corpo próprio, ela é sua réplica ou seu correlato, e, literalmente, é a mesma coisa perceber uma única bola e dispor dos dois dedos como de um órgão único” (PhP, p. 237). Isso equivale afirmar que há um "sistema” entre meu corpo e o mundo (PhP, p. 236): como se o mundo viesse, sem cessar, assaltar e invadir a subjetividade, “(...) assim como as ondas envolvem um destroço na praia” (PhP, p. 240). Haveria assim uma correspondência vivida, pois o mundo me seria dado como se fosse parte de mim: entre o corpo e o mundo haveria uma relação de totalidade, onde as partes seriam dependentes umas das outras. Em outras palavras: "toda percepção exterior é imediatamente sinônima de uma certa percepção de meu corpo, assim como toda percepção de meu corpo se explica na linguagem da percepção exterior” (PhP, p. 239). Isso torna possível ao filósofo dizer que “a teoria do esquema corporal é implicitamente uma teoria da percepção” (PhP, p. 239).

Este fato parece também verificado no distúrbio do esquema corporal, pois esta correlação também seria perturbada: tanto se pode dizer que a síntese do corpo implica num distúrbio da síntese das coisas, como o inverso (PhP, p. 238). Isso frisa que elas são correlativas: “a percepção exterior e a percepção do corpo próprio variam conjuntamente porque elas são os dois lados de mesmo ato” (PhP, p. 237).

Ainda num outro momento, Merleau-Ponty afirma que a consciência perceptiva está “ocupada” demais com o mundo para perceber o próprio corpo: 
o corpo por ele mesmo é apenas uma massa obscura, nós o percebemos como um ser preciso e identificável quando ele se move em direção a uma coisa, enquanto ele se projeta intencionalmente para o exterior, e isso, aliás, sempre pelo canto do olho e na margem da consciência, cujo centro é ocupado pelas coisas e pelo mundo (PhP, p. 372).

De um modo ou de outro, estas passagens não nos dizem muita coisa. Há, por outro lado, um caso, em especial, que merece nossa atenção, e talvez possa nos indicar melhor como esta tomada de consciência do corpo se dá: trata-se do caso do membro fantasma.

\section{2) A quase presença do corpo - o membro fantasma}

Esta unidade corporal, este esquema corporal, pode ser verificada na análise do comportamento de um amputado que Merleau-Ponty utiliza em seu estudo. Trata-se do problema do “membro fantasma”. Este problema é especificamente interessante porque envolve explicitamente a relação do corpo com o mundo (relação exterioceptiva), a relação do corpo consigo próprio (relação proprioceptiva) ${ }^{2}$ e a consciência de uma unidade corporal que o amputado tem de si, sem nos deixarmos esquecer que a "perda" de um membro pode envolver uma re-estruturação do organismo, mas também do esquema corporal, o que, em muitos casos, envolve um certo "trauma” na pessoa.

\footnotetext{
2 "A sensibilidade do próprio corpo é a que Sherrington chamou proprioceptiva, por oposição à sensibilidade exteroceptiva, que está voltada para o exterior e que tem por órgãos os sentidos. A cada uma das duas correspondem formas de atividades musculares distintas, ainda que estritamente conjugadas”. (WALLON,1998, p. 65) Sob o conceito sherringtoniano estão ligadas as reações do equilíbrio e as atividades com suporte de contração tônica dos músculos, sob a união recíproca da sensibilidade. Quer dizer, é um domínio de atividade funcional, sendo seus gestos ainda sem uma finalidade específica ao meio, mas sendo base da vida afetiva de adulto. Este domínio contribui em grande parte para a noção de corpo próprio na criança: há um sistema sinergético de movimentação e de atitude. Por exemplo: no deslocamento de um braço, desemboca uma atitude de equilíbrio de todo o corpo, devido às resistências deste deslocamento. No outro domínio, mais complexo, estão as relações com as impressões esteroceptivas e seus movimentos conjugados, sob um sistema de conexões que dependem logicamente da maturação orgânica, operando uma ligação entre as sensações produzidas ou modificadas por ela própria e a sensibilidade e o movimento da criança: a cada sensação suscita um movimento e a cada movimento suscita uma sensação (numa relação circular), "assim, a criança aprende a fazer uso dos seus órgãos sob o controle de identificar melhor cada uma das suas sensações, produzindo-a diferentemente das anteriores" (WALLON, 1998, p. 66).
} 
Se a análise merleau-pontyana parte da vivência, do mundo vivido pelo sujeito, então não podemos fugir desta pergunta: o que sentem os amputados? O que eles nos descrevem desta experiência?

Um exemplo desta descrição podemos tomar de Jaspers, numa obra importante da psiquiatria (Allgemeine Psychopathologie), com bases “fenomenológicas”3:

é assombroso como se sentem os membros amputados. Trata-se da ação do esquema corpóreo habitual que permanece após a amputação. É que o esquema corpóreo não é um simples saber flutuante, relativo ao próprio corpo, e sim um modo de apreender, profundamente implantado durante toda a vida, no qual as diversas sensações corpóreas constituem um todo. Assim como cremos ver no ponto cego normal do olho, assim o membro perdido continua sentindo como real, preenche-se a lacuna realmente aberta no esquema corpóreo (JASPER, 1973, p. 111).

Se isto estiver correto, podemos entrever o que está em jogo aqui: um problema do esquema corporal do amputado, devido uma lacuna na relação entre o “corpo habitual” e um suposto “corpo atual”. O amputado tomaria o corpo habitual como seu corpo real, levando-o a agir segundo uma compreensão da sua unidade corporal como uma unidade habitual. A lacuna seria exatamente a não atualização ou a resistência em não se tomar segundo a reestruturação do corpo amputado.

Na verdade, Merleau-Ponty compreende este fenômeno de um modo curioso. Para o filósofo, o fato de o amputado agir como se o membro ainda permanecesse, demonstra que o sujeito age segundo um modo comportamental ou um estilo de ser habitual, recusando o fato de seu corpo estar amputado. O problema é compreender por que o amputado age como se: por que esta recusa de se tomar segundo seu corpo atual?

Segundo a tradição cartesiana, como sabemos, há apenas duas possibilidades para compreender este fato: poder-se-ia tratar de um problema fisiológico ou de um problema

\footnotetext{
${ }^{3}$ Tomamos esta descrição devido a sua singular objetividade e influência em sua época. Sabemos também que a fenomenologia de Jasper é, antes de tudo, uma descrição dada pelo paciente: algo "da vivência psíquica individual" (que ele mesmo diz não corresponder exatamente às exigências husserlianas). De qualquer modo, tal passagem nos é muito útil, já que, como ele mesmo diz, é bem distante da descrição "científico-natural" (JASPER, 1973, pp. 71-74). Para um estudo sobre a relação da fenomenologia e a psicopatologia em Jasper, ver Spiegelberg (1972, pp. 173-191).
} 
psíquico (já que os únicos habitantes cartesianos são o corpo e a alma). Merleau-Ponty baseiase na obra L'Image de Notre Corps, de Lhermitte (1998), na compreensão deste problema.

Segundo o psicólogo, no primeiro caso, diríamos de uma “supressão” ou "persistência” de um estímulo interioceptivo ${ }^{4}$. No segundo, o membro fantasma seria apenas um "índex”, ou uma lembrança. O amputado agiria como se houvesse ainda um membro, porque representaria este membro para si ou este membro permaneceria latente devido à lembrança que tenho dele na imagem corporal. Nos termos de Lhermitte (1998, pp. 122-124), trata-se, de um lado, de uma teoria fisiológica e, do outro, do espírito cartesiano: se por um lado, para a fisiologia clássica, existia um “corpo real” que só poderia ser pensado a título de uma "representação" (que está nos confins dos acontecimentos físicos e fisiológicos), por outro o membro fantasma traria (ou mesmo seria) um comportamento (ou uma experiência) que só poderia ser entendido ou como um “fato psíquico”, ou todo o problema seria apenas um problema de “substituição de estímulos” (LHERMITTE, 1998, pp. 90-91).

\footnotetext{
${ }^{4}$ Wallon (2002, pp. 33-40; 187-191) descreve este outro domínio (algo que, até onde sei, não aparece em Sherrington). Este domínio é das atividades centradas, por exemplo, no sono e nas funções de nutrição; ou seja, na sensibilidade visceral. Este é um correlato do desenvolvimento psíquico, relacionado ao tubo digestivo, à alimentação, circulação e a seu primeiro reflexo, a respiração. Nessa sensibilidade primordial, a criança, por exemplo, aprimora a atividade bucal, ficando absorvida pelo movimento da boca e da faringe; com alguns meses, passará a sorrir e a interromper a sucção por ocasião de barulhos (demonstrando já um desenvolvimento esteroceptivo). Quer dizer, os órgãos da sensibilidade interoceptiva irão ser os mesmos que irão atuar na sensibilidade proprioceptiva e esteroceptiva. Aqui Wallon também vê um papel de "despertar". A curiosidade e o prazer da criança, tanto na micção, como na dejeção, parecem acompanhar um certo desejo, expectativa ou angústia. Também é importante esta sensibilidade na distinção de seu próprio corpo com o mundo exterior: pois expelir algo interno, acompanhado com um certo prazer, certamente é marcado por um elo sensível de atividade corporal. Tese, aliás, próxima de Freud: “dando à 'chupeta' toda sua importância e significação, descobrimos dois essenciais caracteres da sexualidade infantil. Une esta especialmente com a satisfação das grandes necessidades orgânicas e se comporta, ademais, de um modo auto-erótico, isto é, descobre seus objetos em seu próprio corpo. Aquilo que nos há revelado com máxima claridade na absorção de alimentos se reproduz parcialmente nas excreções. Deduzimos, pois, que a criança experimenta uma sensação de prazer ao realizar a eliminação da urina e dos excrementos, e que, portanto, tratará de organizar estes atos de maneira que a excitação das zonas erógenas a elas correspondentes exerça o maior prazer possível. (...) A criança não experimenta repugnância alguma por seus excrementos, os quais considera como uma parte de seu próprio corpo; se separa delas contra a sua vontade e os utiliza como primeiro 'regalo', com o qual distingue aquelas pessoas que aprecia particularmente” (FREUD, 1953b, pp. 78-9). Isto o levará a concluir numa fase narcísica: "sabemos que muitas tendências sexuais recebem no princípio uma satisfação que denominamos auto-erótica, isto é, uma satisfação cuja fonte é o corpo mesmo do sujeito, sendo precisamente esta atitude para o autoerotismo o que explica o atraso com que a sexualidade se adapta ao princípio da realidade inculcado pela educação. Resulta, pois, que o auto-erotismo é a atividade sexual da fase narcísica da fixação da libido" (FREUD, 1953b, p. 172).
} 
Numa tentativa de fugir desta alternativa entre fenômenos físicos e fenômenos psíquicos, Lhermitte parece sugerir uma tese mista: psico-fisiológica. O psicólogo se baseia em Paul Schilder e em sua tendência em unir a vida psíquica (da consciência e do inconsciente) com as funções orgânicas (do corpo) ${ }^{5}$. Isso lhe parece indicar um esquema corporal onde se envolveriam todas as possibilidades da vida humana (SCHILDER, 1950, p. 34), o que levava o psiquiatra a buscar na obra freudiana um modo de relacionar estes dois domínios.

Sua tese era a de que a recusa do amputado de se tomar segundo a imagem corporal atual do corpo seria uma recusa da ordem de um recalque orgânico ou, ainda, de uma repressão orgânica (SCHILDER, 1950, pp. 32-33; LHERMITTE, 1998, pp. 146-147) (o que envolveria, ao mesmo tempo, o fisiológico e o psíquico). A repressão orgânica seria um fenômeno que

(...) sobre o plano estrutural, repete o que se passa nos outros modos de recalques que nos situam no plano do psiquismo. Esta repressão orgânica focal, assim como toda repressão orgânica em geral, acompanha muitas vezes atitudes psíquicas as quais são em parte idênticas àquelas que condicionam a repressão psíquica. O fenômeno é assim baseado sobre a solidariedade profunda pela qual se ligam a vida psíquica e a vida orgânica (SCHILDER, 1950, pp. 32-33).

O problema do membro fantasma não seria então apenas um problema adaptativo, mas de desejos inconscientes (ou não tematizados pela consciência) que estariam enraizados nas lesões orgânicas (LHERMITTE, 1998, p. 146). Deste modo, Lhermitte (1998, p. 146) acreditava resolver finalmente este problema, unindo o físico e psíquico, através da união do orgânico e do psíquico, fugindo do mundo clássico cartesiano.

Para Merleau-Ponty, embora negando tanto uma explicação fisiológica como uma psicológica pura (PhP, p. 92), esta tese ainda está inserida no mundo objetivo (PhP, pp. 9596), evitando os paradoxos da experiência do amputado. Isso porque, segundo o filósofo, o

\footnotetext{
${ }^{5}$ Spiegelberg (1972, pp. 319-331) faz um bom resumo desta tendência de Schilder em convergir os problemas freudianos aos problemas somáticos.
} 
psicólogo, mesmo encontrando uma teoria que denomina central (LHERMITTE, 1998, p. 124), basearia sua tese em dois prejuízos:

1. não foge do objetivismo científico ao tentar determinar o problema assim como um físico determina uma coisa;

2. e, principalmente, baseando o problema do membro fantasma numa teoria temporal clássica, supondo sempre a idéia de que aquele membro é um resíduo, uma lembrança que se inscreveria no esquema corporal (porque a imagem de nosso corpo seria mais resistente que nossa morfologia (LHERMITTE, 1998, pp. 124-126)) e que se formaria a partir de representações galgadas nas percepções residuais (LHERMITTE, 1998, p. 137).

Para Merleau-Ponty, esta teoria estaria inserida na tradição de tomar os resultados (a representação da imagem corporal), e não os motivos ou o próprio fenômeno, tal como eles estiverem en train de (o poder da imagem do corpo amputado sob minha relação com o mundo, por exemplo).

Se for assim, não poderíamos nos basear nem numa explicação fisiológica, nem numa explicação psicológica, nem mesmo numa tese mista. Como pensarmos então este problema do membro fantasma?

Podemos identificar ao menos duas questões fundamentais em Lhermitte para Merleau-Ponty:

1. ele afirma que há uma correlação entre a imagem corporal e a própria percepção que temos do mundo exterior, o que é muito interessante, porque assim ele nos diz de um certo tipo de síntese (LHERMITTE, 1998, pp. 30-31) que determinaria nosso “esquema corporal” (assim também no caso do amputado, que determinaria uma síntese corporal de acordo com sua imagem corporal); 
2. a tentativa de Lhermitte (mas também de Schilder) aponta para um novo modo de pensar: para aquela perspectiva do ser-no-mundo, que Merleau-Ponty insiste em nos levar, pois o fenômeno do membro fantasma demonstra-nos antes de mais nada uma “resistência corporal”, ao mesmo tempo em que nos mostra uma “aderência” de nosso corpo à nossa experiência familiar com o mundo. Afinal, se nossas experiências restam abertas ao mundo, se há uma significação “prática” em nossas ações, a perda de um membro não poderá se “suprimir” totalmente, porque este membro tende a agir em sua familiaridade: "no momento mesmo em que meu mundo costumeiro suscita em mim intenções habituais, eu não posso mais, se sou amputado, me juntar efetivamente a ele e os objetos manejáveis, justamente enquanto se apresentam como manejáveis, interrogam uma mão que eu não mais tenho” (PhP, p. 97).

Entendamos: há por um lado uma síntese corporal que determina meu esquema corporal, minha relação com o mundo, com o outro e comigo mesmo: “este fantasma, esta imagem animada da perna, é a expressão do esquema corporal”, como diz Paul Schilder (1950, p. 13). Mas há também uma resistência corporal, habitual, que insiste em fazer parte da familiaridade do amputado com o mundo. Afinal, se o homem assume em seu cotidiano um “corpo habitual”, para que cada gesto, a cada instante, não seja para ele um enigma ou mesmo um obstáculo, então esta estrutura habitual estaria como que incrustada na corporalidade de um sujeito amputado (isto não diz de uma “fatalidade”, mas de uma necessidade de um comportamento estável do organismo (PhP, p. 109)).

Isso nos leva a pensar num certo tipo de vínculo corporal de recusa, que envolve um problema maior: o corpo habitual parece sugerir uma constituição do esquema corporal segundo um comportamento direto com o mundo, não representacional, que recusa se atualizar segundo o corpo amputado atual. Tratar-se-ia assim de afirmar que o esquema 
corporal envolve todas as atividades possíveis, e não apenas um esquema do estado do corpo (Sorb, p. 59). Mas isto ainda não explica o porquê desta recusa.

Uma dica nós podemos tomar do Dr. Hesnard (1960, p. 320), ao comentar isto: “toda doença mental é uma doença existencial, na qual o corpo próprio, quer dizer, a consciênciacorporalidade não realiza mais sua tarefa vital, que consiste em aplicar uma dialética do homem em debate com o meio, a encarnar as intenções que visam o mundo (...)”. Ou seja, o amputado tem dois caminhos: por um lado, ele atualiza, assume esta postura do corpo com o mundo; ou então, ele a recusa, com o preço de se arraigar a uma estrutura de ação determinada, como o doente, perdendo a virtualidade da ação.

Trata-se então de algo muito próximo do que descrevíamos sobre a diferença entre o normal e o patológico. No sujeito normal, como afirma Waelhens (1968, p. 109), “o corpo é o conjunto de condições concretas sob as quais um projeto existencial se atualiza e se torna, atualizando, propriamente meu”. Ou ainda (p. 110): “cada um visa constantemente no mundo de sua experiência uma zona de operações possíveis que definem sua adaptação e, inseparável dela, seu corpo tal como seu passado lhe forneceu”. Noutro caso, ele (p. 114) “(...) recusa reconhecer esta restrição [a perda de um membro] e, tendo que optar entre a perda de si como liberdade de fazer um mundo à sua medida e a perda do mundo próximo [habitual, antes da perda do membro] onde ele se escolheu e se exerceu até o presente, prefere negar aquela liberdade e salvaguardar seu mundo próximo (....)”. Ora, se o amputado escolhe esta segunda alternativa, tratar-se-ia então de uma fixação e, por isso, de um recalque, algo que poderíamos partilhar com a psicanálise, segundo Merleau-Ponty, pois o amputado agiria conforme um certo privilégio de ação que estaria recalcada numa temporalidade própria:

pois o recalque de que fala a psicanálise consiste naquilo em que o sujeito engaja numa certa via relação amorosa, carreira, obra -, e que ele encontra nesta via uma barreira e, não tendo força nem para transpor este obstáculo, nem de renunciar o empreendimento, ele fica bloqueado nesta tentativa e emprega indefinidamente suas forças a renová-la em espírito (PhP, p. 98). 
O amputado se fixaria num esquema corporal familiar, recusando sua situação atual ao não tematizá-la, ou agindo de tal modo como se nosso comportamento estivesse desenhado de uma vez por todas em sua generalidade (PhP, p. 103). O membro-fantasma seria assim uma experiência recalcada (que já Lhermitte (1998, p. 108) reconhecia modificar o esquema corporal):

o braço fantasma é como uma experiência recalcada, uma presença antiga que não se torna passada. As lembranças que se evocam diante de um amputado induzem o membro fantasma não como uma imagem que no associacionismo chama outra imagem, mas toda lembrança busca o tempo perdido e nos convida a retomar a situação evocada (PhP, p. 101).

Esta questão é interessante porque nos leva a pensar como a experiência recalcada pode determinar nossa relação com o mundo, principalmente se acompanharmos o filósofo, ao afirmar que o membro fantasma é uma quase-presença (PhP, p. 101) deste membro (e não uma lembrança ou uma representação deste membro). Não se tratará então de uma “representação” de um membro, mas da “presença ambivalente” do membro ou de uma “memória corporal” (Sorb, p. 362) deste membro fantasma que Merleau-Ponty encontra “latente”, curiosamente, no pensamento proustiano:

o amputado sente sua perna como eu posso sentir vivamente a existência de um amigo que não está, todavia, sob meus olhos; ele não a perdeu porque continua a contar com ela, como Proust pode bem constatar a morte de sua avó sem a perder ainda enquanto a conserva no horizonte de sua vida. O braço fantasma não é a representação de braço, mas a presença ambivalente de um braço. A recusa da mutilação no caso do membro fantasma ou a recusa da deficiência na anosognose não são decisões deliberadas, não se passa no nível da consciência tética que toma posição explícita depois de ter considerado diferentes possíveis. A vontade de ter um corpo são ou a recusa do corpo doente não são formulados por eles mesmos, a experiência do braço amputado como presença ou do braço doente como ausente não são da ordem do ‘eu penso que...' (PhP, p. 96).

Lhermitte estaria correto, portanto, ao afirmar que não haveria sentido em desvincular o “psíquico” e o “fisiológico”, mas não teria percebido que esta imbricação está na relação de existência, e por isso mesmo na existência temporal: trata-se então de uma memória corporal. Lembremos que o próprio termo quase-presença equivale à retenção de Husserl (1994, 
à medida que prossegue o processo de recordação iterativa, este horizonte abre-se de novas maneiras e torna-se mais vivo, mais rico. E, com isto, este horizonte preenche-se com acontecimentos interativamente recordados sempre novos. Os que antes eram apenas pré-indicados são agora quasepresencializados, quase no modo do presente atualizador.

Isso significa que o amputado é um sujeito doente porque se fixa numa determinada conduta, não estando aberto a um campo de possibilidades diante do mundo. Entretanto, esta fixação é uma fixação temporal: ele se fixa num passado que sempre retoma como sendo seu presente atual. O membro não está ali, mas o sujeito age como se ele estivesse ali (ele age de um modo habitual). Por isso o membro é quase-presente. Ou seja, “quase”, porque algo escapa à presença: não posso ver meu membro perdido, mas “vivo” sua presença. É por isso que o recalque seria, no fundo, um advento que nos faria compreender nossa condição de seres com estrutura temporal e existencial. Merleau-Ponty é preciso: "como advento do impessoal [por se basear numa sedimentação corporal], o recalque é um fenômeno universal, ele faz compreender nossa condição de sermos encarnados ligando-o à estrutura temporal de ser-no-mundo” ( $\mathrm{PhP}$, p. 99), mesmo que esta temporalidade tenha o privilégio de uma fixação. Moutinho (2006, pp. 126-127), comentando esta passagem, também é preciso: “a ambigüidade do corpo (corpo atual e corpo habitual) deverá ser compreendida pela ambigüidade do tempo, pois o passado não deverá ser jamais completamente transcendido, ele deve permanecer, de algum modo, presente”.

Como vemos, é se apoiando na "generalidade do corpo" que Merleau-Ponty nos descreve como agimos enquanto uma unidade corporal, mesmo no caso do membro fantasma: é a partir de um corpo habitual que o sujeito age. É a temporalidade do sujeito que está em jogo: a tomada de consciência do corpo seria assim tributária de um corpo habital ainda presente na ação.

Entretanto, Lhermitte, por exemplo, nos diz que a consciência desta unidade corporal é uma consciência de uma imagem corporal que cada um tem de si: “(...) é graças a esta imagem de nosso corpo que é possível a nós sentir, perceber, enfim, desenvolver nossa ação 
sobre nós mesmos e sobre o mundo que nos rodeia” (LHERMITTE, 1998, p. 15). Como vimos, Merleau-Ponty não precisa se apoiar diretamente na imaginação para explicar o advento do membro fantasma, mesmo se baseando nos estudos do psicólogo. Do mesmo modo, no esquema corporal: não é porque tenho uma imagem de minha unidade que sei que passo por esta brecha, mas porque "eu sei” que meu corpo passa por ali: "a consciência do corpo invade o corpo" (PhP, p. 90). É o "estatuto do saber" que é modificado, como já nos advertia Lefort. É o corpo que compreende: não é preciso uma imagem corporal para o desempenho corporal. Há uma síntese “presuntiva” do corpo que está em operação neste desempenho. Entendamos o porquê disto.

\section{3) Porque não dizer de uma imagem corporal?}

Se ficarmos atentos à Phénoménologie de la Perception, veremos que são poucas as vezes que Merleau-Ponty se refere ao problema da imaginação. Num destes poucos momentos, ele diz: “(...) perceber no sentido pleno da palavra, que se opõe a imaginar, não é julgar, é apreender um sentido imanente ao sensível antes de todo julgamento” (PhP, p.44). A insistência em dizer que perceber não é julgar, é provável que venha de uma crítica a Alain (1941, pp. 56-59; Sorb, p. 225). Quanto à afirmação de que perceber se opõe a imaginar, tratase de insistir no fato de que é unicamente na percepção que o objeto está presente: o imaginário se faria a partir de “detritos” do real (PhP, p. 413) (a imagem jamais é algo observável). Quer dizer, quando imagino esta tela, imagino-a como um todo, diferentemente da percepção que tenho dela, que se dá de modo perfilar, fragmentário, assim como está presente a mim. 
Noutra passagem, ele destaca como, no real, o sentido está imbricado na existência da coisa, diferentemente da imaginação, e complementa: “o imaginário é sem profundidade, não responde aos nossos esforços para variar de pontos de vista, não se presta à nossa observação [Sartre]” (PhP,. P. 374). Isso porque a imagem se dá como um todo e não se presta a uma exploração infinita.

É exatamente por reconhecer esta característica da consciência imaginante que podemos estranhar a análise merleau-pontyana: se a imagem é um todo, algo que se dá sem a fragmentação do objeto percebido, então nada mais natural pensarmos que é a imagem corporal que guiaria o sujeito na relação com o mundo. Lembremos que o sujeito amputado, por exemplo, age como se houvesse o membro perdido: o sujeito amputado não vê o membro que (aliás) não existe mais. Ele percebe uma “quase-presença”, segundo Merleau-Ponty. Mas se não há aqui uma percepção deste membro assim como eu vejo esta tela em minha frente (neste perfil de onde me situo), nada seria mais natural do que dizermos que o sujeito amputado tem uma "consciência imaginativa” de sua totalidade (enquanto não amputado, enquanto uma totalidade - uma imagem).

Sendo assim, poderíamos dizer: eu ajo como se, mas se eu olhar para onde o membro já não existe mais, não poderia me furtar em afirmar que ele não está presente assim como é presente para mim esta tela ou qualquer outro membro que vejo. Nada seria mais natural, a meu ver, que acompanharmos Lhermitte (1998, p. 15): “(...) é graças a esta imagem de nosso corpo que é possível a nós sentir, perceber, enfim, de desenvolver nossa ação sobre nós mesmos e sobre o mundo que nos rodeia”. Ou ainda Schilder (1950, p. 201): “nós vivemos constantemente com o saber do nosso corpo. A imagem corporal é uma das experiências básicas de todos na vida. É uma dos pontos fundamentais da experiência vivida”. Quer dizer, é porque tenho consciência de mim como uma totalidade, como uma imagem, que poderia saber que passo debaixo daquele galho. 
Entretanto, como vimos na Phénoménologie de la Perception, não é assim que ocorre: eu sei que passo debaixo daquele galho devido um saber corporal do volume do meu corpo — há uma síntese perceptiva presuntiva do meu corpo. Ou ainda no caso do membro fantasma: trata-se de um caso da "memória corporal” (lembremos que a temporalidade é de um sujeito corporal). Aliás, ele diz de uma “quase-presença”, mas que é solidária àquele saber corporal, e não à consciência imaginativa. Na verdade, Merleau-Ponty descreve toda nossa relação com o mundo a partir da consciência perceptiva. A imaginação nos levaria a um outro problema, aos seus olhos, como nos diz no curso sobre a Structure et Conflits de la Conscience Enfantine: “a consciência nos libera do presente pelo imaginário, é um poder de irrealizar-se fora das coisas” (Sorb, p. 229). Dizendo de um outro modo, seria apenas na descrição da consciência perceptiva que se poderia satisfazer a exigência de uma descrição direta da experiência. O exemplo do mundo infantil é privilegiado neste caso: “para a criança, a percepção é uma conduta pela qual ela empenha-se num verdaderio comércio com as coisas” (Sorb, p. 224).

Na verdade, o problema da imaginação era algo que Sartre (1948, p. 163) colocava em pauta ao propor que na imaginação os objetos são “irreais”. A imaginação teria como função transcender ou aniquilar a realidade do mundo percebido. Trata-se de uma intencionalidade que teria a capacidade de aniquilar o mundo, isso porque “o real e o imaginário, por essência, não podem coexistir. Trata-se de dois tipos de objetos, de sentimentos e de condutas inteiramentes irredutíveis” (SARTRE, 1948, p. 188).

Sabemos que desde 1936, em sua primeira obra, o objetivo de Sartre era mostrar como a imaginação é um certo tipo de consciência: “a imagem é um certo tipo de consciência. A imagem é um ato e não uma coisa. A imagem é consciência de alguma coisa” (SARTRE, 1989, p. 120). Para chegar nesta conclusão, o filósofo seguiu um caminho crítico aos sistemas metafísicos e ao esforço dos psicólogos para encontrar um método positivo de abordar a 
imagem. Assim, ele nos mostrava como continuava vivo o associacionismo e como a fenomenologia, principalmente aquela apresentada em Ideen... I, era não só totalmente diferente das ciências psicológicas, como apontava um novo modo de pensar: ela exigia que se expulsasse todos os "habitantes” da consciência, "libertando o mundo psíquico de um grande peso” (SARTRE, 1989, p.110). Neste caminho, Sartre pretendia buscar um novo sentido de “imagem” que não fosse comparável à percepção (como uma percepção fraca, por exemplo).

Já em 1940, Sartre (1949, pp. 14-26) descrevia a imagem sob quatro características:

1. como uma consciência: imaginar é ter um certo tipo de consciência;

2. como um fenômeno de "quase-observação": há um saber imediato da imagem, pois como ela se dá como um todo, como aquilo que tenho consciência dela, eu sei o que imagino sem apreender nada dela (porque eu constituo a imagem). Por isso uma quase-observação: uma observação que não apreende nada;

3. a consciência imaginativa põe seu objeto como um nada: a imagem se põe como um certo nada, porque o objeto intencional imaginado tem uma posição de ausência, de inexistente;

4. como espontaneidade: porque a consciência imaginativa produz e conserva seu objeto em imagem;

Sem irmos adiante na tese sartreana e nas suas conseqüências, o importante é destacarmos como o problema da imaginação nos leva a pensar numa relação diferente com o mundo, descrita em termos da consciência perceptiva. Como se pode perceber, a consciência imaginativa, descrita por Sartre, nos leva a pensar numa certa “negação” do mundo percebido. Como diz Merleau-Ponty: “é preciso que a consciência deixe de viver no mundo dos objetos, que ela 'se ponha' no espetáculo que a ela se oferece” (Sorb, p. 230). 
Dentre os inúmeros distanciamentos entre os dois filósofos, gostaria de ressaltar como Merleau-Ponty não poderia seguir este caminho para ser fiel à sua fenomenologia. É simples entendermos o porquê: a descrição do ser-no-mundo, aos seus olhos, deveria seguir uma descrição de uma relação direta com o mundo: percebendo-o, porque há somente um "ato humano que de um só golpe atravessa todas as dúvidas possíveis para se instalar em plena verdade: este ato é a percepção, no sentido amplo de conhecimento de existências” (PhP, p. 50). É preciso assim ter uma acesso direto ao real. A imaginação, por outro lado, nos leva a uma pseudo-realidade: “não há Pedro em imagem e Pedro na realidade, só há um Pedro, aquele que está lá e que eu me esforço para fazer surgir aqui. Imaginar é encaminhar-se para o objeto real a fim de fazê-lo surgir aqui. Há uma pseudo-realização do objeto imaginário, há produção de um analogon do objeto ausente” (Sorb, pp. 225-226).

É certo assim que Merleau-Ponty dá um certo privilégio à consciência perceptiva, mas isto não significa que não seja possível imaginar, significa que “toda consciência é, em algum grau, consciência perceptiva” (PhP, p. 452): “a imaginação visa sempre o objeto percebido” (Sorb, p. 225). Aliás, aos seus olhos, imaginar é possível porque o mundo se presta a uma “tolerância” (PhP, p. 395). Na verdade, Merleu-Ponty não aceita uma distinção tão brusca entre o imaginário e o real, como salientava Sartre (Sorb, p. 230). O caso da alucinação é privilegiado neste sentido. Vejamos para onde isso aponta.

\section{4) Ilusão e percepção — uma fé no mundo}

Sob o ponto de vista da alucinação, ainda aqui, Merleau-Ponty insiste em nos dizer de uma diferença entre o normal e o patológico, destacando que a alucinação só é possível 
devido àquele “poder corporal”: a ilusão é possível, porque o corpo é capaz de evocar uma “pseudo-presença” (PhP, p. 392) ou uma uma “quase-realidade” (PhP, p. 385).

Isto se deve ao fato do corpo evocar um mundo de modo “deformado": “ter alucinações e, em geral, imaginar é aproveitar essa tolerência do mundo antepredicativo (...)” (PhP, p. 395). Na alucinação, o sujeito "substitui” o mundo real, perceptivo, por uma "quaserealidade” (PhP, p. 385): “a imagem e a alucinação comportam uma impostura, dando-se como quase-visões” (Sorb, p. 225).

Diferentemente, um sujeito normal compreende o sentido que está inscrito no mundo e não lhe atribui nada que o próprio mundo não suscite:

tenho consciência de perceber um ambiente que não 'tolera' nada além daquilo que está escrito ou indicado em minha percepção, comunico-me no presente com uma plenitude intransponível. O alucinado não crê tanto: o fenômeno alucinatório não faz parte do mundo, quer dizer, ele não é acessivvel, não existe caminho definido que conduza dele a todas as outras experiências do sujeito alucinado ou à experiência dos sujeitos sãos (PhP, p. 390).

Mas o mundo alucinado não é, como o mundo real, atulhado de pequenas percepções que sustentam sua existência (PhP, p. 391). O sujeito evoca um mundo “desarticulado”, que não se presta a uma exploração infinita ou que motive à ação. Ele evoca sentidos que não estão no mundo, que não estão no campo perceptivo, e sim “diante” dele. Trata-se assim de um distúrbio da própria relação do sujeito com o mundo.

Diferentemente do caso de Schneider (que se fixa num mundo), o alucinado, ao evocar um mundo que não se apresenta realmente, se distancia da inserção do seu corpo no mundo: o sistema alucinatório usurpa a força expressiva do mundo (PhP, p. 394). É por isso que, para Merleau-Ponty, “toda alucinação é, em primeiro lugar, alucinação do corpo próprio” (PhP, p. 391), porque o sujeito evoca um mundo a partir das suas próprias sedimentações:

existem alucinações porque nós temos, através do corpo fenomenal, uma relação constante com um ambiente que ele se projeta e porque, separado do ambiente efetivo, o corpo permanece capaz de evocar, por suas próprias montagens, uma pseudo presença desse ambiente. Nessa medida, a coisa alucinatória nunca é vista nem visível (PhP, p. 392). 
Deste modo, como no caso da imaginação, que se faria a partir de “detritos” do real (PhP, p. 413), o alucinado usa do campo sensorial e de sua relação com o mundo para fabricar, “(...) com os fragmentos deste mundo, um ambiente factício conforme à intenção total de seu ser” (PhP, p. 393). Vale aqui o mesmo que na imaginação: “é preciso que a consciência deixe de viver no mundo dos objetos, que ela 'se ponha' no espetáculo que a ela se oferece” (Sorb, p. 230).

É este espetáculo, este mundo “fabricado”, o que vale para o sujeito alucinado como real (PhP, p. 394). Ele se benificia de sua crença no mundo e cria para si um mundo “privado”. Percebamos que é pelo próprio caráter da alucinação que isso ocorre: “a imagem adere à consciência do alucinado ou do sonhador justamente porque ela não é observável. A imagem me dá a idéia de uma comunicação direta, absoluta, ela se oferece de uma só vez e tem nisso uma espécie de poder convincente” (Sorb, p. 229). Mas percebamos também que é a própria "fé" no mundo que possibilita a alucinação, e é pela sua "tolerância" que ela surge.

Mas o sujeito normal também crê no mundo: “perceber é empenhar de um só golpe todo um futuro de experiências num presente que, a rigor, não o garante jamais; é crer num mundo" (PhP, p. 344). Eu creio no mundo, eu tenho uma “fé originária” (PhP, p. 371), porque estou totalmente em direção a ele, e minha existência já está polarizada (PhP, pp. 371-372). Há uma adesão cega ao mundo (PhP, p. 294): “a percepção não espera as provas para aderir ao objeto, ela é anterior à observação atenta” (Sorb, p. 230).

É certo que em alguns casos o sujeito que alucina é capaz de diferenciar uma percepção verdadeira (induzida por um experimentador) de sua alucinação. Mas há casos mais complexos que o sujeito não o faz. Conseqüentemente, no limite, isso nos indica que não podemos distinguir uma percepção verdadeira de uma alucinação, senão afirmando que há uma diferença entre um “mundo privado” e um “mundo real”. Sendo assim, seria somente na 
intersubjetividade que eu saberia realmente se estou alucinando ou se estaria percebendo um “mundo partilhado”.

Mas entre eu e outrem, quem está vivendo num mundo de ilusão? Uma "verificação” um pouco difícil de se fazer, uma vez que não posso ter acesso ao "mundo privado do outro". Merelau-Ponty argumenta que isto não significa que não posso “compreender” o mundo de outrem. Ora, do mesmo modo que tenho acesso a algo que não está presente senão de modo “deformado”, o meu passado, posso também compreender, de algum modo, o outro mundo privado pelo meu, levando em conta esta deformação (PhP, p. 389).

Entretanto, este argumento não exclui o fato de não podermos viver o que outrem vive, mesmo que nós vivamos num “mundo partilhado”. Não há como negar que há um certo tipo de "solisismo" que não pode ser ultrapassado ( $\mathrm{PhP}$, p. 411). "Em Deus eu posso ter consciência de outrem como de mim mesmo, amar outrem como a mim mesmo” (PhP, p. 411).

Posso assim afirmar que tenho consciência da minha unidade corporal, da unidade corporal do outro, que percebo seu comportamento, que compreendo seu estilo de ser, mas não posso negar que há um mundo inacessível a mim: aquilo que o outro vive.

Mais interessante que isso, talvez, seja o fato da própria existência ou da possibilidade da alucinação me indicar que a consciência perceptiva não tem plena posse de si: cada percepção pode ser “barrada”, pode ser reconhecida como uma ilusão, mas somente dando lugar a uma outra percepção (PhP, p. 396). Para Merleau-Ponty, há uma crença no mundo de tal monta que não devemos nos perguntar se percebemos verdadeiramente ou não, mas, antes, “(...) deve-se dizer o contrário: o mundo é isso que nós percebemos” (PhP, p. xi). Aliás, era isto que a Gestalttheorie nos apontava:

esta distinção entre dois tipos de percepção, uma normal e outra ilusória, desaparece como uma distinção psicológica logo que nós nos tornemos completamente cientes da falácia que isto implica, por mais que isto possa restar numa distinção epistemológica. Para cada coisa nós devemos perguntar a 
mesma coisa: ‘porque as coisas parecem como são?’ pareçam elas 'corretas’ ou 'erradas' (KOFFKA, 1955, p. 79).

O que interessa a Merleau-Ponty é o fato de estarmos engajados no mundo e, por isso mesmo, expostos às ilusões: “(...) é preciso que a ‘síntese’ perceptiva seja inacabada, ela só pode oferecer-me um 'real’ expondo-se ao risco do erro’ (....)” (PhP, p. 432). Mas a ilusão ou o erro só se dão a partir da experiência perceptiva, e só são suscetíveis de serem apontados como tal por serem também suscetíveis de serem reconhececidos assim. Na própria experiência, eu jamais posso saber disso: eu só me corrigo no próprio desenrolar da experiência. Eis um bom exemplo do filósofo:

\begin{abstract}
se caminho em um praia em direção a um barco encalhado e a chaminé ou o mastro se confundem com a floresta que circunda a duna, haverá um momento em que estas partes se juntarão vivamente ao barco e se soldarão a ele. À medida que eu me aproximava, não percebi semelhanças ou proximidades que enfim teriam reunido a superestrutura do barco em um desenho contínuo. Eu apenas senti que o aspecto do objeto ia mudar, que nesta tensão algo era iminente assim como a tempestade é iminente nas nuvens. Repentinamente, o espetáculo se reorganizou satisfazendo minha espectativa imprecisa. (...) 'Como não vi que estes pedaços de madeira faziam corpo com o barco? No entanto, eles tinham a mesma cor que ele, ajustavam-se bem à sua superestrutura'. Mas essas razões de bem perceber não eram dadas como razões antes da percepção correta ( $\mathrm{PhP}, \mathrm{pp}$. 24-25).
\end{abstract}

Há uma ambigüidade no mundo, uma indeterminação, que permite a ilusão: ela é o berço de todas as experiências, um reservatório inesgotável (PhP, p. 396). Ele já se apresenta sob uma organização, ele é isto que percebo, sendo uma percepção correta ou não.

\title{
5) A consciência de si
}

Sob a “inadequação” da percepção, que eu já apontava desde o primeiro capítulo, deve-se acrescentar que a percepção interior é também “inadequada”, “porque eu não sou um objeto que se possa perceber, porque eu faço minha realidade e só me encontro no ato” (PhP, p. 438). Ou ainda: “pode-se dizer da percepção interior o que nós dissemos da percepção exterior: que ela envolve o infinito, que ela é uma síntese não acabada e que se afirma, 
embora seja inacabada” (PhP, p. 439). Por exemplo: eu só percebo que o amor que sinto é falso se me der conta, no futuro, que aquilo que sinto é outra coisa que o amor. O que permite isso, para Merleau-Ponty, é o reconhecimento que, na vida perceptiva, “o tempo é a medida”: no próprio desenrolar eu reforço ou não um sentido que apreendo. “Nós temos a experiência de um Eu, não no sentido de uma subjetividade absoluta, mas indivisivelmente desfeitos e refeitos no curso do tempo” (PhP, p. 254). É por isso que é possível o “membro fantasma”, pois o sujeito se fixa num “corpo habitual” ao se fixar num passado que, mesmo “deformado”, permanece presente ao sujeito.

Mas o fato de haver este “desenrolar” me evidencia um contato direto de um certo tipo de consciência de si em exercício (PhP, p. 426). Ora, se o sujeito não pudesse ter uma consciência de si, seria reduzido à condição de uma coisa ou de uma força que produz seus efeitos no exterior sem ser capaz de sabê-lo, segundo Merleau-Ponty (PhP, p. 426). Não se trata de um simples fato isto: eu me reconheço imediatamente a todo o momento, pois eu só posso ter consciência do mundo se tenho consciência de mim, senão me dispersaria e não teria consciência de nada (PhP, p. 274): “é preciso que o ato pelo qual tenho consciência de algo seja ele mesmo apreendido no instante em que se realiza, sem o que ele se romperia” ( $\mathrm{PhP}$, p. 426).

A conclusão desta questão é fundamental ao filósofo:

precisamos recusar à consciência perceptiva a plena posse de si e a imanência que excluiria toda ilusão. Se as alucinações devem poder ser possíveis, é preciso que em algum momento a consciência deixe de saber aquilo que faz, sem o que ela teria consciência de constituir uma ilusão, não aderiria a esta, então não haveria mais ilusão (...). É preciso apenas que a coincidência de mim comigo (...) nunca seja uma coincidência real, e seja, somente, uma coincidência intencional e presuntiva. De fato, entre mim mesmo que acabo de pensar isto e eu que penso que o pensei, já se interpõe uma espessura de duração e sempre posso duvidar se este pensamento já passado era exatamente tal como eu vejo presentemente. Como, por outro lado, não tenho outro testemunho sobre meu passado senão estes testemunhos presentes, e como todavia tenho a idéia de um passado, não tenho razão em opor o irrefletido, como um incognoscível, à reflexão que faço incidir nele (PhP, pp. 396-397).

Isso evidência uma consciência de si que não se possui totalmente, mas que se freqüenta a todo o momento. Barbaras (1998, p. 171), por exemplo, nos diz que, "não somente 
a consciência de si é um momento da percepção, mas ela é ela-mesma uma percepção, pois eu só sou dado a mim mesmo de modo parcial e não-total”. Quer dizer, há algo que escapa da plena coincidência da consciência de si a si mesma, porque ela sempre está engajada numa espessura que perpassa a todo o momento. Há algo que escorrega nesta identidade. Exatamente pela consciência não poder se afirmar enquanto um pleno absoluto, ela está sempre num ato violento de passagem: daquilo que se é àquilo que vem a ser (PhP, p. 438). É esta passagem violenta, que vivenciamos a todo o momento, que torna meu engajamento ao mundo um ato que transcende este aqui-agora. Há uma certa ultrapassagem de si num pacto que não pode ser selado num único ato, mas que perpassa minha existência numa temporalidade que jamais esgota a transparência de si mesma. "Para Merleau-Ponty, (...) toda consciência é transgressão dela mesma” (WAELHENS, 1961, pp. 384-385).

Segundo Merleau-Ponty, é porque estamos sempre en train de que a consciência só pode se afirmar enquanto um fazer, enquanto algo que, em ato, se realiza a todo o momento sem se esgotar, que só se apreende escorregando (PhP, p. 462). “Graças ao tempo, tenho um encaixe e uma retomada das experiências anteriores, mas em nenhuma parte uma posse absoluta de mim por mim, já que o vazio do futuro se preenche sempre com um novo presente” (PhP, p. 278). Esta é uma passagem importante ao filósofo, pois lhe levava a reafirmar "o gerúndio" (en train de) como a afirmação fundamental da existência: sei que amo, amando; sei que creio, crendo (PhP, p. 433).

Tratar-se-ia assim, no fundo, de inverter o cogito cartesiano: é preciso que se coloque um cogito que não necessite de uma expressão verbal para saber de si: “não é porque eu penso ser que estou certo de existir, mas, ao contrário, a certeza que tenho do meu pensamento deriva de sua existência efetiva” (PhP, p. 438). Ou antes, deveríamos dizer que existo, vivo, e por isso penso. Isto é muito importante, porque indica uma subjetividade muito distante da 
subjetividade de tradição cartesiana: há um Eu, mas que não é transparente a si, que é vivido (ambíguo) antes que pensado.

Neste sentido, podemos compreender como, diferentemente de Descartes, este cogito não poderia ser algo que devesse se afirmar a todo o momento, como o próprio Descartes (1950, p. 88) afirma: “(...) esta proposição: eu sou, eu existo é necessariamente verdadeira toda vez que eu a pronuncie ou que a concebo em meu espírito”. Para Merleau-Ponty, este cogito cartesiano é verbal e está no domínio do “eu penso que”, exprimindo apenas um pensamento pontual que não atinge o cogito que tenho realmente de mim (e mesmo de Descartes ao formulá-lo). Como nos diz Muller (2001, p. 292): “mesmo que Descartes chame minha atenção para o Cogito que tenho de mim, o Cogito lido e compreendido não abrange, por ocasião da leitura e compreensão do texto, o contato pré-reflexivo de mim comigo mesmo”.

Esta experiência vivida que perpassa meu presente e que transgride a si mesma nos leva a pensar que todo ato pressuporia um "fundo silencioso” ou uma "consciência silenciosa” (PhP, p. 463): uma consciência de si (mesmo que inacabada) que atravessa e está presente a todo o momento, mas que nem por isso constitui o mundo. É preciso pressupor uma unidade, um fundo silencioso, mesmo que esta unidade não seja um absoluto ou algo acabado: a subjetividade, ou a temporalidade, seria como uma experiência de uma unidade (aberta) na dispersão (WAELHENS, 1968, p. 292).

É por isso que a temporalidade não pode ser uma sucessão de “agoras”, senão deverse-ia afirmar a si a todo o momento. É preciso que o passado seja de algum modo presente, assim como o futuro. Não por menos, a subjetividade se confunde com a coesão de uma vida temporal (PhP, p. 483), mesmo que transgrida a si a todo o momento. Trata-se de um fluxo inapreensível mas que se sabe a si mesmo porque é um fenômeno que se 
tempo efetivo ou que ele se espalhe, mas ainda, um tempo que se saiba, pois a explosão ou a deiscência do presente para um futuro é o arquétipo da relação de si a si e desenha uma interioridade ou uma ipseidade (PhP, p. 487).

É por isso que, para Merleau-Ponty, “é preciso compreender o tempo como sujeito e o sujeito como tempo” (PhP, p. 483). O que isso quer dizer? Que as dimensões temporais exprimem uma só dissolução, porque elas se “recobrem mutuamente" num campo de presença que sabe a si mesmo. E é esta presença de si a si mesmo que é sinônimo da própria existência para o filósofo (PhP, p. 462).

Mas este saber de si, que se evidencia nesta presença de si, certamente não é da ordem do "eu penso". Trata-se de um saber da mesma ordem do cogito: um saber tácito, algo muito próximo da consciência não-tética sartreana, porque exige do mesmo modo uma experiência pré-reflexiva, impessoal e anônima, como ele mesmo nos esclarece nesta nota de janeiro de 1959:

o cogito de Descartes (a reflexão) é uma operação sobre significações, enunciando de relações entre elas (e as próprias significações sedimentadas nos atos de expressão). Pressupõe, portanto, um contato préreflexivo de si consigo mesmo (consciência não-tética (de) si, Sartre) ou um cogito tácito (ser junto a si) - eis como raciocinei na Ph.P. [Phénoménologie de la Perception] (VI, p. 222).

Lembremos que, em La Transcendende de l'ego, Sartre coloca em pauta uma questão fundamental em sua obra: a posição do Eu na consciência. Na verdade, o filósofo nos apresenta uma consciência desprovida de um Eu como síntese de todos os estados de consciência. Isto é bastante sugestivo: trata-se de afirmar que este Eu é um objeto da consciência, e não sujeito (como rogava a tradição cartesiana).

A conseqüência disso é importante: haveria assim dois tipos de consciência, uma reflexiva, outra irrefletida. No primeiro caso, tratar-se-ia de uma consciência que seria solidária a um “eu penso”. Já esta última seria como o primeiro grau da consciência, definida como intencionalidade (SARTRE, 1947, p. 33). Neste sentido, o Eu seria algo que se mostraria sob um fundo pré-reflexivo, tendo assim a possibilidade de se afirmar um campo pré-pessoal ou impessoal, porque “a consciência não-reflexiva torna possível a reflexão: 
existe um cogito pré-reflexivo que é a condição do cogito cartesiano” (SARTRE, 2006, p. 19). É esta consciência não-tética (de) si que tornaria possível algo como um “eu”. Ela seria algo da ordem da existência, impessoal, tendo como caráter essencial a determinação de si por si, como plenitude de existência. Isso significa que a consciência teria consciência de si, limitando a si própria.“Consciência é consciência de ponta a ponta” (SARTRE, 2006, p. 21).

É por aí que caminha Merleau-Ponty, como ele mesmo afirmou. Haveria um cogito que sustentaria o cogito cartesiano. Algo da ordem da existência, do impessoal, que tornaria possível a existência de um Eu. A estratégia de Merleau-Ponty é bem próxima de Sartre: seria preciso encontrar “um reduto de não-ser, um Si [Soi]” (PhP, p. 458). Por quê?

A resposta do filósofo é esta: se há consciência, é necessário que atrás de nossos pensamentos particulares haja um Si, uma região de generalidade (PhP, p. 458). Seria preciso afirmar um lugar de generalidade no sujeito. Não aquela generalidade corporal que dizíamos páginas antes, que se dava numa indeterminação de toda percepção (on), mas uma generalidade que lhe fundamentaria. Trata-se deste fundo silencioso, este Si, que está atrás de todo pensamento. O objetivo aqui do filósofo é mostrar como nenhum ato particular (a percepção, por exemplo) esgota a totalidade da existência. Há sempre um saber inacabado que pressupõe um horizonte possível e incerto. É a certeza deste inacabamento, desta nãocoincidência consigo, que nos leva a afirmar uma generalidade do sujeito sempre pressuposta em cada ato que realiza.

Mas falta-nos ainda pensar como, paradoxalmente, é a partir de uma pontuação, de um ato, que é possível se ter consciência de si: “a verdade do solipsismo está aqui. Toda experiência sempre me aparecerá como uma particularidade que não esgota a generalidade de meu ser, e tenho sempre, como dizia Malebranche, movimento para ir mais longe” (PhP, p. 413). 


\title{
6) O corpo com posse do tempo
}

É certo que, tratando-se de uma subjetividade, é preciso que haja algo que unifique todas as particularidades. Quer dizer, seria impossível dizermos de uma história pessoal se não presumíssemos que há algo que unificasse todos nossos atos particulares. É neste sentido que Merleau-Ponty inscreve o cogito tácito: como uma generalidade da subjetividade que integra a experiência do sujeito. Entretanto, só é possível a este sujeito ter consciência de si quando realiza um ato: “assim como a unidade do mundo, a unidade do Eu é antes invocada do que experimentada a cada vez que efetuo uma percepção, a cada vez que obtenho uma evidência (...)” (PhP, p. 465).

Isto significa que Merleau-Ponty une o ser no mundo com o ser para si. Eis o fato: ter experiência é comunicar um sujeito finito, mas que sabe de si como um ser opaco, de onde se emerge e onde permanece engajado ( $\mathrm{PhP}, \mathrm{p}$. 253). Isso é possível, antes de tudo, devido à subjetividade ser identificada com a temporalidade. Penso que esta passagem de Madison (1990, p. 55) seja clara neste sentido:

\begin{abstract}
não haveria percepção se o sujeito perceptivo não tivesse consciência de si e se não possuísse a si precisamente como uma consciência perceptiva; a doutrina do Cogito clama ser a afirmação do fato que ser consciente é ser, ao mesmo tempo, consciente de ser consciente. Mas o que para Merleau-Ponty deve ser notado é que a certeza que o sujeito tem de ver (a presença de si para si) vem, não de um $a$ priori coincidente de sua consciência a si, mas ocorre exatamente no ato da percepção; isto é, o sujeito descobre e possui a si somente na base de seu contato atual com coisas e com o mundo.
\end{abstract}

Dizíamos antes de uma generalidade corporal de onde era possível afirmar uma relação pré-pessoal com o mundo, mas que desenhava a história pessoal do sujeito. Entretanto, esta generalidade está sob dependência da generalidade da subjetividade (PhP, p. 459), porque uma não se realiza sem a outra: eu só sou no mundo porque sou para mim e só sou para mim porque sou no mundo. Do mesmo modo é indeclinável (PhP, p. 459): uma 
generalidade inegável, que não pode ser sem estar em relação, ou se afastando, da outra generalidade.

Não é de se estranhar também, neste caso, que Merleau-Ponty apontasse então que “a generalidade do corpo (...) é exatamente compensada por esta outra generalidade de minha subjetividade inalienável” (PhP, p. 411). Ou seja, o sujeito jamais se reduz às situações de fato: ele se engaja no mundo, mas reconhece esta ação como sua. Aliás, só pode se reconhecer como um ser para si ao realizar um ato particular: aquém de todo ato há uma unificação das experiências do sujeito. A consciência de si não exclui o fato de ser um ser-no-mundo e viceversa: “eu sou dado a mim sendo no mundo” (PhP, p. 466).

É deste modo que Merleau-Ponty pode afirmar que “a generalidade e a individualidade do sujeito, (...) o anonimato de indeterminação [on] e o anonimato da consciência, não são duas concepções do sujeito entre as quais a filosofia teria que escolher, mas dois momentos de uma estrutura única que é o sujeito concreto” (PhP, p. p. 514). E como negar que este sujeito concreto é o corpo próprio? É pelo corpo, ou seja, nas experiências (en train de) que podemos unir o ser para si e o ser no mundo.

Mas também não há como negar que o corpo, tomado concretamente, só pode realizar esta junção porque "toma posse do tempo": “em cada movimento de fixação, meu corpo ata em conjunto um presente, um passado e um futuro, ele secreta tempo (...). Meu corpo toma posse do tempo, ele faz um passado e um futuro existirem para um presente, ele não é uma coisa, ele faz o tempo em vez de padecê-lo” (PhP, p. 277). Quer dizer, é o corpo que torna manifesto aquela presença de si a si mesmo numa situação dada, num campo de presença.

De certo modo, a subjetividade apontada na fenomenologia merleau-pontyana só pode se manifestar enquanto “corpo”: "se o sujeito está em situação, se ele não é nada senão uma possibilidade de situações, é que ele só realiza a sua ipseidade sendo efetivamente corpo e entrando por esse corpo no mundo” (PhP, p. 467). Acompanhemos como Geraets (1971, p. 
179) parece partilhar também desta constatação: “nossa experiência desta unidade viva de nós mesmos e do mundo se concentra, como em sua origem e sua manifestação mais original, na experiência do corpo próprio”. Tomemos ainda esta outra passagem de Merleau-Ponty: “(...) meu corpo como subjetividade faz um com minha existência como corpo e com a existência do mundo e, finalmente, o sujeito que sou, concretamente tomado, é inseparável deste corpoaqui e deste mundo-aqui” (PhP, p. 467). É porque o corpo tem o “poder” de tomar posse do tempo ao tornar expresso uma relação no mundo, mesmo que seja necessário que haja um “fundo existencial”, uma "generalidade” a partir da qual se esboça todo ato particular, como a afirmação cartesiana do cogito. Ora, se a subjetividade, em última instância, é temporalidade, é necessário que o tempo “surja” por meio do corpo: “ele faz o tempo”.

Uma conclusão importante a que chegamos aqui é que não se deve apenas dizer que o sujeito é tempo, mas que a temporalidade se manifesta no ser no mundo, num sujeito encarnado, capaz, por exemplo, de realizar sínteses de percepção num campo de presença, no presente vivo. Ferraz (2006, p. 206) é preciso: “se a esfera subjetiva é identificada à temporalidade, e se essa é uma modulação da vida corporal, fica então claro que a subjetividade remete à existência encarnada”. Sendo assim, podemos agora articular a presença de si, a relação de um sujeito corporal com o mundo e o modo como esta articulação se realiza: mediante a temporalidade. O “segredo" desta articulação, me parece, se manifesta neste "poder" do corpo de tomar o tempo em toda relação com o mundo, onde cada ato torna expressa esta posse.

Há, porém, uma breve passagem de Merleau-Ponty que merece ser mencionada aqui: “o Cogito tácito, a presença de si a si, sendo a prórpia existência, é anterior a toda filosofia, mas ele só se conhece nas situações-limite em que está ameaçado: por exemplo, na angústia da morte ou na angústia do olhar de outrem sobre mim” (PhP, p. 462). Esta passagem, a meu ver, é enigmática. O que a diferencia, em primeiro lugar, é que o verbo “conhecer”, no 
contexto, quer dizer conhecimento do "pensamento objetivo" (PhP, p. 463). Mas isso deixa uma margem: é possível uma plena posse de si no caso de ameaça? Por quê? Porque o olhar de outrem pode me angustiar? Esta passagem nos deixa uma "fresta" para podermos questionar o "lugar” do outro na articulação que fiz acima. Aliás, como o outro é dado a mim, segundo a Phénoménologie de la Percpetion? 


\section{Quinto capítulo - A imagem corporal em operação no esquema corporal}

\section{1) Percebendo o comportamento do outro}

De um modo geral, o objetivo deste capítulo é tentar compreender por que MerleauPonty amplia a noção de esquema corporal ao incluir a imagem como algo operante na consciência que temos de nós mesmos como uma unidade: “(...) meu esquema corporal refere-se ao mundo percebido e também ao imaginário” (Sorb, p. 562). Este problema envolve certamente a relação com o outro: "o desenvolvimento da imagem especular, da imagem global do corpo, é solidário com as relações com os outros” (Sorb, p. 527). Como nos diz Aubert (2005, p. 115), por exemplo: “a relação de minha existência encarnada com o mundo e com o outro não faz senão prolongar na exterioridade um comércio de meu corpo com ele mesmo. (...) todo comércio é uma extensão do ‘comércio dos esquemas corporais’”. Entenderemos isso melhor logo à frente.

Para conseguirmos realizar esse objetivo, retomemos a questão colocada no último capítulo: como outrem é dado a mim?

É inegável que o problema da relação com o outro aparece na Phénoménologie de la Perception a partir do problema da consciencia perceptiva. Basta para isto lembrarmos que o subcapítulo sobre Autrui et le Monde Humain está inserido no capítulo Le Monde Perçu. Quer dizer, o outro é, antes de mais nada, um comportamento que percebo (PhP, p. 401). O que isto significa? Para Merleau-Ponty, isto significa fundamentalmente que o outro não é uma coisa 
diante de mim. Ele é um corpo e um corpo que percebo suas condutas. Moutinho (2006, p. 200) nos participa:

todo o problema da intersubjetividade, na Fenomenologia..., é posto por Merleau-Ponty em termos de percepção; à frente diz: (...) o corpo de outrem não é um objeto para mim, nem o meu para ele, como supõe Sartre, mas eles são antes 'comportamentos'. Trata-se aqui do corpo que percebe e do corpo percebido, de dois sujeitos anônimos, não de duas consciências privadas, pessoais (p. 206). Por fim, conclui: o mundo humano não é aqui pensado a partir de um reconhecimento mútuo de consciências, de um reconhecimento que passa por negação recíproca; ele não resulta de uma relação frente a frente entre sujeitos, não é uma república de espíritos extramundanos (p. 216).

Na verdade, o mundo percebido por nós é um mundo imediatamente dado, um mundo prenhe de sentidos: é esta presença imediata que possibilita a Merleau-Ponty pensar a relação com o outro sob esta relação direta. Ou seja, o outro é presente a mim antes de qualquer construção que eu possa fazer dele, ou antes de qualquer analogia. Eu percebo suas condutas, imediatamente dadas, assim como percebo o meu ao redor. Uma passagem como esta confirma esta idéia: “é por meu corpo que eu compreendo o outro, como é por meu corpo que eu percebo as “coisas”” (PhP, p. 216). Esta mesma problemática era proferida em La Structure $d u$ Comportement - algo que destacamos no primeiro capítulo: a criança percebe o sentido do gesto materno, ela retribui um sorriso.

Conseqüentemente, isto nos leva a afirmar que compreendo o sentido da conduta do outro assim como compreendo as motivações que o mundo me desperta: “os gestos de outrem me invadem” (PhP, p. 464). Como nota muito bem Barbaras (2001a, p. 37) num de seus primeiros textos sobre Merleau-Ponty: “ao longo de toda a Phénoménologie de la Perception, a descrição do sensível e do objeto empresta seu vocabulário à experiência do outro, como se fosse no sensível que se cristalizasse os caracteres de toda experiência”. Um outro comentador, Whiteside (1988, p. 61), chega a afirmar que, havendo uma primazia da percepção em todos os atos humanos, “(...) significa que o compromisso que Merleau-Ponty faz com a fenomenologia em seus primeiros trabalhos funciona como um prolegômeno para 
compreensão de todas as experiências. Fenômenos políticos e históricos também devem ter uma fundamentação perceptiva”.

Seja como for, se retomarmos o problema da imitação infantil, talvez isto fique mais claro, pois o problema é o mesmo aqui: o outro percebe minhas intenções em seu corpo porque lhe expresso condutas que ele pode tomar como suas (PhP, p. 404), mesmo não podendo viver do mesmo modo minha conduta (o corpo tem um poder de tomar como sua a conduta, mas não de vivê-la como o outro a vive). Aubert (2005, p. 212) é profundo nesta passagem:

\footnotetext{
para ser reconhecido, todo ser solicita uma unidade expressiva de meu esquema corporal e faz eco, segundo um jogo de entre-expressão que não se executa num meio cristalino do espírito óptico mas na opacidade e ambigüidade de um comportamento, onde meu corpo todo toma por sua conta, 'por um modo de mimetismo', o modo de ser deste ser.
}

Sendo assim, a motricidade indicaria uma “esfera primordial” de significações (PhP, p. 166) que a criança expressaria comunicando-se corporalmente com o mundo e que o outro compreende. Trata-se de pensar o corpo como “corpo animado”, agindo (en train de). Ou seja, trata-se de um comportamento que percebo: “(...) eu não conheço [o outro] senão através de seu olhar, seus gestos, suas palavras; em uma palara, através de seu corpo. Por certo, um outro está longe de ser para mim reduzido a seu corpo, é seu corpo animado de todo modo de intenções (...)” (C, p. 44) que eu percebo.

A criança não poderia compreender o sentido de um sorriso, por exemplo, se visse no outro apenas uma coisa entre outras: “o corpo do outro não é um objeto para mim, nem o meu para ele, se eles são comportamentos, a posição do outro não me reduz à condição de objeto em seu campo, minha percepção do outro não o reduz à condição de objeto no meu campo" (PhP, p. 405). Whiteside (1988, pp. 79-80) percebe isto de modo claro:

a habilidade da criança em aprender uma linguagem (SC, p. 185), inclinações sexuais (PhP, p. 185), a compreensão da expressão facial (PhP, p. 404), tudo isto testifica uma prioridade da orientação humana para outrem não como objeto, mas como um centro expressivo de comportamento(PhP, p. 405; SC, p. 239). 
Significa também que não há como pensarmos que constituímos o outro (assim como não constituímos o mundo). Aliás, como vimos, não há uma consciência constituinte (o que nos levaria a uma pluralidade de consciências (PhP, p. 402)). Por outro lado, não poderíamos também dizer que a relação entre meu corpo e os outros corpos é uma relação de analogia, como se diz numa filosofia solipsista, porque isto suporia algo da ordem do entendimento, posterior à relação direta que percebo do outro. Esta tese é, aliás, de Scheler (1928, pp. 347384; PhP, p. 404), como nos confirma novamente Aubert (2005, p. 117):

para o autor de Nature et formes de la sympatie, nós não constituímos o outro, seja por um raciocínio por analogia ou por um processo de projeção: nós percebemos outrem. (...) Portanto, do mesmo modo que a percepção nos arranca de nós mesmos nos tornando imediatamente presente ao percebido, a percepção de outrem nos permite reunir uma outra existência que nós não temos que construir.

Para Scheler, não há como pensarmos num “julgamento por analogia” ou numa certa “crença na existência do outro” (SCHELER, 1928, p. 347), porque a psicologia infantil nos mostra que a primeira percepção (exterior) da criança é a “expressão”. Scheler (1928, pp. 360361) é preciso: “[a criança está] mergulhada no ‘espírito familiar’, ela não tem primeiramente nenhuma idéia de sua própria vida”.

A meu ver, isto leva Merleau-Ponty a mesclar o exemplo da percepção do mundo ao nosso ao redor com a evidência da psicologia infantil (como veremos à frente): há uma relação direta, uma conexão, ou mesmo uma comunhão de corpos. Há um “comércio direto” do corpo com o mundo e com o outro. Por isso, talvez, dever-se-ia pensar numa intercorporeidade como o primeiro capitulo de um estudo sobre a intersubjetividade na fenomenologia merleau-pontyana:

é justamente meu corpo que percebe o corpo de outrem, e ele encontra ali como que um prolongamento miraculoso de suas próprias intenções, uma maneira familiar de tratar o mundo; doravante, como as partes do meu corpo em conjunto formam um sistema, o corpo de outrem e o meu são um único todo, o verso e o reverso de um único fenômeno, e a existência anônima da qual meu corpo é a cada momento o rastro que habita doravante estes dois corpos ao mesmo tempo (PhP, p. 406). 
Um exemplo notável desta relação de um corpo versus outro corpo nós encontramos ao estudarmos o corpo libidinal: “(...) o desejo compreende cegamente ligando um corpo a outro corpo” (PhP, p. 183). É por isso que se poderia dizer de uma intercorporeidade ou, como diz Aubert (2004, p. 290), de uma “incorporação”: algo que o estudo da psicanálise teria revelado a Merleau-Ponty. Sendo assim, Merleau-Ponty aponta para uma problemática de uma existência versus outra existência, como nos participa Geraets (1971, p. 124): outrem me é dado primeiramente como uma outra existência, e não como uma "consciência estrangeira”. É por isso a primazia da percepção na relação com outrem: basta lembrarmos que a percepção é um ato que nos faz conhecer existências (SC, pp. 240-241, 228; PhP, p. 50). Entretanto, isso não exclui um certo tipo de “solipsismo vivido” (PhP, p. 411) seguindo ainda a esteira de Scheler (1928, p. 373): “estas sensações [sentidas por outrem] não podem jamais ser percebidas por mim diretamente, imediatamente, com a mesma vivacidade como se elas fossem verdadeiramente minhas (...)”. Mas isto não significa, idem, afirmar uma “pluralidade de consciências”: na percepção, eu estou em relação ao outro de um modo direto. A afirmação de uma conexão corporal e um certo tipo de solipsismo vivido torna possível a Merleau-Ponty realizar um certo jogo entre “unidade” e “pluralidade”: ninguém está totalmente isolado do outro (o que nos levaria a uma consciência fechada sobre si mesma), nem está totalmente em reciprocidade com o outro (o que nos levaria à ausência de qualquer individualidade). Com isto, Merleau-Ponty pode afirmar que “unidade” e "pluralidade” não são excludentes, assim como “generalidade” e “possibilidade”.

Se não posso viver a "situação apresentada" pelo outro, mas apenas uma "situação vivida” (PhP, p. 409), certamente estamos afirmando uma presença inalienável de si a si mesmo. Mas percebamos que Merleua-Ponty segue aqui o exemplo da percepção do mundo: eu jamais posso "agarrar a ipseidade” da coisa, ela sempre me escapa, me reenvia a ela mesma e até mesmo me ignora (PhP, p. 372). Do mesmo modo, em relação à percepção de 
outrem: seu mundo é inacessível a mim, mas posso percebê-lo, mesmo não o “agarrando” por completo.

Comparemos, por exemplo, duas passagens. A primeira, referindo-se à relação com outrem: “(...) o corpo de outrem e o meu são um único todo, o verso e o reverso de um único fenômeno (...) (PhP, p. 406). A segunda, à relação com o mundo:

a coisa não pode jamais ser separada de alguém que a percebe, ela não pode jamais ser efetivamente em si, porque suas articulações são aquelas mesmas de nossa existência (...). Nessa medida, toda percepção é uma comunicação ou uma comunhão, a retomada ou o acabamento, por nós, de uma intensão alheia ou, inversamente, a realização, no exterior, de nossas potências perceptivas e como um acasalamento de nosso corpo com as coisas (PhP, p. 370); "eu me engajo com meu corpo entre as coisas; elas coexistem comigo como sujeito encarnado” (PhP, p. 216).

Não há dúvidas ao filósofo: o mundo que partilhamos nos garante um mundo comum, uma coexistência que deve ser vivida por cada um (PhP, p. 410). O que está em jogo aqui é um "fundo comum”, como bem observa Waelhens (1968, p. 251). Em palavras merleaupontyanas: há um “lugar comum” ou um “terreno comum” de coexistência anterior a qualquer conflito com o outro. Aliás, um "lugar pacífico” de onde se poderiam originar conflitos: "para que a luta possa começar, para que cada consciência possa suspeitar das presenças estrangeiras que ela nega, é preciso que haja um terreno comum e que elas se lembrem de sua coexistência pacífica no mundo da criança” (PhP, p. 408). Quer dizer, a criança vive num mundo pacífico onde o outro não é um problema para ela: ela co-existe com o outro (PhP, p. 407). Este será um ponto-chave na nossa discussão mais à frente. Insistamos primeiramente neste “mundo infantil”.

\section{2) Um sincretismo da criança com o outro}

Desde Freud, é um lugar comum afirmar que existe uma indiferenciação, na criança, entre o eu e o mundo, que marcaria originalmente a vida anímica (1953d, p. 116). Isto 
marcaria uma inexistência de uma unidade funcional do corpo da criança pré-matura, o que só poderia ser integrado segundo o desenvolvimento do esquema corporal. Isto não significa necessariamente que não haveria um certo esquema corporal na criança, mas que este esquema corporal sofre re-estruturações diante de novos acontecimentos no seu desenvolvimento. Guillaume (1925, pp. 143-144) é claro neste ponto:

\begin{abstract}
falar do caos de impressões novas do recém-nascido, no qual a ordem se introduz pouco a pouco, é esquecer que a criança é um ser organizado (...) Indiferente ao tempo e ao espaço, pobre em lembranças que lhe fornecem os termos de comparação, fechada à maior parte das fontes de interesse que as coisas apresentam para nós, a criança se mostra anteriormente como uma consciência restrita, mas perfeitamente equilibrada, onde há sempre harmonia entre a percepção e a ação. (...) As subjetividades, a relatividade ao eu de certas qualidades atribuídas aos objetos não é uma idéia da criança, nem mesmo da maior parte dos homens; é uma conquista tardia da análise psicológica.
\end{abstract}

Seja como for, isto nos mostra como o recém-nascido estaria imerso numa sensibilidade predominantemente interioceptiva, estando sua relação com o meio quase que numa sintonia, em que as suas reações ditas primárias moldariam suas condutas de acordo com as circunstâncias, segundo Wallon, por exemplo. Suas respostas aos estímulos exteriores não exprimiriam seu comportamento global ainda, já que seria preciso as reações secundárias, em que já haveria transformações e elaborações de estruturas que prevaleceriam às circunstâncias para destacar suas motivações íntimas. Por isso Wallon diz de um sincretismo no qual não haveria uma distinção entre as relações do eu e do mundo ou qualquer dissociação de subjetivo e objetivo (mesmo que se afirme uma “zona de indiferenciação”, é bom ressaltar que se trata já de uma forma de sociabilidade $)^{1}$. Esta passagem de Huong (1976, p. 191) é bem ilustrativa: “esta sensibilidade emcional é essencialmente sincrética, quer dizer, confusa, global e indivisa. (...) a criança se sente em outrem e sente outrem em si. Uma

\footnotetext{
${ }^{1}$ Zazzo nos indica bem a diferença entre as análises de Wallon e Piaget (o que nos indica por que Merleau-Ponty tende a buscar em Wallon este problema): "Piaget analisa a gênese da lógica, ao passo que Wallon analisa a gênese do homem nas suas relações iniciais com os outros homens. Para Piaget, a socialização da criança é um processo intelectual, a conquista da reciprocidade dos pontos de vista, a partir do autismo e do egocentrismo, para Wallon a socialização mergulha as suas raízes na emotividade, na personalidade global”. (ZAZZO, 1978, p. 141)
} 
verdadeira simbiose afetiva se estabelece, que tem o eu como dissoluto nas relações com outrem”.

Sabemos que Piaget denomina este estágio como um egocentrismo, termo que não poderia passar despercebido a Merleau-Ponty:

para Piaget, a criança é voltada desde o início unicamente para o mundo exterior; nenhum traço de introversão; pelo contrário, um realismo excessivo que não sabe ainda fazer a crítica das coisas: a criança não sabe ainda distinguir o que há de pessoal nessas experiências e toma seu ego pela realidade objetiva; é um estado de indiferenciação entre o mundo exterior e o ego. Assim, longe de significar um excesso de consciência de si, esse conceito põe em evidência a ausência de consciência de si (Sorb, p. 184).

De qualquer modo, o importante é ressaltar que a criança teria apenas uma consciência afetiva do outro e não teria ainda a capacidade de se delimitar do mundo. Isto tornava possível e coerente o que Merleau-Ponty afirmava na Phénoménologie de la Perception: que a percepção de outrem e o mundo intersubjetivo só são problemas para os adultos: “a criança vive em um mundo que ela acredita imediatamente acessível a todos aqueles que a circundam, ela não tem nenhuma consciência de si mesma, nem tampouco dos outros, como subjetividades privadas, ela não suspeita que nós todos e ela mesma estejamos limitados a um certo ponto de vista sobre o mundo” (PhP, p. 407). Este seria o primeiro universo da criança onde haveria uma relação entre si e as outras pessoas, segundo uma indistinção inicial que não permitiria uma individualização do eu e do mundo. Isto é fundamental para a constituição na criança de seu esquema corporal, pois se trata, como afirma Peillon (2004, p. 77), de “uma relação de participação mútua”.

Para Barbaras (2001a, p. 52), esta passagem é determinante a Merleau-Ponty, pois o filósofo

aborda a questão do outro, não a partir do cogito [na Phénoménologie de la Perception], mas de uma corrente psíquica 'indiferenciada' que se realiza numa evidência emocional e que precede as diferenças 
subjetivas. Desta indiferenciação psíquica, Merleau-Ponty busca aliás a confirmação na psicologia infantil, que põe em evidência um 'transitivismo', no nível das primeiras relações intersubjetivas.

De fato, segundo Wallon, o corpo próprio seria experienciado primeiramente na sensibilidade interoceptiva. Não haveira assim uma diferenciação com o mundo, mas certamente poder-se-ia dizer que há uma certa oposição entre o que é expelível e o que não o é: as fezes, a urina e o próprio ato de ejetar tais “partes” suas daria à criança um contato prazeroso e também curioso, como um dos primeiros contatos com o mundo exterior. A respiração, a alimentação e a sucção seriam outras funções que se especializam nesta relação (WALLON, 2002, pp. 187-191). Já na sensibilidade proprioceptiva a criança desenvolveria suas funções motoras e suas espacialidades equilibrativas (WALLON, 2002, pp. 191-193). Caminhar, por exemplo, seria um passo importante para a formação desta equilibração.

Mas, afinal, o importante é entendermos como a criança se desenvolve até uma estabilidade unitária em suas ações, que lhe dê um sustentáculo do sentimento de seu corpo próprio como algo coordenado e unitário (WALLON, 2002, pp. 191-193). Isto nos mostra que a noção de seu corpo próprio não se dá por um resultado de combinações automáticas entre as sensibilidades, mas está correlacionada às suas sensibilidades num estado crescente: "longe de a consciência subjetiva ser originalmente coerente, todas as relações da criança a alguma etapa testemunham que ela se descobre por fragmentos” (WALLON, 1984, pp. 101-102).

Quer seja assim, cada passo da criança seria uma conquista de sua percepção: ela fica atenta quando, espantada, vê aparecer suas mãos. Tal fato, por exemplo, demonstra que não há uma intuição primitiva e necessária do corpo próprio. É se experimentando que ela se explora. Por exemplo, levantando o braço e colocando-o em seu campo de visão: chegará um momento em que será capaz de individualizar esta parte de seu corpo, sem ainda ter de si um

\footnotetext{
${ }^{2}$ Barbaras vê no transitivismo o problema merleau-pontyano, ou seja, numa das últimas formas de confusão entre o sujeito com seu ao redor (ver, por exemplo, Huong, La Formation des Attitudes Affectives, p. 196). Não me parece importante destacarmos detalhadanmente estas fases de “confusão” aqui: o interessante é entendermos que se trata de um certo tipo de sincretismo do eu com o outro e com o mundo.
} 
sentimento de unidade. Guillaume (1925, pp. 88-89) nos diz, por exemplo, ao observar seus filhos, que

todas as partes do corpo da criança não são vistas diretamente por ela; outras são raramente ou sob um aspecto particular; enfim, outras podem entrar no campo visual sem atrair a atenção. (...) Em geral o corpo é visto com vestimentas que o cobrem, mas de um modo incompleto e sempre parcial. As costas, a cabeça, a face não são objeto de nenhum conhecimento visual direto.

De um modo geral, a concordância entre os psicólogos leva Wallon (2002, p. 218) a afirmar que "as observações relatadas por diferentes autores são suficientemente concordantes para permitir que se conclua por uma evolução constante”. Entretanto, o problema teórico entre eles parece ser o modo ou quando a criança se toma enquanto uma unidade.

Guillaume, por exemplo, pensa a imitação como fundamental nesta assunção da unidade corporal. É coerente para o psicólogo que haja um estágio de indiferenciação com o mundo, mas seria a imitação que faria a criança, pouco a pouco, emergir o eu desta indiferenciação (GUILLAUME, 1925, p. 151). Neste caso, a criança, ao tomar a conduta do outro como sua, tomaria pela primeira vez uma consciência de si como unidade. Guillaume (1925, p. 165) argumenta:

\begin{abstract}
mas, dirão, as ocasiões não faltaram à criança de se fazer uma representação visual direta da maior parte de seu corpo e de seus movimentos. Ela se estuda, por exemplo, diante de um espelho e se representa completa em seu aspecto exterior, sua fisionomia, suas atitudes. Nós não cremos que este fato seja negligenciável; ela pode em certas crianças acelerar a imitação dos movimentos e a face das atitudes gerais, e precisar a consciência de si. Mas isto não é menos que um acidente e as crianças que jamais se viram num espelho imitam e se conhecem como semelhantes aos outros homens.
\end{abstract}

Vemos assim claramente um privilégio da imitação sob o que se denomina o "estádio do espelho”. Guillaume (1925, p. 167) caminha para uma alteridade como um fenômeno espelhar: “os outros homens, as outras crianças na sociedade das quais a criança vive, são para a criança o espelho natural que lhe reflete sua imagem quando ela imita”3 .

\footnotetext{
${ }^{3}$ Tese, aliás, que será repensada posteriormente pelo psicólogo (GUILLAUME, 1937, p. 197).
} 
Wallon talvez seja o primeiro a discordar disto, porque este estádio não seria apenas um “acelerador” neste processo, isto porque a visão de si seria o único meio para se poder dar uma consciência de ser visto tal como a criança se vê.

Além disto, veremos que há uma função do olhar ${ }^{4}$ para Merleau-Ponty mais ampla que uma consciência de ser uma unidade corporal: eu vejo e sou visto. Caminhemos para isto.

\section{3) Um certo episódio do desenvolvimento infantil}

Segundo alguns psicólogos, há um “episódio” curioso no desenvolvimento infantil. Trata-se do "estádio do espelho”. Quer dizer, o modo como a criança reage diante de um espelho parece comprovar que sua imagem dá a si uma noção mais exata de seu corpo. Entretanto, é certo que tal percepção não se dá num golpe e está sujeita a uma evolução constante para se ter uma intuição de conjunto de sua unidade corporal: deverá se imaginar como unidade, já que não pode ver todas as suas faces ao mesmo tempo.

Antes de mais nada, seria interessante avaliarmos a reação de um animal diante de um espelho para destacarmos o que é próprio do humano nesta experiência. Os chimpanzés estudados por Köhler (1959, pp. 241-293) são um caso clássico neste sentido. Suas experiências demonstram que os chimpanzés reagem de um modo curioso diante de sua imagem. Primeiramente, olham o espelho. Depois, apalpam-no. Logo já olham atrás dele, como se estivessem procurando algo. Seu interesse diante da imagem, de fato, é

\footnotetext{
${ }^{4}$ Alías, não só aqui, mas principalmente em suas últimas obras. Lembrarmos, por exemplo, de alguns títulos do filósofo: Le Visible et l'Invisible; L'Oeil et l'Esprit. É a partir disto que vemos críticas severas ao filósofo. Um bom exemplo é o texto L'Invisible de la Chair - Lecture de Merleau-Ponty - Le Visible et l'Invisible, "L'Entrelacs - le Chiasme". Ali, Irigaray critica o privilégio "exorbitante" dado ao filósofo ao olhar. Chega mesmo a afirmar que o voyant merleau-pontyanno permanece numa situação incestuosa, pré-natal com o "todo" (IRIGARAY, 1984, p. 162), o que o levaria até a um solipsismo labiríntico (IRIGARAY, 1984, p. 148). É bem interessante o texto de Irigaray, mas levá-lo a cabo aqui ou criticá-lo fugiria de minha meta.
} 
marcadamente mais intenso que entre os gatos ou cachorros, e mesmo entre os pássaros (sabese que seu interesse não diminui tão rapidamente como nestes outros).

Köhler parece concluir que há um certo tipo de reconhecimento nos chimpanzés. Mas o interessante é notarmos que este fato não é essencial a ele. Haveria, talvez, um certo tipo de conclusão prática bem diferente do que costumamos mencionar na aprendizagem infantil, que insiste em repetir um fato aprendido, buscando variantes, assim como nos diz Guillaume (1925, p. 84), por exemplo. Aliás, segundo Köhler, o chimpanzé seria até mesmo capaz de se reconhecer num retrato ou de ter uma certa “paixão” pelo espelho. Certamente, os chimpanzés são "seres singulares” pela cativação que têm de sua imagem, mas o caso é diferente na criança, porque envolve a noção do possível: a criança busca novos pontos de vista diante do espelho.

Sabemos, entretanto, que a criança não é sensível à sua imagem nos primeiros dias após o nascimento. É necessária uma certa maturação dos seus órgãos para coordenar sinergeticamente o seu equilíbrio (sua função postural). Assim, ela começaria por uma indiferença frente à sua imagem, fixando-a, sem nenhum interesse na sua fisionomia. Após algumas semanas, ela passa a se olhar como se sua imagem fosse a de um estranho (na décima sétima semana) e demonstrará interesse pela sua fisionomia e nas representações dela, depois de alguns dias (WALLON, 2002, pp. 222-226). Wallon nos diz que a criança passará a sorrir à imagem sem associá-la a si, mas não será ainda capaz de compreender que uma imagem reflete uma pessoa. Para tanto, deverá ter a capacidade de associar a imagem à pessoa (WALLON, 2002, pp. 222-226).

Quando isso acontece, a criança começa a desenvolver a capacidade de identificação, justaposição e associação, dando-a liberdade para se voltar da imagem à pessoa refletida (quando esta lhe dirigir a palavra, por exemplo) (WALLON, 2002, pp. 226-234). Contudo, ela ainda trata a imagem como uma realidade independente da pessoa, pois tal identificação 
pressupõe uma relação de subordinação, ou uma capacidade de representar as coisas "num plano superior”, ordenando as imagens refletidas ao seu redor. Wallon entende este processo como uma duplicação: não haveria uma redução do outro à sua imagem. Um último passo seria a capacidade de representar as coisas, ou de sair de sua existência imediata para se poder imaginar, ou se tomar como um “corpo total” (WALLON, 2002, pp. 234-237).

Seria então progressivamente que a criança poderia assimilar a si como um corpo diante de outros corpos. Resumindo: a imagem especular, para Wallon, seria um momento “episódico”, mas essencial no desenvolvimento infantil.

Seja como for, sabemos que esta interpretação não poderia ser levada a cabo por Merleau-Ponty, pois Wallon acaba por dizer de uma “síntese” que depende do “eu penso”: da capacidade de "representar” ou de "associar”. Isto não explica por que a criança é cativada pela imagem de si, mas "apenas" supõe um desenvolvimento da capacidade cognitiva do sujeito.

A psicanálise parece dar uma explicação mais sugestiva. Como diz Ogilvie (1987, p. 104): “não é o que faz a criança (...) que interessa aqui ao psicanalista, mas o fato de que ela o faça”. Fato não despercebido por Merleau-Ponty:

a interpretação de Wallon deve ser completada: quando Wallon sugere que há unidade entre meu corpo e o do outro, ele vai mais longe do que quando fala da imagem especular. Com efeito, Wallon caracteriza bem a imagem como não-real; ele mostra bem como a criança aprende a reduzir a imagem, mas não diz por que a imagem especular da criança o interessa nem por que acha essa experiência tão divertida. É o que os psicanalistas tentam nos fazer compreender (Sorb, p. 318).

Estes “psicanalistas” dos quais Merleau-Ponty nos diz acima, certamente, podem ser postos no singular: trata-se do “estádio do espelho”, descrito por Lacan, como ele muitas vezes se referiu no curso de Sorbonne. O filósofo observa aí dois pontos importantes sobre a imagem especular no desenvolvimento da criança:

1. a imagem visual que a criança tem de seu corpo é muito incompleta;

2. o corpo é colocado sob a jurisdição do visual (Sorb, p. 527). 
O primeiro ponto já foi esboçado, de certo modo. Quanto ao segundo, devemos tomar a teoria lacaniana para entendermos melhor.

\section{4) O poder formativo da imagem}

Ao estudarmos o membro fantasma, vimos que Merleau-Ponty pensava neste caso como um movimento geral do ser-no-mundo (PhP, p. 117). Vimos que isso não anunciava um problema da imagem corporal, como afirmava Lhermitte, por exemplo, mas seguia o novo estatuto do saber corporal que o filósofo nos apontava. Isso possibilitava a Merleau-Ponty descrever o ser-no-mundo segundo a consciência perceptiva, como dissemos. Analisemos agora um outro modo de pensar. Percebamos a imagem corporal em operação com as primeiras análises do Dr. Lacan. Estas aspas nos levarão a repensar o estatuto do outro em Merleau-Ponty, pós Phénoménologie de la Perception.

Para Lacan (1999, p. 8), no caso do membro fantasma, “é como se tivéssemos um olhar sobre a relação existencial do homem com sua imagem do corpo, nesta relação com um objeto narcísico tal como a ausência de um membro”. Para este psicanalista, trata-se de algo que normalmente a filosofia tem deixado para trás: o poder formativo da imagem (LACAN, 1999, p. 8; 1966, pp. 95-96). Quer dizer, a imagem induziria o próprio desenvolvimento da criança. Este poder formativo é algo que, segundo Lacan (1966, p. 104), a psicanálise seria a primeira a revelar - “(...) o nível de realidade concreta que ela [a imagem] representa”. Noutras palavras, a imagem não seria algo passivo, mas exerceria um certo poder no desenvolvimento da personalidade da criança.

Lembremos primeiramente que a imagem, entendida por Lacan, é algo herdado da Gestalttheorie: uma forma. Esta idéia nós podemos ver em Au-delà du "Principe de réalité" 
(de 1936), por exemplo. Seu primeiro cuidado no texto é de criticar as teorias associacionistas, substituindo-a pela Gestalttheorie em prol da "revolução" freudiana (LACAN, 1966, pp. 73-78), pois os fenômenos mentais jamais poderiam ser explicados por uma associação ou por um mecanicismo, para Lacan. Ora, a psicologia associacionista reduziria a imagem a uma função de ilusão, empobrecendo os dados concretos da imagem e impossibilitando-nos de reconhecer o sentido de um grande número de fenômenos psíquicos.

O que é fundamental a Lacan (1966, p. 77) é afirmar o poder da imagem: um poder de formação ${ }^{5}$, isto é, sua função é formadora da configuração do organismo. Numa passagem clara sobre este problema, Marcos nos participa: “a imagem forma. Ela não reproduz, mas configura. Ela faz entrar em uma forma, ela ‘formata’ ou conforma. Sua consistência própria e sua potência intrínseca de organização determinam uma circunstância psíquica singular” (MARCOS in SAFATLE, 2003, pp. 34-3465).

Mas também lembremos que a imagem não tem o mesmo estatuto do percebido: perceber um objeto é assumir que o objeto é inesgotável, que ele me é dado numa infinidade de perfis (o que nos levou ao problema do indeterminado positivo, da perfilação, do reenvio em Merleau-Ponty). Imaginar é algo distinto disso: uma imagem é sem profundidade, sem ponto de vista, não pode ser observada, e é nos dada de uma vez por todas. Merleau-Ponty confirma esta idéia: “a imagem não é uma percepção enfraquecida, ela não é suscetível de ser ‘observada’, isto é, examinada ponto por ponto como uma coisa percebida” (Sorb, p. 225).

Mas, para o filósofo, posso realizar uma síntese presuntiva da totalidade de uma coisa. Nada me obriga a dizer de uma tomada de consciência absoluta de um objeto, porque estou sempre neste campo de abertura, nesta síntese em transição: "não é por acidente que o objeto se oferece deformado a mim, segundo o lugar que eu ocupo; é a este preço que ele pode ser

\footnotetext{
${ }^{5}$ Seguimos a sugestão de Jean-Pierre Marcos de traduzir este termo como função de “formação”, e não de “informação”, por motivos de clareza (MARCOS in SAFATLE, 2003, p. 345).
} 
‘real'” (PP, p. 48). É o próprio horizonte (de inesgotabilidade de aparições) que me assegura a identidade do objeto. É a partir desta abertura que posso dizer de uma “síntese perceptiva”.

Por exemplo: quando vejo este cubo na minha frente, posso ver no máximo três faces de cada vez, mas estas faces me reenviam às suas outras faces. Eu não estou vendo estas outras faces, mas sei que elas estão ali. Na verdade, o lado não visto é, de certa forma, um lado antecipado, do qual posso colocar minha mão, como um visível por vir, presente, ainda invisível para mim. É um lado imanente à minha visão; ausente ao meu perfil; possível ao meu rodear: “a percepção é a síntese de todas as percepções possíveis; essa síntese é realizada pelo poder que possuo de me deslocar” (Sorb, p. 542).

Mas perguntemos: acontece o mesmo caso na consciência que temos de nossa unidade? É certo que cada parte que vejo do meu corpo pode reenviar às suas outras partes, assim como os lados que vejo deste cubo reenviam às suas outras faces. Mas não posso rodear meu corpo: “(...) eu não sou um objeto que se poderia perceber” (PhP, p. 438; SC, p. 230). Ainda: “eu não estou diante de meu corpo, estou em meu corpo ou, antes, sou meu corpo” (PhP, p. 175). Esta é uma diferença fundamental, porque eu não posso rodear meu corpo como rodeio em torno desta tela na minha frente. Não sou uma coisa como esta tela. Percebamos isto nas linhas de Barbaras (2005a, p. 207):

o corpo é um ser ambíguo: é uma coisa, mas uma coisa que é minha, ou melhor, que eu sou. A experiência que se tem se assinala com efeito pelo indício que o torna incomparável aquele dos outros corpos. Enquanto uma coisa se caracteriza pelo fato que eu posso 'Ihe dar a volta', multiplicar à vontade os pontos de vista sobre ele, meu corpo se apresenta sempre do mesmo lado: sua presença não é o inverso de uma ausência possível, ele está comigo e não diante de mim.

Mas em que momento a criança consegue tomar a si como uma unidade? Não se trata neste caso (neste primeiro momento) de uma imagem?

É certo que o filósofo dizia que a consciência do corpo invade o corpo (PhP, p. 90) e também que há um certo tipo de “percepção interior” (fundamentada pela temporalidade) que opera do mesmo modo que a percepção exterior: “ela envolve o infinito, ela é uma síntese 
jamais acabada e que se afirma, mesmo que ela seja inacabada” (PhP, p. 439). Poder-se-ia dizer ainda de um saber corporal. Por exemplo: ao dizermos que não é preciso que eu represente o espaço do meu carro para passar num beco, afirmo que tenho um certo saber do espaço que o carro ocupa como se este espaço fosse uma “dilatação” do meu espaço corporal. Haveria uma “síntese corporal” (PhP, p. 174) que justificaria esta “anexação corporal”: assim como dizemos que meus óculos são como um “índex” de meu corpo, ou que a bengala de um cego é um instrumento com o qual ele percebe (PhP, p. 178), dizemos que os óculos são “um apêndice do corpo, uma extensão da síntese corporal” (PhP, p. 178), ou uma “dilatação corporal”, que só é possível devido a um “saber” de uma unidade corporal assumida e mesmo "flexível”6.

Poder-se-ia ainda dizer do movimento corporal como aquilo que unifica o corpo. Tese defendida por Silva-Charrak (2005, p. 43), por exemplo: “é o movimento que atesta, segundo sua facilidade, sua fluidez ou sua espontaneidade, uma capacidade a se situar no espaço e a se perceber como um todo, quer dizer, a atribuir cada uma das suas partes de seu corpo próprio a si mesmo”. Isto significa que há uma “unidade motora” ou um certo tipo de "movimento de existência”, um sistema onde todas as partes se interagem, como num único sistema, um único “órgão": uma unidade de certo modo autônoma que não depende expressamente de uma consciência, mas de uma potência motora.

Seja como for, o problema, a meu ver, continua: mesmo que a criança aja como um todo, podemos ainda perguntar em que momento ela se sabe como este todo. Mesmo que aos poucos a criança comece a identificar suas mãos como suas, seus pés, se distinguindo aos poucos do corpo da mãe, em qual momento ela seria capaz de se saber como este todo (já presente como potência motora)?

\footnotetext{
6 Trata-se assim de um "saber corporal” diferentemente do que nos diz Schilder (1950, pp. 203-210), por exemplo, ao afirmar que esta anexação é uma anexação de ordem da "imagem do corpo”, uma dilatação do “esquema corporal” que tem a imaginação em operação.
} 
Percebamos que isso não é uma mera especulação dos "saberes empíricos": isso poderia nos indicar um modo de relação original entre a criança consigo mesma e com o outro. É um fato que a criança se toma, se sabe, num certo momento de seu desenvolvimento, como um todo (mesmo que esta unidade não seja uma unidade “real”, uma vez que está sempre aberta a novas sínteses, assim como das coisas à nossa frente, ou sendo uma unidade “presumida” num horizonte de experiência (PhP, p. 254)). É certo ainda que Merleau-Ponty buscava na própria noção de percepção algo correlativo à unidade do corpo próprio (PhP, p. 369), chegando a afirmar que “a teoria do esquema corporal é implicitamente uma teoria da percepção” (PhP, p. 239). Isso quer dizer que há uma correlação entre o esquema corporal, a percepção e os objetos transcendentes (PhP, p. 270), porque meu corpo tem uma textura comum a todos os objetos (PhP, p. 272). Mas Merleau-Ponty parte do fato de que não se pode apreender o corpo senão "assumindo-o” (PhP, p. 239). Ou ainda, "se ainda se pode falar, na percepção do corpo próprio, de uma interpretação, seria preciso dizer que ele se interpreta a si mesmo” (PhP, p. 175). Ele não aponta um momento específico que justificaria esta assunção da unidade corporal ou a interpretação deste fato. Certamente, esta passagem tem conseqüências, como veremos logo a seguir.

A meu ver, é ao analisar o “estádio do espelho” que o filósofo parece apontar este problema: há um momento específico no desenvolvimento em que a criança se toma como uma unidade corporal: ao assumir sua imagem como sua ${ }^{7}$. No momento em que isto se dá, a criança ultrapassa o “fantasma do corpo fragmentado”, algo que Lacan (1966, P. 42) encontra ao estudar alguns sonhos e sintomas. Esta fragmentação levaria a criança a uma experiência de angústia frente um “corpo despedaçado”, que só seria ultrapassado com a conquista da assunção da sua imagem corporal, segundo o psicanalista. A idéia é simples: a imagem forma.

\footnotetext{
${ }^{7}$ Percebamos: eu assumo uma imagem - porque ela não é dada de imediato. Diferentemente, eu não posso assumir uma percepção, uma vez que já estou percebendo (num modo “indeterminado”, e não numa ação “pessoal”).
} 
Para Lacan, o acontecimento de assunção da imagem corporal pela criança, seja se vendo pelo espelho, seja pela imagem do outro, seria o marco onde a imagem de si começaria a ter uma função de integração do corpo, dando sentido ao esquema corporal: “(...) a imagem de si seria esta Gestalt que fornece ao sujeito uma totalidade ideal que ele não tem à sua disposição por meio da percepção de si” (SAFATLE, 2006, p. 78).

Kelh nos ajuda a entender a importância disto:

a assertiva 'eu sou' não esclarece quem eu sou, nem o que sou. Faz-me apenas saber que existo. As outras são certezas que se constroem ao longo da vida. Mas a identificação do sujeito consigo mesmo, o reconhecimento de que ele é este, apenas este, e não outro qualquer, se constitui precocemente. Só a partir desta certeza, os atributos conquistados e as identificações secundárias adquirem sentido e formam uma unidade razoavelmente coerente (KEHL in BUCCI; KEHL, 2004, p. 148).

Se a partir de então a criança “perde” a deiscência originária, assim como a angústia do “despedaçamento”, é porque a imagem tem um poder, que num primeiro momento Lacan (1966, p. 96) aproxima ao poder de estabelecer uma relação do organismo à sua realidade. Nisto entendemos algo fundamental: a imagem nos cativa (LACAN, 1966, p.181). Não é por acaso que existe um interesse da criança com sua imagem: "sua alegria é devida a seu triunfo imaginário ao antecipar o grau de coordenação muscular que ainda não alcançou verdadeiramente” (LACAN, 1999, p. 10, grifo meu) ${ }^{8}$. Quer dizer, o triunfo imaginário coloca em cena a gênese do esquema corporal.

\footnotetext{
${ }^{8}$ Aliás, haveria aqui um "gozo" de unificação que nos leva a pensar a relação de existência entre a criança e o outro: "seu corpo [da criança] experimenta satisfação e júbilo a cada vez que essa unidade é re-atualizada, e, inversamente, toda sorte de agressividade será provocada pela ameaça sentida contra posse de tal imagem" (DUNKER, 2006, p. 18).
} 


\section{5) Um poder também alienante — um espetáculo especular?}

Entretanto, isto tem um preço: a imagem tem também um poder alienante, segundo o psicanalista. Não é só a imagem que cativa, mas também o outro (LACAN, 1975, p. 144), porque a imagem de si é como um outro.

Lembremos para isto que o termo “formação" nós já encontramos em Freud em muitos momentos de sua obra. Por exemplo, ao dizer da formação do sintoma, da formação do analista e, principalmente, da formação do inconsciente. O termo alemão é Bildung, e sabemos como ele tem uma história longa na tradição romântica (que não podemos remontar aqui), que não é exatamente como Freud o toma. Ela está mais próxima de algo híbrido. Quer dizer, se, como nos diz Freud, o inconsciente nos é inacessível, ser-nos-ia acessível sua formação: entre o eu e o isso; ou entre o eu e o supereu.

Em Lacan, esta idéia é da ordem de um reconhecimento, mas também de um distanciamento: quando se diz que a imagem forma, diz-se, ao mesmo tempo, que eu só me reconheço como Eu exatamente por me exteriorizar, me alienar (LACAN, 1975, p. 145). Ora, se a criança passa a ter uma noção mais exata de si ao se ver no espelho, é porque ela passa a introjetar sua imagem, o que também pode acontecer introjetando a imagem do outro. $O$ importante é entendermos que esta introjeção é advinda do exterior. Conseqüentemente, como nos diz Safatle (2006, p. 77), “o eu-corpo próprio é assim uma imagem vinda do exterior. A auto-referência é referência à imagem de um outro na posição de eu ideal. O que nos mostra que não há nada de próprio na imagem do corpo”. Se a criança introjeta algo exterior a ela, é porque ela só pode se ver exteriorizando-se. Noutras palavras, ela só pode se ver alienando-se: a criança só se referiria a si submetendo-se à referência do outro. Nas palavras do psicanalista: “o ser humano não vê sua forma realizada, total, a miragem de si mesmo, senão fora de si” (LACAN, 1975, p. 160). 
Como vemos, é exatamente a formação do Eu que está em jogo aqui. O próprio título da comunicação de Lacan nos indica isto ${ }^{9}$ : Le stade du miroir comme formateur de la fonction du Je - telle qu'elle nous est révélée dans l'expérience psychanalytique. Neste sentido, para o psicanalista, o Eu é algo preso à tópica do Imaginário. Ou seja, a criança toma consciência de si enquanto uma unidade ao se alienar na imagem do outro: é assumindo algo que não lhe é próprio que ela se toma enquanto Eu.

Percebamos que não há uma escolha: é nesta experiência com o outro que a criança se apreenderia como corpo, ao assumir a imagem do outro: a criança se conheceria pela primeira vez como corpo (LACAN, 1975, p. 192). É necessário que a criança assuma sua imagem corporal como sua para se reconhecer como Eu diante de outro.

Se não há como escapar disto, há uma conseqüência inevitável para Lacan: as relações intersubjetivas seriam marcadas pelo reino imaginário. É a partir desta imagem assumida que eu me reconheceria no outro, o que equivalerá dizer, em “lacanês”, que o outro é para mim um objeto fantasmático. Ou ainda: as relações intersubjetivas são relações fantasmáticas, porque o outro é portador imaginário da minha posição de sujeito. Ele sustenta minha posição de imagem, tornando possível uma identificação imaginária ${ }^{10}$ (a partir do poder formativo e cativante da imagem), numa contínua introjeção de imagens ideais do outro que guia o desejo do sujeito (LACAN, 1975, p. 162).

Tomemos nota para onde isto aponta: os vínculos sociais estariam numa esfera onde a identificação entre os sujeitos seria guiada por imagens idealizadas, marcadas por uma lógica própria do imaginário. Ora, isto nos leva a pensar que a nossa imagem corporal determina nossa relação com o outro ao ponto da psicanálise estar debatendo hoje, entre várias outras

\footnotetext{
9 Realizado no XVI congresso internacional de psicanálise, em Zurique 17/07/1949. Na verdade, há uma comunicação de 1936 que Lacan apresentou, em Marienbad, sobre o estádio do espelho, intitulada: The looking glass phase. Mas não iremos tomá-la aqui, já que esta teoria ganha sua força e seu acabamento a partir da comunicação de 1949.

10 "Nesse aspecto, o eu se mostra uma formação imaginária, sempre precária e instável, sujeita ao desiquilíbrio induzido pelo outro, capaz de ‘desfocar’ a imagem de si” (DUNKR, 2006, pp. 18-19).
} 
coisas, “o sentido da vida” na redução da "produção” de um corpo (KEHL in BUCCI; KEHL, 2004, p. 176). Kelh nos aponta isto, de um modo muito interessante, num texto intitulado Com que corpo eu vou?:

que corpo você esta usando ultimamente? Que corpo está representando você no mercado das trocas imaginárias? Que imagem você tem oferecido ao olhar alheio para garantir seu lugar no palco das visibilidades em que se transformou o espaço público no Brasil? Fique atento, pois o corpo que você usa e ostenta vai dizer quem você é (KEHL in BUCCI; KEHL, 2004, p. 174).

Sem nos prolongarmos no desdobramento desta problemática, que surge nas linhas lacanianas e que é fundamental no debate das relações dos vínculos sociais, devemos antes ressaltar como isto segue uma lógica do imaginário. É esta lógica que nos interessa aqui. Safatle (1997, p. 64) a resume:

a lógica do problema da identificação imaginária é, pois, a seguinte: ao fazer referência a si, o sujeito acaba, necessariamente, referindo-se a um outro. A razão é simples: este 'si' ao qual o sujeito se refere é um moi constituído a partir da introjeção da imago de um outro, ou seja, ele se refere a um objeto fruto da sedimentação de captações especulares depositadas durante toda a história do sujeito (...). Ele é ilustrado através da frase de Rimbaud: 'Je est un autre'.

Para entendermos isto melhor, temos que entender que a imagem, para Lacan (1966, p.

95), funciona como uma imago: assumir uma imagem é assumir uma imago: "uma tal teoria pode ser considerada psicanalítica na medida em que trata da relação do sujeito com seu próprio corpo em termos de identificação a uma imago, que é a relação psíquica por excelência” (LACAN, 1999, p. 7; 1966, p. 188). Esta imago não se confunde com uma lembrança que determinaria a conduta, mas teria um regime prospectivo, como resume Merleau-Ponty:

a imago no sentido freudiano não significa representação sensível nem atual mas um centro implícito da conduta. Por exemplo, um homem pode não pensar nunca nas lembranças traumatizantes de sua infância que presidem a tudo o que ele faz. Ele permanece tributário delas e sofre a dominação presente dessas experiências passadas. Lacan tende a substituir a noção de 'inconsciente' pela de 'imaginário' [LACAN, 1966, p. 183]. A imago, por exemplo, em vez de ser 'inconsciente', enterrada na profundidade, deve ser considerada uma formação 'imaginária’, ou seja, projetada diante da consciência. Em suma, Lacan substitui a concepção retrospectiva por uma concepção prospectiva (Sorb, p. 109). 
Seja como for, “a história do sujeito se desenvolve em uma série mais ou menos típica de identificações ideais que representam o mais puro dos fenômenos psíquicos onde elas revelam essencialmente a função de imago” (Sorb, p. 178). Neste sentido, o “estádio do espelho”, descrito pelo psicanalista, deve ser compreendido “(...) como uma identificação no sentido pleno que a análise dá a este termo: a saber, a transformação produzida no sujeito quando ele assume uma imagem (...)” (LACAN, 1966, p. 94).

Para Lacan, (1966, p. 94) o fundamental nesta teoria do “estádio do espelho” é indicar que “(...) essa forma situa a instância do eu, desde antes da sua determinação social, numa linha de ficção, definitivamente irredutível para o simples indivíduo (...)”. Ou seja, Lacan consegue operar o "lugar do sujeito", juntamente com o lugar do reconhecimento do desejo do sujeito, dentro do domínio do Imaginário. Esta operação lhe era fundamental, porque lhe permitia livrar das “confusões” da noção freudiana de narcisismo primário (seria preciso que o ego fosse desenvolvido, já que uma unidade comparável ao Eu não poderia existir desde a origem (LACAN, 1975, p. 59) $)^{11}$, e também, ao mesmo tempo, inserir a lógica kojèveana do desejo (o desejo do homem é o desejo do outro), como nos salienta Safatle (1997, pp. 58-68).

\section{6) Esboço de um conflito na relação com o outro}

Como se pode ver, o problema da imagem corporal está bem distante da fenomenologia de Merleau-Ponty ${ }^{12}$. Há uma diferença fundamental aqui: a intersubjetividade

\footnotetext{
${ }^{11}$ A consciência deveria ser assim pensada sem um ego primordial: “ou seja, de uma consciência impessoal situada em um campo desprovido de egoidade. Se o eu é um objeto, a consciência será uma espécie de olhar que constrói e sustenta tal objeto” (SAFATLE, 1997, p. 70).

${ }^{12}$ É claro que há também muitas proximidades entre ambos. Por exemplo, como diz Safatle (1997, p. 62): “creio mesmo que podemos dizer que a psicanálise traz a noção do corpo como espírito encarnado. O corpo libidinal é um tecido costurado pelas mãos inconscientes do espírito (ou, para ser mais específico, pelas mãos inconscientes de um universo simbólico lingüisticamente estruturado). 'Nós pensamos com o nosso corpo, segundo modos que nos escapam’ (...)”. Ou dando a palavra a Baas (1998, p. 59): “era preciso procurar uma fenomenologia que fazia
} 
para Lacan (que aparecia no Seminaire I) é uma intersubjetividade imaginária, porque a criança se reconhece como sujeito e é reconhecida como sujeito ao se alienar na imagem do outro. Mas o que significa pensar uma intersubjetividade imaginária? Trata-se, antes de qualquer coisa, da descrição dos modos de racionalização dos vínculos sociais. Safatle, por exemplo, nos diz que, dentre outras coisas, em Lacan, isto "significa admitir que há uma dimensão de relação interpessoal que não é relação entre sujeitos, mas é uma relação na qual o outro aparece fundamentalmente na posição de objeto” (SAFATLE in GONÇALVES et al, 2006, p. 145). Curiosamente, após a Phénoménologie de la Perception, é por aí, em certa medida, que Merleau-Ponty caminha. Tentemos compreender o porquê deste caminho.

Antes de mais nada, como nos diz Merleau-Ponty, a psicanálise acentua a essência visual e afetiva do fenômeno: “o visual, para os psicanalistas, não é só um modo sensorial, tem um significado diverso: o visual é o sentido do espetáculo, do imaginário” (Sorb, p. 319). Isto é, quando a criança reconhece como sua a imagem no espelho, ela reconhece igualmente

do corpo a fonte mesma da experiência, e isto fora de toda consideração biológica ou mesmo antropológica; dito de outro modo, uma fenomenologia que pudesse até pensar uma intencionalidade do corpo". Ou ainda: "o interesse de Lacan pela fenomenologia de seu tempo não é (...) um simples efeito da amizade que o ligava a Merleau-Ponty. É porque a fenomenologia moderna, notadamente aquela de Merleau-Ponty, tem principalmente como marco (...) levar-nos aquém da experiência fenomenal (...)” (BAAS, 1998, p. 41). Sendo assim, a fenomenologia merleau-pontyana clareava um problema fundamental ao psicanalista: 1) a constituição da experiência; 2) a constituição do sujeito que experiencia. Isto porque era necessário ao psicanalista questionar a gênese do sujeito para se poder pensar na experiência propriamente dita e nas significações vividas. Trata-se de afirmar que o corpo já está engajado no mundo e com os outros. Como nos diz novamente Safatle (2006, p. 76), parece haver um campo em comum entre o filósofo e o psicanalista: "insistir que corporeidade e ipseidade devem ser articuladas conjuntamente equivale primeiramente a afirmar que o corpo não é um objeto físicoquímico apto a ser submetido ao sistema fechado e mecânico de relações causais próprias de objetos partes extra partes. Sua condição de objeto nunca é plena, já que, ao contrário dos outros objetos do mundo, eu não posso pensar o corpo sob o fundo de sua ausência. O corpo é a perspectiva privilegiada pela qual eu apreendo os objetos do mundo, o que Lacan lembrava ao falar que a imagem do corpo era 'solo do mundo visível'. E como perspectiva, ele não pode ser totalmente objeto. Não há distância entre sujeito e ipseidade, significa assumir não só a subjetividade do corpo, mas também a corporeidade da subjetividade, com todas as conseqüências epistêmicas que tal assunção possa ter. Essa procura Lacan partilhava, por exemplo, também com MerleauPonty, para quem 'nosso corpo não é objeto para um 'eu penso': ele é um conjunto de significações vividas que caminha para seu equilíbrio". Lembremos também que o imaginário em Lacan está mais próximo de uma potencialidade que tem validade enquanto conhecimento, porque está vinculado ao corpo (SIMANKE, 2002, pp. 285-288): trata-se de uma "celebração" dos poderes do corpo. Como nos diz Simanke: "a consciência não tem, em si, nenhum potencial positivo para organizar o caos orgânico originário e dar forma a qualquer coisa semelhante a um outro sujeito. Daí que o ponto de partida do processo de constituição seja o corpo" (SIMANKE, 2002, p. 306). 
que há um espetáculo de si mesma que pode ser visto e que pode ser também o espetáculo de si mesma (RAE, p. 202) ${ }^{13}$. Maria Rita Kelh resume nestes termos o problema:

a certeza subjetiva que nos garante, muito precocemente, que 'eu sou’, não provém da nossa capacidade de pensar, mas de nossa identificação a uma imagem. A imagem corporal. Antes de saber que pensa, o filhote de homem já 'sabe' que existe, a partir do olhar que o outro dirige à sua imagem. Não é o pensamento que garante a singularidade do ser (...). O que nos garante o ser, para um sujeito, é sua visibilidade — para outro sujeito (KEHL in BUCCI; KEHL, 2004, p. 148).

O outro seria assim a "testemunha da visibilidade do sujeito", de sua presença, de sua existência. Ele testemunharia a posição do sujeito na imagem que se tem dele. Merleau-Ponty reconhece este problema como uma relação existencial (Sorb, p. 227), que põe em jogo o poder da imagem, na identificação da criança com o outro, determinando de certo modo as relações e o desenvolvimento infantil.

Percebamos como doravante o imaginário não só está em jogo ao filósofo como é um fato na relação entre a criança e o outro: "visto que a introjeção e a projeção são inevitáveis, minha conduta para com o outro será sempre com alguma consideração carregada de imagens [imageante]” (Sorb, p. 233, grifo meu) ${ }^{14}$. Merleau-Ponty encontra então na tese lacaniana um

\footnotetext{
${ }^{13}$ Aparentemente, isto nos leva ao problema de Le Visible et l'Invisible: haveria uma reversibilidade entre ver e ser visto. Mas não nos precipitemos, como Kaufmann, em igualar a leitura de Merleau-Ponty do "estádio do espelho" com o problema da reflexibilidade da carne, como se se tratasse simplesmente da mesma questão para Merleau-Ponty (KAUFMANN, 1964, pp. 1058-1059). Parece que escapou ao comentador uma distância fundamental: o deslocamento da produtividade do sujeito à produtividade do mundo (da generalidade do corpo e da subjetividade à generalidade da carne). Vejamos o quanto esta afirmação, por exemplo, está distante de nossos problemas: “(...) a barreira entre nós e o outro é impalpável. Não há corte entre o eu e o outro. (...) A constituição de outrem não vem após a do corpo: ambos nascem juntos do êxtase original. A corporeidade a que pertence a coisa primordial é, antes, uma corporeidade em geral” (PO, p. 220). Entretanto, desenvolver esta passagem nos exigiria um novo trabalho.

${ }^{14}$ Lembremos que, anos depois da Phénoménologie de la Perception, em 1959, Merleau-Ponty escreve: “o meu esquema corporal projeta-se nos outros e os introjeta, tem relação de ser com eles, procura a identificação, apresenta-se como indiviso com eles, deseja-os. (...) Schilder: o esquema corporal tem uma estrutura libidinal... e sociológica” (N, pp. 287-288). É certo que a problemática do corpo próprio aqui tem vários elementos novos, como, por exemplo, o conceito de ser bruto ou selvagem, a problemática da estesiologia, do Ineinander vivido e da Empfindbarkeit. Sem pretender ler a problemática do corpo próprio da Phénoménologie de la Perception a partir de uma leitura de notas bem posteriores do pensamento do filósofo, destaquemos como o livro de Schilder (de 1950) é importante nesta questão. Isto nos aponta como definitivamente a noção de "imagem corporal” foi incorporada de certo modo à discussão do corpo próprio em Merleau-Ponty. Ora, para o psiquiatra, há uma conexão de existência entre minhas funções corporais tal como há uma conexão de existência entre meu corpo e a imagem que tenho do meu corpo, assim como há também uma conexão de existência entre meu corpo, minha imagem corporal, meu esquema corporal com o esquema corporal do outro. É exatamente isto que o psiquiatra tenta nos mostrar ao dividir sua obra em três partes que correspondem a isto: The Physiological Basis of the Body-Image; The Libidinous Structure of the Body-Image; The Sociology of the Body-Image. Schilder insiste em nos mostrar que a estrutura libidinal do corpo nos demonstra que o corpo está direcionado ao mundo, está em
} 
modo de re-articular o problema da relação com o outro. Ou seja, não se trata agora, como na

Phénoménologie de la Perception, “apenas” de um problema da percepção do comportamento

do outro,

é preciso que a criança compreenda que há dois pontos de vista dela própria, que seu corpo que sente é igualmente visível não para ela mas para os outros. Há, pois, solidariedade entre desenvolvimento da imagem especular e desenvolvimento da relação com os outros. É para a criança aprender a se ver como um papel (Sorb, p. 526).

Isto modifica profundamente a situação do esquema corporal descrita anteriormente:

“na realidade, trata-se de uma anexação pela criança de sua imagem, de uma tomada de posse

de seu corpo e suas operações vitais estão em estreita relação com a vida afetiva” (Sorb, p.

relação com ele, principalmente com o outro. Esta estrutura libidinal estaria totalmente voltada à imagem corporal, pois toda nossa ação pressupõe um saber da nossa imagem corporal: "quando nós vemos algo, ações musculares começam imediatamente e, imediatamente, trazem uma mudança na percepção do nosso corpo” (SCHILDER, 1950, p. 201). Isto lhe parece claro, principalmente em relação à nossa afetividade: "todo desejo e tendência libidinosa imediatamente muda a estrutura da imagem do corpo (...)” (SCHILDER, 1950, p. 201). Há vários exemplos de casos clínicos que parecem demonstrar a tese de Schilder (1950, pp. 127-145). Mas o mais importante para nós aqui é entendermos que a nossa imagem corporal muda não só do ponto de vista da percepção, mas também do ponto de vista da estrutura libidinal (SCHILDER, 1950, p. 190), e isto é extremamente importante, principalmente se entendermos que a imagem corporal é antes de tudo uma imagem construída em relação ao outro (SCHILDER, 1950, p. 217) e que torna possível, pelo nosso esquema corporal, todas as minhas ações. Finalmente, devemos entender que a "imagem corporal é um fenômeno social", pois “entre o corpo de um e o corpo dos outros existe uma conexão” (SCHILDER, 1950, p. 205). Ora, isto está muito próximo de nossos estudos, principalmente se entendermos que a imagem corporal, como descreve o psiquiatra, é a expressão de nossa vida emotiva, de nossa relação com o outro, o que exclui, desde já, qualquer tipo de intersubjetividade por analogia, ou por uma consciência intelectual: trata-se de uma contínua inter-relação entre o que vejo, sinto, vivo no outro e o que ele vê, sente e vive em mim. Trata-se assim de um problema existencial, porque "nós elaboramos nossa imagem corporal de acordo com a experiência que adquirimos pela ação e atitudes dos outros" (SCHILDER, 1950, p. 299), de nossa relação erótica, desta relação entre corpos: “imagens corporais não podem existir isoladamente. Nós desejamos a relação da nossa imagem corporal com a imagem corporal de todas outras pessoas, e nós queremos isto, especialmente concernindo toda atividade sexual e suas expressões na imagem corporal. Masturbação é um ato especificamente social” (SCHILDER, 1950, p. 237). Haveria assim como que uma sociologia da imagem corporal: há uma comunhão, uma conexão entre minha imagem corporal com a imagem corporal dos outros. Weiss (1998, p. 3) chega a afirmar que “(...) a imagem corporal [para Merleau-Ponty e Schilder] não é nem uma construção individual, nem um resultado de uma série de escolhas conscientes, mas antes, uma atividade operante que tem sua memória, hábitos e horizontes de significação. Ambos acentuam o aspecto intercorporal da imagem corporal, que é o fato da imagem corporal ser por si mesma uma expressão de uma troca contínua entre corpos e imagens corporais”. Certamente, isto nos aponta para uma intercorporeidade, onde o que está em jogo não é somente a noção de corpo, mas também $a$ imagem corporal que tenho de mim e do outro. Aliás, esta parece ser uma característica fundamental da vida psíquica, segundo o psiquiatra, e que determina as contínuas mudanças que temos da nossa imagem corporal (porque, a todo o momento, transformo-a, devido minhas ações em relação ao mundo), assim como das mudanças concernentes “ao centro imaginário do ego" (SCHILDER, 1950, p. 301). Visto isso, entendemos que não é possível dizer de um ego, para o psiquiatra, se não dizemos do outro, pois "nossa imagem corporal não é possível sem o outro" (SCHILDER, 1950, p. 303). Como vemos, Paul Schilder nos leva a um caminho interessante, que Merleau-Ponty retoma no curso sobre a natureza, ao buscar o "lugar" do corpo humano nestes estudos. O problema da imagem corporal parece aí já ser um problema imerso na discussão do corpo próprio. 
481); ou ainda: “compreender a imagem especular é integrar novos dados a seu esquema [do corpo]” (Sorb, p. 527).

Doravante, seria preciso pensar também numa alienação mais "grave”, como diz Merleau-Ponty, que é a alienação ao outro (RAE, p. 203). A criança tem um "papel”: ela testemunha sua visibilidade a partir do olhar do outro. A imagem corporal está agora em operação na relação com o outro. Isto era algo fundamental também a Lacan: se pudermos dizer que a criança se toma como uma unidade, é porque deve haver uma significação especial na conquista do "visual”. "Para Lacan, ser corpo é estar ligado ao olhar do Outro" (SAFATLE, 2006, p. 77). Merleau-Ponty observa:

é toda uma dimensão da experiência que a criança descobre com a imagem especular. Ela pode se contemplar, se observar. A criança constrói para si um eu [moi] visível: um superego, que cessa de ser confundido com seus desejos. A criança é tirada de sua realidade imediata; sua atenção é captada por este eu do qual ela busca o primeiro símbolo na imagem especular: função des-realizante do espelho. Este jogo já realiza, antes da integração social, a transformação do EU [JE]. Produz-se uma alienação do eu [moi] imediato em favor do eu do espelho (Sorb, p. 319).

Isto trás uma conseqüência interessante para Merleau-Ponty: ter um corpo visível significa, antes de tudo, estar num jogo de relações. Se por um lado sou visto, passo a ter um papel em relação ao outro — algo que Lacan demonstrava a partir da idéia de alienação. Ter um papel tem também um preço: um papel em oposição ao outro que modifica a própria personalidade da criança na interpretação merleau-pontyana:

pela aquisição da imagem especular, a criança percebe que ela é visivel, para si e para os outros. A passagem de eu interoceptivo ao eu visível, a passagem do eu interoceptivo ao 'eu especular', como dizia Lacan, é a passagem de uma forma, ou de um estado de personalidade a uma outra (RAE, p. $202)^{15}$.

Mas o fundamental é destacarmos uma instauração de um certo tipo de conflito com o outro, algo que Merleau-Ponty reconhece ser o mérito da psicanálise de destacar, ao descrever, pela primeira vez, as relações da criança com o outro (Sorb, p. 174). Há uma

\footnotetext{
${ }^{15}$ A partir desta assunção, ter-se-ia sentido em acompanhar Weiss (1998, p. 77) em sua análise: "se, como Lacan, Schilder e Merleau-Ponty sugeriram, nós entendermos a imagem corporal como uma projeção morfológica, algo que é formado pela imagem especular do corpo, mas não reduzido a ela, então qual é o efeito produzido (e, possivelmente, destrutivo) desta particular morfologia imaginária do corpo?”
} 
mudança clara aqui: de uma deiscência, pela qual não se poderia dizer de uma oposição ao outro (pois a criança não se delimitaria dos outros ao seu redor), a um jogo de relações de oposição com o outro (ao se tomar enquanto unidade ou assumindo um papel diante do outro). Resumidamente: “há passagem do corpo vivido ao visível e examinado” (Sorb, p. 528).

Isto significa que a criança não só está imersa numa intersubjetividade, como esta intersubjetividade lhe coloca numa “dupla” posição:

Lacan retoma de um modo muito concreto a noção de narcisismo infantil (o estádio do espelho). A contemplação de sua imagem tem para a criança algo de fascinante. Ela experimenta o contraste entre a visão do seu corpo tal como é visto de fora, tal como o outro o vê, e a imagem que ela própria tem do corpo (o contraste entre eu como objeto e eu como consciência vivida) (Sorb, p. 319).

Quer dizer, sou reduzido a objeto ao olhar do outro; mas sou sujeito ao olhar o outro: "o olhar do outro nos esmaga num ponto do espaço quando tínhamos a impressão de sermos ilimitados” (Sorb, p. 326).

Neste sentido, podemos entender, por exemplo, por que Merleau-Ponty destacava, no curso de Sorbonne, a técnica do psicodrama de Moreno: seu método, segundo o filósofo, era capaz de destacar a consciência privilegiada de uma "figura" conflitiva em relação ao outro. Seria assim possível ao indivíduo tomar consciência de seu próprio conflito (por exemplo, entre marido e mulher) quando ele representa e tem representado numa cena seu papel vital (Sorb, p. 474). É exatamente para que o indivíduo perceba como o outro o vê (Sorb, p. 475), para que tome consciência de seu papel em relação ao outro, assim como no caso da assunção da imagem corporal pela criança.

Percebamos um outro exemplo: Guillaume (1925, p. 165) sugere que é a imitação que tornará apta a criança a tomar consciência de si. O interessante é que esta teroria está bem próxima da lacaniana, se considerarmos que o eu, para Guillaume, é construído a partir de um outro. Merleau-Ponty é preciso:

com efeito, para a criança é o outro que ocupa o lugar principal: a própria criança só se considera como um 'outro outro', o centro de seu interesse é outrem. A consciência de um eu único 'incomparável' 
(Malraux) não existe na criança. Este eu é certamente vivido por ela, mas, em todo o caso, não é tematicamente apreendido. O outro é para a criança essencial, o espelho de si mesma ao qual seu eu está preso ('O eu se ignora enquanto é o centro do mundo’, Guillaume) (Sorb, p. 35).

Merleau-Ponty ainda observa que Guillaume utiliza-se do testemunho da linguagem para confirmar esta idéia: “as primeiras palavras da criança concernem ao outro (...)” (Sorb, p. 36). Percebamos como a problemática é a mesma que no caso da interpretação merleau-pontyana do "estádio do espelho”: por um lado, a criança só pode se tomar enquanto eu a partir de uma certa alienação ao outro; por outro, “a criança não poderia compreender o sentido dos pronomes se sua experiência não comportasse já a reciprocidade com o outro” (Sorb, p. 36).

Logo após esta passagem, Merleau-Ponty retoma o problema da existência do outro segundo os olhos husserlianos. A crítica ao filósofo é severa: as Cartesianische Meditationen nos apresenta um solipsismo insuperável, posto que o solipsismo só poderia conceber outrem enquanto um para-si inacessível a mim (Sorb, p. 38). Visto que outrem só me é dado enquanto um comportamento ou um certo estilo, ou seja, enquanto um em-si que é para-si, então “Husserl recusa superar a contradição constitutiva da percepção do outro: não posso admitir reduzir-me à imagem que o outro faz de mim; logo, dado que não consigo colocar-me na perspectiva do outro, não posso também pretender pôr o outro” (Sorb, p. 41).

Como vemos, a superação da perspectiva husserliana é exatamente compor um cenário onde seja possível a coexistência e o conflito. Por isso também a crítica a Scheler: mesmo que este filósofo tenha apontado um solipsismo vivido insuperável, ele acaba por fazer do "mundo infantil” a solução: há uma total indiferenciação entre eu e outrem que me é dado imeditamente (SCHELER, 1928, p. 381).

Novamente Merleau-Ponty retoma o que apontei acima:

não há privilégio a dar à consciência de si; ela é impossível sem a consciência do outro, ela é do mesmo tipo. Como toda experiência, a experiência de si só existe como figura sobre um fundo (a percepção do outro é como o fundo sobre o queal se destaca a percpeção de si), vemo-nos por intermédio do outro (Sorb, p. 42). 
Ambos os filósofos, Husserl e Scheler, tornariam a relação com outrem impossível: por um lado, fazendo um solipsismo insuperável; por outro, impossibilitando pensarmos como alguém pode tomar consciência de si. Por isso, Merleau-Ponty sugere que pensemos que a consciência de si e de outrem só pode se dar numa "situação comum” (Sorb, p. 45, grifo meu) ${ }^{16}$.

\section{7) Um deslocamento sutil}

De certo modo, isto soa muito próximo de uma certa dialética que o próprio filósofo levantava na Phénoménologie de la Perception ao descrever o desejo. Merleau-Ponty retomava ali um "drama” que se desenrolava a partir da famosa dialética hegeliana do Herrschaft und Knechtschaft da Phänomenologie des Geistes, seguindo a esteira da tradição kojèviana ${ }^{17}$. Como sabemos, para Kojève, tratava-se de um embate de reconhecimento entre consciências: a consciência só se satisfaria ao desejar uma outra consciência, reconhecendo a si numa outra consciência, negando- $a$, ao mesmo tempo ${ }^{18}$. Nas palavras de Merleau-Ponty:

\footnotetext{
${ }^{16}$ Percebamos que esta problemática também estava inserida na análise merleau-pontyana sobre o amor. Por um lado, o conflito está presente: "podemos conceber um amor que não seja invasão [empiétement] sobre a vontade do outro?” (RAE, p. 227). Por outro, “aceitar amar ou ser amado é aceitar exercer, aliás, também uma influência, de decidir por outro numa certa medida. Amar é inevitavelmente entrar numa situação indivisa com outro. (...) Estar ligado a alguém é viver ao menos em intensão sua vida” (RAE, p. 227-228). Num outro exemplo, citado por Merleau-Ponty, na "sociabilidade sincrética", podemos vislumbrar um pouco melhor o problema: "quando duas crianças estão juntas, freqüentemente um se exibe e o outro é espectador; um fala, brinca, se mostra, o outro olha (situação análoga à relação entre o senhor e o escravo) (...) O que caracteriza essa relação é que as duas crianças estão de algum modo fundidas na situação. A que contempla só existe pela identificação com o outro. $\mathrm{O}$ despotismo é fundado, sobretudo, no sentimento que o escravo tem de ser escravo, e não na falha do adversário. O que o senhor busca é o reconheciemnto de seu senhorio pelo escravo; não o obtém senão pelo rebaixamento deste: confusão de si e do outro numa mesma situação sentimental” (Sorb, p. 321, grifo meu). Como vemos, Merleau-Ponty diz de um certo conflito diante de um "fusão numa situação". Ambos os processos são como um único fenômeno.

17 Sabemos que Merleau-Ponty (assim como Lacan) foi aluno de Kojève (autor de célebres análises antropogênicas de Hegel na França). Mas, a meu ver, não vem ao caso discutir se a leitura merleau-pontyana é ou não uma leitura fiel a Hegel.

${ }^{18}$ Leiamos, por exemplo, esta passagem: "o homem busca ser reconhecido pelo outro: o simples Desejo (Begierde) torna-se desejo de reconhecimento. (...) Ele deve arriscar sua vida para forç̧ar a consciência do outro. Deve-se engajar uma luta para o reconhecimento” (KOJÈVE, 2005, p. 52).
} 
(...) enquanto tenho um corpo, eu posso ser reduzido a um objeto sob o olhar do outro e não contar mais para ele como pessoa, ou ainda, ao contrário, eu posso tornar, por minha vez, seu senhor ao olhá-lo, mas este domínio é um impasse, porque, no momento que meu valor é reconhecido pelo desejo do outro, este não é mais a pessoa pela qual desejava ser reconhecido, é um ser fascinado, sem liberdade, e que, a este título, não conta mais para mim. Dizer que eu tenho um corpo é então um modo de dizer que eu posso ser visto como um objeto e que eu procuro ser visto como sujeito; que o outro pode ser meu mestre ou meu escravo, de tal modo que o pudor e o despudor exprimem a dialética da pluralidade das consciências e que elas têm uma significação metafísica (PhP, pp. 194-195, grifo meu).

Mas percebamos que há uma diferença fundamental aqui. Isto não guiava o problema da Phénoménologie de la Perception por um motivo muito simples: reparemos que MerleauPonty diz que "eu posso ser reduzido" a um objeto sob o olhar do outro, e não: “eu sou

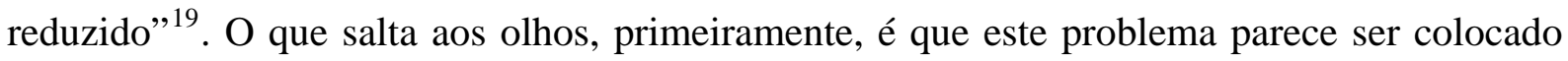
diretamente contra Sartre. Tomemos por exemplo esta passagem de L'Être et le Néan: “a essência da relação entre as consciências não é o Mit-Sein, mas o conflito” (SARTRE, 2006, p. 481). A Phénoménologie de la Perception já ia de encontro a isto: ao afirmar uma relação em que o conflito é possível mas não é o ponto de partida para se descrever o ser-no-mundo em sua relação com o outro, o filósofo já contrapunha a afirmação sartreana do conflito ser o sentido original do ser-para-outro (SARTRE, 2006, p. 413). A questão central então seria pensarmos como é possível uma primazia de um we-subject como sugere Frie ${ }^{20}$.

Entretanto, Merleau-Ponty não dizia em momento algum que não há conflito na relação com o outro. Esta observação de Waelhens (1968, pp. 243-244) é preciosa aqui:

destaquemos de passagem que, contrariamente ao que pensa Sartre, não há uma oposição necessária entre a noção de Mitsein e aquela do conflito. O Mitsein é um existencial cujo conflito é um modo possível. Mas não se pode entrar em conflito com outrem se já não se estiver com o outro.

\footnotetext{
${ }^{19}$ Esta pequena passagem já é suficiente para uma crítica, aos olhos de Butler: Merleau-Ponty estaria aqui assumindo uma tácita normatividade de caráter heterossexual: uma relação de dominação abstrata, voyerística e objetivante, resultante de uma assunção de uma normatividade já sedimentada na cultura (BUTLER, 1989, pp. 92-97). Isto porque, como diz outra feminista, Jéssica Benjamin, seria apenas pela ultrapassagem da relação sujeito-objeto que a relação de dominação poderia ser vencida: uma intersubjetividade mútua, de sujeitos “iguais”, em reciprocidade (BENJAMIN, 1990, p. 29). Entretanto, Butler talvez tenha se precipitado ao não dar o devido valor neste “eu posso ser reduzido”... Aliás, muitos comentadores de Merleau-Ponty parecem “passar por cima” deste “eu posso”. Mesmo na boa análise de Whiteside (1988, P. 80), ele parece não perceber isto.

20 "O we-subject não pode ter primazia, precisamente porque pressopõe a experiência do outro. Nesta base, Sartre ilustra novamente a importância da irredutibilidade da autoconsciência individual, que pensadores que vêem o sujeito como sempre, já numa intersubjetividade, não conseguem explicar. (...) Para Sartre, é o potencial do conflito que determina a natureza do intercâmbio e impede a solidariedade que poderia contribuir para a constituição de um autêntico we-subject” (FRIE, 1997, p. 60 grifo meu).
} 
Percebamos: Merleau-Ponty afirmava um "lugar pacífico" anterior a qualquer conflito: um lugar primordial que posso coexistir com o outro. Quer dizer, o ponto de partida é pacífico (onde o outro não é reduzido a objeto), mas é claro que pode haver conflito (é claro que posso ser tomado como objeto) (SCHMIDT, 1979, p. 214). Helen Fielding também aponta isto de modo bastante claro: “o conhecimento anterior de uma coexistência pacífica leva a uma visão da intersubjetividade que não envolve necessariamente um resultado violento, como na leitura kojèviana de Hegel, uma leitura que na França incluía Lacan” (FIELDING in OLKOWSKI, 1999, p. 195, grifo meu).

Se ficarmos atentos, veremos isso em outras passagens, como estas:

o conflito entre mim e outrem não começa somente quando procuramos pensar outrem, e não desaparece se reintegrarmos o pensamento à consciência não-tética e à vida irrefletida: ele já está ali se procuro viver outrem (...) ( $\mathrm{PhP}$, p. 409, grifo meu); outrem me transforma em objeto e me nega, eu transformo outrem em objeto e o nego, diz-se. Na realidade, o olhar de outrem só me transforma em objeto, e meu olhar só o transforma em objeto se nós dois retirarmos para o fundo se nossa natureza pensante (...) (PhP, p. 414, grifo meu).

Esta condicional, este "se", é fundamental. Lembremos que a Phénoménologie de la Perception nos ensina a primazia da consciência perceptiva: Primeiramente, minha relação com o outro é uma relação perceptiva - não escolho perceber ou não, eu já compreendo corporalmente o que o outro me esboça. Mas se se pôde dizer de um “poder corporal”, isto se deu a partir de uma sedimentação do corpo - é preciso pressupor esta esfera sedimentada para qualquer ato particular. É do mesmo modo que devemos entender a intersubjetividade: há um mundo partilhado, pressuposto, que já está em jogo, de onde se pode entrar em conflito com o outro.

Mas não se pode negar que existe um certo tipo de solipsismo vivido. Merleau-Ponty chega a dizer que o outro é um “irmão menor” (PhP, p. 495). Isto poderia nos levar a pensar num conflito com outro a partir do momento em que surge o cogito. É por isso que MerleauPonty nos dizia que a intersubjetividade deveria lembrar o mundo infantil e não ser como ele. Como nos diz Waelhens (1968, p. 245): “a luta das consciências só começa com o cogito, mas 
ela precisa, para se instaurar, da prova de uma comunidade vivida”. Mas Merleau-Ponty dizia também o contrário: eu e outrem podemos enlaçarmo-nos (PhP, p. 495).

Para entendermos isto, insistamos que há uma primazia da consciência perceptiva: o outro se apresenta a mim, primeiramente, enquanto um comportamento e não enquanto um outro cogito. Num segundo momento, como vimos, este sujeito não pode ser reduzido a um simples comportamento, porque não posso viver aquilo que outrem vive. Mas ambos os momentos são parte de um único fenômeno na Phénoménologie de la Perception, como destaca muito bem Moutinho (2006, p. 330):

encontro-me situado no mundo, em um presente vivo — e, aqui, eu e outrem nos encontramos —, mas essa situação não é um dado para mim, não é estranha para mim, porque eu sou dado não apenas ao mundo, mas também a mim mesmo, de modo que não me reduzo ao que outrem percebe de mim; inversamente, esse fundo solipsista não me permite fechar-me em mim mesmo e constatar-me em plena transparência, em uma adequação perfeita; ao contrário, estou irremediavelmente engajado em uma situação, de modo que só posso apreender-me por intermédio do mundo; por isso, não sou um ego cogito, uma coincidência comigo mesmo. Restava daqui, portanto, uma pluralidade de Eus, mas Eus irremediavelmente situados no mundo e, portanto, em coexistência ${ }^{21}$.

Percebamos como há uma mudança bem sutil, mas bastante significativa aqui, a meu ver. Se na Phénoménologie de la Perception é o conflito que é “possível” numa relação de coexistência, doravante, é “colocar-se acima da luta” ou de “renunciar à luta” que é algo “possível” (Sorb, p. 107). Ou ainda, outrem é reduzido a objeto a mim a tal ponto que “é preciso estabelecer uma comunicação que não condene o outro a se confrontar com a imagem que eu tenho dele” (Sorb, p. 231, grifo meu).

\footnotetext{
${ }^{21}$ Esta coexistência, na verdade, lembra bastante uma tese recente de Daniel Stern sobre o mundo infantil. Diferentemente de Freud, Wallon ou Lacan, Stern diz que a criança, desde o seu nascimento, tem um certo saber de si, ao afirmar que ela tem um "senso" de si (sense of self). Não se trata aqui de uma teoria cognitiva, mas de uma descrição do modo como a criança toma a consciência de que é um indivíduo diante de outros (STERN, 1985, p. 79). A proximidade com Merleau-Ponty está, a meu ver, na afirmação de que, este saber, pré-reflexivo, não é o foco da criança em seu desenvolvimento, mas, sim, uma relação mútua, de "ser-com" o outro. Isto torna possível, ao psicólogo, afirmar uma relação de reciprocidade com o outro, mesmo reconhecendo que a criança tem aquele "senso" de si (STERN, 1985, p. 136). A importância disto, segundo Frie, por exemplo, é a possibilidade de se afirmar um saber pré-reflexivo, uma diferenciação entre eu e outrem, mas numa relação de reciprocidade, sem reduzir a intersubjetividade a uma pura ilusão. Isto é possível porque "este modelo do si [of the self], portanto, reconhece a facticidade da subjetividade individual, mas rejeita essencialmente a idéia de separção como um fim em si mesmo. Ao invés de tomar a autonomia do sujeito como um objetivo, assume-se que o indivíduo existe no contexto de contínua relação com os outros” (FRIE, 1997, p. 67). Esta passagem de Merleau-Ponty, a meu ver, confirma esta convergência: “sem reciprocidade, não há alter Ego (...)” (PhP, p. 410).
} 
Ora, se na Phénoménologie de la Perception, o outro é para mim, no fundo, um eu que co-existe comigo, porque somos consagrados ao mundo, com o “estádio do espelho”, outrem passa a ser quem sustenta minha posição de imagem. Trata-se de uma dependência constitutiva do sujeito em relação ao outro. Sendo assim, o conflito é instaurado no momento mesmo em que a criança se assume como Eu diante do outro:

pois há inevitavelmente conflito entre eu, tal como me sinto, e eu, tal como me vejo ou tal que os outros me vêem. A imagem especular vai ser, entre outras coisas, a primeira ocasião para a agressividade para com o outro se manifestar. (...) A aquisição da imagem especular interessa então, não somente nas relações de conhecimento, mas também nas relações de ser entre o mundo, com o outro (RAE, p. 204).

O fundamental é destacarmos que surge uma nova forma de se pensar a relação com outrem, porque se deve ter em mente um contraste entre “eu como objeto” e “eu como consciência vivida” (Sorb, p. 96).

Mas é interessante notarmos que Merleau-Ponty insiste, nestes cursos de Sorbonne, em dizer também de uma certa reciprocidade: há uma síntese de co-existência com o outro (RAE, p. 208), ou ainda, de um certo “(...) tipo original de relação com outro (as relações de ‘reciprocidade')” (RAE, p. 208). Chega a dizer de uma encarnação (incarnation) (RAE, p. 181).

Afirmar uma “coexistência”, uma “relação de reciprocidade”, uma “encarnação”, parece contradizer com a problemática lacaniana, retomando o problema da co-existência como uma relação mais profunda na relação com o outro (Sorb, p. 547). O paradoxo então é compreendermos como é possível afirmar que há uma relação de oposição e de coexistência, sem que uma fundamente a outra: ambas se dão de um só golpe. Poderíamos até colocar este impasse nesta analogia que Schmidt (1985, p. 91) nos aponta na contemporaneidade de Merleau-Ponty: “Sartre via o olhar como o 'olhar que mata’; em Valéry, o entrecruzamento de olhares iniciava um processo de 'simultaneidade, limitação recíproca' que produz ‘descentramento', não uma ‘aniquilação'. Sartre conhecia somente 'uma rivalidade entre eu- 
outro’; em Valéry nós temos ‘co-funções’ do eu e do outro”. O que podemos pensar disso? O que está em jogo aqui?

\section{8) Breves apontamentos: uma "situação comum"}

Certamente, era de se esperar que eu afirmasse aqui, entre outras coisas, que houve uma mudança na filosofia de Merleau-Ponty devido ao problema da imagem corporal. Mas não é este o ponto decisivo ao filósofo. O que fiz aqui foi uma estratégia para tentar mostrar como o conflito abre um campo interessante para pensarmos a relação com o outro.

Na verdade, no curso de Sorbonne, as pesquisas de Merleau-Ponty já eram direcionadas a pensar no conflito com o outro. Como Saint Aubert (2004, p. 52) afirma num texto recente: o principal tema deste curso de Merleau-Ponty é o conflito. Aliás, Aubert faz uma leitura muito original da obra merleau-pontyana a partir da idéia de um empiétement (“invasão”) em operação no pensamento do filósofo. Não é exatamente nisto que nos debruçamos, mas Aubert nos confirma uma grande "ampliação" da filosofia merleaupontyana: “o reconhecimento do lugar da violência [do conflito, da luta etc.] é em MerleauPonty sua principal aquisição, a novidade mais flagrante de sua escritura nos anos imediatos ao pós-guerra” (AUBERT, 2004, p. 50) 22 .

De fato, esta questão já se desenhava nas obras políticas do filósofo. Aliás, o problema da imagem corporal deve se refletir nas relações sociais seguindo a própria “letra” do filósofo: é preciso buscar, desde os conflitos infantis, o anúncio do primeiro esboço do drama humano

\footnotetext{
${ }^{22}$ Outros, como Whiteside (1988, pp. 88-87), arriscam “localizar” onde surge esta nova "aquisição”: “a dialética hegeliana do senhor e do escravo é o centro da teoria política de Merleau-Ponty, dando-lhe a chave que ele precisava para decodificar a vida intersubjetiva. (...) De fato, a dialética do senhor e do escravo serve a MerleauPonty como o caso paradigmal da violência em si mesma, porque Hegel revela uma estrutura comum de objetivação para toda forma de violência”.
} 
que as ações e as obras dos adultos realizam (HT, p. 178). Ora, isto não é algo para estranharmos, desde que compreendamos que, segundo Merleau-Ponty,

(...) a psicanálise nasceu como a expressão de uma sociedade ocidental nessas ou naquelas condições históricas. A psicanálise pode ser considerada o retrato dessa sociedade. Mas, reciprocamente, os mecanismos psicológicos que a psicanálise descreve intervêm no funcionamento social, sem por isso se reduzirem a fatos 'individuais' (Sorb, p. 382).

É certo que, nas suas obras política, Merleau-Ponty não abandona os problemas da Phénoménologie de la Perception. O que me parece é que o filósofo aprofunda o problema da relação com o outro de um modo bastante interessante, ao manter o tema da coexistência, trazendo ao seu bojo a questão do conflito. Mas, como nos diz Aubert (2005, p. 122), o conflito em Merleau-Ponty não é pensado como uma oposição entre positivo e negativo, assim como professava a tradição kojèviana. Diferentemente, Merleau-Ponty procurou encontrar uma "situação comum”, que unisse a violência e a coexistência ao mesmo tempo. Eslin (1982, p. 8) também nos indica isto: “a obra política de Merleau-Ponty permanece formadora pelo modo que ela quer manter ao mesmo tempo coexistência e violência de encontro a todo idealismo”. Também Whiteside (1988, p. 83): Merleau-Ponty “(...) percebe que se deve contar com o misto do conflito e do diálogo que caracteriza a existência humana”. Hyppolite (1961, p. 240) coloca isto em termo de uma “dialética”: “é por isto que esta existência é dialética, na medida em que ela é uma retomada e um ultrapassamento de uma situação anterior, na medida em que na coexistência ela é conflito e conciliação”. Esta posição do filósofo, de tomar a violência e a coexietência, parece aproximá-lo de Machiavel, como testemunha ainda Eslin (1982, p. 17):

a semelhança que se tem de Merleau-Ponty e Machiavel é que nem um nem outro velam a face diante da violência, imediata, dada, da política (...) [buscando] a coexistência entre os homens, entre os príncipes e os sujeitos, o lugar entre ação política, violência e coexistência. Tem em comum, um e outro, na exata articulação da coexistência pública e da violência, aquilo que será a posição também de Lévinas (eu sou sempre violento ao olhar do outro), mas esta articulação Lévinas não a trata na política, ele a trata como uma relação ética entre o homem e o homem. 
Trata-se assim de apontar uma idéia de uma "situação comum” que gostaria de, ao menos, indicar por fim:

o problema político e social: problema da vida com outros e da violência. Vida a dois: reciprocidade é possível? E se não, há violência, i.e., um dos dois perde autonomia, é seduzido, o outro torna destino para ele. Isto é superado pela vida comum, empreendimento comum, criação de uma totalidade onde cada um vive: decide-se em comum (MERLEAU-PONTY apud AUBERT, 2004, p. 68).

É sabido que a temática filosófica de Merleau-Ponty parece se deslocar aos poucos ao problema do engajamento político pós Phénoménologie de la Perception por um motivo bem concreto, como testemunha Corcuff (2001, p. 209): “(...) o pensamento político de MerleauPonty é uma confrontação com a atualidade política de seu tempo, com as tarefas práticas e as tomadas de posição que ela requer, muitas vezes na urgência, com o risco de se enganar”. Ora, desde o ano de 1945 o filósofo já escrevia textos como La Guerre a eu Lieu, denunciando uma certa filosofia otimista na França, “(...) que reduzia a sociedade humana a uma soma de consciências sempre consentida à paz e à felicidade (...)” (GL, p.169). A ocupação nazista levava, pela primeira vez, não só a constatar o conflito com o outro, mas a “assumir a vida social” (GL, p. 175) ${ }^{23}$. Aliás, para Eslin, a “descoberta” da contingência em Merleau-Ponty se emparelhava agora com a "violência” (devido à “descoberta” da fragilidade da liberdade e da razão ou pela própria violência ter aberto os olhos dos intelectuais (ESLIN, 1982, pp. 10-11)).

Certamente, o ano de 1945 era um ano marcante, não só pela defesa da Phénoménologie de la Perception, como um ano que não poderia ser um entre os outros, porque levou os intelectuais a assumirem que não são os mesmos e a ultrapassarem o dilema entre teoria e prática, assim como a se engajarem numa situação comum (GL, pp. 183-184) ${ }^{24}$. Para Whiteside (1988, p. 3), por exemplo, isto é determinante: “fazer a política 'pensável’ era o problema mais urgente face à filosofia pós-guerra”. Doravante,

\footnotetext{
23 "É primeiramente a experiência da guerra que nutre o questionamento político de Merleau-Ponty" (CORCUFF, 2001, P. 210).

${ }^{24}$ Uma testemunha disto é o texto de Sartre: Merleau-Ponty Vivant.
} 
a descrição do sentido da teoria existencial demanda vir à tona a descrição de um mundo marcado por injustiça, violência, insatisfação social e guerra. Certamente Merleau-Ponty não contenta que estes aspectos da experiência sejam imutáveis ou desejáveis, mas ele rejeita as teorias da consciência que implicitamente minimizam sua seriedade ou intratabilidade. Ele exige uma noção de ação política que, como na história hegeliana do senhor e do escravo, descreva a prevalência da violência nas relações humanas (WHITESIDE, 1988, PP. 99-100).

Em 1946, por exemplo, em L'Existentialisme chez Hegel, o problema da coexistência aparecia então como algo marcante, imbricado com o problema do conflito: “a consciência do conflito só é possível por uma relação recíproca e de uma humanidade que nos é comum. Nós não negamos um ao outro senão reconhecendo um no outro como consciências” (EH, p. 85). Ora, não se trata mais, como na Phénoménologie de la Perception, de uma coexistência de onde é possível o conflito, mas do conflito no nível da coexistência. O que Merleau-Ponty propunha aqui não era mais um "ponto de partida” numa situação comum conflituosa, mas que só é possivel numa coexistência: eu não vivo para morrer assim como não vivo sozinho, mas para viver com os outros (EH, p. 87).

Este paradoxo do engajamento político se revelava ao filósofo de um modo bastante original. Por um lado, “a única experiência que me aproxima de uma consciência autêntica da morte, é a experiência de outro, pois sob seu olhar eu só sou uma coisa, como ele é apenas um pedaço do mundo sob meu próprio olhar” (EH, p. 85). Percebamos a diferença aqui com a Phénoménologie de la Perception: agora ele afirma que "eu sou uma coisa” sob o olhar do outro e não que “eu posso ser”. Por outro lado, há uma situação comum, uma situação de coexistência nesta mesma lógica: "se eu sou negação, seguindo até o fim no que implica esta negação universal, eu verei ela se negar e se transformar em coexistência” (EH, p. 85).

Neste mesmo ano afirma:

o otimismo democrático admite que, num Estado onde os direitos do homem são garantidos, nenhuma liberdade não invade [empiète] mais sobre as outras liberdades e a coexistência dos homens como sujeitos autônomos e racionais se encontram garantida. Isto é supor que a violência não faz na história humana senão uma aparição episódica, que as relações econômicas em particular tendem por si a realizarem a justiça e a harmonia e, enfim, que a estrutura do mundo natural e humano é racional. Nós sabemos hoje que a igualdade formal dos direitos e a liberdade política mascaram as relações de força (...) (AM, pp. 124-125). 
Esta idéia é abundante nestes textos imediatamente após a Phénoménologie de la Perception. Um outro exemplo: “entre o poder e seus sujeitos, entre o eu e o outro, não há um terreno onde cessa a rivalidade” (NM, pp. 267-268). Logo à frente ele afirma: “há um circuito entre eu e o outro, uma Comunhão (...)” (NM, p. 268). Sua leitura de Machiavel o levava a pensar a política sob o signo de uma coexistência e de uma violência:

se denominamos humanismo uma filosofia do homem interior que não encontra nenhuma dificuldade de princípio nas relações com os outros, nenhuma opacidade no funcionamento social, e coloca a cultura política por uma exortação moral, então Machiavel não é humanista. Mas se denominamos humanismo uma filosofia que confronta como um problema a relação do homem como o homem e a constituição entre eles de uma situação e de uma história que lhes sejam comuns, seria preciso então dizer que Machiavel formulou algumas condições de todo humanismo sério (NM, pp. 282-283).

Na obra Humanisme et Terreur ele afirmava categoricamente:

'cada consciência, diz-se, busca a morte de outra' [Hegel]. (...) Mas a consciência não pode nada sem seu corpo e não pode fazer nada sobre os outros senão agindo por seu corpo. Ela não os reduz em escravos senão fazendo da natureza um anexo de seu corpo, se apropriando e os fazendo como instrumentos do seu poder. A história é então essencialmente luta - luta do mestre e do escravo, luta de classes -, e isto por uma necessidade da condição humana e em razão do paradoxo fundamental do homem ser indivisamente consciência encarnada, cada qual não pode se afirmar senão reduzindo os outros em objetos (HT, p. 210).

Mas páginas depois, ele diz que o fato de ter nascido numa sociedade particular, numa classe particular, nos coloca numa "situação comum” (HT, p. 119) ${ }^{25}$, num engajamento comum, onde minha vida particular se confundiria com a totalidade das ações “(...) deliberadas ou não, que se exercem sobre os outros e sobre o mundo; há, não uma pluralidade de sujeitos, mas uma intersubjetividade (...)” (HT, p. 118). Aliás, a história só tem um sentido para o filósofo, se ela tem uma lógica da “coexistência humana” (HT, p. 166).

Enfim, não podemos agora retomar a trajetória do engajamento político do filósofo, mas poderíamos arquitetar este problema deste modo: é possível dizer, ao mesmo tempo, de uma situação conflituosa, assim como uma situação de coexistência, sem que uma exclua a outra situação. Para Whiteside (1988, p. 106), isto é um fato a Merleau-Ponty:

${ }^{25}$ É certo que Merleau-Ponty dizia de uma “situação comum” também na Phénoménologie de la Perception (PhP, p. 409). Mas, neste caso, tratava-se de uma situação projetada, possível, diante de um conflito possível com o outro. Aqui, este conflito já não está mais no reino do possível - é um fato. 
a política é um domínio onde difícies escolhas devem ser tomadas, envolvendo níveis de respeito e níveis de violência. A filosofia deveria por isto se ajustar para fazer possível um modo de pensar o que a política demanda. (...) [Neste caso,] a análise merleau-pontyana do sentido do coletivo conclui que a relação do corpo preceptivo com o mundo e com o outro implica uma constante tensão entre comunicação e violência (p. 134).

Sabemos que na Phénoménologie de la Perception, Merleau-Ponty nos dizia de um modo de relação que tinha suas raízes heideggerianas: “um certo modo de Mit-Sein” (PhP, p. 518). Ora, ser-com o outro era fundamental na sua tese: não haveria barreiras entre meu corpo e o corpo do outro, "nós estamos ligados ao mundo e aos outros numa confusão inextrincável” (PhP, p. 518). Existir é fundamentalmente co-existir com o outro: há uma comunhão corporal. O conflito aparecia assim como algo possível, como um modo de ser possivel com o outro. Já ao estudarmos a imagem corporal, nos cursos de Sorbonne, era o conflito que estava em jogo: é inevitável que eu reduza o outro a objeto, porque só assim poderia me assumir como sujeito diante do outro. Mas esta inversão não é tão radical como aparentemente se revela.

Na verdade, como nos diz Aubert (2004, p. 130), “não se trata mais de escolher entre um fundo de Mitsein e um fundo de conflito, a violência não precede estritamente a coexistência, nem o inverso (...)”. Aliás, Aubert é bastante sugestivo em sua análise: o que parece ser decisivo não é ter posto a violência sob o signo da relação com o outro, porque “a questão não é escolher ou não a violência, mas de revelar nela um apelo à coexistência. O autor de Sens et non-sens se interessa menos no caráter destrutivo da violência que na sua orientação possível (...)” (AUBERT, 2004, p. 52). O mesmo já dizia Waelhens (1968, p. 350): “não é a violência que é preciso discutir, mas seu sentido e suas perspectivas, da possibilidade que nos resta para superar certas formas, não por agora, mas depois de amanhã”. Tomemos como apoio este trecho de Humanisme et Terreur:

nós não temos que escolher entre a pureza e a violência, mas entre diferentes modos de violência. A violência é nosso quinhão na medida em que somos encarnados. (...) O que conta e o que é preciso discutir não é a violência, mas seu sentido e seu futuro. É a da lei da ação humana transpor o presente em direção ao futuro e o eu versus o outro. Esta intrusão não é somente um fato da vida política, ela se produz na vida privada. (...) Se nós condenamos toda violência, tomamos um lugar fora do domínio onde há justiça e injustiça, difamamos o mundo e a humanidade - difama hipócrita porque aquele que a pronuncia, desde o momento que vive, já aceitou a regra do jogo (HT, pp. 117-118). 
Sendo assim, ao estudarmos a imagem corporal, nos perguntávamos: por que a imagem corporal está agora em operação no esquema corporal, diferentemente do que acontecia na Phénoménologie de la Perception? Penso que após esta obra, não se trata mais de escolher entre o Mit-Sein e o jogo Herrschaft und Knechtschaft ${ }^{26}$. Ao apontarmos os problemas políticos de sua época, não há mais primazia: ambas as relações são primordiais. Eu e outrem estamos numa “situação comum”.

É um fato que vivo em conflito com o outro. É assim que, nos cursos de Sorbonne, especialmente na análise que acompanhamos da "imagem corporal”, o conflito figurava como uma situação inevitável na relação com o outro, principalmente ao assumir que esta imagem corporal entra em operação no esquema corporal da criança e, conseqüentemente, em relação ao outro. Não há mais sentido em dizer que o conflito é possível: ele é inevitável. Não se trata, entretanto, de buscar compreender "as condições de possibilidade” da existência do outro para uma consciência, mas “(...) da modalidade concreta de nossas relações efetivas a nós memos e ao outro” (AUBERT, 2004, p. 315). Aliás, em L'Existentialisme chez Hegel, Merleau-Ponty chega a criticar o Mit-Sein heidegerriano por negligenciar o fato do conflito com o outro: “pode-se mesmo dizer que o que falta em Heidegger não é a historicidade, é, ao contrário, a afirmação do indivíduo: ele não diz desta luta das consciências e desta oposição das liberdades sem o qual a coexistência recai ao anonimato e à banalidade cotidiana” (EH, pp. $86-87)^{27}$

Mas é também um fato que coexisto com o outro. O reconhecimento do conflito não excluía, no curso La Conscience et l'Acquisition de Langage, dizer que a criança coexiste com o outro de um modo profundo. Nem de afirmar que há uma “(...) situação comum dos

\footnotetext{
${ }^{26}$ Recentemente, Frie parece defender uma tese muita próxima desta posição de Merleau-Ponty, partindo das análises de Sartre e Lacan, por um lado, e Binswanger e Habermas por outro: "declarar que há possibilidade de reciprocidade na comunicação não significa sugerir que a tensão entre os indivíduos irá cessar (...)” (FRIE, 1997, p. 203).

${ }^{27}$ Poderíamos nos perguntar se esta passagem não é também uma auto-crítica, ao afirmar, na Phénoménologie de la Perception, que a relação com o outro se daria como "um certo modo de Mit-Sein" (PhP, p. 518).
} 
homens, sua vontade de coexistirem e de se reconhecerem” (Sorb, p. 86) - algo que, na verdade, já estava presente na Phénoménologie de la Perception.

Esta situação comum era fundamental ao filósofo na construção de uma coexistência com o outro, mesmo assumindo a violencia do homem: "desde que eu exista, ajo, seduzo, invado sobre a liberdade de outro” (MERLEAU-PONTY apud AUBERT, 2004, p. 132). Não podemos analisar esta passagem mais de perto, mas isto indica, sem dúvida, que aquilo que era inicialmente apresentado como um obstáculo maior à relação eu-outro, o inevitável conflito, se torna aqui o signo de que a coexistência existe e que ela "invade" as relações entre os homens, pois

violência e coexistência são então simultâneas, inerentes à existência de um homem que não se torna livre senão as unindo; elas são as duas orientações não somente possíveis mas necessárias de um só e mesmo lugar, o lugar da liberdade que é a invasão. A invasão mostra assim este estranho poder de instituir o conflito que me opõe ao outro e de instituir a situação comum na qual nos passamos um no outro (AUBERT, 2004, p. 132). 


\section{Conclusão - Em torno do corpo próprio e sua imagem...}

Meu objetido neste trabalho era compreender a noção de corpo próprio apresentada por Merleau-Ponty em seus primeiros trabalhos, assim como um desdobramento interessante deste conceito: a imagem corporal. Quanto ao corpo próprio, pude mostrar que se tratava de um conceito fundamental no arcabouço conceitual da fenomenologia. No primeiro capítulo, apontei como o filósofo partia de uma análise concreta da subjetividade e que nos levou a pensar o corpo próprio como sujeito de percepção. No segundo capítulo, era necessário descrever como este sujeito se relaciona com o mundo. Pudemos vislumbrar como MerleauPonty descreve este sujeito numa abertura com o mundo: no comportamento voltado ao possível.

Logo depois, pudemos vislumbrar dois outros conceitos-chaves na fenomenologia: o poder corporal e o saber corporal. No primeiro caso, um poder de abertura, mas que se fundamentava num saber sedimentado do corpo: eu só posso agir contando com meu passado. Pudemos assim esboçar uma "generalidade do corpo” a partir da qual era possível dizer de uma "história pessoal”. Em vários casos, pudemos verificar isto; em especial, na descrição do hábito corporal, do corpo expressivo e do corpo libidinal.

Com isto em mãos, uma questão foi apontada: se se descreve um corpo aberto ao mundo, poderíamos dizer do mesmo modo de uma consciência de si? Para respondermos isto, verificamos como Merleau-Ponty nos mostrava como agimos enquanto uma unidade corporal. Pudemos então descrever o esquema corporal e verificar, num caso concreto, do membro fantasma, como esta unidade se manifestava. Ainda neste capítulo, verificamos que a tomada de consciência desta unidade corporal não nos levava a dizer de uma consciência de si. Esta 
esfera aparece na fenomenologia merleau-pontyana, na impossibilidade do sujeito ter plena determinação de si: há uma fé no mundo que não nos possibilita diferenciar, no momento da percepção, uma percepção verdadeira de uma ilusão. Mas vimos também que o sujeito é capaz de se corrigir num contato de si a si que evidência um certo tipo de consciência de si em exercício. Mas isto não nos levou a dizer de uma plena determinação de si. Ao contrário, a uma consciência que se transgride a todo o momento. Além disso, nos mostrou que há uma generalidade da subjetividade que integra a experiência do sujeito.

Entretanto, como vimos, só é possível a este sujeito ter consciência de si quando realiza um ato. Isto significa que Merleau-Ponty une o ser no mundo com o ser para si: ter experiência é comunicar um sujeito finito, mas que sabe de si, como um ser opaco, de onde se emerge e onde permanece engajado. Chegamos aí numa conclusão importante: é o corpo próprio, enquanto sujeito encarnado, que torna manifesto esta presença de si a si, numa situação dada, num campo de presença.

Mas ficava uma questão em aberto: Merleau-Ponty não nos apontava um momento específico da tomada de consciência da unidade corporal assim como não nos indicava as conseqüências desta assunção. Já nos cursos de Sorbonne, onde Merleau-Ponty analisa vários casos da psicologia infantil e da psicanálise, o estudo do estádio do espelho indica a origem desta tomada de consciência a partir da imagem corporal.

Pudemos acompanhar então como a inclusão desta imagem no esquema corporal ampliava a problemática da relação com o outro. Se por um lado a Phénoménologie de la Perception indicava uma intersubjetividade a partir da consciência perceptiva, com o problema do estádio do espelho, a imaginação também deveria estar em operação nesta relação. Isto trazia consigo uma conseqüência: uma inevitável relação de conflito com o outro. Ora, na Phénoménologie de la Perception, o conflito com o outro só aparecia como algo possível, como um modo possível de se relacionar com o outro. Haveria antes um "lugar 
pacífico”, um meio onde meu corpo e o corpo do outros estariam intricados de modo inalienável. Entretanto, doravante, o conflito com o outro não poderia mais ser tomado enquanto algo possível, mas como um fato presente em toda relação.

Como vimos, o curioso é que Merleau-Ponty não escolhe mais um ponto de partida: não se trata mais de escolher entre um "lugar pacífico" e um conflito com o outro. Tanto a indicação ser-com o mundo heideggeriana quanto o conflito no jogo de olhares de tradição kojèviana (levada a cabo, por exemplo, por Sartre e Lacan) figuravam num mesmo nível. Entretanto, para Merleau-Ponty, o importante passa a ser uma "situação comum” que a obra política do filósofo já desenhava. O problema da imagem corporal operou assim numa estratégia para desdobrar um problema que já estava sendo articulado nos trabalhos posteriores à Phénoménologie de la Perception. Mas este caso em especial, a meu ver, pode indicar as conseqüências de se pensar na relação com o outro a partir do conflito: a inevitável relação de redução a objeto sob o olhar do outro, que só era possível num meio onde o outro se figura como ser-com. Na verdade, Merleau-Ponty encontrou um modo de articular um problema que, em suas análises políticas, já se despontava.

Acompanhando a interpretação do filósofo do estádio do espelho, pudemos compreender como este conflito era inevitável e por que o era. Entretanto, seria também interessante, sem dúvida alguma, retomarmos esta problemática nos textos sobre o engajamento político do filósofo para entendermos melhor o porquê deste conflito. Não bastaria simplesmente dizermos que isto é um fato. Seria preciso retomar sistematicamente este problema em seus vários níveis descritos pelo filósofo. Pude esboçar isto a grosso modo, no nível da imagem corporal, mas algo mais abrangente me exigiria começar um outro trabalho... 


\section{Bibliografia}

ALAIN. Éléments de Philosophie. Paris: Gallimard, 1941.

AUBERT, Emmanuel de Saint. Du Lien des Êtres aux Éléments de l'Être-Merleau-Ponty au tournant des Années 1945-1951. Paris: Vrin, 2004.

Le Scénario Cartésien - Recherches sur la Formation et la Cohérence de l'Intention Philosophique de Merleau-Ponty. Paris: Vrin, 2005.

.Vers une Ontologie Indirecte - Sources et Enjeux Critiques de l'Appel à l'Ontologie chez Merleau-Ponty. Paris: Vrin, 2006.

BAAS, Bernard. De la Chose à l'Objet - Jacques Lacan et la Traversée de la Phénoménologie. Leuven: Peeters; Vrin, 1998.

BARBARAS, Renaud. De l'Être du Phénomène - Sur l'Ontologie de Merleau-Ponty. Paris: Éditons Jérôme Millon, 2001a.

- Merleau-Ponty et la Psychologie de la Forme in Les Études Philosophiques Merleau-Ponty - Le Philosophie et les Sciences Humaines. Paris : PUF, avril, juin 2001b n. 2.

De la Phénoménologie du Corps à l'Ontologie de la Chair in GODDARD, JeanChristophe (org.). Le Corps. Paris: Vrin, 2005a.

. A Phenomenology of Life in CARMEAN; HANSEN. The Cambridge Companion to Merleau-Ponty. New York: Cambridge University Press, 2005b.

Le Tournant de l'Experience - Recherches sur la Philosophie de Merleau-Ponty. Paris: Vrin, 1998.

BENJAMIN, Jessica. Bonds of Love: Psychoanalysis, Feminism, and the Problem of Domination. London : Virago, 1990.

BIMBENET, Étienne. Merleau-Ponty et le projet d'une science de l'homme sans l'homme in Les Études Philosophiques - Merleau-Ponty - Le Philosophie et les Sciences Humaines. Paris : PUF, avril, juin 2001 n.2.

BIRMAN, Joel. Pensamento freudiano e a constituição do saber psicanalítico. Tese de doutorado apresentada ao Departamento de Filosofia da Universidade de São Paulo, sob a orientação do Prof. Luiz Roberto Salinas Fortes, 1984.

BOOTHBY, Richard. Freud as Philosopher - Metapychology after Lacan. New York: Routledge, 2001. 
BUCCI. Eugênio; KEHL, Maria Rita. Videologias. São Paulo: Boitempo, 2004.

BUTLER, Judith. Sexual Ideology and Phenomenological Description - A Feminist Critique of Merleau-Ponty's Phenomenology of Perception in AlLLEN, Jeffner; YOUNG, Iris Marion. Thinking Muse - Feminism and Modern French Philophy. Bloomington and Indianapolis: Indiana University Press, 1989.

. Subjects of Desire - Hegelian Reflections in Twentieth-Century France. New York:

Columbia University Press, 1999.

BUYTENDIJK, F.J.J. L'homme et l'animal - essai de psychologie compare. Traduit de l’allemand par Remi Laureillard. Paris: Gallimard, 1965.

CANGUILHEM, Georges. O normal e o Patológico. Tradução de Maria Barrocas. Rio de Janeiro: Forense Universitária, 2002.

CHAUI, Marilena. Experiência do pensamento - ensaios sobre a obra de Merleau-Ponty. São Paulo: Martins Fontes, 2002.

. Maurice Merleau-Ponty e a crítica ao humanismo. Tese de mestrado apresentada ao

Departamento de Filosofia da Universidade de São Paulo, sob a orientação do Prof. José Arthur Giannotti. São Paulo, 1967.

CORCUFF, Philippe. Merleau-Ponty ou l'analisy politique au défi de l'inquiétude machiavélienne in Les Études Philosophiques - Merleau-Ponty - Le Philosophie et les Sciences Humaines. Paris : PUF, avril, juin 2001 n. 2.

DESCARTES, René. Oeuvres Choisies de Descartes - Métaphysique et Physique. Paris: Garnier Frères, 1950.

DESCOMBES, Vincent. Le Même et l'Autre - Quarante-cinq ans de Philosophie Française (1933-1978). Paris: Éditions de Minuit, 1993.

DEWS, Peter. O Eclipse da Coincidência: Lacan, Merleau-Ponty e os Equívocos de Žižek em sua leitura de Schelling in DUNKER, Christian Ingo Lenz; PRADO, José Luiz Aidar (org). Žižek Crítico - Política e Psicanálise na Era do Multiculturalismo. São Paulo: Hacker, 2005.

DILLON, M. C. (org). Merleau-Ponty Vivant. New York: Suny, 1991.

DUNKER, Christian Ingo Lenz. O cálculo Neurótico do Gozo. São Paulo: Escuta, 2002. - O nascimento do sujeito in Revista Mente \& Cérebro: A mente do Bebê - O fascinante Processo de Formação do Cérebro e da Personalidade Vol. 2. São Paulo: Duetto, 2006.

ELLIS, Willis D. A source book of Gestalt Psychology. New York: The Humanities Press Inc., 1955. 
ESLIN, Jean-Claude. Critique de l'Humanisme Vertueux in Esprit n. 6. Paris, juin 1982.

FERRAZ, Marcus Sacrini A. O Transcendental e o Existente em Merleau-Ponty. São Paulo: Humanitas; Fapesp, 2006.

FINK, Eugen. De la Phénoménologie. Traduit par Didier Frank. Paris: Les Editions de Minuit, 1974.

FREUD, Sigmund. La Interpretación de los Sueňos vol. I e II. Traducción del Luis LópezBallesteros y de Torres. Buenos Aires: Santiago Rueda, 1953a. . Introducción a la psicoanálisis vol. II . Traducción del Luis López-Ballesteros y de Torres. Buenos Aires: Santiago Rueda, 1953b. . Nuevas Aportaciones a la Psicoanálisis y Otros Ensayos. Traducción del Luis López-Ballesteros y de Torres. Buenos Aires: Santiago Rueda, 1953c. . Psicologia de las Masas y Análisis del Yo. Traducción del Luis López-Ballesteros y de Torres. Buenos Aires: Santiago Rueda, 1953d. . Totem y Tabu. Traducción del Luis López-Ballesteros y de Torres. Buenos Aires: Santiago Rueda, 1953e. . Una Teoría Sexual y Otros Ensayos. Traducción del Luis López-Ballesteros y de Torres. Buenos Aires: Santiago Rueda, 1952.

FRIE, Roger. Subjectivity and Intersubjectivity in Modern Philosophy and Psychoanalysis - A Study of Sartre, Binswanger, Lacan, and Habermas. New York: Rowman \& Littlefield Publishers, 1997.

FURLAN, Reinaldo. Freud, Politzer, Merleau-Ponty in Psicologia USP - Vol. 10, n. 2. São Paulo: USP-IP, 1999. . A noção de Consciência n'A Estrutura do Comportamento (Merleau-Ponty) in Psicologia USP - Vol. 12, n. 1. São Paulo: USP-IP, 2001.

GERAETS, Theodore F. Vers une Nouvelle Philosophie Transcendantale - La Genèse de la Philosophie de Maurice Merleau-Ponty jusqu'à la Phénoménologie de la Perception. La Haye : Martinus Nijhoff, 1971.

GOETHE, J. W. Doutrina das Cores. Tradução de Marco Giannoti. São Paulo: Nova Alexandria, 1996.

GOLDSTEIN, Kurt. The Organism - a holistic approach to biology derived from pathological data in man. New York: American Book Company, 1939. . Human Nature in the Light of Psychopathology. New York: Schocken Books, 1971. 
GONÇALVES, Anderson; MORATO, Débora; MOUTINHO, Damon; VIEIRA, Paulo; BRANDÃO, Rodrigo (org.). Questões de Filosofia Contemporânea. São Paulo: Discurso Editorial; Curitiba: UFPR, 2006.

GREEN, Andre. Du Comportement à la Chair: Itinéraire de Merleau-Ponty in Critique Decembre 1964. Paris: Editions de Minuit, 1964.

GUILLAUME, Paul. L'imitation chez l' enfant. Paris: Alcan, 1925. . La formation des habitudes. Paris: Alcan, 1936. . La psychologie de la forme. Paris:Flammarion, 1937.

HEIDEGGER, Martin. Sein und Zeit. Tübingen: Niemeyer, 2001.

HESNARD, A. L'Oeuvre de Freud et son Importance pour le Monde Moderne. Paris: Payot, 1960.

HUONG, Nguyên Thi Thanh. La Formation des Attitudes Affectives - Essai de Synthèse de Freud et de Wallon. Paris: Vrin, 1976.

HUSSERL, Edmund. La Crise des Sciences Européennes et la Phénoménologie Transcendentale. Traduit de l’allemand et préfacé par Gérard Granel. Paris: Gallimard, 2004.

. Ideen zu einer reinen Phänomenologie und phänomenologischen Philosophie zweiter buch: phänomenologisch untersuchungen zur Konstitution. Haag: Martinus Nijhoff, 1952.

. Idées directrices pour une phénoménologie et une philosophie phénoménologique pures - tome premier: introduction générale a la phénoménologie pure. Traduit de l’allemand por Paul Ricoeur. Paris: Gallimard, 1950.

. Lições para uma Fenomenologia da Consciência Interna do Tempo. Tradução de Pedro Alves. Lisboa: Imprensa Nacional da Moeda, 1994.

. Méditations cartésiennes - Introduction a la Phénoménologie. Traduit de l'allemand par Gabrielle Peiffer et Emmanuel Levinas. Paris: Vrin, 1969.

Recherches Logiques - tomo II - Recherches pour la phénoménologie et la théorie de la connaissance. Traduit de l'allemand par Élie. Paris: Presses Universitaires de France, 1962.

HYPPOLITE, Jean. Sens et Existence dans la Philosophie de Maurice Merleau-Ponty. London: Oxford, 1963.

La Philosophie de Merleau-Ponty in Les Temps Modernes. Paris, 17o. Année, no. Spécial sur Merleau-Ponty, octobre, 1961. 
IRIGARAY, Luce. L'Invisible de la Chair - Lecture de Merleau-Ponty - Le Visible et l'Invisible, "L'Entrelacs - le Chiasme” in Éthique de la Différence Sexuelle. Paris: Les Éditions de Minuit, 1984.

JASPER, Karl. Psicopatologia Geral Vol I. Tradução de Samuel Penna Aarão Reis. São Paulo: Livraria Atheneu, 1973.

JAY, Martin. Downcast Eyes - The Denigration of Vision in Twentieth-Century French Thought. Berkeley and Los Angeles:University of California Press, 1993.

KANT, Immanuel. Crítica da Razão Pura. Tradução para o português de Manuela Pinto dos Santos e Alexandre Fradique Morujão. Lisboa: Fundação Calouste Gulbenkian, 2001. . Kritik der Reinen Vernunft. Leipzig: Felix Gross, 1960. . Kritik der Urteilskraft. Leipzig: Felix Gross, 1960.

KAUfMANN, Pierre. De la Vision Picturale au Désir de Peindre in Critique - Decembre 1964. Paris: Editions de Minuit, 1964.

KATZ, David. Psicologia de la forma (Gestaltpsychologie). Traducción del alemán por el José M. Sacristán. Madrid: Espasa-Calpe, 1967.

KOFFKA, Kurt. The Growth of the Mind. Translated by Robert Morris Ogden. New York: Harcourt, 1928. . Principles of Gestalt Psychology. London: Routledge \& Kegan Paul Limited, 1955.

KÖHLER, Wolfgang. Köhler. Organizado por Arno Engelmann. Tradução de José Severo Pereira. São Paulo: Ática, 1978.

. Gestalt Psychology - An introduction to new concepts in Modern Psychology. New York: Mentor Books, 1947. . The Mentality of Apes. Transleted by Ella Winter. New York: Vintage Books, 1959. . The place of value in a world of facts. New York: Liveright Publishing Corporation, 1938.

KOJÈVE, Alexandre. Introduction à la Lecture de Hegel. Paris: Gallimard, 2005.

LACAN, Jacques. Algumas Reflexões sobre o Ego in Opção Lacaniana, n. 24, jun 1999. Autres Éctits. Paris: Éditions du Seuil, 2001. Écrits. Paris: Éditions du Seuil, 1966. . Le Séminaire I - Les Écrits Techniques de Freud (1953-1954). Paris: Éditions du Seuil, 1975.

. Le Seminaire II - Le moi dans la théorie de Freud et dans la technique de la psychanalyse. Paris: Éditions du Seuil, 1978.

LAPLANCHE; PONTALIS, P.-B. Vocabulaire de la Psychanalyse. Paris : PUF, 2004. 
LEFORT, Claude. Sur une Colone absente - Écrits autor de Merleau-Ponty. Paris: Gallimard, 1978.

LHERMITTE, Jean. L'Image de Notre Corps. Paris: L'Harmattan, 1998.

LUQUET, G.T. O Desenho Infantil. Tradução de Maria Teresa Gonçalves de Azevedo. Porto: Minho, 1969.

MARCEL, Gabriel. Etre et Avoir. Paris: Aubier, 1935.

MADISON, Gary Brent. The Phenomenology of Merleau-Ponty - A Search for the Limits of Consciousness. Ohio: Ohio University Press, 1990.

MERLEAU-PONTY, Maurice. Les Aventures de la Dialectique. Paris: Gallimard, 1955. . Causeries - 1948. Paris: Éditions du Seuil, 2002.

. Éloge de la Philosophie et Autres Essais. Paris: Gallimard, 1983.

.Fenomenologia da Percepção. Tradução de Carlos Alberto Ribeiro de Moura. São Paulo: Martins Fontes, 1999.

. Humanisme et Terreur - Essai sur le Problème Communiste. Paris: Gallimard, 1947.

. L'Institution, la Passivité - Notes de Cours au Collège de France (1954-1955). Paris:

Belin, 2003.

. Merleau-Ponty à la Sorbonne - résumé de cours (1949-1952). Dijon: Cynara, 1988.

. La Nature - Notes de Cours du Collège de France. Paris: Seuil, 1995.

. La Nature ou le monde du silence, Vol VI (BN : 9587). Inédito, 1957.

. Notes de Cours (1959-1961). Paris: Gallimard, 1996.

. Notes de Cours sur l'Origine de la Géométrie de Husserl - suivre de Recherches sur la Phénoménologie de Merleau-Ponty. Paris: PUF, 1998.

. L'Oeil et l'Esprit. Paris: Gallimard, 2004.

. Parcours (1935-1951). Paris: Verdier, 1997.

. Parcours Deux (1951-1961). Paris: Verdier, 2000.

. Phénoménologie de la Perception. Paris: Gallimard, 1967.

. Le Primat de la Perception - et ses Conséquences Philosophiques. Paris: Verdier, 1996.

. La Prose du Monde. Paris: Gallimard, 2004.

. Résumés de Cours - Collège de France (1952-1960). Paris: Gallimard, 1968.

. Sens et Non-Sens. Paris: Gallimard, 2004.

. Signes. Paris: Gallimard, 2000.

. La Structure du Comportement. Paris: Quadrige/PUF, 2002. 
. L'Union de l'Âme et du Corps chez Malebranche, Biran et Bergson. Paris: Vrin, 2002.

. Le Visible et l'Invisible. Paris: Gallimard, 2004.

MOURA, Carlos Alberto Ribeiro. Crítica da Razão Fenomenológica. São Paulo: Nova Stella/USP, 1989.

Racionalidade e Crise. São Paulo: Discurso;UFPR, 2001.

MOUTINHO, Luiz Damon Santos. Razão e experiência - Ensaio sobre Merleau-Ponty. Rio de Janeiro: UNESP, 2006.

MÜLLER, Marcos José. Merleau-Ponty - acerca da expressão. Porto Alegre: EDIPUCRS, 2001.

OGILVIE, Bertrand. Lacan: la formation du concept de sujeit. Paris: PUF, 1987.

OLKOWSKI, Dorothea; MORLEY, James (org). Merleau-Ponty, Interiority and Exteriority, Psychic life and the Word. New York: Suny, 1999.

PAVLOV, I. La psychopathologie et la psychiatrie - Ouvres choisies. Traduit du russe par E. Bronina. Moscou: Zoubovski, 1961.

PEILLON, Vincent. L'Épaisseur du Cogito - Trois Études sur la Philosophie de Maurice Merleau-Ponty. Lastresne: Le Bord de l’Eau, 2004.

PIAGET, Jean. A construção do real na criança. Tradução de Álvaro Cabral. Rio de Janeiro: Zahar Editores, 1975.

O nascimento da inteligência na criança. Tradução de Álvaro Cabral. Rio de Janeiro: Zahar Editores, 1970.

La représentation du monde chez l' enfant. Paris: Presses Universitaires de France, 1947.

Seis estudos de psicologia. Tradução de Maria Magalhães D’ Amorim e Paulo S. Lima Silva. Rio de Janeiro: Forense Universitária, 1980.

PIAGET, Jean; INHLEDER, Bärbel. A psicologia da criança. Tradução de Octavio Mendes Cajado. São Paulo: Difel, 1986.

POLITZER, Georges. Critique des fondements de la psychologie. Paris: PUF, 1968.

. La crise de la psychologie contemporaine. Paris: Éditions Sociales, 1947.

PONTALIS, J.-B. Note sur le Problème de l'Inconscient chez Merleau-Ponty in Les Temps Modernes. Paris, 17o. Année, no. Spécial sur Merleau-Ponty, octobre, 1961.

RICHIR, Marc (org). Merleau-Ponty - phénoménologie et experiences. Paris: Editions Jérôme Millon, 1992. 
SAFATLE, Vladimir. O amor pela superficie: Jacques Lacan e o aparecimento do sujeito descentrado. Tese de mestrado em filosofia apresentada ao Departamento de Filosofia da Universidade de São Paulo, sob a orientação do Prof. Dr. Bento Prado Junior. São Paulo, 1997.

(org.). Um limite tenso - Lacan entre a filosofia e a psicanálise. São Paulo: UNESP, 2003.

. A Paixão do Negativo - Lacan e a dialética. São Paulo: UNESP, 2006.

SARTRE, Jean. L'Être et le Néan - Essai d'Ontologie Phénoménologique. Mesnil-surl’Estrée: Gallimard, 2006.

. A Imaginação. Tradução de Luiz Roberto Salinas Fortes. Rio de Janeiro, 1989.

. L'Imaginaire - Psychologie Phénoménologique de l'Imagination. Paris: Gallimard, 1948.

. Merleau-Ponty Vivant. in Les Temps Modernes. Paris, 17o. Année, no. Spécial sur Merleau-Ponty, octobre, 1961.

. Situations I. Paris: Gallimard, 1947.

SCHILDER, Paul. The Image and Appearance of the Human Body - Studies in the Constructive Energies of the Psyche. New York: International Universities Press, 1950.

SCHMIDT, James. Lordship and Bondage in Merleau-Ponty and Satre in Political Theory Volume 7, Number 2. New York: Sage Publications, May 1979.

. Maurice Merleau-Ponty - Between Phenomenology and Structuralism. Hong Kong: Macmillan Publishers, 1985.

SCHELER, Max. Nature et Formes de la Sympathie - Contribution des Lois de la Vie Émotionnelle. Traduit de l'allemand par M. Lefebvre. Paris : Payot, 1928.

SHEPHERDSON, Charles. Uma libra de Carne - A leitura de Lacan d'O visível e o invisível. Tradução de Ronaldo Manzi Filho. No prelo.

SILVA, Franklin Leopoldo e. Ética e Literatura em Sartre - Ensaios Introdutórios. São Paulo: UNESP, 2004.

. Descartes - A Metafísica da Modernidade. São Paulo: Moderna, 1993.

SILVA-CHARRAK, Clara da. Merleau-Ponty - le Corps et le Sens. Paris: PUF, 2005.

SIMANKE, Richard Theisen. Metapsicologia lacaniana - os anos de formação. São Paulo:

Discurso Editorial; Curitiba: UFPR, 2002.

SPIEGELBERG, Herbert. Phenomenology in Psychology and Psychiatry - An Historical Introduction. Evanston: Northwestren University Press, 1972. 
STERN, Daniel N. The Interpersonal World of the Infant - A View from Psychoanalysis and Developmental Psychology. New York: Basis Books, 1985.

UEXKÜLL, Jacob von. Dos animais e dos homens. Tradução de Alberto Candeias e Aníbal Garcia Pereira. Lisboa: Livros do Brasil, 1988.

WAELHENS, Alphonse de. Une Philosophie de l'Ambiguité - L'Existentialisme de Maurice Merleau-Ponty. Louvain ; Paris : Publications Universitaires de Louvain; Éditions BeatriceNauwelaerts, 1968.

. Situation de Merleau-Ponty in Les Temps Modernes. Paris, 17o. Année, no. Spécial sur Merleau-Ponty, octobre, 1961.

WAHL, Jean. Vers le Concret - Études d'Histoire de la Philosophie Contemporaine. Paris: Vrin, 1932.

WALLON, Henry. A evolução psicológica da criança. Tradução de Cristina Carvalho. Lisboa: Edições 70, 1998.

. L' enfant turbulent - etude sur les retards et les anomalies du developpement moteur et mental. Paris: Presses Universitaires de France, 1984. . Les Origines du Caractère chez l'Enfant. Paris: Quadrige/PUF, 2002. - As origens do pensamento na criança. Tradução de Doris Sanches Pinheiro e Fernanda Alves Braga. São Paulo: Manole, 1989.

WEISS Gail. Body Images - Embodiment as Intercorporeality. New York: Routledge, 1998. WHITESIDE, Kerry. Merleau-Ponty and the Foundation of an Existential Politics. Princeton; New Jersey: Princeton University Press, 1988.

WOLMAN, Benjamin B. Contemporary Theories and Systems in Psychology. New York: Harper \& Row, 1960

YOUNG, Iris Marion. Throwing Like a Girl - A Phenomenology of Feminine Body Comportment, Motility, and Spatiality in ALLEN, Jeffner; YOUNG, Iris Marion. Thinking Muse - Feminism and Modern French Philosophy. Bloomington and Indianapolis: Indiana University Press, 1989.

ZAZZO, René. Henri Wallon - psicologia e marxismo. Tradução de Joaquim Bairrão. Lisboa: Editorial Vega, 1978. . De l' enfant à l' adulte in Le devenir de l'intelligence. Paris: Presses Universitaires de France, 1946. 